\title{
BEYOND ACCIDENT: \\ A MODEL FOR THE COMPENSATION OF WORK- RELATED HARM IN NEW ZEALAND
}

\author{
DAWN DUNCAN
}

A thesis submitted to the Victoria University of Wellington in fulfilment of the requirements for the degree of Doctor of Philosophy

FACULTY OF LAW

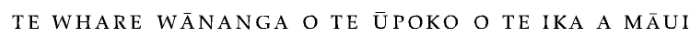

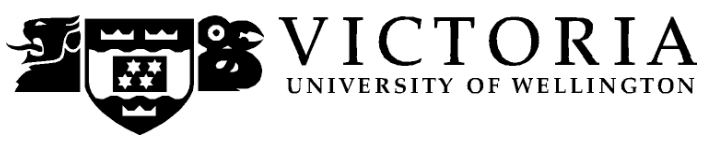


ABSTRACT

ACKNOWLEDGMENTS

CHAPTER ONE: INTRODUCTION 15

I Introduction 15

II Background__ 16

A A difficult history _ 17

B A scheme in need of reform

III Proposing Reforms to Improve Cover and Work Health and Safety

A Problem one: Gaps in cover __ 20

B The consequences of exclusion __ 22

C Problem two: Negative consequences for work health and safety ___ 23

D The relationship between ACC and work health and safety__ 25

E A labour law approach to reform 26

IV Contribution of this Thesis__ 29

CHAPTER TWO: BACKGROUND___ 31

I Introduction _ 31

II ACC and Approaches to Compensating Workers Harmed at Work__ 32

III New Zealand's Workers' Compensation Regime __ 33

IV The Woodhouse Report and the ACC Scheme 35

V The Difficult Decades that Followed___ 38

VI Workers' Compensation or Social Insurance ___ 39

VII A Political Compromise: An Accident Compensation Scheme___ 43

VIII Conclusion _ 44

CHAPTER THREE: AIMS, SCOPE AND METHOD__ 47

I Introduction

II An Introduction to Labour Law__ 48 
III Davidov's Purposive Approach to Labour Law

A Translating Davidov's approach in to a specific method 53

B A note on comparing labour laws across jurisdictions 55

IV Should Reform of the ACC Scheme be thought of as part of Labour Law? 56

V The Labour Law Aims of the Project 59

A Power-based conceptions 61

B Rights-based conceptions 64

C Wrongs-based conceptions 66

D Unequal status and dignity 68

E Summarising the goals for the project 70

VI Improved Health and Safety- The Ends also Justify the Scope 72

A Is ACC reform the best place to seek improvements to worker health and safety?

B Why not seek to address the problems through collective bargaining? 75

C Why not just enact the full Woodhouse Report vision? 77

D Why reject a torts and insurance-based solution? 85

VII Conclusion 88

CHAPTER FOUR: THE PROBLEMS WITH THE CURRENT ACC COVERAGE_91

I Introduction $\quad 91$

II The Current Coverage of Work-Related Health Problems__ 92

A The Occupational Diseases Schedule __ 93

B Section 30 cover of gradual processes, diseases or infections _ 94

C The concept of occupational disease

III Particular Exclusions__ 98

A A particular problem for female-dominated occupations _ 98

B Work-related heart attack or stroke _ 100

C Mental health problems 102 
D An outdated mind/body dualism 103

E Work-related infections

F Gaps as a consequence of the focus on "accident" _ 108

IV The Consequences of the Gaps in Cover 109

A Options for workers with excluded conditions _ 109

B Lack of data 112

C A gender divide in cover 115

D Māori potentially significantly affected___ 118

V Inconsistency with Health and Safety Laws _ 119

A The problem with "accident" for health and safety __ 120

B "Accident" and the HSWA 122

VI Conclusion 124

CHAPTER FIVE: THE URGENT CHALLENGES OF WORK-STRESS-RELATED

HEALTH PROBLEMS 125

I Introduction 125

II The Rise of Stressful Work in New Zealand __ 126

A The Decline of Manufacturing and the Rise of "Services" 127

III Changes to the Organisation and Management of Work _ 130

A The pursuit of employee engagement

B Increased demand for connection 132

C Work intensification

D Digital monitoring and surveillance___ 137

E Increasing flexibility and "precarious" work _ 139

F Economic instability and vulnerability

IV The Parallel Rise of Stress-Related Illness Research _ 145

A What is stress?

B The human stress response 
C Stress and its connection to disease

V Stress and Cardiovascular Diseases

A Stress and heart attack

B Work-stress and cardiovascular diseases

VI Stress and its Connection to Depression

A Stressful environments and depression 156

B Three organizational psychology conceptual models

C The interrelated role of genetics and environment

VII Stress and Musculoskeletal Disorders 161

A Lower back pain and work 162

B A role for genetics 163

C "Natural" deterioration and causation 164

D The complexities of pain 165

E Complex interrelationships 168

VIII Conclusion 169

CHAPTER SIX: DEVELOPING A NEW APPROACH TO CAUSATION 171

I Introduction 171

II The Additional Causal Challenges of Chronic Health Problems 172

A Theories of causation 172

B Some of the additional uncertainties in the evidence 175

C Responding to complexity and uncertainty in the causal evidence 178

III Disciplinary and Cultural Impacts on Narratives 180

A Culturally specific narratives 184

B Māori narratives of disease causation 187

C Politically influenced narratives 190

IV Conclusion 195 
CHAPTER SEVEN: A NEW MODEL FOR THE COMPENSATION OF WORKRELATED HARM

I Introduction 197

II A New Compensation Act 198

A Not an "Accident" Compensation Act 198

B A new title for the Act and a new name for the scheme 201

C New purpose sections 201

D Removal of the Occupational Diseases Schedule 202

E The new Work-Related Harm Part purpose section 205

F New causal test 206

G New terms framing the causal narrative 209

III Intended Operation 211

A Examples of operation 212

Example: Worker C's heart attack 212

Example: Worker D's severe depression 215

Example: Worker E's bad back 217

IV Achieving the Labour Law Goals Set 218

A Addressing the inequalities of bargaining power 218

B Recognising the "wrongs" of poor health and safety 221

C Recognising the rights of workers 221

D Dignity and equity for workers 222

V Conclusion 222

CHAPTER EIGHT: THE PROPOSED NEW ACT 223

I Introduction 223

II Proposed Drafting 224

III Explanation of Proposed Drafting 227

A Proposed "Interpretation" section 227 
B A shift from "accident" to "harm" 227

C A shift from "employee" to "worker" 232

D "Workplace" and "working environment" 234

IV A New Purpose Section for the Part 239

A Recognising the rights of workers harmed through work 239

B Comprehensive, fair and equitable cover $\_240$

C Health, dignity and participation 241

D Improvement of health and safety in New Zealand workplaces _ 242

V A New Test for Cover _ 244

A Caused by, triggered, exacerbated, or significantly contributed to $\_244$

B Allows greater scope for differing cultural meanings of disease __ 248

C Non-exhaustive list__ 248

VI Harm to third parties affected by exposure to a transmitting worker___ 262

VII Other Associated Matters __ 265

A A new Review Panel on Work-Related Harm__ 265

B Costs implications — 267

C Possibility of a fully comprehensive social insurance scheme in future _ 269

VIII Conclusion 270

CHAPTER NINE: CONCLUSION___ 271

I Introduction 271

II The Aims of Reform _ 272

III The Reforms Proposed __ 272

IV Limitations, Opportunities and Next Steps __ 274 
BIBLIOGRAPHY

I Cases

A New Zealand

B Australia 278

II Legislation 278

A New Zealand 278

B Australia 279

C United Kingdom 279

III Regulations 279

IV International Treaties and Conventions 279

V Books 280

A Chapters in Books 285

VI Journal Articles 287

VII Parliamentary and Government Materials 303

VIII Reports 303

IX Dissertations 308

X Internet Resources 308

XI Speeches 310

XII Media Reports 310

XIII Other 311 


\begin{abstract}
This thesis examines the compensation of work-related injuries and illnesses under the Accident Compensation Act 2001 (ACA). It proposes a set of legislative reforms to enable fairer and more equitable access to compensation for workers and improvements to work health and safety. This thesis approaches the development of a model for reform as an endeavour within labour law (rather than welfare or insurance law) and adopts a labour law theoretical framework for analysis.
\end{abstract}

This thesis argues that the current coverage problems are a product of the scheme's unique political history, and starts by outlining the historical origins of the scheme and the political compromises, theoretical tensions, and ideological shifts that have led to the current ACA. It also examines the challenges posed by changes in the nature of work, the workforce, and the ways workers are engaged to perform work. This thesis focusses on the cover of chronic work-related health problems, and, in particular, the complex relationships of causation in work-stress related depression, cardiovascular disease and musculoskeletal conditions. While particular attention is paid to the complexities associated with work-stress-related illness the model proposed is intended to improve the cover of, and data collection on, all work-related health problems in New Zealand.

This thesis proposes a new Act to replace the ACA, with a new structure, new purpose section and definitions, new cover test, and the creation of a new work-health review panel. The reform proposal is intended to achieve fairer coverage of work-related health problems, and contribute to improvements in work health and safety in New Zealand, ensuring compensation, treatment and rehabilitation is available to the increasing numbers of workers affected, and making those conditions more visible within the workplace injury and illness statistics. 


\section{ACKNOWLEDGMENTS}

I would like to thank my supervisors, Gordon Anderson and Bill Atkin, for their helpful guidance, review and advice in the preparation of this thesis.

I would like to acknowledge the officials from the Ministry of Business, Innovation and Employment and WorkSafe New Zealand, the New Zealand Council of Trade Unions, the Coalition for ACC Futures and a number of lawyers and health professionals who have offered opportunities to share my ideas and provided feedback.

A particular thank you to my public health colleagues who reviewed the use of the medical research in this thesis. 


\title{
CHAPTER ONE: INTRODUCTION
}

\author{
A Reform Proposal to ensure a Better Scheme, not just a Bigger One.
}

\section{Introduction}

This thesis examines the compensation of work-related injuries and illnesses under the Accident Compensation Act 2001 (ACA). It proposes a set of legislative reforms to enable fairer and more equitable access to compensation for workers and improvements to work health and safety. There have been many calls to expand and reform the Accident Compensation Corporation scheme (ACC) over its fifty-year history. Unlike previous treatments, this thesis focuses solely on work-related injuries and illnesses, making improved work health and safety a primary goal for the reforms proposed. This narrower scope allows for the unique context of work to be recognised and to drive the development of reforms. Work has changed a great deal in the last fifty years, and particular attention is paid to the health effects of psychosocial hazards and the rise of chronic work-stress-related illnesses. The thesis adopts a purposive labour law approach, starting with the assumption that such injuries and illnesses are not "accidents" but arise from the social and economic relations of work. A new approach and structure for the legislation is proposed, and the drafting for a new set of work-related harm cover provisions is provided. 


\section{Background}

In New Zealand, compensation for work-related injury and illness is provided primarily through ACC. ACC provides cover to people that suffer an "accident" as defined in section 25 , and to others with certain personal injuries resulting from work, vehicle collisions, sexual assault or medical negligence. The ACC scheme has become a central feature of the New Zealand's legal landscape and has a significant impact on many aspects of daily life, including the management of the workplace. The ACC scheme is run by the New Zealand Government and funded in a combination of ways, including levies on employers and the self-employed for work-related health problems, a general levy on earners of 1.21 per cent to cover non-work injuries, a vehicle licensing fee and a levy on petrol for motor vehicle accidents, and also funding from the general taxation pool.

Where a person has cover under the ACC scheme, they are generally entitled to treatment costs (e.g. surgery, drugs, an ambulance or hospital care) and compensation for loss of weekly earnings. Earnings compensation is paid at the rate of 80 per cent of pre-incapacity weekly earnings after the first week, with the first week paid for by the employer. ACC also provides vocational rehabilitation and return to work planning, support, and assessment, modifications to a person's home or car and, depending on the impairment, other benefits such as a lump-sum payment. Where a person has ACC cover for their personal injury, they lose the right to sue for compensatory damages. ${ }^{1}$ There is no ability to opt-out of ACC cover and pursue a common-law claim, but workers can sue if their injury falls outside the coverage of the scheme, as discussed further in Chapter Four.

${ }^{1}$ ACA, s 317(1). Position reaffirmed recently in McGougan and Dingle v Depuy International Ltd [2016] NZHC 2511. It is possible to sue for exemplary and nominal damages, see Couch v Attorney-General (No 2) [2010] NZSC 27, [2010] 3 NZLR 149 and Re Chase [1989] 1 NZLR 325 (CA), but the effect of the ACC scheme has largely been the elimination of claims for compensatory damages for personal injury. 


\section{A A difficult history}

The cover of work-related injury and illness under the scheme has a long and complicated history. The ACC scheme arose from the 1967 Report of the Royal Commission of Inquiry into Personal Injury in New Zealand, chaired by the then Justice Woodhouse, commonly referred to as the Woodhouse Report. ${ }^{2}$ Prior to the introduction of ACC, New Zealand had a workers' compensation regime, based originally on the Workmen's Compensation Act 1897 (UK) and operating in a similar way to the workers' compensation schemes in Australia at the time. The Royal Commission went further than its brief to recommend reforms to workers' compensation, and proposed a radical and universal social insurance scheme that would eventually provide for "all the hazards of modern living," regardless of cause. ${ }^{3}$ Such a scheme was beyond the appetites of the National Party Government in the early 1970s, and to ensure the political success of the proposal, the scheme was limited to "accidents" and the pre-existing cover of occupational diseases. ${ }^{4}$

The first Accident Compensation Act 1972 was considered by law makers at the time as a temporary political compromise and "a step in the right direction." The ACC scheme replaced the Workers' Compensation Act 1956 and extended cover beyond just those harms "arising out of, or in the course of, employment", to a range of "accidents" unrelated to work. ${ }^{6}$ While this was a significant expansion in cover, it was less than envisioned by Woodhouse and fellow reformers. At the time of enactment, it was declared by the Opposition that: ${ }^{7}$

....the Government has blinkered boldness with caution and has converted a simple and grand design conceived by the Woodhouse commissioners in to a complex compromise, and, as a result, has dishonoured a prophet in his own country.

\footnotetext{
${ }^{2}$ Royal Commission of Inquiry into Personal Injury in New Zealand Compensation for Personal Injury in New Zealand: Report of the Royal Commission of Inquiry (Government Printer, Wellington, 1967)

(Woodhouse Report).

3 The Woodhouse Report.

4 The Woodhouse Report, at 3.

5 (3 October 1972) 381 NZPD 2983 (Accident Compensation Bill- David Thomson).

6 Workers' Compensation Act 1956, s3.

7 (3 October 1972) 381 NZPD 2985 (Accident Compensation Bill- David Thomson).
} 
The Opposition promised that when returned to power it would "introduce not only the letter of the Woodhouse [R]eport but also the spirit and concept behind it." 8 An attempt was made by the Labour Government in 1989, just prior to a general election, which they lost. The incoming National Government rejected the proposal, eventually privatising the ACC scheme in the late 1990s. The 1999 election saw Labour return to power, and the return of ACC to public ownership. This was followed by a period of hesitant ad hoc repairs, and then by decades of neglect. As discussed further in Chapter Two, the full vision of the Woodhouse Report was not enacted, and the original "temporary" compromises remained in later iterations of the legislation.

\section{B A scheme in need of reform}

The ACC scheme is in need of major reform. Between 2014 and 2017, five critical independent reports were released, highlighting major problems in the operation of the ACC scheme and the treatment of claimants. ${ }^{9}$ Concerns were also raised in a 2018 report by the OECD, which described the current cover provisions as creating "an inequitable divide." ${ }^{10}$ In 2017, the Coalition of ACC Futures, a lobby group comprising unions, healthcare providers, academics and claimant advocates, was reconvened to place pressure on the Government to address the issues, ${ }^{11}$ and there has been increasing media attention highlighting the gaps in ACC cover and the consequences of exclusion. ${ }^{12}$ In 2018, Sir

\footnotetext{
${ }^{8}$ (3 October 1972) 381 NZPD 3023 (Accident Compensation Bill- Arthur Faulkner).

${ }^{9}$ Acclaim Otago (Inc) Adopting issues: An interim report to the United Nations Committee on the Convention on the Rights of Persons with Disabilities (February, 2014), Acclaim Otago (Inc)

Understanding the Problem: An analysis of ACC appeals processes to identify barriers to access to justice for injured New Zealanders (July, 2015), Miriam Dean Independent Review of the Acclaim Otago (Inc) July 2015 Report in to Accident Compensation disputes processes (May 2016); and Warren Forster, Tom Barraclough and Tiho Mijatov Solving the problem: Causation, transparency and access to justice in New Zealand's personal injury system (May 2017).

${ }^{10}$ OECD Mental Health and Work: New Zealand Mental Health and Work (OECD Publishing, Paris, 2018), at 16.

${ }^{11}$ Information on the Coalition of ACC Futures including its manifesto can be found on the ACC Futures website $<$ https://accfutures.org.nz $>$

${ }^{12}$ See Veronica Schmidt "Why ACC is turning away traumatised mosque survivors" Radio New Zealand (14 May $2019<$ https://www.rnz.co.nz/news/in-depth/389140/why-acc-is-turning-away-traumatised-
} 
Geoffrey Palmer used the Sir Owen Woodhouse Memorial Lecture to call for ACC reform to finish the "unfinished business" of comprehensive social insurance. ${ }^{13}$

Responding to calls for reform, a significant piece of research is currently being carried out by Warren Forster, exploring options for funding an expanded scheme to cover to a wider range of non-work illnesses and disabilities. ${ }^{14}$ This thesis takes a different approach to that of Forster, and that originally advanced by Woodhouse, focusing on work-related harm and the need for improved work health and safety. This more-focused scope allows for reforms to be designed to impact positively on work health and safety, ultimately reducing the rates of work-related injury and illness suffered. The proposed reforms have been developed to enable the achievement of health and safety goals in either a similar-sized scheme to that currently in operation, or as part of a substantially expanded social insurance scheme, should Forster and Palmer succeed in convincing the Government to introduce one.

\section{Proposing Reforms to Improve Cover and Work Health and Safety}

The thesis aims to develop a proposal for reforms that solves two related problems. First, under the current ACA many people suffering work-related injuries and illnesses are unfairly excluded from cover, and as a result from the treatment costs, earnings-related compensation and rehabilitation provided. These exclusions can result in significant hardships for workers and their families, and have a disproportionate effect on workers in female-dominated occupations, on Māori workers, and people in precarious work. Second,

mosque-survivors>; Matt Shand "Terminally ill father made choice to die in protest against ACC treatment" Stuff (31 May 2019) <https://www.stuff.co.nz/national/health/113068517/terminally-ill-fathermade-choice-to-die-in-protest-against-acc-treatment>; Ruby Macandrew "Dying long after the flames are out: Firefighters call on lawmakers to extend ACC cover to occupational cancers" Stuff (23 May 2019) $<$ https://www.stuff.co.nz/national/health/1 12937174/dying-long-after-the-flames-are-out-firefighters-callon-lawmakers-to-extend-acc-to-cover-occupational-cancers>

${ }^{13}$ Geoffrey Palmer "A retrospective on the Woodhouse Report: The vision, the performance, and the future" Sir Owen Woodhouse Memorial Lecture, Victoria University of Wellington (September 2018).

${ }^{14}$ This research is still ongoing at the time of submission and is yet to report on its recommendations. Details of the project can be found on the Law Foundation website $<$ https://www.lawfoundation.org.nz/?p=8474> 
the gaps in cover and compromised operation of the ACC scheme undermine work health and safety in New Zealand, rendering important work-related health conditions invisible to policy-makers and the regulator, influencing and reinforcing poor health and safety practices, and making it more difficult to respond to changing patterns of work.

\section{A Problem one: Gaps in cover}

While the drafting problems are discussed in greater detail in Chapter Four, to summarise, the legislation adopts an "accidents plus exceptions" model, which results in the exclusion of many work-related health problems. Cover is provided where injuries meet the definition of accident, defined as "a specific event or a series of events, other than a gradual process" that involves the: ${ }^{15}$

....application of a force (including gravity), or resistance, external to the human body; or involves the sudden movement of the body to avoid a force (including gravity), or resistance, external to the body; or involves a twisting movement of the body.

This definition covers work-related slips, trips and falls, many lifting and manual handling injuries, machinery and tool related injuries and some situations of poisoning, burns, or exposure to radiation or extremes of temperature. ${ }^{16}$

Cover is also provided for some work-related health conditions that fall outside this definition, in sections 21B, 28 and 30, and the Occupational Diseases Schedule. As was the case in the original 1972 legislation, the ACA extends cover to "occupational diseases" (the term used in the Act) in two ways. First, there is a schedule of occupational diseases which includes the "classic" occupational diseases of the $20^{\text {th }}$ century, such as lead or arsenic poisoning, silicosis, a limited range of zoonosis diseases (from animals and carcasses) and a limited range of diseases from inhaling toxic substance containing dusts or fumes. Second, section 30 provides cover to a range of gradual processes, diseases or

\footnotetext{
${ }^{15}$ Section 25(1)(a).

${ }^{16}$ Section 25(1)(b)-(e).
} 
infections that are not included in the Schedule, where the claimant can meet its four-part test.

Section 30 is formulated narrowly, excluding many workers in newer or less researched areas of work and those performing tasks that are also present in their non-work lives (e.g. caring for children). Stress-related illnesses are explicitly excluded from section 30, leaving large numbers of workers with these health conditions excluded from cover. There is, for example, no cover for stress-related burn-out, depression or anxiety, nor for the exacerbation of physical health problems like high blood pressure, back pain or autoimmune conditions. As discussed further in Chapter Four, the ACA provides cover for some situations of single incident mental trauma under section $21 \mathrm{~B}$, but is very limited in scope, excluding most victims of workplace bullying, occupational violence or harassment and traumatic-stress-conditions which cannot be attributed to an unusual one-off event. ${ }^{17}$

The ACA also provides cover for heart attack or stroke occurring in all but medically impossible circumstances. Section 28(3) provides cover where a person suffers a "cardiovascular or cerebrovascular episode caused by physical effort or physical strain," where it is "abnormal in application or excessive in intensity for the person." There is no cover where the condition is triggered by "non-physical stress" or where there is any evidence of pre-existing cardiovascular disease, which as discussed further in Chapter Five, will exclude almost every incidence.

While developing a proposal to improve the cover and prevention of all work-related injuries and illnesses, this thesis focuses particularly on work-stress-related illnesses like depression, cardiovascular disease and chronic musculoskeletal pain. Discussed further in Chapter Five, these conditions are predicted to become the biggest sources of work-related incapacity in countries like New Zealand, with the growth of stress-related illnesses mirroring the growth of stressful work. Increasing work flexibility and "precarity", work intensification, increased worker surveillance, hyper-connectivity and increasingly

${ }^{17}$ Case law on this section is discussed in detail in Chapter Four. 
frequent organisational restructuring have all been shown to increase worker stress and to result in worker health problems. ${ }^{18}$ These conditions also present some of the biggest challenges to a future compensation scheme and to health and safety prevention activities, due to the more complex causal relationships between the hazards of work and the development of the conditions. This thesis argues that ensuring the compensation scheme can respond to these conditions is essential for ACC to be able to meet the needs of New Zealand workers in future.

\section{B The consequences of exclusion}

The exclusion of these health conditions often leaves workers without adequate and appropriate treatment, financial support or access to rehabilitation services. While excluded workers can sue for compensation, this is rarely an equivalent option to ACC cover. Unlike the "no-fault" ACC scheme, workers must prove their employer failed to provide safe and healthy work, unjustifiably, in breach of contract, or in breach of the duties imposed by the Health and Safety at Work Act 2015 (HSWA). The New Zealand Court of Appeal in the leading case of Attorney-General $v$ Gilbert described this requirement as posing "formidable obstacles" to claimants. ${ }^{19}$ Where workers have health problems that are causally complex, or have long lead-in times, they face significant evidentiary hurdles. They also bear the financial and emotional costs of pursuing a claim, which is a particular barrier to someone with a stress-related health problem and no income. ${ }^{20}$ If successful in proceedings, the remedies available are typically less than provided under the ACC scheme, and not designed for ongoing treatment, income support, rehabilitation or enabling a return to work.

\footnotetext{
${ }^{18}$ This research is reviewed in detail in Chapter Five.

${ }^{19}$ Attorney-General v Gilbert [2002] 2 NZLR 342, at [87].

${ }^{20}$ While such cases are typically resolved through mediated settlement, the case of Attorney-General $v$ Gilbert, cited above, highlights the potential for defendants with deep pockets to protract matters for many years, increasing the financial costs and worsening the health of the plaintiffs.
} 
The options for legal proceedings also depend on the legal relationship of the worker to the person engaging them, with employees generally having better prospects of obtaining compensation than other workers. This thesis uses the term "worker" as defined in the HSWA to mean "an individual who carries out work in any capacity" for a Person Conducting a Business or Undertaking (PCBU). This definition includes independent contractors and captures both the ACC categories of "employee' and "self-employed person". Where workers cannot bring proceedings or are unsuccessful in their claim, they have only private insurance (if they have it) or the benefit system to fall back on. There has been research in to the differences in outcomes between people with the same level of incapacity covered by ACC and those accessing a benefit. This research indicates that those without ACC cover have "considerably poorer socio-economic outcomes", do not return to work as early, and are the "most vulnerable for decline into poverty and ill health." 21

There is also a discernible pattern in who is excluded from cover. As discussed further in Chapter Five, the work performed in New Zealand has changed a great deal since the 1960s, with greater numbers of workers performing stressful or mentally and emotionally hazardous work. Although there are no reliable New Zealand statistics on the number of workers excluded (for reasons discussed below), the international literature highlights that the gaps in ACC cover are likely to disproportionately exclude workers in femaledominated occupations such as teaching, nursing, aged-care and administration. ${ }^{22}$ A recent report by the OECD also concluded that Māori were particularly at risk, and disproportionately affected by the gaps in ACC coverage. ${ }^{23}$

\section{Problem two: Negative consequences for work health and safety}

As discussed further in Chapter Three, the ultimate goal for the law reform proposal is the improvement of work health and safety. The ACC scheme is a significant, but sometimes

\footnotetext{
${ }^{21} \mathrm{~S}$ McAllister, S Derret, R Audus, P Herbison and C "Do different types of financial support after illness or injury affect socio-economic outcomes? A natural experiment in New Zealand" (2013) 85 SSAM 93.

${ }^{22}$ This research is discussed in detail in Chapters Four and Five.

${ }^{23} \mathrm{OECD}$, above at $\mathrm{n} 10$.
} 
overlooked, part of New Zealand's occupational health and safety regime, with a bigger impact on daily work health and safety practices than many people think. Its "primary function" under statute is to "reduce the incidence and severity of personal injury" and to provide "a framework for the collection, coordination, and analysis of injury related information." ${ }^{24}$ In New Zealand, work-related harm statistics come almost exclusively from ACC administrative data, meaning where there is no cover there is no data. This lack of statistical information renders many chronic health problems invisible to policy makers and enforcement agencies and this has a negative flow-on effect for health and safety in many industries. The ACC scheme also interacts with health and safety activities at a workplace level, informing incident reporting, the information provided to health and safety representatives, committees and unions, reporting on HSWA due diligence obligations and the behaviours of health practitioners who are funded through the scheme.

New Zealand has a long history of ignoring the chronic health effects of work, many of which are excluded from ACC cover. In 2008, the National Occupational Health and Safety Advisory Committee (NOHSAC) technical report concluded that New Zealand's response is less favourable than in comparable countries, and results in injustice, reduced rehabilitation and return to work prospects, inappropriate and delayed interventions, increased costs to public health, and a lack of reporting and prevention activity. ${ }^{25}$ In the Occupational Health Action Plan, WorkSafe New Zealand (WorkSafe) acknowledges that "workplace exposure to identified health hazards often ends up as a 'poor cousin' to injury prevention and management of safety hazards." 26 The "accident" focus of the ACC scheme contributes to the accident focus of work health and safety activities.

Despite recognising the problems, successive governments have decided not to address the issues due to "cost implications" and "policy difficulties."27 This pattern sadly continued

\footnotetext{
${ }^{24}$ Accident Compensation Act 2001, s3.

${ }^{25}$ Allen and Clarke National Occupational Health and Safety Advisory Committee Technical Report to Government No 11 Defining Work-Related Harm: Implications for Diagnosis, Rehabilitation, Compensation and Prevention (NOHSAC, 2009).

${ }^{26}$ Department of Labour Occupational Health Action Plan to 2013: Workplace Health and Safety Strategy for New Zealand to 2015 (Originally issued December 2011 but revised), at 5.

${ }^{27}$ NOSHAC Technical Report, above, at n 25.
} 
in the Working Safer reforms, with occupational diseases excluded from the current Working Safer national targets because this area is "too difficult to monitor." 28 In Healthy Work: A Strategic Plan for Work-Related Health 2016-2026, WorkSafe acknowledges the failure "to adequately address work-related health risks and the harm associated with them". ${ }^{29}$ This document recognises that work-related health problems are having an "even greater impact on our country ... than acute work-related injuries". ${ }^{30}$ While this recognition of the problem by WorkSafe is heartening, the regulator is unlikely to be able to achieve their work-related health goals without data on these conditions, and comprehensive usable data is unlikely be collected without reform to the ACC scheme. The reforms proposed in this thesis are intended to ensure fair and equitable ACC cover is available to those workers affected, and also make chronic work-related health problems more visible within the injury and illness statistics, allowing for better policy and enforcement responses to be developed.

\section{$D$ The relationship between $A C C$ and work health and safety}

This thesis argues that the ACA and the HSWA should operate as a consistent and coordinated regulatory response to the health impacts of work, and as part of the wider regulation of working conditions. The HSWA was enacted to address New Zealand's poor health and safety record, highlighted in the 2012 Report of the Royal Commission in to the Pike River Coal Mine Tragedy, ${ }^{31}$ and the subsequent Report of the Independent Taskforce on Work Health and Safety. ${ }^{32}$ Based on the Australian Model Work Health and Safety laws,

\footnotetext{
${ }^{28}$ Ministry of Business, Innovation and Employment (MBIE) Working Safer: Reducing Work-Related Fatalities and Serious Injury by 2020: Progress Toward the Target (March 2015), at 20.

${ }^{29}$ WorkSafe New Zealand Healthy Work: A Strategic Plan for Work-Related Health 2016-2026 (Worksafe, August 2016), at 6.

${ }^{30}$ Above.

${ }^{31}$ Royal Commission on the Pike River Coal Mine Tragedy Report of the Royal Commission on the Pike River Coal Mine Tragedy (October 2012). (Pike River Report)

${ }^{32}$ Independent Taskforce on Workplace Health and Safety The Report of the Independent Taskforce on Workplace Health and Safety: He Korowai Whakaruruhau (April 2013). (Independent Taskforce Report) 
the HSWA formed part of the Working Safer Reform Package, ${ }^{33}$ which included greater powers for the regulator, tougher penalties, and the establishment of a national target to reduce serious injuries and fatalities. ${ }^{34}$ While the new HSWA provisions are an improvement, they do little to address New Zealand's systemic failures in responding to chronic work-related health conditions. The Independent Taskforce described this as the country's "tragic paradox": 35

While New Zealand's acute harm and workplace safety statistics are woeful and rightly attract considerable attention, the much more damaging occupational health impacts of the workplace go almost completely under the radar.

In addition to high rates of death and physical injury, an estimated 600-900 New Zealand workers die from occupational diseases each year, with tens of thousands more people suffering incapacitating work-related health conditions. ${ }^{36}$ This thesis focuses on these chronic health impacts presently going under the radar, arguing that an effective health and safety response requires an integrated and well-designed compensation system. The ACA can be viewed as the often neglected "other half" of New Zealand's work health and safety laws, which if not oriented towards improving health and safety can operate to undermine it. This view is argued in Chapter Three to be the most consistent with the labour law approach adopted and the goals for the reform project.

\section{E A labour law approach to reform}

Unlike previous calls for reform, this project is approached as one within labour law, allowing for the social and economic conditions of work and the rights of workers to inform the project goals and the development of the reform proposals. Labour law, as a theoretical

\footnotetext{
${ }^{33}$ Ministry of Business, Innovation and Employment (MBIE) Working Safer: Blueprint for New Zealand's Health and Safety System (August 2013).

${ }^{34}$ Ministry of Business, Innovation and Employment (MBIE) Working Safer: Reducing Work-Related Fatalities and Serious Injury by 2020: Progress Toward the Target (March 2015).

${ }^{35}$ Independent Taskforce on Workplace Health and Safety, above n 32, at 16.

${ }^{36}$ Exact figures unknown for reasons discussed further in Chapter Four. This number is the WorkSafe New Zealand estimate, as reported in WorkSafe New Zealand, above at n 29, at 6.
} 
approach, is different to employment law, reflecting a distinct set of assumptions and normative claims. Labour law is described as being "the combination of subject matter and purpose" 37 with the goal of "securing a more just working relationship for the worker." 38 The aims of the project (improving coverage and work health and safety) align better with the aims of labour law than with private insurance (efficient loss spreading) or social welfare (social contract between citizens and state). Chapter Two introduces these competing theoretical approaches to compensation and explains how each has impacted on the ACC scheme. Chapter Three then explains why the project of reform is approached as one within labour law, arguing that the theoretical basis for the claim to compensation should drive the design of the scheme.

This thesis draws on the work of Guy Davidov in A Purposive Approach to Labour Law, adopting a purposive method to the project of law reform. ${ }^{39}$ Davidov's approach is translated in to a specific three-stage method for the thesis. Stage One, contained in Chapters Two and Three, involves an examination of the theoretical approaches and the framing of goals for the project. Davidov's approach starts with a principles-based analysis of the goals sought. Essentially, the question of "why" workers should receive compensation becomes the driving direction for determining "how" workers should receive compensation. While all three theoretical approaches conclude that there should be compensation available for workers, they differ in the reasons advanced for why, and these differences impact on work health and safety.

Applying a labour law approach, and reflecting the labour law literature, the ACC scheme should be designed to play a role in addressing the inequalities of bargaining power, preventing the wrongs done to workers through poor health and safety, advancing workers' rights to safe and healthy work, and ensuring equity and dignity for workers injured or

\footnotetext{
${ }^{37}$ John Howe "The Broad Idea of Labour Law: Industrial Policy, Labour Market Regulation, and Decent Work" in Guy Davidov and Brian Langille, The Idea of Labour Law (Oxford University Press, Oxford, 2011), at 295.

${ }^{38}$ Kahn-Freund's articulation of labour law in Explanatory Memorandum in Regard to New Protection, Commonwealth Parliamentary Papers, referred to by Howe, above, at n 37.

${ }^{39}$ Guy Davidov A Purposive Approach to Labour Law (Oxford University Press, Oxford, 2016). 
made ill. The purposive approach starts with an analysis and articulation of the goals sought, and then seeks to develop the legislative means with which to achieve those goals. Davidov claims that "the main problem... lies in the mismatch between goals and means". ${ }^{40}$ For Davidov, taking a "purposive approach" will "restore the connection between labour laws and the goals behind them."41

This reconnection between ends and means is particularly important given the peculiar political history of the ACC scheme, and the challenges posed by changing patterns of work. As is set out in Chapter Two, the problems in the current legislation can be understood as stemming from a politically compromised purpose and the lack of clear principle for determining the boundary lines of cover. This thesis advances the view that it is clarity in principle that is needed to address the existing problems and also provides the scheme the best prospects of responding to changing patterns of work and increasing evidential complexity in the causal relationships between work and health.

To achieve these ends, and develop a reform proposal able to contribute to work health and safety, the project starts with the assumption that work-related injuries and illnesses arise from the social and economic conditions of work, are influenced by power and control, and are not "accidents," the product of apathy ${ }^{42}$ or the "inevitable materialisation of risks inherent in production." ${ }^{33}$ In contrast to the Woodhouse Report, health conditions resulting from work are viewed as very different to other types of injury and illness, requiring a different legal response.

Stage Two of the method, contained in Chapters Four and Five, provides an analysis of the problems as against the goals identified. Chapter Four examines the cover problems in the current ACA and explains the negative consequences for work health and safety (briefly

\footnotetext{
${ }^{40}$ Above, at 2.

${ }^{41}$ At 4.

${ }^{42}$ Alfred Robens (Chair) Report of the Committee on Safety and Health at Work (HMSO, London, 1972). (Robens Report)

${ }^{43}$ Harry Glasbeek "Occupational Health and Safety Law: Criminal Law as a Political Tool" (1998) 11 AJLL 95, at 99.
} 
outlined above). Chapter Five then looks to the future of the scheme, examining the rise in stressful work and the parallel rise in stress-related illnesses, which any future compensation scheme will need to address. This problem analysis provides an understanding of the relationships between work and health to inform the development of a new approach to causation.

Stage Three, contained in Chapters Six, Seven and Eight, presents a model of reform to achieve the goals identified. Chapter Six analyses theories of causation further, then Chapter Seven proposes a new approach to causation and advocates for the scheme to move beyond the language and assumptions of "accident." Chapter Seven proposes a new Act with a greater focus on prevention and a new structure that allows for the unique circumstances of work-related harm to be acknowledged within a scheme of wider coverage. The proposed new Act is also structured to allow for the incremental expansion of the scheme to new categories of cover, creating a mechanism for the realisation of the Woodhouse Report vision without undermining health and safety. Chapter Eight contains the drafting for a dedicated Part in the proposed Act. The new Work-Related Harm Part contains a new purpose section, definitions and test for cover that reflect the labour law literature and health and safety goals. The new test is accompanied by an indicative list of hazards, creating a presumption for causal connection, shifting the focus from diagnostic criteria to the conditions of work, and influencing data collection and the behaviour of actors interacting with the scheme.

\section{Contribution of this Thesis}

Unlike previous examinations of the ACC scheme, this thesis takes a labour law approach and starts with a focus on health and safety and the prevention functions of the scheme. This thesis has been written first and foremost with the aim of finding a practical and implementable proposal to reform the compensation of work-related injury and illness in New Zealand. It argues that the work-related harm cover provisions of the ACC scheme should operate as part of the wider regulation of work and working conditions, with the 
primary goals of improving the conditions of work, supporting the better operation of health and safety laws and ensuring equitable care and compensation for workers harmed. The proposal advances a new approach to causation, a new structure for the Act, and a set of drafted legislative provisions. This thesis is also intended to contribute to wider policy debates in New Zealand on the regulation of work, health and safety, and the future of social welfare. Finally, the thesis contributes to the academic literature through its examination and application of Davidov's 2016 purposive labour law method to health and safety and workers' compensation. 


\title{
CHAPTER TWO: BACKGROUND
}

\author{
The Origins and Fundamental Theoretical Tensions of the ACC Scheme
}

\section{Introduction}

It has been 50 years since the Woodhouse Report was published calling for a radical community level response to the many misfortunes befalling New Zealanders. The Woodhouse Report has been described as a "monument" in New Zealand legal history, praised for both its principles and elegance, ${ }^{44}$ and has become a central feature of the social and legal landscape. While the scheme has undoubtedly been a real gain to working people injured outside of work, these wider gains can be seen as coming at the expense of its workers' compensation functions in the decades that followed. The decades following the introduction of the ACC scheme have seen large holes in the cover of work-related health conditions emerge, with the ideological shifts of the 1990s undermining some parts of the scheme, and other parts left to fall behind medical thinking, resulting in obsolescence or absurdity. This chapter provides a brief historical and theoretical background to the research project, providing an overview of the history of the ACC scheme and the key theoretical tensions at the heart of the cover provisions. This then leads to a wider discussion of the theoretical framework underpinning the thesis in Chapter Three and a more detailed examination of the problems in Chapters Four and Five.

\footnotetext{
${ }^{44}$ Ted Thomas "Tribute to Sir Owen Woodhouse" speech given at Accident Compensation: Forty Years on - a Celebration of the Woodhouse Report: "Compensation for Personal Injury in New Zealand. Report of the Royal Commission of Inquiry", University of Auckland (13 December 2007).
} 


\section{ACC and Approaches to Compensating Workers Harmed at Work}

While the ACC scheme is unique to New Zealand, the problem of compensating workers is not. "Compensation for injury and disease arising out of employment is guaranteed by some form of government-mandated insurance (at least nominally) in virtually all nations," with legal responses to compensation falling within three broad categories. ${ }^{45}$ Each of the three approaches starts from a set of fundamentally different assumptions of what ought to be compensated, why, and by whom. The current New Zealand ACC scheme, contrary to the intention of its proponents, comprises a combination of all three of these approaches.

The first approach can be called the "common law and private insurance" model. This model generally requires employers to maintain liability insurance against worker claims. Workers can pursue their claims as a matter of private insurance cover and/or sue in tort. Various versions of this model can be seen in the United Kingdom (UK) and in many states of the United States of America (US). ${ }^{46}$ This model had a significant influence on ACC from 1991 to $2001 .{ }^{47}$

The second approach, followed by countries such as Canada and Australia, can be described as the "workers' compensation scheme" model. This involves state run compensation regimes that operate on a 'no-fault' basis, requiring contributions from employers and workers and either removing, or limiting, common law rights to sue. ${ }^{48} \mathrm{New}$

\footnotetext{
${ }^{45}$ Robert W Klein and Gregory Krohm “Alternative funding mechanisms for workers' compensation: An international comparison" (2006) 59(4) International Social Security Review 3, at 3.

${ }^{46}$ See discussion of the Employer's Liability (Compulsory Insurance) Act 1969 (UK) in Brenda Barrett and David Lewis “Is the Employer's Liability (Compulsory Insurance) Act 1969 Fit for Purpose?” (2016) 45(4) ILJ 503. See also Terence G Ison "Reflections on the State of Workers' Compensation and Occupational Health and Safety in the United States of America and Canada" (2015) 47(1) Compensation and Benefits Review 27 for a historical overview of the regimes in the United States of America and Canada.

${ }^{47}$ See William Birch Accident Compensation: A Fairer Scheme (Government Printer, Wellington, 1991).

${ }^{48}$ See Kevin Purse "The evolution of workers' compensation policy in Australia” (2005) 14(1) Health Sociology Review 8 and Mark A Robinson Accident compensation in Australia: No fault schemes (Legal Books, Sydney, 1987) for a historical discussion of the Australian scheme. See also Terence G Ison "A historical perspective on contemporary challenges in workers' compensation" (1996) 34 Osgoode Hall L J 807.
} 
Zealand had a workers' compensation regime from 1900 to 1972 similar to that in Australia and Canada. Elements of this scheme were adopted in to the 1972 legislation and remain in the provisions for work-related injury, set out further in Chapter Four.

Third, some countries incorporate worker claims within a "social insurance" model. Within this model social insurance is "a fundamental right and entitlement of citizenship" 49 and benefits are distributed without regard to contribution, economic circumstances or fault. Within the social insurance model there is no need for a distinct system for the compensation of workers. This model was what the authors of the Woodhouse Report had in mind. ${ }^{50}$

\section{New Zealand's Workers' Compensation Regime}

From 1900, New Zealand had a workers' compensation regime, originally based on the English Workmen's Compensation Act 1897, and similar in scope to that in Australia and Canada. ${ }^{51}$ Workers' compensation schemes emerged from the "human carnage" of the industrial revolution. ${ }^{52}$ While the law had previously recognised the legal duty of master to servant, it offered little practical assistance to injured workers, with few cases able to get past the "unholy trinity of defences" even if the money to bring a case could be raised..$^{53}$

\footnotetext{
${ }^{49}$ Klein and Krohm, above at $\mathrm{n} 45$, at 7.

${ }^{50}$ See Geoffrey Palmer Compensation for incapacity: A study of law and social change in New Zealand and Australia (Oxford University Press, Wellington, 1979.

${ }^{51}$ The New Zealand Workers' Compensation for Accidents Act 1900, like the early legislation in Australia, was based on the English Workmen's Compensation Act 1897 (UK).

${ }^{52}$ Kevin Purse and Robert Guthrie "Workers Compensation Policy in Australia: New Challenges for a New Government" (2008) JOALAP 99. See also Hazel Armstrong Blood on the Coal: The Origins and Future of New Zealand's Accident Compensation Scheme (Trade Union History Project, Wellington, 2008); and Gregory Guyton “A brief history of workers' compensation” 19 IOJ 106.

${ }^{53}$ The "unholy trinity of defences" were contributory negligence, the fellow servant rule, and voluntary assumption of risk. These operated to defeat claims where the individual or any other worker was in any way responsible for the injury, or where workers had agreed to the risk in some way, such as signing their employment contracts. See Chapter 2 of Richard Johnstone, Elizabeth Bluff and Alan Clayton Work Health and Safety Law and Policy ( $3^{\text {rd }}$ ed, Thompson Reuters, New South Wales, 2009), for discussion of the early development of the law regulating work-related injury, disease and death.
} 
Workers' compensation was part of the early reform agenda of organised labour, with compensation forming part of the bargain over the terms and conditions of work and wider activism for industrial relations law reform. The early workers' compensation schemes were set up and operated by friendly societies. Contributions were made by employees, and then later employers eager to avoid potential liability, ${ }^{54}$ and the schemes generally operated according to the contract entered into.

The New Zealand Workers' Compensation for Accidents Act 1900, was partially a response to 1896 Brunner Mine disaster, which killed 65 miners (as the population of New Zealand at the time was only about 750,000, the disaster represented one in twelve thousand dying). ${ }^{55}$ Building on the earlier attempts of Richard Seddon's Coal Mines Act 1891, which imposed a levy on mining companies, the Act replaced the requirement to prove fault on the part of the employer with a requirement to show the injury was "suffered in the course of employment". Workers gave up (at least partially) their rights to sue in return for the certainty of administratively determined entitlements. The legislation "established that, regardless of fault, employers had to accept some part of the losses their workers suffered from injuries and accidents in their workplaces. ${ }^{.56}$

By the 1960s there was growing disquiet over the operation of workers' compensation in New Zealand. Concerns had been raised about the costs and operation of the workers' compensation regime. ${ }^{57}$ Payments had fallen to 53 per cent of the average weekly wage

\footnotetext{
${ }^{54}$ The Employer Liability Act 1882 resulted in more employers looking to insure against potential liability for injured workers.

${ }^{55}$ Brian Easton "The Foundations of Social Welfare in New Zealand" (Sept 2017) $<$ https://www.eastonbh.ac.nz/2011/02/the-foundations-of-social-welfare-in-new-zealand/>; See also the discussion in Armstrong, above at n 52, at 9-20.

${ }^{56}$ Melanie Nolan "Inequality of luck: Accident Compensation in New Zealand and Australia" (2013) 104 Labour History 189.

${ }^{57}$ Brian Easton "The Historical Context of the Woodhouse Commission" [2003] 34 VUW Law Rv 293; Murdo MacMillan “Accident Compensation in New Zealand: A Study of Change 1979-1982” (Victoria University Thesis Repository, 1983).
} 
and stopped after six years, despite continuing incapacity. ${ }^{58}$ New Zealand was also a signatory to the ILO Convention 121 Absolute Liability Workers' Compensation, which many considered the country had a duty to implement. ${ }^{59}$ The then Minister for Labour, Tom Shand, said: ${ }^{60}$

I frankly believe that the time has come for the abolition of common law claims for accidents in industry, but before contemplating taking away that right we must make up our minds that the alternative compensation provided in workers' compensation legislation must be more generous, full and fitting than it is today.

\section{The Woodhouse Report and the ACC Scheme}

The ACC scheme arose out of the 1967 Report of the Royal Commission of Inquiry in to Compensation for Personal Injury in New Zealand, chaired by the then Justice Woodhouse. The Royal Commission was set up with the original brief to survey and report on "the law relating to compensation and claims for damages for incapacity or death arising out of accidents (including diseases) suffered by persons in employment..."61 The Royal Commission, however, went much further than its original brief, to improve the workers' compensation system, and proposed a radically different approach. Woodhouse established five guiding principles: ${ }^{62}$

1. Community Responsibility. In the national interest, as a matter of national obligation, the community must protect all citizens (including the self-employed) and the housewives who sustain them, from the burden of sudden individual losses when their ability to contribute to the general welfare by work has been interrupted by physical incapacity.

2. Comprehensive entitlement. All injured persons should receive compensation from any community financed scheme on the same uniform method of assessment, regardless of the causes which gave rise to their injuries.

\footnotetext{
${ }^{58}$ Nadine McDonnell "New Zealand's Workers' Compensation: How will it fare in a changing environment?" paper presented to the 2008 New Zealand Labour, Employment and Work Conference at Victoria University of Wellington.

${ }^{59}$ Ian Campbell Compensation for personal injury in New Zealand: Its rise and fall (Auckland University Press, Auckland, 1996), at 42.

${ }^{60}$ (18 September 1964) 340 NZPD 2292 (Workers' Compensation Amendment Bill- Tom Shand).

${ }^{61}$ At 30 .

${ }^{62}$ Woodhouse Report, at 39.
} 
3. Complete rehabilitation. The scheme must be deliberately organised to urge forward the physical and vocational recovery of these citizens while at the same time providing a real measure of money compensation for their losses.

4. Real compensation. Real compensation demands for the whole period of incapacity, the provision of income-related benefits for lost income and recognition of the fact that any permanent bodily impairment is a loss in itself, regardless of its effect on earning capacity.

5. Administrative efficiency. The achievement of the system will be eroded to the extent that its benefits are delayed, or are inconsistently assessed, or the system itself is administered by methods that are economically wasteful.

The report advocated the expansion of compensation beyond those "harms arising out of, or in the course of, employment" as in the existing Workers' Compensation Act 1956, ${ }^{63}$ and asserted that accidental harms from whatever source were equally deserving of a community level response. ${ }^{64}$ The injury at work was seen as no different to an injury suffered in a vehicle collision, on the rugby field, or tripping over the cat. What made harm compensable in this analysis was not the circumstances of the cause, nor the breach of a legal duty, but rather the harm and resulting incapacity itself. As the report stated, "[i]njury, not cause, is the issue." ${ }^{\prime 65}$ Essentially, the Woodhouse Report advocated a shift to a social insurance model on the basis that the same harms should receive the same treatment.

The Woodhouse Report had grand visions for a scheme of universal coverage for all the "hazards of modern living"66 including all diseases. ${ }^{67}$ However, to ensure the political viability of the proposal at the time, a boundary line for cover was drawn around "accidents," and then further confined by the Gair Committee reviewing the proposal to prevent a split within the National Party over the report. ${ }^{68}$ The wider ambitions of the scheme were left to be enacted later. The Minister in charge of the Bill stated: "[ $t]$ he Accident Compensation Bill was not the end of the road," and emphasised that the Bill was "a step in the right direction," with the new Accident Compensation Commission instructed

\footnotetext{
${ }^{63}$ See discussion in Part Four of the Woodhouse Report.

${ }^{64}$ Above.

${ }^{65}$ At 20.

${ }^{66}$ At 34.

${ }^{67}$ At 144.

${ }^{68}$ See discussion of this in Campbell, above at $\mathrm{n} 59$, and also Palmer, above at $\mathrm{n} 50$.
} 
to investigate the "desirability of extending the scheme." 69 The Labour Party Opposition at the time supported the Bill, but criticised the Government for its hasty approach and unfinished drafting, promising to “...take this emasculated Bill... and rewrite it" and introduce the scheme intended by Woodhouse. ${ }^{70}$

While the Accident Compensation Act 1972 had been confined to "accidents" with cover for diseases generally rejected as "too great a step", there was one category of diseases included. ${ }^{71}$ "Occupational diseases" had previously been covered under the workers' compensation legislation. Although occupational diseases did not fit the new rationale for the scheme, they could not be excluded from it, as to do so would deprive workers of an existing entitlement. The exclusion would have resulted in resistance to the proposal by organised labour, which had fought for the cover of those diseases for many decades. Unions at the time were sceptical about the Woodhouse Report proposals for a number of reasons, including the potential risks to workers' compensation coverage in future. ${ }^{72}$ The recommendations of the New Zealand Federation of Labour in 1967 were for "[a] Workers Compensation Act in line with present day needs and the 1965 ILO Convention."73

The exclusion of occupational disease would have also jeopardised the political alliances needed to progress the Bill through the Gair Committee. ${ }^{74}$ The 1972 Act imported the occupational diseases provisions, as they stood, from the Workers Compensation Act 1956, and described them as an "extension of cover" making their status as an exception to the "accident" focus of the legislation clear. ${ }^{75}$ The occupational disease provisions were intended as an interim measure until the broader vision of the scheme could be realised.

\footnotetext{
${ }^{69}$ (3 October 1972) 381 NZPD 2983 (Accident Compensation Bill- David Thomson).

70 (3 October 1972) 381 NZPD 3023 (Accident Compensation Bill- Arthur Faulkner).

71 (3 October 1972) 381 NZPD 2985 (Accident Compensation Bill- David Thomson).

${ }^{72}$ MacMillan, above at $\mathrm{n} 57$.

${ }^{73}$ New Zealand Federation of Labour $31^{\text {st }}$ Annual Conference Report (Standard Press, Wellington, 1968).

${ }^{74}$ Campbell, above at $\mathrm{n}$ 59, and Palmer, above at n 50.

${ }^{75}$ Accident Compensation Act 1972, ss 65 and 67.
} 


\section{$V$ The Difficult Decades that Followed}

In 1989 an attempt was made to extend ACC cover to all sickness and disease, following an Officials Committee Report ${ }^{76}$ and a Law Commission Report (headed by Sir Owen Woodhouse) ${ }^{77}$ However, the Labour Party lost the election and these proposals were scrapped by the incoming National Government in 1990, which favoured a shift towards a private insurance model. ${ }^{78}$ By 1990, New Zealand was experiencing a sharp ideological shift to the right, and this can be seen in the Accident Compensation Act 1992, which adjusted individual employer levies on the basis of claims costs, prescribed entitlements for claimants, privatised the employers' account and introduced the work capacity test. ${ }^{79}$

The cover of work-related health problems suffered in these reforms, with stricter drafting and new limits introduced. The coverage of "mental injury" was also radically confined. ${ }^{80}$ These reforms were accompanied by the Health and Safety in Employment Act 1992, and the Employment Contracts Act 1991, described at the time as the "completion of "the triad" by employers, ${ }^{81}$ and shifting the regulation of employment relationships towards a more individualistic and contractual model. ${ }^{82}$ Neoliberal ambitions for ACC were advanced

\footnotetext{
${ }^{76}$ New Zealand Officials Committee Review of the Officials Committee of the Accident Compensation Scheme (NZ Government, Wellington, 1986).

${ }^{77}$ Three reports occurred in the period leading up to the Labour Government introduction of proposed reforms. New Zealand Law Commission Accident Compensation Scheme: Interim Report on Aspects of Funding (New Zealand Law Commission, Wellington, 1987), New Zealand Law Commission Personal Injury Prevention and Recovery: Report on the Accident Compensation Scheme (Law Commission, Wellington, 1988) and New Zealand Royal Commission on Social Policy April Report: Report of the Royal Commission on Social Policy (Government Printer, Wellington, 1988).

${ }^{78}$ Birch, above at $\mathrm{n} 47$.

${ }^{79}$ See discussion of these reforms Armstrong, above at $\mathrm{n} 52$, at 36.

${ }^{80}$ For discussion of the history of "mental injury" under ACC see Fiona Thwaites "Mental injury claims under the Accident Compensation Act 2001" 18 Canterbury Law Rev 244. Prior to the 1992 Act compensation for mental injury had followed the prior common law approach.

${ }^{81}$ See discussion in New Zealand Council of Trade Unions (NZCTU) The Dupes of Hazard: A Critical Review of the Health and Safety Act 1992 in Practice (NZCTU, Wellington,1994), at iii.

${ }^{82}$ See Gordon Anderson Reconstructing New Zealand's labour law, consensus or divergence? (VUP, Wellington, 2011).
} 
further in a 1998 report prepared for the New Zealand Business Roundtable, ${ }^{83}$ with ACC then privatised for a brief period between July 1999 and June 2000.

The Labour-led Coalition Government (1999-2008) enacted the Injury Prevention Rehabilitation and Compensation Act 2001, which reversed some of the changes made by the previous regime, but abandoned its prior ambition to enact the full social insurance scheme proposed in the Woodhouse Report. There have been many small amendments made in the 18 years since, adding or trimming the cover available to workers, but doing little to address the fundamental problems or update the scheme. This has left the ACC scheme in urgent need of reform, as highlighted by a number of recent reports. ${ }^{84}$ The current Minister for ACC, Iain Lees-Galloway, has indicated his intention to introduce new ACC legislation in late 2019. There are also renewed calls to enact the full Woodhouse Report proposals, reigniting the political, ideological and philosophical debates at the heart of the scheme. ${ }^{85}$

\section{Workers' Compensation or Social Insurance}

The Woodhouse Report advocated a radical shift to a social insurance model, based on a belief in community responsibility and a claim that we should "all share in sustaining those who become the random but statistically necessary victims" of "community activities." 86 As Sir Geoffrey Palmer points out: ${ }^{87}$

The ultimate issues in the New Zealand accident compensation reforms were not about the law. They were about values. They concerned social priorities. The choices were political. The debate was about which matters should be handled as a matter of collective community decision and which matters are best left to the market to be dealt with on a commercial basis.

\footnotetext{
${ }^{83}$ Cushla Thomson, Susan Begg and Bryce Wilkinson Accident Compensation: Options for Reform (Credit Suisse First Boston and New Zealand Business Roundtable, Wellington, 1998).

${ }^{84}$ See Acclaim Otago (Inc), Miriam Dean and Warren Forster, Tom Barraclough and Tiho Maijatov, above at $\mathrm{n} 9$.

${ }^{85}$ See Geoffrey Palmer, above at n 13; and OECD, above at n 10.

${ }^{86}$ Woodhouse Report, at 39.

${ }^{87}$ Geoffrey Palmer “The Future of Community Responsibility” (2004) 35 VUWLR 905, at 906.
} 
The difference between the schemes was more than just scope of coverage. Workers' compensation schemes and social insurance schemes have very different underlying assumptions, objectives and understandings of the cause and nature of the harm being compensated, and as a result, who ought to be made responsible for it. This thesis asserts that these differences in assumptions are at the root of the problems in the current drafting and why the political compromise made to limit the scope of the scheme to "accidents" created such a difficult legacy.

The calls to enact a comprehensive social insurance scheme arose from a different context and rest on a different set of principles to the prior workers' compensation scheme. As will be discussed further in Chapter Three, rather than emerging from an industrial relations context, concerned with the conditions of work, the social insurance model traces its intellectual origins to the early public health and social welfare reformers. ${ }^{88}$ Social insurance seeks not only to cover those health conditions directly connected to the performance of work, but also the wider category of "workers' diseases." The term workers' diseases, originally coined in the $1880 \mathrm{~s}$, reflects a different basis for the claim, and refers to the "maladies which occurred more frequently in one class or stratum of society, irrespective of specific categorisation or cause." 89 Workers' diseases were linked with the so-called "social question." 90

This social question... can be regarded as the costs of capitalist industrial development, and includes... poverty, pauperisation, particularly in the cities, the question of lodgings for the workers, and the lack of social security for the old and infirm.... problems like cholera, public health and infant mortality.

\footnotetext{
${ }^{88}$ For a discussion of the historical development of New Zealand's social welfare system see Andrew Sharp The welfare tradition: Social welfare, New Zealand since 1891 (Heinemann Educational, Auckland, 1975) and Myra Kunowski The first hundred years: Social welfare in New Zealand from 1891 (Heinemann Educational, Auckland, 1988).

${ }^{89}$ Muir Popper Lehrbuch der Arbeiterkrankheitan und Gewerbehygiene (Stuttgart, 1882) in Dietrich Milles "From Workers' Diseases to Occupational Diseases: The Impact of Experts' Concepts on Workers Attitudes" in Paul Weindling (ed) The Social History of Occupational Health (Croom Helm, Kent, 1985) at 61.

${ }^{90}$ Dietrich Milles “From Workers' Diseases to Occupational Diseases: The Impact of Experts' Concepts on Workers Attitudes" in Paul Weindling, above, at 58.
} 
The social insurance model seeks to spread the costs of the negative health effects of capitalist modes of production amongst society as a whole, rather than making those controlling and profiting from work directly responsible to those affected, through interventions in their contractual relationships. Social insurance was argued to form part of a "social contract" between citizen and state, and sat alongside calls for the provision of pensions, unemployment benefits and a national health service. ${ }^{91}$

The earliest calls for a social insurance approach in New Zealand date from the 1930s, with an unsuccessful Bill being put to Parliament in 1937 to cover motor vehicle accidents. ${ }^{92}$ The notion of no fault compensation "continued to simmer in legal circles" until the 1960s. ${ }^{93}$ In 1962 Parliament established the Committee on Absolute Liability to "report on the desirability of the introduction of some form of absolute liability for deaths, and for bodily injuries, arising out of the use of motor vehicles." 94 The committee concluded "no present change in the law could be recommended," but found that: ${ }^{95}$

There is a case for an accident insurance scheme which would cover all persons who are injured in any way without negligence on their part, provided the community can afford to bear the cost on an equitable basis.

By the time of the 1967 Royal Commission, conditions in New Zealand were ripe for advocating a social insurance approach. The growing post-war trend toward welfare and state provision (e.g. health care, education and social housing) ${ }^{96}$ coincided with a peak in the rates of industrial and road accidents, ${ }^{97}$ increasing critiques of the compensation available at common law, ${ }^{98}$ and a number of major studies and reports, including the

\footnotetext{
${ }^{91}$ See Sharp and Kunowski above at $\mathrm{n} 88$.

92 Westlaw Online Looseleaf (editor unknown) Personal Injury in New Zealand, at HA4.

93 Above.

${ }^{94}$ Committee on Absolute Liability Report of the Committee on Absolute Liability for Motor Vehicle Accidents (Government Printer, Wellington, 1963).

95 Report of the Committee on Absolute Liability for Motor Vehicle Accidents, at para 40.

${ }^{96}$ Nolan, above n 56 at 109, and Purse and Guthrie, above at n 52.

97 Nolan, at 109.

${ }^{98}$ Lord Parker of Waddington "Compensation for Accidents on the Road: An Address" in Current Legal Problems 18 (1965); Terence Ison The Forensic Lottery: A Critique on Tort Liability as a System of Personal Injury Compensation (Staples Press, London, 1967).
} 
Meredith Report in Canada and the Beveridge Report in the UK. ${ }^{99}$ The idea was also put forward in Australia. ${ }^{100}$ In 1973 the Whitlam Government appointed a Committee of Inquiry into Compensation and Rehabilitation in Australia which was also chaired by Woodhouse. The Australian National Compensation Bill (Cth), which would have seen an Australian-wide ACC equivalent became a casualty of the fall of the Whitlam government in 1975. ${ }^{101}$ The Australians did not adopt the model advocated in their version of the Woodhouse Report. In Australia, there are eleven workers' compensation schemes currently operating. ${ }^{102}$ Each state and territory have a scheme, and there are also three commonwealth schemes, each with slightly different drafting, and varying access to the common law actions. ${ }^{103}$ The Australian workers' compensation regimes provide a useful set of comparators for this thesis.

\footnotetext{
${ }^{99}$ William Meredith Final Report on the Liability of Employers to make Compensation to their Employees for Injuries Received in the Course of their Employment which are in Force in other Countries, and as to How Far Such Laws are found to Work Satisfactorily (Government Printer, Toronto, 1913) "The Meredith Report". William Beveridge Social Insurance and Allied Services Report by Sir William Beveridge (MNSO, London, 1942)

${ }^{100}$ The Whitlam Government appointed a Committee of Inquiry into Compensation and Rehabilitation in Australia chaired by Justice Owen Woodhouse; National Rehabilitation and Compensation Scheme Committee of Inquiry Report of the Committee of Inquiry into Compensation and Rehabilitation in Australia (Government Printer, Canberra, 1976). The National Compensation Bill, which would have seen an Australian-wide ACC equivalent became a casualty of the fall of the Whitlam government in 1975. See also discussion by Nolan, above $n 56$.

${ }^{101}$ See National Rehabilitation and Compensation Scheme Committee of Inquiry, above and Nolan, above. See also Mark Robinson Accident Compensation in Australia: No Fault Schemes (Legal Books, Sydney, 1987).

102 See SafeWork Australia Comparison of Workers' Compensation Arrangements in Australia and New Zealand (SafeWork Australia, Canberra, 2011); and Alex Collie "Australian Workers' Compensation Schemes" in Eileen Willis, Louise Reynolds and Helen Keleher (eds) Understanding the Australian Healthcare System ( $3^{\text {rd }}$ ed, Elsevier, Chatswood, 2016).

${ }^{103}$ Above. See also Michael Quinlan "Workers' compensation and the challenges posed by changing patterns of work: Evidence from Australia” (2004) 2(1) Policy and Practice in Health and Safety 25.
} 


\section{A Political Compromise: An Accident Compensation Scheme}

The ACC scheme was a political compromise, described by politicians at the time, as "half a loaf of bread" thought "better than no bread" at all. ${ }^{104}$ While this compromise ensured the success of the proposal and a considerable expansion in cover, drawing the boundary lines around the concept of "accident" left the scheme with an inherent tension. Social insurance schemes can be thought of as an "all or nothing" deal. The underlying rationale of a social insurance scheme is that all people suffering from harm deserve to be cared for equally. This type of reasoning does not easily lend itself to drawing lines between different claims. A scheme with coverage only for accidents leads to an inevitable question of definition. An accident, in plain meaning, is "an unexpected event with negative consequences"105 or something "happening by chance or accident; not planned [or] unexpected." 106 If the scheme cannot (or there is no political will to) compensate all such consequences, then a question as to which accidents should be compensated naturally arises.

This can be explained further in comparison to the operation of workers' compensation schemes. Workers' compensation schemes, such as those operating in Australia, seek to compensate workers for the negative health consequences of work, whether accidental physical injury or work-related disease. The schemes are designed for "workers," as defined, and for those conditions that have a sufficient causal connection to work. "Work" becomes the central hinge for determining cover in the scheme. To ration cover, a line can be drawn between work-related harms and those unrelated to work, and the extent of the required causal relationship between work and harm can be adjusted back and forward along the spectrum of causal connection to meet budgetary constraints. The underlying rationale of workers' compensation, "to compensate workers harmed at work," can remain,

\footnotetext{
104 (3 October 1972) 381 NZPD 2985 (Accident Compensation Bill- Dr Finlay).

105 “Accident” Merriam Webster Dictionary Online (Feb 2017) < https://www.merriamwebster.com/dictionary/accident>

106 “Accident” Dictionary.com (Feb 2017) < https://www.dictionary.com/browse/accident> 
but the causal tests, the margins of cover, and the interaction of the provisions with the rest of the legal system can shift with the ideological tides.

In an "accident" compensation scheme there is no basis in principle for what should be included or excluded from its scope. Accident, as a concept, is unhelpful in drawing boundary lines for cover. There is nothing particularly distinct or morally deserving about the health conditions presently grouped in that category for the purposes of the ACC legislation. As Sir Geoffrey Palmer identified in 1977 the ACC scheme has developed a "cut and fill approach," of small-scale ad hoc amendment, with policy analysts often failing "to see the forest for the trees." 107 This thesis asserts that this pattern is the logical consequence of the centrality of "accident" to the scheme. If the starting assumption is, as in the Woodhouse Report, that all incapacities are equally deserving, regardless of cause, and notions of fault are inappropriate, to ration cover the legislation must draw lines between medical conditions. The entitlement question begins to focus on exactly where and how in the body harm comes to be, resulting in an excessively body-focussed drafting and the codification of diagnostic criteria. As discussed further in Chapter Four, a scheme with no principled basis for drawing its boundary lines, and with drafting that encourages ad hoc, reactive and diagnosis specific amendments, very soon runs in to problems in adapting to changing working patterns and medical thinking.

\section{Conclusion}

Despite the wider ambitions of Woodhouse and fellow reformers the ACC scheme proposed in 1967 was limited to "accidents." Drawing the boundaries of cover around the concept of "accident" occurred not because accidents represent some particularly identifiable or deserving category, but for political reasons, intended to ensure a more manageable start to the comprehensive social insurance project. The decision to confine the original scheme to "accidents," however, created a significant theoretical tension that

${ }^{107}$ Geoffrey Palmer "Accident Compensation in New Zealand: The First Two Years” (1977) 25 Am J Comp L 1, at 8. 
this thesis asserts sits at the root of the current coverage problems. The scheme is neither a comprehensive social insurance scheme, nor is it a workers' compensation scheme, but a partial and compromised hybrid of both. Despite the attempted privatisation in the 1990s, the scheme is not operating as a state-owned insurance scheme either. The current scheme has, however, borrowed heavily from the assumptions and operational practices of private insurance, which further exacerbates its comprised functions and undermines its restored statement of purpose "to enhance the public good and reinforce the social contract". ${ }^{108}$ The unique history of the ACC scheme poses two fundamental questions for any project of reform: first, a principled question of the basis on which workers harmed at work should be compensated; second, the practical question of how workers harmed at work should be compensated. These questions are discussed further in the following chapter.

${ }^{108}$ ACA, s3. 


\title{
CHAPTER THREE: AIMS, SCOPE AND METHOD
}

\author{
ACC Reform as a Project within Labour Law
}

\section{Introduction}

The aim of this thesis is to examine the compensation of work-related health problems in New Zealand and propose a set of legislative reforms to the ACC scheme which provide for fairer coverage and contribute to improved work health and safety. This aim informs the choice of theoretical approach, method and scope. As set out in the previous chapter, there are three key theoretical approaches to the compensation of workers harmed through work, and a project of ACC reform could have alternatively been framed as a project within social welfare law, seeking to enact the ambition of the original Woodhouse Report, or a combination of tort and insurance law. This project of ACC reform is approached as one within labour law, adopting a purposive labour law method as advocated by Guy Davidov in his 2016 book, A Purposive Approach to Labour Law. ${ }^{109}$ This chapter introduces the purposive labour law approach, explains why it has been selected and how it informs the aim, scope and methods used.

\footnotetext{
${ }^{109}$ Guy Davidov A Purposive Approach to Labour Law, above at n 39.
} 


\section{An Introduction to Labour Law}

Labour law is often defined as "the combination of subject matter and purpose" 110 or "an area of law on a mission." "111 Labour law, as a theoretical approach, is distinct from employment law as an area of legal rules. Employment law is a descriptive term for those laws that relate to the relationship of employment. Labour law adopts a unique approach, resting on a set of normative frameworks and directed towards achieving explicit ends. Kahn-Freund articulates the ends of labour law as follows: ${ }^{112}$

The main object of labour law has always been, and we venture to say always will be, to be a countervailing force to counteract the inequality of bargaining power which is inherent and must be inherent in the employment relationship.

The labour law literature, beginning with Hugo Sinzheimer and Otto Kahn-Freund, tends to involve an explicit appeal to a set of normative frameworks and specific goals, most often articulated as "addressing the inherent inequalities of bargaining power" between workers and capital. Kahn-Freund describes the relationship as: ${ }^{113}$

.... relation between a bearer of power and one who is not a bearer of power. In its inception it is an act of submission, in its operation it is a condition of subordination, however much that the submission and subordination may be concealed by that indispensable fiction of the legal mind known as the "contract" of employment.

Labour law scholarship generally rests on a set of assumptions about the relationship between workers and those engaging them to perform work, and the importance of this relationship in the social, economic and political system. As Anderson sets out "[e]conomically the imperative in all employment relationships is to ensure the performance of work." 114 Labour law seeks to ensure the protection of those performing work and "displays a justified bias in favour of the employee." 115

\footnotetext{
${ }^{110}$ John Howe, above at n 37, at 295.

${ }^{111}$ Martin Vranken Death of Labour Law? Comparative Perspectives (Melbourne University Press, Melbourne, 2009), at 32.

${ }^{112}$ Otto Kahn-Freund Labour and the Law (2 $2^{\text {nd }}$ ed, Stevens, London, 1977) at 6.

${ }^{113}$ Kahn-Freund, above, at 8.

${ }^{114}$ Gordon Anderson, above at $\mathrm{n}$ 82, at 13.

${ }^{115}$ Vranken, above at $\mathrm{n} 111$, at 15.
} 
From a labour law perspective, the employment relationship is not just a contract like any other and the employer and employee are not equal parties with an alignment of interests. ${ }^{116}$ Labour law scholarship assumes an inherent conflict between the interests of those that own the business in the generation of the maximum possible profits and the terms and conditions of work. Inequality in bargaining power results in wages and conditions being set at the lowest levels possible as workers compete for scarce jobs. The role of labour law is to intervene in this bargain for the benefit of workers. The origins of labour law are either attributed to the industrial revolution or the recession of the $1880 \mathrm{~s}$ and $1890 \mathrm{~s} .{ }^{117}$ As explained by Weiss: ${ }^{118}$

In the $19^{\text {th }}$ century it became evident that the competition between individual employees at the labour market was a race to the bottom and that only collectivisation of employees combined with protective legislation could prevent this destiny... The main goal always has been to compensate the inequality of bargaining power.

The labour law scholarship typically views the relationship of employment as distinct from other legal relationships and requiring of special attention. While, of course in practice, no area of law can exist in total isolation and "fortress labour law" is generally rejected, the autonomy of labour law is a key component of the approach. Wedderburn, in his wellknown article, set out that: ${ }^{119}$

\begin{abstract}
Labour law must break free from the assumptions of underlying institutions of the civil law, the property rights of the employer, through which he controls work and the enterprise, the prerogative of the proprietor to organise and distribute work, and the status of subordination attached to the worker. The contract of employment could be retained as representing a free choice to enter an employment relationship; but it must be modified, on the base rather of agreement... than of hierarchic subordination. Above all labour law was distinguished from civil law by its collective character, its umbilical cord to the social facts...
\end{abstract}

In the book, The Autonomy of Labour Law, the claim of autonomy is investigated further, at three levels. First, at a meta-level, the idea that labour law embodies a distinctive set of normative precepts or ideals is examined. Second, the claim of autonomy is analysed at the

\footnotetext{
${ }^{116}$ See Gordon Anderson, Douglas Brodie and Joellen Riley The common law employment relationship: $A$ comparative study (Edward Elgar, Cheltenham, 2017).

${ }^{117}$ Vranken, above, at n 111, at 15.

${ }^{118}$ Manfred Weiss "Re-Inventing Labour Law?" in Davidov and Langille, above at $\mathrm{n}$ 37, at 44.

${ }^{119}$ Lord Wedderburn "Labour Law: From Here to Autonomy?" (1987) 16 Indus L J 1.
} 
mid-level, primarily looking at the work of Kahn-Freund and the autonomy of actors. Thirdly, autonomy is examined at the substantive level, concerned with a distinctive set of legal rules and principles. ${ }^{120}$ For the purpose of this thesis, the claim of autonomy is drawn on to inform and justify decisions of project scope and approach, particularly the choice to frame the project as one within labour law and one focussed on advancing the interests of workers. The unique nature of labour law and the need to recognise its autonomy also informs the structure and position of the workers' compensation provisions in the proposed legislation advanced in Chapters Seven and Eight.

The labour law scholarship of recent decades has focused its attention on how best to respond to a changing economic and political context. Traditional assumptions about how to regulate work are challenged by globalisation and the move from production to financial capitalism, the disruption resulting from the shift from ownership-based production systems to contractual supply-chains, the rise in "non-standard" employment relationships, increasing organisational flexibility and resulting precarity, and the rise of artificial intelligence, platform and gig-work. ${ }^{121}$ These changes have prompted some to declare a "crisis of labour law" or even the "death of labour law." ${ }^{122}$ Langille outlines the three dimensions of the asserted "crisis" in labour law as being: ${ }^{123}$

(1) empirical (has the real world changed so much as to leave traditional labour law beside the point, inoperable, fading from view?); (2) conceptual (are our basic concepts of 'employee', 'employer', employment contracts, and so on, still viable and capable of organizing our thinking in a useful way?); and (3) normative (are the moral ideas which motivate our enterprise still salient, robust, and capable of rallying us to the continued defence of our subject?).

The literature on the factors contributing to labour law's "crisis" is drawn on in Chapter Five when examining the relationships between the organisation and control of work and resulting worker ill-health. While claims of crisis, and even death have been made, the field

\footnotetext{
${ }^{120}$ Alan Bogg, Cathryn Costello, ACL Davis and Jeremais Prassl (eds) The Autonomy of Labour Law (Hart Publishing, Oxford, 2015).

${ }^{121}$ See Judy Fudge "Regulating for decent work in a global economy" (2018) 43(2) NZJER 10.

${ }^{122}$ See Keith Ewing "The Death of Labour Law" (1988) 8 Oxford Journal of Legal Studies 293; Cynthia

Estlund "The Death of Labour Law" (2006) 2 Annual Review of Law and Social Sciences 105; and

Cynthia Estlund "The Ossification of American Labour Law" (2007) 102 Columbia Law Rev 1527.

${ }^{123}$ Brian Langille "Labour Law's Theory of Justice", in Davidov and Langille, above at n 37, at 101.
} 
is perhaps better described as going through some re-examination of its principles and disciplinary boundaries in light of changes to the nature of work. ${ }^{124}$

\section{Davidov's Purposive Approach to Labour Law}

Davidov's book, A Purposive Approach to Labour Law, was written in response to the assertions of crisis within the field, which he describes as a "cliché."125

It seems that labour law is always in crisis. Perhaps this is not surprising; labour laws have clear and direct distributional effects, and as such they invite resistance and evasion, which lead to on-going problems of enforcement, calls for deregulation, and a perpetual need to re-assert the justification of regulations in this field. Moreover, labour markets are dynamic, so the laws regulating them require continuous adaptations; but given the background of resistance and evasion, such adaptations are often not politically feasible. Therefore the ingredients of a crisis are arguably an inherent part of labour law.

Davidov argues that the goals of labour law remain as valid as ever, and the real problem, as he sees it, is in the mismatch between the goals of labour law and its means: ${ }^{126}$

...many regulations have lost their harmonization with the goals they are supposed to advance. This mismatch leads to a problem of coverage (workers who need the protection of labour law are not covered by it), as well as a problem of obsoleteness (laws have not been sufficiently updated in light of changes in the labour market). The book seeks to address this crisis by using a purposive approach.

Davidov's characterisation of the problems facing labour law, looks very similar to the problems facing the ACC scheme. Essentially, the goals of workers' compensation, including improved health and safety, cannot be achieved with "the means" of the current ACA, being a politically compromised hybrid of workers' compensation, social welfare

\footnotetext{
$\overline{{ }^{124} \text { See Guy Davidov and Brian Langille "Understanding Labour Law: A Timeless Idea, A Timed-out Idea, }}$ or an Idea whose Time has Now Come?" and Manfred Weiss "Re-Inventing Labour Law?" in Davidov and Langille, above at n 37. See also Ruth Dukes The Labour Constitution: The Enduring Idea of Labour Law (Oxford University Press, Oxford, 2014); and Christopher Arup, Peter Gehan, John Howe, Richard Johnstone, Richard Mitchell and Anthony O'Donnell (eds) Labour Law and Labour Market Regulation (Federation Press, Sydney, 2006).

${ }^{125}$ Davidov, above at $\mathrm{n} 39$, at 7.

${ }^{126}$ Above at $\mathrm{n} 39$, at 1 .
} 
and private insurance. As discussed further in Chapter Four, confining the scheme to accidents, and drafting the workers' compensation provisions as "exceptions" created a difficult legacy for subsequent drafters and had an undermining effect on work health and safety in the decades that followed.

ACC also suffers from the problems of "obsoleteness" identified by Davidov. The scheme is now 50 years old and in need of reform to be able to respond to changing patterns of work, and the rapidly changing medical thinking on the causal relationships in work-related health problems. As discussed in Chapter Five, work has changed a great deal from the 1960s, when Woodhouse was writing, with the rise of stressful work resulting in a very different set of work-related health conditions in need of a legal response.

Davidov's suggested solution to these problems is "to restore the connection between labour laws and the goals behind them." 127 This is done by first clearly understanding the principles and goals of labour law, and then articulating them explicitly for the project of reform. Davidov explains that his approach: ${ }^{128}$

\footnotetext{
...starts from a very simple premise: labour laws (like all other laws) are means to an end; we need them, and use them, to advance societal goals. Given the mismatch just described, we have to restore the connection between labour laws and the goals behind them. To do so, we first have to understand, and articulate, the goals - to explain to ourselves (and to legislatures, courts, employees, and employers) the purpose of labour laws at the deepest possible level. The next step is then to reconsider our means - to ask what we need to change or improve in the laws themselves in order to better advance the goals.
}

This can be summarised into four steps: (1) an examination of the goals of labour law at a principled level; (2) an articulation of particular goals for the law to be reformed; (3) an analysis of the "means" being used and whether such means can achieve the goals set; and (4) an identification of what is needed to ensure the means can achieve the ends sought.

\footnotetext{
127 At 3 .
}

${ }^{128}$ At 4. 
There have been some criticisms of Davidov's purposive approach, ${ }^{129}$ and it undoubtedly has its limitations as a means for addressing the wider forces of market capitalism. ${ }^{130}$ That said, it provides a thorough analysis of the goals of labour law and a framework for labour law reform projects. It is particularly useful for this project as a means for restoring a principled basis to workers' compensation in New Zealand and addressing historical compromises. There is a real and obvious mismatch between the goals (fair and equitable compensation and the prevention of work-related injury and illness) and the "means" of the current drafting in the ACA.

\section{A Translating Davidov's approach in to a specific method}

Davidov's purposive labour law approach can be translated in to a specific three step method for this thesis as follows:

Step One: Literature review and analysis of the principles and goals of labour law and an articulation of specific 'labour law' goals for the project.

This step builds on the theoretical and political context provided in the previous chapter, with a review of the literature and a discussion of the way labour law goals can be articulated as a broad principled approach to health and safety and workers' compensation laws. As to be discussed, health and safety and workers' compensation subjects have typically received less philosophical and theoretical attention than other areas of labour law, either because of the apparent obviousness of the goals (killing and incapacitating fewer workers) or because of its asserted "unsexy" and "intellectually unworthy" subject

\footnotetext{
${ }^{129}$ Harry Arthurs "Can Davidov's slingshot slay the Goliath of political economy? On Guy Davidov's purposive approach to labour law" (2017) 6(1) Jerusalem Review of Legal Studies 1; Einat Albin "The missing context: Comments on a purposive approach to labour law" (2017) 16(1) Jerusalem Review of Legal Studies 15; Simon Deakin "Labour law: The pragmatists guide - Comments on Guy Davidov's A purposive Approach to Labour Law" (2017) 16(1) Jerusalem Review of Legal Studies 28.

${ }^{130}$ Arthurs, above, at n 129.
} 
matter. ${ }^{131}$ This step involves a theoretical examination and then formulating a set of labour law goals for the project, allowing for the articulation of "why" as well as just "what" is sought. This is an important point, as on its face, all three theoretical approaches discussed in the previous chapter seek to compensate workers and reduce work-related injury and illness. It will be argued that understanding the reason that a reduction of injuries and illnesses is sought (e.g. the inherent dignity of workers as compared to the more efficient allocation of losses) is essential when designing a legislative response. A key component of Davidov's approach is the need to start with a better understanding of the "ends" sought before an analysis of the means.

Step Two: An analysis of the current "means" and why these are not achieving the goals identified in step one.

Chapters Four and Five of this thesis provide an analysis of the work-related cover provisions in the current ACA. Chapter Four provides a detailed examination of the problems in the current drafting of the ACA, highlighting the unfair, unequal and unjustifiable exclusions of many work-related health conditions from cover and the consequences for workers. It also explains how the current ACA results in negative consequences for work health and safety. Chapter Five examines the changing patterns of work and work-related ill-health that need to be understood for the ACC scheme to be able to achieve its goals in the future. This step employs a combination of traditional legal analysis (analysing relevant legislation and case law), a functional comparative labour law analysis (discussed further below) and wider socio-legal methods, exploring the literature on changing patterns of working hazards and health conditions.

Step Three: Identify the means needed to be able to achieve the goals sought.

This is contained in Chapters Six, Seven and Eight. Chapter Six provides the theoretical basis for a new approach to causation, arguing that when developing a new causal test, the

${ }^{131}$ Harry Arthurs "Charting the boundaries of labour law: Innes Christie and the search for an integrated law of labour market regulation" (2011) 34(1) Dalhousie Law Journal 1, at 6. 
drafter should be conscious of the resulting causal narratives of work-related injury and illness created, and the impact of these narratives on actors. Chapter Seven then translates this approach in to a new Act, restoring the focus of the legislation to work and its hazards, allowing it to better respond to a future of increasing factual and evidential complexity and also shifting the language and behaviour of actors towards health and safety. This new approach is argued to realign both sides of the legal response (health and safety and workers' compensation) towards the ends of preventing injury and illness as a means to achieve the goals set. The drafting is then provided in Chapter Seven. This step involves legislative analysis and purposive drafting, as well as an examination of the theoretical literature on causation to understand the way in which the framing of causation in the drafting impacts on the language and behaviour of actors interacting with it.

\section{B A note on comparing labour laws across jurisdictions}

Throughout the three steps, the thesis employs a functional comparative analysis of the laws in other countries as a means to better understand the unique problems in New Zealand's ACC scheme. Kahn-Freund, Blanpain and others emphasise the importance of understanding the local political and economic context when undertaking reform projects. ${ }^{132}$ Blanpain argues that: ${ }^{133}$

[t] he main purpose of comparative law is a better understanding of one's own labour law system. As a source of experience made elsewhere, comparative labour law may serve as an important tool in legal reform.

The value of drawing on overseas experience is to better highlight the structural or systemic problems within the coverage provisions of the ACC scheme. The injuries and illnesses caused by work are not unique to New Zealand, even though the ACC scheme is. As in many other areas of New Zealand law, Australia is the logical comparator. Australia is particularly useful here given the shared health and safety regulation, as the HSWA was drafted to match the Australian Model Work Health and Safety Law. While this thesis

\footnotetext{
${ }^{132} \mathrm{R}$ Blanpain "Comparitivism in Labour Law and Industrial Relations" in Comparative Labour Law and Industrial Relations in Industrialised Market Economies (Kluwer, The Netherlands, 2010), at 4; Otto KahnFreund "On Uses and Misuses of Comparative Law" (1974) 37(1) MLR 1.

${ }^{133}$ Blanpain, above, at 4.
} 
examines the way in which workers are compensated in other jurisdictions, the aim is not to transplant an Australian or overseas approach in to New Zealand law. As set out by Blanpain: ${ }^{134}$

[c]omparative labour law is only useful if certain prerequisites are fulfilled. Functions and not institutions are to be compared... of utmost importance is an interdisciplinary approach, allowing for the integration of extra-legal factors.

The ACC scheme is unique to New Zealand, and operates in a unique context. While recognising this, the need for laws to ensure workers are fairly compensated, and protected from harm at work is not, nor are the economic forces impacting on the performance of work in New Zealand. Drawing on the overseas literature and experience provides an opportunity to understand the limitations and potential of our particular regime.

\section{Should Reform of the ACC Scheme be thought of as part of Labour Law?}

The boundaries of labour law are undergoing a period of robust scholarly re-examination, with some academics likely to argue that ACC should fall outside the scope of labour law and be better approached as a topic within social welfare law. ${ }^{135}$ This is rejected, as framing workers' compensation functions as part of welfare provision would not achieve the goals sought and would potentially undermine them. Further, it will be argued that health and safety and workers' compensation should be viewed as two inseparable parts of the same legal response, and as part of labour law, and that this view is most consistent with achieving the goals of labour law as articulated in the literature.

When labour law emerged as a distinct field of study in the early part of the $20^{\text {th }}$ century, it was thought properly confined to matters of collective bargaining and the promotion of organised labour. Mitchell argues that the field began in:136

\footnotetext{
134 Above, at 3.

135 Davidov and Langille, and Dukes, above at n 124.

${ }^{136}$ Richard Mitchell "Where are we going in labour law? Some thoughts on a field of scholarship and policy in process of change" (2011) 24 AJLL 45.
} 
...the study of the existing employment relationship - legally embodied in the employment contract - then worked its way out to a treatment of the legal and institutional features of 'the system': an analysis of the laws which are put in place to relieve that imbalance of power. This included the establishment and maintenance of collective rights, collective bargaining, other dispute-resolving mechanisms, the rights of trade unions, rights to industrial action and so on.

The boundaries of labour law have expanded over the decades to include minimum legislated standards, international labour standards and dismissal rights, with subjects like health and safety and anti-discrimination law added during the 1970s and 1980s, ${ }^{137}$ and later business restructuring, ${ }^{138}$ then more recently human rights. ${ }^{139}$ Scholars have also proposed the recasting of labour law as labour market regulation in an attempt to progress boundary issues and incorporate a wider range of regulatory issues affecting the organisation of labour supply and demand. ${ }^{140}$ Some labour law scholars argue the boundaries ought to expand even further, drawing on the literature relating to workplace democracy, universal basic income and models of collective ownership to reinvent itself. ${ }^{141}$

Although Davidov has written on where and how he considers the boundary lines of labour law scholarship to be drawn, he does not examine health and safety or workers' compensation subjects specifically. ${ }^{142}$ In a Purposive Approach to Labour Law, he expressly excludes unpaid work, tenancy laws and social security provision from his characterisation of the field in the book, but concludes: ${ }^{143}$

If we are defining the field of research and study, labour law would surely benefit from a closer inspection of other fields of law that indirectly affect workers, or affect workers outside of an employment relationship. Yet it is highly doubtful if a field of study and research has to be 'defined'

${ }^{137}$ H Collins, 'The Productive Disintegration of Labour Law' (1997) 26 Industrial Law Journal 295.

${ }^{138}$ See Hugh Collins, K D Ewing and Aileen McColgan Labour Law (Hart Publishing, Oxford, 2005).

139 Judy Fudge "Labour rights and human rights: Turning slogans in to legal claims" (2014) 37(2)

Dalhousie L J 601; See also Virginia Mantouvalou “Labour Law and Human Rights" (2016) 41(2) NZJER

3 and Hugh Collins and Virginia Mantouvalou "Human Rights and the Contract of Employment" in Mark

Freedland (ed) The Contract of Employment (Oxford University Press, Oxford, 2016).

${ }^{140}$ See Arup, Gahan, Howe, Johnstone, Mitchell and O’Donnell (eds), above at n .124

${ }^{141}$ See Troy Sarina and Joellen Riley "Re-crafting the enterprise for the gig economy" (2018) 43(2) NZJER 27.

142 Guy Davidov “Settling labour law's coverage: Between universality and selectivity” (2014) 34(3) Oxf J L S 543.

143 At 7. 
at all. Scholars generally enjoy the academic freedom to structure their courses and choose their research topics. To the extent that the call to expand labour law is meant as a call for labour law scholars to engage more closely with related fields in their research and teaching, this is an important and useful point; however, it is not related to the boundaries of labour law in the sense relevant to this book.

Davidov suggests that determining the boundaries of the field be informed by its goals. $\mathrm{He}$ states that the "question is whether there is sufficient commonality to make such grouping useful." ${ }^{144}$ This thesis argues that health and safety and workers' compensation, being viewed as two interrelated parts of the same legal response, are, and ought to be considered, part of labour law. As discussed further in the next section, the ends of labour law, are also the ends of health and safety and workers' compensation laws, and achieving these ends require well designed health and safety and workers' compensation laws that are embedded in the wider regulation of working relationships. Health and safety and workers' compensation laws also offer an important vehicle for challenging complex patterns of work like precarity, intensification and unhealthy remuneration and human resource management practices in a way that collective bargaining or traditional standard setting cannot.

Looking beyond Davidov, to the wider academic discussion of the boundaries of labour law, workers' compensation has been both included and excluded from scholarly treatments. ${ }^{145}$ There has not, however, been any dedicated examination of whether it ought to be considered within the discipline proper, and conclusions seem likely to depend on how the workers' compensation schemes are set up in the various jurisdictions. Health and safety law has typically been included within labour law treatments, although there is often

\footnotetext{
144 At 7.

${ }^{145}$ For the development of the debate on the boundaries of labour law see A Supiot Beyond employment: Changes in work and the future of labour law in Europe (Oxford University Press, Oxford, 2001); J Conaghan, M Fischl and K Klare Labour law in an era of globalization: Transformative practices and possibilities (Oxford University Press, Oxford, 2002); Judy Fudge, Eric Tucker and Leah Vosko "Changing boundaries in employment: Developing a new platform for labour law" (2003) 10 CLELJ 329; Katherine Stone From widgets to digits: Employment regulation for a changing workplace (Cambridge University Press, Cambridge, 2004); Guy Davidov and Brian Langille Boundaries and frontiers of labour law: Goals and means of work regulation (Hart, Oxford and Portland, 2006); Judy Fudge "Feminist reflections on the scope of labour law: Domestic work, social reproduction and jurisdiction" (2014) 22(1) Fem Leg Stud 23.
} 
less attention to the theoretical and philosophical basis for it, or its ideal connection with workers' compensation. Arthurs, reflecting on the historical development of labour law, explains that "only when the promise of collective bargaining began to fade did we begin to look seriously at the alternatives, in particular at employment standards, health and safety, workers' compensation and discrimination statutes." 146 These topics fell in to what he refers to as the previously "unsexy field" of employment law, "unworthy of the attention of serious scholars", ${ }^{147}$ or what Fudge described as "labour law's little sister."148

Health and safety and workers' compensation have also developed in recent decades to become "technical specialities" influenced by engineering, occupational hygiene and organisational psychology, exacerbating the lack of theoretical attention. This isolation in to a specialist technical field has an ideological dimension to it, limiting the scope of what can be examined as a hazardous working practice, and limiting the ways in which workers can use health and safety laws to challenge the setting of working conditions. The neoliberal ideology pursued by New Zealand law makers in the 1990s particularly favours the recasting of these subjects as concerned with individualised "accidents", and primarily technical and compliance-focused in nature, rather than encouraging a wider examination of who is performing the work, under what conditions, or the needs of the humans performing it. This thesis argues that the goals of this project, and the goals of labour law, are better served by framing these areas within the wider relationships of work and giving the area greater theoretical attention.

\section{$V$ The Labour Law Aims of the Project}

The goals of labour law have been defined and redefined in various ways in the scholarship in recent years, as the field responds to its asserted "crisis." In Davidov's Purposive

\footnotetext{
${ }^{146}$ Harry Arthurs "Charting the boundaries of labour law: Innes Christie and the search for an integrated law of labour market regulation" (2011) 34(1) Dalhousie Law Journal 1, at 6.

${ }^{147}$ Above, at 6.

${ }^{148}$ Judy Fudge "Reconceiving employment standards legislation: Labour law's little sister and the feminization of labour [law]” (1991) 7 J L \& Soc Pol'y 73.
} 
Approach to Labour Law, he advances the "unique vulnerabilities of workers," 149 the "existence of democratic deficits" within organisations, ${ }^{150}$ power and efficiency, ${ }^{151}$ fulfilment of social and psychological needs, ${ }^{152}$ addressing systemic labour market failures, ${ }^{153}$ and the values of democracy, ${ }^{154}$ redistribution, ${ }^{155}$ social inclusion and citizenship, ${ }^{156}$ stability and security, ${ }^{157}$ and emancipation and social equality ${ }^{158}$ as possible goals of labour law. In re-evaluating the ends of labour law, the literature has also turned its attention to the philosophical basis for the law, with texts like Philosophical Foundations of Labour Law, published in late 2018, providing a recent treatment by a range of labour law scholars. ${ }^{159}$ In an article by Bogg, the philosophical perspectives of labour law are helpfully grouped in to four conceptions; power-based conceptions; wrong-based conceptions; rights-based conceptions and status-based conceptions. ${ }^{160}$

Power-based conceptions comprise the traditional framing of the philosophical basis of labour law, as outlined above, and focus primarily on the inherent inequality of bargaining power as the basis of the moral claim. ${ }^{161}$ Wrong-based conceptions focus on the specific wrongs of the relationship, such as the wrong of exploitation. ${ }^{162}$ Rights-based conceptions are concerned with the guarantee of certain fundamental human rights. ${ }^{163}$ Status-based

\footnotetext{
${ }^{149}$ Davidov, above at n 39 , at 35.

${ }^{150}$ At 38.

${ }^{151}$ At 40

152 At 43 .

${ }^{153}$ At 48.

${ }^{154}$ At 56.

${ }^{155}$ At 57.

${ }^{156}$ At 62.

${ }^{157}$ At 64.

${ }^{158}$ At 68.

${ }^{159}$ Hugh Collins, Gillian Lester and Virginia Mantouvalou Philosophical Foundations of Labour Law (Oxford University Press, Oxford, 2018).

${ }^{160}$ Alan Bogg "Labour, Love and Futility: Philosophical Perspectives on Labour Law (2017) 33 International Journal of Comparative Labour Law and Industrial Relations 7.

${ }^{161}$ Bogg, above, at n 160, at 10.

${ }^{162}$ Bogg, above at n 160, referring to Virginia Mantouvalou "The right to non-exploitative work" in Virginia Mantouvalou (ed) The Right to Work: Legal and Philosophical Perspectives (Hart, Oxford, 2015).

${ }^{163}$ Bogg, above, referring to Virginia Mantouvalou “Are Labour Rights Human Rights?” (2012) 3 Eur Lab LJ 151.
} 
conceptions are concerned primarily with equality in status, whether equality in autonomy ${ }^{164}$ or democratic equality. ${ }^{165}$ There is generally less literature specifically analysing the philosophical basis of health and safety and workers' compensation from these perspectives for the reasons discussed above. This thesis asserts that, as part of labour law, a project of health and safety and workers' compensation reform can, and should, be approached from the same philosophical perspectives. Using Bogg's four categories above, the project can be framed as follows.

\section{A Power-based conceptions}

First, it is possible to adopt a power-based conception of health and safety and workers' compensation. Inequality of bargaining power is evident in the fact workers routinely risk life and health in the performance of work for another's profit. Work-related injuries and illnesses are produced in a relationship of unequal power, where one party has the largely unfettered legal right to decide what work is performed, under what conditions, in what timeframes and with what tools, equipment or training. ${ }^{166}$ New Zealand workers can only refuse such work where there is "a serious risk" arising from "immediate or imminent exposure to a hazard" 167 and do not have the right to refuse "work that, because of its nature, inherently or usually carries an understood risk to the worker's health and safety." 168 Workers have little real power to influence decisions about the work they perform or the subsequent impact on their health and safety. While recent reforms in the HSWA are an improvement in many respects, the legislation continues to place decisions

\footnotetext{
${ }^{164}$ Horacio Spector "Philosophical Foundations of Labour Law" (2006) 33 Fla St U L Rev 1119, at 11441147.

${ }^{165}$ Judy Fudge "Labour as a 'fictive commodity': Radically Reconceptualising Labour Law” in Davidov and Langille, above at $\mathrm{n} 37$.

${ }^{166}$ There are some minimum standards for specific work tasks provided in the regulations like the Health and Safety at Work (General Risk and Workplace Management) Regulations 2016, Health and Safety at Work (Major Hazard Facilities) Regulations 2016, Health and Safety at Work (Asbestos) Regulations 2016, but for most hazards employers/PCBUs can determine for themselves what health and safety actions to take.

${ }^{167}$ Section 83(1), HSWA.

${ }^{168}$ Section 83(5).

61
} 
firmly in the hands of business with only relatively weak rights to be consulted or "engaged with" provided to workers. ${ }^{169}$

Reflecting this inequality in power, workers are typically the ones injured as a result of poor health and safety. Workers also have less power when attempting to seek redress for these consequences, as the experience of workers prior to the establishment of workers' compensation schemes illustrates. As discussed in the previous chapter, health and safety and workers' compensation were some of the first legal interventions, arising from the carnage of the industrial revolution and forming a core component of the early claims of organised labour. Workers' compensation can be seen as a fundamental part of the bargain between workers and business, and in a very real way, determines the boundary lines of the exercises of that power. Workers' compensation can be seen as providing for the weaker party where the inequality in bargaining power results in the costs of profit creation being borne by the worker. It can also be viewed as an attempt to address this, impacting on the bargain that can be entered into and limiting or permitting (through mandatory employer levies and enforcement) the extent to which employers can use their power to avoid the consequences of their activities.

The impact of the power imbalance between the parties is particularly apparent in relation to psychosocial hazards and the resulting stress-related health conditions, which are the focus of this thesis. Psychosocial hazards (e.g. stress, excessive work-loads, emotionally exhausting tasks or bullying) are the least regulated in New Zealand. There are few suitable inspection and enforcement tools provided in the new health and safety legislation, little priority for the area in enforcement policy and no ability to monitor employer performance. ${ }^{170}$ There is also very little ACC cover available for the health problems resulting from these hazards, facilitating and exacerbating the lack of health and safety standards. Employers in New Zealand have an almost unlimited capacity to determine remuneration structures, goals and targets, workloads, work allocations and task patterns,

\footnotetext{
${ }^{169}$ Part 3 Worker engagement, participation and representation.

${ }^{170}$ Dawn Duncan “A battle for hearts and minds: New Zealand's legal response to work-stress-related depression and cardiovascular disease" (2018) 43(3) NZJER 1.
}

62 
staffing levels, people management practices and organisational structures, and the frequency and processes of restructuring, despite the significant health consequences of these practices (discussed further in Chapter Five).

As discussed further in Chapters Four, Six and Seven, the ACC scheme plays a significant role in this area, with the lack of ACC cover resulting in a lack of data, the subsequent invisibility of these issues, the lack of evidence to support action, and the social perception that such risks fall outside the scope of employer responsibility. Exacerbating this, the position of WorkSafe is to encourage negotiated or mediated settlement where such issues arise. ${ }^{171}$ As discussed further in Chapter Four, New Zealand employers have little meaningful incentive to choose worker health over profits and are provided a free and confidential mediation service with which to "exit-package" any individuals affected or raising complaints.

ACC also plays a part in the way the power imbalance between business and workers manifests itself, in terms of hazard recognition, what is considered a reasonable response to an identified hazard, and the employee's legal abilities to address the issues individually or collectively (discussed further in the following chapters). The imbalance in bargaining power is particularly acute in relation to worker mental health and chronic stress-related illnesses. As explained in greater detail in Chapter Five, chronic mental and physical health problems arise over a long period of time, involving the complex interplay of biological, social and economic factors. Employer decision-making on workloads or staffing levels, which is focused on short-term profitability, can have significant and compounding consequences for worker mental health.

This is a particular issue given the chronic under-criminalisation of work health and safety offences generally. ${ }^{172}$ Schindeler and Ransley look at the "normalising and neutralising"

\footnotetext{
${ }^{171}$ See the most recent statement in WorkSafe New Zealand Bullying at Work: Advice for Workers (WorkSafe New Zealand, 2017) <http://www.worksafe.govt.nz/the-toolshed/tools/bullying-preventiontoolbox/\#page=15>

${ }^{172}$ See Diego Canciani The politics and practice of occupational health and safety law enforcement (e-book, Palgrave MacMillan, 2019); Steve Tombs and David Whyte "A deadly consensus: Worker safety and regulatory deregulation under New Labour” (2009) Brit J Crim 52(5) 997; and Steve Tombs and David Whyte
} 63 
of health and safety offending, and the particular impact on psychological injuries in Australian law. ${ }^{173}$ They argue that the prioritisation of risks for employers and regulators is influenced by the broader environment in which the regulation operates.: ${ }^{174}$ Hawkins argues that decisions on whether and how to enforce the law are ultimately determined on the basis of a moral and political commitment or ambivalence to the risk and the problems. $^{175}$ ACC has a significant impact on the perception of risk and on the "reasonableness" of actions taken in response to that risk. As discussed further below, the construction of injuries and illnesses as "accidents" rather than moral wrongs impacts on the health and safety enforcement practices.

\section{B Rights-based conceptions}

Health and safety and workers' compensation can also be approached from a rights-based perspective. New Zealand workers have rights in domestic law, and under international human rights instruments, to safe and healthy working conditions and fair compensation. Workers have an explicit statutory right under the HSWA to protection from "harm to their health, safety, and welfare" 176 and the legislated rights have been recognised as operating as an implied term of contract giving rise to a range of potential claims. ${ }^{177} \mathrm{New}$ Zealand has also ratified ILO Conventions 12, 17 and 32 in relation to compensation, and 134 and 155 in relation to injury prevention and occupational health and safety. These conventions have been incorporated in to national law. ${ }^{178}$

Regulatory surrender: Death, injury and the non-enforcement of law (Institute of Employment Rights, Liverpool, 2007).

${ }^{173}$ Emily Schindeler and Janet Ransley "Normalising and neutralising offending- The influence of health and safety regulation" (2015) 26(3) Current Issues in Criminal Justice 305.

${ }^{174}$ Schindeler and Ransley above at n173, at 307.

${ }^{175}$ K Hawkin "Compliance strategy, prosecution policy and aunt Sally: A comment on Pearce and Tombs" (1990) 30(4) British Journal of Criminology 444.

${ }^{176}$ Section 3, HSWA.

${ }^{177}$ Attorney-General v Gilbert, above at $\mathrm{n} 19$.

${ }^{178} \mathrm{~A}$ list of current ILO conventions ratified by New Zealand can be accessed on the MBIE website $<$ http://www.mbie.govt.nz/info-services/employment-skills/international-services/document-imagelibrary/international-labour-conventions-ratified-by-nz.pdf> 
It is possible to conceive of the right to health and safety as a fundamental human right. ${ }^{179}$ It has been suggested that "the human rights movement and the labo[u]r movement run on tracks that are sometimes parallel and rarely meet." ${ }^{180}$ Labour rights are often treated as separate from human rights. ${ }^{181}$ Mantouvalou argues, however, that human rights law can offer important insights to the critical development of labour law, ${ }^{182}$ with human rights becoming the "lingua franca of global moral though." 183 There is a growing literature on "labour rights as human rights." 184 According to Hilgert, health and safety at work is commonly described as "a basic human right," and has been such since the dawn of the modern human rights era. ${ }^{185}$ Building on the right to "just and favourable conditions of work" under Art 23 of the Universal Declaration of Human Rights, the International Covenant on Economic, Social and Cultural Rights (ICESCR) Art 7(b) provides workers with a right to "safe and healthy work", and also to support for workers and their dependants following an injury or illness under Art 9. Art 12 provides a right to the "highest attainable standard of physical and mental health," and requires states to improve "all aspects of ...industrial hygiene," prevent, treat and control occupational diseases and create conditions to ensure "medical attention in the event of sickness."

Nearly 80 per cent of ILO instruments relate to work health and safety in some way, but its characterisation by the ILO as a "fundamental human right" has a mixed history. Work

\footnotetext{
${ }^{179}$ Paul Roth "Chapter 13 Economic Rights: Workplace Rights and the Right to Social Security" in Margaret Bedggood (ed) Human Rights Law in Aotearoa New Zealand (Thomson Reuters, Wellington, 2017).

${ }^{180}$ VA Leary “The Paradox of Workers' Rights as Human Rights" in LA Compa and SF Diamond (eds) Human Rights, Labor Rights, and International Trade (University of Pennsylvania, Philadelphia, 1996), at 22.

${ }^{181}$ See K Kolben “Labor Rights as Human Rights?” (2010) 2 Va J Int'l Law 449.

${ }^{182}$ See Virginia Mantouvalou, above at n 162 and 163.

183 "Human Rights as Idolatry" in Amy Gutman (ed) Michael Ignatieff: Human Rights as Politics and Idolatry (Princeton University Press, Princeton 2001).

${ }^{184}$ See Philip Alston Labour Rights as Human Rights (Oxford University Press, Oxford, 2008).

${ }^{185}$ See discussion in Jeffrey Hilgert "The future of workplace health and safety as a fundamental human right” (2013) 33 Comp Lab Law \& Pol’y J 715.

${ }^{186}$ ICESCR, Art 12.
}

65 
health and safety is excluded from the "human rights" in some core ILO Declarations, ${ }^{187}$ but included in others, such as the Istanbul and Seoul Declarations on Safety and Health at Work. ${ }^{188}$ In the Istanbul Declaration it was stated that: ${ }^{189}$

...promoting the rights of workers to a safe and health working environment should be recognised as a fundamental human right.

Roth argues that when implementing the rights contained in the ILO conventions and in the ICESCR, there is: 190

...considerable overlap in approach, and the two sources of workplace rights and accountability mechanisms are in practice integrated and monitored in the UN treaty system and the General Assembly's (UNGA’s) Human Rights Council.

As discussed further below, the "why" of health and safety and workers' compensation matters a great deal. Casting something as a fundamental human right accords it a greater moral status than a welfare entitlement, regulatory requirement or compliance cost, and introduces a greater focus on the human being rather than the efficiency of loss control mechanisms.

\section{Wrongs-based conceptions}

Taking a wrongs-based conception of health and safety and workers' compensation is also possible, with health and safety breaches of course being criminal offences. The "wrong" can be conceived of as existing in the breach, either of the human right, statute or the implied obligations of the relationship, or in the harm done, being the death, injury or illness and its associated costs. A moral wrong occurs in the causing of the worker's death

\footnotetext{
$\overline{187}$ See for example, the ILO Declaration of the Fundamental Principals and Rights at Work (1999) 6 IHRR 285 and the ILO Declaration on Social Justice for a Fair Globalisation UNGA63 2008.

${ }^{188}$ Istanbul Declaration on Safety and Health at Work (signed 11 September 2011), available at: $<$ https://www.ilo.org/global/meetings-and-events/events/world-congress-on-safety-and-health-atwork/lang--en/index.htm>; Seoul Declaration on Safety and Health at Work (signed June 29, 2008), available at: <http://www.seouldeclaration.org/>

${ }^{189}$ Istanbul Declaration, at para 1.

${ }^{190}$ Roth, above at n 179, at 614.
} 
or incapacity in breach of a duty not to do so. This breach limits the worker's quality of life and/or earnings potential, reducing the ability of that person to enjoy an expected standard of living and participate in economic, social, cultural and family life. The wrong could also be framed as exploitation and unacceptable risk-shifting behaviour, with those that control work moving the risks of that work on to people unable to protect their own interests or to society at large.

There is a particular moral wrong which exists in the creation of profit through the shifting of risks and losses to others. This link between profit creation through harm done and loss caused to others operates in a number of areas of law to increase moral culpability, such as vicarious liability and the remedy of unjust enrichment. ${ }^{191}$ The ACC scheme could operate to help in correcting this wrong in a number of ways. First, ACC could help to ensure the visibility of injuries and illnesses suffered by workers in the pursuit of profit. Improved visibility allows for the harm done to receive due moral and legal condemnation. Second, ACC could ensure workers injured or made ill are economically provided for, rehabilitated and returned to health. Third, ACC could play a role in making employers liable (even of not directly) for the losses suffered by workers and their families. Fourth, ACC could help to prevent the injuries and illnesses from occurring in the first place, by helping researchers, unions and the regulator better understand the injuries and illnesses and take action.

As discussed later in this chapter, conceiving of work-related injuries and illnesses as a moral wrong or criminal offence, rather than an economic loss or unavoidable consequence of beneficial activity, changes the way those harms are viewed and how the ACC scheme operates to impact on work health and safety. For example, Johnstone argues that: ${ }^{192}$

[t]here has also been a strong tendency to regard the sanctions in the work health and safety statutes as not being 'really criminal'. This has been reinforced by a trend to prosecute mainly in response to incidents resulting in death or serious injury, so that offences have been 'individualised' and 'decontextualised' in a way that has enabled employers to reduce their culpability. I also suggest that work health and safety has been decriminalised in a second sense, in that the mainstream

\footnotetext{
${ }^{191}$ See Ernest J Weinrib “47. Unjust enrichment" in Dennis Petterson (ed) A companion to philosophy of law and legal theory (Blackwell, Online, $2^{\text {nd }}$ ed, 2010).

192 Richard Johnstone "Work health and safety and the criminal law in Australia" (2013) 11(2) Policy and Practice in Health and Safety 25, at 26.
} 
criminal law is generally not used to punish employers and managers highly culpable for workplace death and serious injury.

Although writing about the situation in Australia, the same could equally be said of New Zealand's work health and safety enforcement responses. The Supreme Court decision in Osborne and Rockhouse $v$ WorkSafe also suggests the regulator does, or at least did, see health and safety offences as somehow lesser or different to other areas of criminal conduct. ${ }^{193}$ As discussed further in Chapters Six and Seven, the ACC scheme impacts on the behaviour of those engaging workers, and those enforcing the law, with the boundaries of the ACC scheme influencing the perceived boundaries of liability and moral responsibility.

\section{Unequal status and dignity}

Finally, applying Bogg's categories, health and safety and workers compensation can be framed as an issue of unequal status and dignity. For Sinzheimer, and recent theorists such as Gilabert, human dignity is conceived of as one of the main goals of labour law, recognising that human dignity can be endangered by employment. ${ }^{194}$ In relation to workplace injury and illness this "endangerment" is in the literal sense. The ability for individuals to fully enjoy and participate in life is denied when incapacitated by injury and illness or poverty and social exclusion following. As discussed further in Chapter Seven, the ACC scheme has a very real effect on the dignity of workers injured or made ill through work. Dignity can be promoted through the provision of earnings compensation, allowing for the worker to enjoy broadly the same quality of life for them and their families, and also in access to rehabilitation and other support. Dignity is also promoted by improving the conditions of the work, preventing harm to the health, safety and mental wellbeing of the workers.

193 [2017] NZSC 175; [2018] 1 NZLR 447.

${ }^{194}$ Hugo Sinzheimer "Das Wesen des Arbeitstrechts" (1927) in Hugo Sinzheimer Arbeitsrecht und Rechtssoziologie vol 1 (Bund Verlag, 1976) $108 \mathrm{ff}$, at 110. 
Human dignity can be undermined when the law allows for human beings to be treated as expendable widgets of profit creation. Sinzheimer emphasised that the "object in transaction in an employment relationship is not a commodity but the human being as such." 195 It follows then that the labour market is not a market like any other, or as put in the first principle of the Philadelphia Declaration: "labour is not a commodity." 196 Applied to workers' compensation and health and safety "labour is not a commodity" suggests the law ought to proceed on the basis that human beings are not units of production permitted to be physically or mentally spent or destroyed when economically advantageous. Following from this approach, the human being, and the health of their bodies and minds, ought to be the paramount goal of such laws.

Relevant to this approach are the principles of equity and "equality in status". The distribution of work-related injury and illness is not random, with those the most disadvantaged in society typically also the most likely to be injured or made ill through work and the least able to advance their interests or seek legal redress. ${ }^{197}$ New Zealand research highlights this effect on Māori workers and recent migrants. ${ }^{198}$ As discussed further in the following chapters, a worker's risks of sustaining an injury or illness reflects the types of hazards they are exposed to. The type of hazards a worker is exposed to depends on the particular type of work, and the way that work is organised and managed. The types of work people perform and the types of hazards they are exposed to vary across different segments of society.

As discussed further in Chapter Four, the gaps in ACC cover fall disproportionately on female-dominated occupations and forms of work that impose higher mental and emotional loads. The mental health costs of work are particularly significant, not only for the size of

\footnotetext{
${ }^{195}$ Hugo Sinzheimer, above.

${ }^{196}$ International Labour Organisation, Declaration concerning the aims and purposes of the International Labour Organisation (Declaration of Philadelphia) (10 May 1944).

${ }^{197}$ Research on this discussed in detail in Chapter Four and Five.

${ }^{198}$ Amanda Eng, Andrea't Mannetje, Lis Ellison-Loschmann, Dave McLean, Soo Cheng and Neil Pearce "Ethnic differences in patterns of occupational exposures in New Zealand" (2011) 54 American Journal of Industrial Medicine 410.
} 
the economic impact on New Zealand, but also its patterns of distribution. ${ }^{199}$ The recent OECD report found that:200

\begin{abstract}
As a population group, Māori people experience the greatest burden due to mental health issues of any ethnic group in New Zealand. The issues of mental health and work are further compounded by other disadvantages including poorer skills and an unemployment level twice the national unemployment figure.
\end{abstract}

As discussed further in Chapter Five, workers in more precarious segments of the labour market are also more likely to suffer mental health problems and less likely to be able to access support through ACC. Ensuring the reforms proposed offer meaningful protection to workers in the current and shifting labour market requires these issues to be acknowledged and addressed.

\title{
E Summarising the goals for the project
}

As set out above, the project aims to reform the ACC scheme to do two things. First, to provide better compensation for work-related health problems in New Zealand. Second, to contribute to improved work health and safety. As explained above, these goals can be better understood, and better achieved, when informed by clear theoretical principles and an examination of why those ends are sought. Drawing on Davidov, Bogg and others above, the goals for the project can be articulated as below.

\section{a. Addressing the inherent inequality of bargaining power}

Work-related injuries and illnesses arise from a unique context characterised by unequal power relations, where employers (or others in their place) control the work performed, by whom and how, the risks workers are exposed to, and the resources available to address those risks. For the scheme to achieve better compensation and health and safety, this context and its contribution to injury and illness must be acknowledged.

${ }^{199}$ OECD, above at n 10.

${ }^{200}$ Above, at 37. 
Power imbalances can be addressed in several ways. First, power imbalances can be addressed by ensuring that employers bear the consequences of their decisions even if indirectly through levies collection. Second, easy to access treatment, earnings compensation, and rehabilitation helps to ensure a lack of power and resources do not prevent access to essential support. Third, legal protection from harm should operate as an implied term in every contract of employment, which employers cannot avoid or contract out of. Fourth, power imbalances can be addressed by ensuring the public visibility of the harm and its costs through an open and transparent process (rather than confidential mediation) and the provision of public information about work-related injuries and illnesses. Fifth, the collection and analysis of health and safety focussed data enables good health and safety policy and enforcement practices to be developed. Sixth, information on health hazards arising from the terms and conditions of work in a given industry is made available to workers and their unions so collective action can be taken.

\section{b. Recognising the rights of workers}

The goals can also be understood better as a means of recognising the rights of workers to work that is safe and without risks to health, and to fair compensation for the health problems arising from the breaches of those rights. New Zealand workers have rights under domestic law and international labour rights and human rights instruments. Framing workrelated injuries and illnesses as a breach of a worker's legal rights by their employer, or the Government's breach of its obligation to protect fundamental human rights, creates a very different set of starting assumptions to the current framing of injuries and illnesses as an "accident" like any other, or an unavoidable and acceptable loss to be efficiently spread (discussed further below).

\section{c. Framing work-related injuries and illnesses as wrongs not accidents}

This is the case also if starting from the assumption that such injuries and illnesses constitute moral and legal wrongs done to workers. While health and safety offences are criminal they are often not treated as "real crimes" or deserving or public condemnation. Characterising work-related injuries and illnesses in terms of a "wrong" done to workers 
carries a different set of connotations and creates a different set of reform imperatives to characterising them as "accidents." Starting with the assumption that a work-related health problem arises from wrongful conduct also impacts on people's perceptions of the role of the compensation scheme in relation to other parts of the country's health and safety response.

\section{d. Promoting equity and dignity in the treatment of workers}

Another important goal for the project is ensuring the equity and dignity of all workers with work-related injuries or illnesses. The scheme should ensure fair, equitable and comprehensive cover to all workers, recognising that work-related injury and illness patterns vary by gender, class and ethnicity, and ensuring all workers are able to return to health and participation in life to the fullest extent possible.

As discussed further below, these principles form the first step in the purposive method, allowing for both the evaluation of current and future problems and the development of a reform proposal.

\section{Improved Health and Safety- The Ends also Justify the Scope}

To achieve the goals set out above, this thesis is confined in scope to the cover of workrelated injuries and illnesses. A key assertion in this thesis is that ACC should play a positive role in work health and safety, contributing to the prevention of injuries and illnesses, not just compensating them. Work-related injuries and illnesses arise in a different social, economic and political context to other incapacities, that requires a different set of responses to ensure effective prevention. A narrower scope enables the unique needs of work-related injury and illness prevention to be recognised and to drive the development of the reforms proposed. A narrower scope is also more consistent with the labour law approach taken. 
Labour law is sometimes described as taking a "sociological approach"201 to health and safety. The sociological categorisation refers to a number of strands of research in law and the social sciences that focus on the social relations of work as the determining factors in the injuries and illnesses suffered by workers. Sociological and socio-legal analyses tend to start from the assumption that work-related health problems are socially produced, with an emphasis on political economy, and the way the situations in which injuries occur are structured by broader economic and political relations. ${ }^{202}$ Work-related injuries and illnesses are viewed as arising from a social and political system, and not as "accidents," the product of apathy ${ }^{203}$ or the "inevitable materialisation of risks inherent in production." ${ }^{204}$ As set out by Quinlan, Bohle and Lamm, health and safety problems: ${ }^{205}$

...entail a complex set of socially constructed or arranged physical features and physical, chemical, social and individual interactions. The presence of a particular chemical or machine in the workplace and the associated risk is mediated by an often long and complex web of human decisions- decisions by factory and equipment designers, manufacturers, employers, regulators and a host of others.

Johnstone, Bluff and Clayton explain that: ${ }^{206}$

The factors which lead to an increased risk of worker injury include unusual schedules of work; forms of work that encourage excessive workloads or work rates, de-skill workers or limit worker autonomy to make decisions about their own safety; incentive payment schemes which encourage workers to work too quickly and hence unsafely; overly bureaucratic organisations; authoritarian management; an overriding emphasis on production schedules; and the outsourcing and fracturing of work processes.

Recognising the economic and political context, the social constructions of work, and the socio-political language and meanings given to occupational health problems is especially important given the focus of this thesis on chronic stress-related health problems. Longterm or complex health effects caused by a person's work, including depression, anxiety,

\footnotetext{
${ }^{201}$ Johnstone, Bluff and Clayton, above at n 53; See also Michael Quinlan "Psychological and sociological approaches to the study of occupational illness: A critical review" (1988) 24(2) ANZJS 189.

202 See Theo Nichols The Sociology of Industrial Injury (Mansell Publishing, London, 1997). Discussed further in Chapter Four in relation to the social and cultural meanings of "accident".

${ }^{203}$ Robens Report, above at n 42.

${ }^{204}$ Glasbeek, above at n 43.

${ }^{205}$ Michael Quinlan, Philip Bohle and Felicity Lamm Managing Occupational Health and Safety: A multidisciplinary perspective ( $3^{\text {rd }}$ ed, Macmillan, South Yarra, 2010), at 25.

206 Johnstone, Bluff and Clayton, above at n 53, at 86.
} 
drug and alcohol abuse, pain syndromes, heart disease and cancers, often sit at the end of a complex set of relationships that the term "accident" does little justice to.

As discussed further below, this thesis does not seek to oppose any future expansion of ACC cover to incapacities arising in non-work contexts. The ACC scheme is due considerable reform, not only in relation to worker health, but many other aspects of cover, and also many operational and funding issues. This thesis seeks to contribute to debates about the future of the ACC scheme by focusing on the unique issues and needs of workers with work-related health problems. As discussed in previous chapters, this is an area of particular scholarly neglect in New Zealand that warrants special attention.

\section{A Is ACC reform the best place to seek improvements to worker health and safety?}

It could be argued that $\mathrm{ACC}$ reform is the wrong place to seek an improvement to work health and safety, and efforts would be better directed to changing the HSWA or increasing the power of workers through the strengthening of collective bargaining. While reforms in these areas are a necessary part of improving New Zealand's health and safety, they are not sufficient on their own, and the impact of the ACC scheme on work health and safety should not be underestimated. The role of ACC in New Zealand's health and safety performance is an area rarely discussed and often avoided for fear of reigniting the political desire to privatise the scheme.

As will be discussed further in Chapters' Four and Six, the ACC scheme has a powerful impact on the way work-related health problems are understood and spoken about, and the behaviour of actors in preventing and responding to them. When seeking to address the "tragic paradox" of chronic health problems in New Zealand, ACC reform can be seen as an important first step, making the health conditions, and the true costs to workers, society and the economy visible to policy makers. This visibility, and the economic security provided to workers (who would otherwise need to take legal action), contributes to other

areas of labour law, providing data for regulator action and strengthening the bargaining 
position of unions seeking to change working terms and conditions that negatively impact on health.

New Zealand's unique historical context also makes it important to approach ACC as part of the legal response to work health and safety. As set out above in Chapter Two, and discussed further in Chapter Four, New Zealand's old workers' compensation regime was replaced by ACC, separating workers' compensation from work health and safety with real negative consequences in the decades that followed. New Zealand has one of the worst health and safety records in the developed world. While the reasons for this are complex and interrelated, ACC is a significant and often overlooked contributor.

\section{B Why not seek to address the problems through collective bargaining?}

One of the fundamental principles in the labour law literature is the importance of collectively wielded labour power, primarily through bargaining. This thesis does not propose a collective bargaining solution to the problems of chronic work-related ill health for several reasons. First, collective employment agreement coverage now sits at about 17 per cent in New Zealand. ${ }^{207}$ For the vast majority of employees, and large numbers of nonemployee workers, there is little prospect of addressing the issues through bargaining. Some unions have made significant recent advances in this area, for example, the New Zealand Nurses Organisation Multi-Employer Collective Agreement (MECA) with the District Health Boards. ${ }^{208}$ There also seems to be a recent rise in health and safety related industrial action on the back of the HSWA union campaigns. For example, the New Zealand Resident Doctors' Association (NZRDA) has engaged in a series of strikes to change roster patterns on the grounds of health and safety, as the doctors were required to work seven ten-hour night shifts in a row, or 12 day shifts with a maximum of 16 hours per

\footnotetext{
${ }^{207}$ Latest Household Labour Force Survey data can be accessed on the Statistics New Zealand website $<$ https://www.stats.govt.nz/information-releases/labour-market-statistics-march-2019-quarter>

208 The New Zealand Nurses' Organisation District Health Board Multi-Employer Collective Agreement can be accessed on the NZNO website <https://www.nzno.org.nz/dhb $>$
} 
shift. ${ }^{209}$ The ongoing teacher strikes have been driven by claims of burnout and mental illness, ${ }^{210}$ as was the strike by general staff at Auckland Hospital. ${ }^{211}$

Despite recent victories through industrial action and collective bargaining, there are significant hurdles to achieving the desired reform in this way. Looking historically, even where unions do have the bargaining power to make changes, addressing the chronic health effects of work has often proven to be less of a priority than wage gains or job security. Unions have always, in the course of bargaining, been forced to make trade-offs, and improvements to health and safety (especially where health effects are delayed or the evidence is complex and inconclusive) are often traded off for more immediate wage gains for members. ${ }^{212}$ Walters looked at the potential for unions to address chronic health problems through organising activities and concluded that unions face particular difficulties in this area, with: ${ }^{213}$

...the wider structural and organisational contexts involved act[ing] to disadvantage the practice of worker representation in relation to psycho-social risks.

Empirical studies also highlight the fact that workers are rarely able to correctly factor in the risk of developing a long-term disease in to the negotiated price of labour. ${ }^{214}$ The

\footnotetext{
${ }^{209}$ See Press Release "Doctors Denied Safer Hours" (18 August 2016)

$<$ http://www.asms.org.nz/news/other-news/2016/08/18/doctors-denied-safer-hours/> See also Isobel Ewing “Overworked Doctors Making Mistakes with Patients - Survey" (17 August 2016)

$<$ http://www.newshub.co.nz/politics/overworked-doctors-making-mistakes-with-patients---survey2016081716>

${ }^{210}$ Josephine Franks "Teachers' strike: Burnt out, depressed, disillusioned - the staff quitting the classroom" (29 May 2019) Stuff < https://www.stuff.co.nz/national/education/113074836/teachers-strike-burnt-outdepressed-disillusioned--the-staff-quitting-the-classroom>

${ }^{211}$ Shabnam Dastgheib “Auckland health workers begin strike action” (10 Nov 2015) Stuff

$<$ http://www.stuff.co.nz/auckland/73859230/Auckland-health-workers-begin-strike-action>

${ }^{212}$ Breen Creighton and Neil Gunningham The Industrial Relations of Occupational Health and Safety (Croom Helm, Sydney, 1985).

${ }^{213}$ David Walters "Worker representation and psycho-social risks: A problematic relationship?" (2011) 49 Safety Science 599, at 600.

${ }^{214}$ See James C Robinson "Hazard pay in unsafe jobs: Theory, evidence, and policy implications" (1986) 64(4) The Millbank Quarterly 650. Peter Doman Markets and Mortality: Economics, Dangerous Work, and the Value of Human Life (Cambridge University Press, Cambridge, 1996).
} 
"danger money" effect only operates in relation to immediate risks. ${ }^{215}$ Chronic health problems are an acknowledged area of "market failure." Even the right-wing think-tank the Rand Institute, writing in the 1980s, considered contract and common law inappropriate for dealing with cases of long-lead in time occupational disease. ${ }^{216}$ Economic research has established that the costs of occupational diseases simply cannot be accurately incorporated within the correct "price" of goods and services, as the gap in time between the disease, subsequent litigation for compensation and price setting mechanisms was too great. ${ }^{217}$

As discussed above, inequality of bargaining power can operate to prevent workers seeking justice. Employers with more resources, can prolong legal action or change the legal identities of businesses. Given the current nature of individualised employment relations, the weakened state of trade unions in New Zealand and limited collective agreement coverage, as well as the particular difficulties in responding to chronic illness through bargaining or litigation, a universal and regulated improvement to the ACC scheme is asserted to be the best approach to achieving the aims of the project.

\section{Why not just enact the full Woodhouse Report vision?}

As discussed in Chapter Two, Woodhouse and fellow reformers sought the eventual expansion of the scheme to "all the hazards of modern living" including diseases. ${ }^{218}$ There have been recent calls in New Zealand to enact fully comprehensive social insurance cover. This thesis does not approach law reform from this perspective, and instead seeks to ensure the unique needs of work-related injuries and illnesses can be met, with a particular focus

\footnotetext{
${ }^{215}$ Above.

${ }^{216}$ See most recent statements in Michael Dworsky and Nicholas Broten "How can workers' compensation systems promote occupational health and safety" (2018) and subject matter archive for Rand Institute/Corporation opinions $<\mathrm{https}$ ://www.rand.org/pubs/research_reports/RR2566.html $>$ most recent ${ }^{217}$ See Michael J Moore and W Kip Viscusi Compensation mechanisms of job risks: Wages, workers' compensation and product liability (Princeton University Press, Princeton, 1990); See also Michael Dorman "The economics of safety, health and wellbeing: An overview" (May 2000) prepared for the ILO Infocus Programme on Safe Work <https://www.ilo.org/wcmsp5/groups/public/---ed_protect/---protrav/--safework/documents/publication/wcms_110382.pdf>

${ }^{218}$ Woodhouse Report, at 3.
} 
on prevention and contributing to wider improvements in the terms and conditions of work. The interaction of the reforms proposed with the other ACC functions and the impact on the wider scheme is discussed in Chapters Six, Seven and Eight.

While enacting the full Woodhouse Report vision would see an expansion in the available cover, it would not achieve the goals of prevention sought, and may operate to undermine them, as Woodhouse himself was acutely aware in the Woodhouse Report. ${ }^{219}$ The introduction of the ACC scheme in the 1970s saw the provision of compensation to a wide variety of non-work injuries and illnesses. While this was a great benefit to workers who were injured outside of work, it also came with real costs and consequences for both the prevention and compensation of work-related harm in the decades that followed. As discussed below, there are important differences in assumptions and goals between workers' compensation and social security provision, and there are trade-offs required to be made between the goals of universal social security and the needs of work health and safety. In developing a reform proposal, this thesis seeks to identify and challenge some of the social insurance assumptions which have operated to undermine health and safety in the ACC scheme, allowing for future iterations of the scheme to be designed to make a positive contribution to work health and safety.

When the ACC scheme was proposed in New Zealand, and then in Australia, organised labour fought against its introduction as a replacement for workers' compensation. Unions in other common law countries have also fought the "welfarisation" of workers' compensation. ${ }^{220}$ While this has typically been dismissed as "patch protection" a closer analysis reveals a solid theoretical basis for the opposition. ${ }^{221}$ Despite some shared history between the labour law and social welfare reform agendas, the ends sought and the focus

\footnotetext{
219 At 5 .

${ }^{220}$ See Robert Story “Social assistance or a worker's right: Workmen's compensation and the struggle of injured workers in Ontario, 1970-1985" (2006) Studies in Political Economy 78 for a discussion of Canadian workers; See Nolan, above at n 56, in relation to Australia; and see also Gregory P Guyton "A brief history of workers compensation" (1999) 19 Iowa Orthop J 106.

${ }^{221}$ See Peter McKenzie "The compensation scheme no one asked for: The origins of ACC in New Zealand (2003) 34 VUWLR 193; See also Macmillan, above at n 55.
} 
and basis of the claim to compensation are very different. ${ }^{222}$ Davidov himself recognises this when stating: ${ }^{223}$

[a]dmittedly, when we think about reforming welfare state programmes we have to be aware of changes in the labour market and take the rights and benefits secured by labour law (or not secured) into account. Thus, for example, if we are interested in achieving economic security, this can be done by a combination of labour laws and social security laws; so the two fields must be coordinated. However, this does not mean that the fields become one. At a high level of generality the goals may be the same, but there are also more specific, separate goals (such as those related to redressing the inequality of power between employer and employee), as well as very different structures and techniques.

As Davidov suggests, it is important that welfare provision and labour law are coordinated, as they interact with each other, but they should not be treated as one. At a high level of generality, both areas can be viewed as seeking to achieve a fairer and more just society for working people, redistributing wealth and ameliorating the vicissitudes of the market. At this level, ACC can be viewed as part of the State's intervention in the market to ensure a minimum standard of care for citizens incapacitated and unable to work. However, the provision of workers' compensation and the provision of welfare are not the same thing, and failing to recognise the important differences in the goals sought by the two areas, and the important differences in the means needed to give effect to those specific goals, risks undermining them both. As discussed further in the next chapter, the assumptions underpinning the universal provision of compensation for "accidents" has had a serious negative impact on work health and safety.

This thesis asserts that workers' compensation ought to be viewed as part of labour law. Although coinciding with calls for social and public health reform in the late $18^{\text {th }}$ and early $19^{\text {th }}$ centuries, workers' compensation was part of the battle between capital and labour over the conditions of work, linked both practically and conceptually to work health and safety. ${ }^{224}$ This was true in New Zealand around the time of the first statutory workers'

\footnotetext{
$\overline{{ }^{222} \text { Many European countries have models with a greater level of integration, following a different pattern }}$ of historical development.

${ }^{223}$ At 7.

${ }^{224}$ Bob Barnetson The Political Economy of Workplace Injury in Canada (Athabasca University Press, ebook, 2010).
} 
compensation schemes. ${ }^{225}$ Following the 1890 waterfront strikes, and the public outcry over mining and factory disasters, the 1900 legislation is considered to have been introduced primarily to ensure the "industrial peace." ${ }^{" 26}$ Occupational health and safety issues are often galvanising political events and industrial trigger points. Statutory workers' compensation was introduced alongside factories regulations, compulsory arbitration and a labour inspectorate for good reason. As set out above, effectively preventing work-related injuries and illnesses requires a combination of specific working standards, strong worker representation, good enforcement practices, and a well-designed workers' compensation provision. ${ }^{227}$ Organised labour sought a package of reforms with workers' compensation a central plank.

The legal and political arguments for workers' compensation, being part of the organised labour agenda, were very different to the arguments for welfare provision. Arguments for social welfare tend to be rooted in concepts of siamo tutti fratelli (we are all brothers), citizens in social compact with the state, a moral appeal to notions of a just society and common humanity. ${ }^{228}$ The relationship of the worker to the person hiring them is a much more direct, contractual and personal one, than the relationship of citizen to state or between fellow citizens. ${ }^{229}$ There is also a much more direct relationship between profits created and the efforts of the workers, a more direct common relationship between workers in a workplace, and accordingly a stronger basis and mechanism for demanding a greater share of the wealth created and improved conditions of work. This difference is especially important for health and safety and workers' compensation. Decisions about who performs work, under what conditions and the level of risk "acceptable" in the performance of that work has a direct impact on both the profitability of that business, and also the harm suffered by those performing that work.

\footnotetext{
${ }^{225}$ Nolan, above at $\mathrm{n} 56$; Purse and Guthrie, above at $\mathrm{n} 52$; Palmer, above at $\mathrm{n} 50$; and Easton, above at $\mathrm{n}$ 57.

${ }^{226}$ See Stevan Eldred-Grigg New Zealand Working People 1890-1990 (Dunmore Press, Palmerston North, 1990); and Erling Rasmussen and John Deeks Employment Relations in New Zealand (Pearson, Auckland, 2009).

${ }^{227}$ Johnstone, Bluff and Clayton, above at n 53; See also Creighton and Gunningham, above at $\mathrm{n} 212$.

${ }^{228}$ See Sharp and Kunowski, above at $\mathrm{n} 88$.

${ }^{229}$ See Anderson, Brodie and Riley, above at n 116.
} 
The industrial relationship is also politically different. The early political economy of workers' compensation is argued to have delivered a direct political and economic benefit to all parties. Workers traded off their rights to sue in return for greater certainty and efficiency in obtaining compensation. ${ }^{230}$ Employers agreed to bear some portion of the injury costs across an industry in return for stability, certainty of costs and the removal of litigation risk. The government achieved greater economic stability and legitimacy amongst voters. ${ }^{231}$ Because of these differences the argument for workers' compensation is typically stronger than for welfare provision. This was a fact Woodhouse himself was clearly aware of in the Woodhouse Report as the basis of his claim for expansion was reasoning by analogy with the compensation available for workplace injury and illness. His argument for reform hung on readers first accepting the place of workers' compensation as unchallengeable, even if not optimally performing, and then arguing the similarities in the incapacities suffered.

Woodhouse argued that "[i]njury, not cause, is the issue." 232 This argument runs that a broken leg is a broken leg however caused, and it is the suffering of such an incapacity which provides the basis for the claim to compensation. However, the argument put forward by Woodhouse requires viewing the workers' compensation functions in isolation, and ignoring the industrial relations of workplace injury and illness. Divorcing workers' compensation from other aspects of labour law and viewing workers' compensation functions as being akin to social security provision creates significant problems, including the misalignment of goals and means identified by Davidov. Social insurance thinking, which influenced Woodhouse, was based on the belief in community responsibility and a claim that we should "all share in sustaining those who become the random but statistically necessary victims" of "community activities."233 Writing in 1977, Woodhouse stated:"234

The responsibility for accidents is not only the responsibility of the individual who caused the accident. Society itself has built up and encouraged heavily risk-laden activities that exact a known and expected

\footnotetext{
${ }^{230}$ Barnetson, above at Error! Bookmark not defined., and Rassmusen and Deeks, above at n 226.

${ }^{231}$ Barnetson, above.

${ }^{232}$ Woodhouse Report, at 20.

${ }^{233}$ Woodhouse Report, at 39.

${ }^{234}$ Owen Woodhouse "Aspects of the Accident Compensation Scheme" [1979] NZLJ 395, at 396.
} 
cost in life and limb. It is imperative therefore that society share in the burden that falls in so random a way upon those who become the casualties of activities undertaken for the convenience and utility of society...

Once society as a whole has accepted the need to support certain groups of injured persons, equity requires that all should be included. The essential principle of community responsibility carries with it as a natural corollary the equitable principle of comprehensive entitlement.

As set out above, the reason workers received compensation prior to ACC was not the harm per se, but that the harm arose from the breach of the specific legal duty within a unique legal, economic and political relationship. Compensation was provided to those harmed "through work" in a legal relationship where one party had an obligation to prevent such harm and a long-standing corollary obligation to compensate, and the other party had the economic and political power to cause significant disruption.

This thesis argues that not only is the basis of the claim to workers' compensation different to the claim for social welfare, but that this difference matters when it comes to achieving the goals of this thesis, especially in relation to improving work health and safety. The "why" of compensation in the social welfare tradition has the potential to undermine the rights of workers and the actions needed to ensure work health and safety. For example, the Woodhouse Report framed its reasoning this way: ${ }^{235}$

The toll of personal injury is one of the disastrous incidents of social progress, and the statistically inevitable victims are entitled to receive a co-ordinated response from the nation as a whole.

Workers harmed at work are considered the "inevitable victims" of "social progress." As set out above, Woodhouse considered members of society should "all share in sustaining those who become the random but statistically necessary victims" of "community activities. ${ }^{236}$ Harms are viewed as the inevitable and justifiable costs incurred in the pursuit of economic activities from which we all are said to benefit.

This argument runs contrary to the ends of health and safety identified above. First, such "accidents" are not unavoidable random losses or the inevitable consequences of

\footnotetext{
235 Woodhouse Report, at 1.

${ }^{236}$ Woodhouse Report, at 39.

82
} 
productive activity, rather, adopting a labour law approach, work-related injuries and illnesses are the product of the social and economic conditions of work and the product of conscious decision making about return on money spent on staffing, training, equipment and organisational communication. Second, they are not losses incurred in the creation of profits from which we all equally benefit as society. They are losses worn disproportionately by an individual in a weaker position to the person they are contracted to perform labour for, and who decides on the level of risk they are exposed to. The losses also tend to follow the intersections of culture, ethnicity and gender. Empirically, looking at patterns of wealth distribution, and the patterns of work-related injury and illness, society as a whole benefits far less from such private profit creation than Woodhouse is suggesting. This notion, much like "trickle down" economics has been disproven and abandoned. ${ }^{237}$

Further, the argument of injuries and illnesses being "statistically necessary" to obtain economic benefits also has another negative consequence for health and safety, by suggesting that some level of harm is acceptable and beneficial. This allows for some efficiency and return-on-investment based analysis to slip from private insurance in to social insurance (discussed further below). Effectively, as long as the activity offers a "benefit to society" and, as long as the losses to the individual are underwritten by society as a whole, then it is acceptable to trade off the health, safety and lives of a few workers. This thinking commodifies the worker. In contrast to the claim above that "labour is not a commodity," this thinking logically supports the view that an individual worker is expendable for the greater good of economic value creation. Both the private insurance and social insurance approaches assume that some level of loss is inevitable and optimal.

If, as Woodhouse argues, workers should be entitled to compensation because of the incapacity itself, rather than the circumstances of the harm, it follows then that harmed workers are an unavoidable and inevitable cost to society that must be borne by its

\footnotetext{
${ }^{237}$ See International Monetary Fund report which called for the abandonment of trickle-down theory: Era Dabla-Norris, Kalpana Kochhar, Nujin Suphaphiphat, Frantisek Ricka, Evridiki Tsounta Causes and Consequences of Income Inequality: A Global Perspective (International Monetary Fund, 2015); See also "Trickle-down economics" in John Quiggan Zombie Economics: How Dead Ideas Still Walk Among Us (Princeton University Press, Princeton, 2010).
} 
members. Following the Woodhouse reasoning if everyone agrees to this out of a sense of "common brotherhood" then, logically, society would to seek to minimise these losses. Unfortunately, framing injured workers as a "cost to all" tends instead to be used to affirm victim-blaming political narratives, and an attempt to reduce the costs to society by reducing the cover available. Under this analysis, harm to workers ought to be avoided as it is "a cost to society." However, conceiving of someone primarily as a "cost" to be managed or avoided results in a range of "management options," not all of which promote the health and safety or the dignity and rights of the worker. There are real negative consequences for health and safety to framing worker injuries and illnesses as "accidents, unavoidable like any other" and to framing injured or ill workers as "costs to society" as analysed in greater detail in Chapters Four, Six and Seven.

The problems with this are particularly evident in relation to chronic work-related health conditions. Workers suffering lung cancer as a result of an employer "saving money" on respirators to ensure a better return to shareholders is not an "accident," akin to falling off one's bike. Nurses with depression and anxiety after years of short-staffing to achieve hospital financial targets are not "accidents," like tripping over the dog. The individuals may be, as human beings and citizens, equally deserving of access to treatment, rehabilitation and earnings support, but "as workers harmed through work" they are also entitled to safe and healthy work. As part of this, workers are entitled to a compensation scheme that helps to improve the terms and conditions of work which caused their incapacity, and which does not act to undermine health and safety efforts through the characterisation of the circumstances of their harm as unavoidable, inevitable or from which everyone in society benefits.

As discussed further in Chapters Six and Seven, the norms and narratives created and enforced by ACC impact on health and safety. This impact is especially important as the HSWA is primarily drafted with statements of general principle and not prescriptive rules. ${ }^{238}$ For example, where the primary duty is to take "all reasonably practicable steps"

\footnotetext{
${ }^{238}$ See Neil Gunningham "Lessons from Pike River: Regulation, safety and neoliberalism” (2015) 26(4) NZULR 736. See also Michael Quinlan and Peter Sheldon "The enforcement of minimum labour standards 84
} 
there is considerable scope within what may be considered reasonable. What might be reasonable in an activity characterised as "managing inefficient but unavoidable losses" may fall well short of what is required in "preventing a violation of human rights and dignity." The Independent Taskforce on Work Health and Safety identified a "risk tolerant culture" operating at all levels in New Zealand. ${ }^{239}$ The Taskforce report highlighted the lax attitudes of employers and the regulator as being a significant problem, along with the lack of coordination between ACC and OSH (the predecessor to WorkSafe). ${ }^{240}$ As discussed above, health and safety enforcement priorities and actions reflect the attitudes and norms of the wider environment. That environment in New Zealand is heavily influenced by ACC and its language.

This thesis does not oppose the wider social insurance project started by Woodhouse, and recently advocated by Palmer and Forster, nor does it seek to diminish the importance of welfare provision, or the rights of people with incapacities from other origins. This thesis seeks to develop a model of reform that can achieve the goals of prevention, improving work health and safety as well as providing fairer compensation to workers injured or made ill through work. How this model can achieve this and also operate to support the wider provision of social insurance is discussed in Chapters Seven and Eight.

\section{DWhy reject a torts and insurance-based solution?}

Through the 1990s the "social insurance function" of the ACC scheme was recast as performing a private insurance function, with citizens now becoming shareholders due a return. Accident Compensation: A Fairer Scheme, produced by the then Minister Bill Birch, proposed a number of changes to make ACC more "insurance-like", and to open the

in an era of neo-liberal globalisation: An overview" (2011) 22(2) ELRR 5; and Schindeler and Ransley, above at $\mathrm{n} 224$.

${ }^{239}$ Independent Taskforce, above at $\mathrm{n}$ 32, at 31.

${ }^{240}$ Above, at Part 2 of Report. 
scheme to competition from the private insurance market. ${ }^{241}$ The functions of insurance law are set out by Markin and Steele:242

\begin{abstract}
Insurance... performs a number of different roles, and its influence is not to be reduced to the single contribution often attributed to it, namely, 'loss-spreading'. Insurance is not only a feature of public and social responses to risk, but also a core institution of the market and a key feature of market relationships.
\end{abstract}

There are similarities between the private insurance and social insurance reasoning. In private insurance, losses are spread between policy holders rather than taxpayers. Both focus only on the "incapacity" and allow for the conclusion that harm is not only unavoidable but necessary and, on balance, a net positive.

Within this approach, if the reason to prevent harm is to avoid cost and inefficiency in the apportionment of losses, it must then logically be acceptable to cause harm where it would be more profitable than costly, and thus a more efficient allocation of resources, resulting in a net economic gain. If the possible risks are likely low, and will manifest at some undetermined period in the future, then the correct prevention actions ought to be those that are proportionate to the risk of future costs. ${ }^{243}$ This reasoning is especially problematic when applied to chronic health problems. Where costs are unlikely to manifest in the short term (e.g. chronic health problems with long lead-in times) or there are sufficiently confounding sets of factual variables that they can reasonably be expected to be avoided (e.g. mental health or cardiovascular diseases), then there is little reason to prioritise these losses. Under the private insurance model, and also the social insurance model, "accidents" with immediately manifest losses will always take priority to the "possible losses" that may manifest, and which are easier to avoid liability for.

Loss-spreading is part of the reason employers buy in to any system of workers' compensation. It is argued as a way to insure against shocks (from expensive acute incidents) and manage losses more efficiently. However, this thesis starts with the

\footnotetext{
${ }^{241}$ Birch, above at $\mathrm{n} 47$.

${ }^{242}$ Rob Merkin and Jenny Steele Insurance and the Law of Obligations (Oxford, OUP, 2013) at 3.

${ }^{243}$ See Robinson, and Dorman, above at 214; See also Moore and Viscusi, above at n 217.
} 
assumption that labour is not a commodity and labour markets are not just another market. Workers' injuries are not primarily to be viewed as an economic loss to the business, or a potential cost to be optimally managed, but as a moral wrong, a violation of an individual's rights and an insult to human dignity. As such, approaching the question of ACC reform as one of insurance law is rejected. Brian Langille explains that: ${ }^{244}$

\begin{abstract}
From a pro-market perspective the claim that 'labour is not a commodity' is simply empirically false... the deployment of the idea of 'inequality of bargaining power' is taken as an indicator of economic illiteracy. But, as I have tried to explain elsewhere, claims about 'inequality of bargaining power' or that 'labour is not a commodity' are not empirically false because they are not empirical claims at all. They are normative claims. Talk of 'inequality of bargaining power' is a form of economic nonsense if intended to be a claim within market theory. But it is not intended as a claim within market theory, but is a remark external to, and about, market theory, which makes an important point about the limitations of market theory given its scant normative resources.
\end{abstract}

The research problem in this thesis is not framed as one of how the ACC scheme might better serve businesses or markets, or more efficiently allocate the losses of economic activity, but rather, how it might better serve workers (both in terms of cover and prevention). It is explicitly focussed on the rights and treatment of workers and starts from a normative stance that labour is not a commodity and harms suffered in the course of work should not be viewed as "inevitable" or a "net economic gain".

It could be argued that a return to tort claims would allow for the direct link between business activity and worker harms to be addressed, restoring the recognition of workers' legal rights and allowing for the recognition of the wrongs of poor health and safety. This is unlikely to work in practice, and especially in relation to chronic work-related health problems. A litigation-based model may entrench and reinforce imbalances of power, with employers able to use their greater economic resources to defeat claims and influence the development of the law. As discussed above, one aim for the reforms proposed is to address the imbalance in bargaining power, and a scheme that requires individuals to commence legal proceedings, with the attendant costs, is unlikely to positively impact on that power imbalance. A return to civil litigation, even with compulsory liability insurance, and

${ }^{244}$ Brian Langille, above at $\mathrm{n}$ at $\mathrm{n} 123$, at 105-106. 
resolved primarily in settlements, as in England, would not produce an ideal outcome for either workers' compensation or health and safety in New Zealand. ${ }^{245}$

A litigation-based system would also fail to achieve the goals of improved health and safety, especially when it comes to chronic health problems, which are the focus of this thesis. The argued "compliance incentives" provided by litigation risk do not operate well where workers suffer chronic health problems. Health problems with longer lead in times, where there is a lack of reliable exposure data, or where there are complex interactions of multiple causes or limited scientific understandings of mechanistic cause make litigation less viable as a means of either obtaining compensation or improving health and safety.

In addition to the original access to justice problems identified by Woodhouse in the $1960 \mathrm{~s},{ }^{246}$ mental illness, occupational cancers and mutagenic substance exposures place an unduly complex task on generalist jurisdiction courts. This is not intended as a criticism of the current handling of cases by the District Court, but rather, a policy statement that the courts are not the correct institution to be given the task. As set out in Chapter Seven below, this thesis proposes a specialist panel with a clearly defined set of legislative principles for decisions on the boundaries of cover, either operating within ACC at first instance, or the proposed independent ACC Ombudsman. ${ }^{247}$ While appeals to the generalist jurisdiction courts should, as a matter of justice, always remain open to claimants, the day-to-day work of marginal claims determination would be best handled by independent specialists.

\section{Conclusion}

This chapter has provided a discussion of the theoretical approach taken in the thesis and explained the basis for conceiving of the project as one within labour law, rather than social welfare, tort or insurance. Reflecting the purposive labour law approach, the project starts with explicit aims, to improve the compensation of workers and health and safety, and an

\footnotetext{
${ }^{245}$ Peter McKenzie, above, at n 221.

246 Woodhouse Report.

${ }^{247}$ Forster, Barraclough and Mijatov, above at $\mathrm{n} 9$.
} 
examination of the philosophical basis for these aims, drawing on the literature to understand how the framing of the ends sought impacts on the achievement of them. This approach also informs the method to be used in the thesis. The aims and guiding principles articulated in this chapter inform the analysis of the problems with the current scheme in the next two chapters. 


\title{
CHAPTER FOUR: THE PROBLEMS WITH THE CURRENT ACC COVERAGE
}

\author{
The Consequences of the Centrality of "Accident"
}

\section{Introduction}

The previous chapters have outlined the unique history of the ACC scheme, including its political compromises and theoretical tensions. Drawing the original boundary lines of the scheme around the concept of "accident" created an inherent rationing problem, which has been continued in subsequent iterations of the legislation. Following Davidov's purposive labour law approach, this chapter seeks to understand the problems that have developed in the current ACC scheme, and how the scheme is failing to meet the needs of workers. The operation of the work-related injury and illness cover provisions in the ACA will be examined with the gaps in cover and the negative flow-on effects for health and safety identified. This chapter argues that the lack of a clear basis in principle for determining the boundary lines of cover has resulted in an overly technical approach, focusing on the specifics of the disease in the body and codifying the thinking on specific diagnoses at a given point in time. It will argue that it is the lack of clarity in the "ends sought" which are at the heart of the problems. 


\section{The Current Coverage of Work-Related Health Problems}

The ACA can be thought of as operating a tiered cover system, starting with the definition of accident in section 25. As set out in Chapter One, "accident" is "a specific event or a series of events, other than a gradual process" that involves the: ${ }^{248}$

....application of a force (including gravity), or resistance, external to the human body; or involves the sudden movement of the body to avoid a force (including gravity), or resistance, external to the body; or involves a twisting movement of the body.

The definition of "accident" includes a range of injuries from falling, or being crushed, or cut by machinery. Accident can also include the inhalation or oral ingestion of any solid, liquid, gas, or foreign object "on a specific occasion" but not the inhalation of an infectious substance. ${ }^{249}$ This means that acute incidents of poisoning or choking would be included within "accident", but not the long-term effects of swallowing or inhaling hazardous or infectious substances. Accident includes burns and some incidences of exposure to radiation or extremes of temperature. ${ }^{250}$ The definition of accident focuses on acute physical injury, being an immediate or sudden impact on the body from something external, such as being hit by a car or falling log, being burnt in an explosion or chemical spill, choking or swallowing something poisonous.

Workers with injuries that fall within the definition of accident are not required to establish any causal connection to work to have an entitlement. If a worker's injuries fall outside the scope of section 25, there is a second tier of cover, provided by section 30 and the Occupational Diseases Schedule. Workers are required to meet one of the various tests of causal connection provided in the schedule or section 30. If the worker's health problems fall outside these tests there are two final narrow categories of cover provided in section 21B and 28. The cover tests depend on the type of harm that the worker has suffered, and

\footnotetext{
${ }^{248}$ Section 25(1)(a).

${ }^{249}$ Note: Except where inhalation occurs as a result of criminal activity or if it is work-related and falling within section 30 as discussed below.

${ }^{250}$ Section 25(1)(e).

92
} 
there are multiple tests operating, each in a slightly different way, resulting in significant gaps in cover.

\section{A The Occupational Diseases Schedule}

A worker with an injury that falls outside of "accident" within the meaning of section 25 may be able to obtain cover under the occupational diseases schedule. The schedule provides cover to the "classic" occupational diseases of the $20^{\text {th }}$ century such as lead or arsenic poisoning, silicosis, a limited range of zoonosis diseases (from animals and carcasses) and a limited range of diseases from inhaling toxic substance containing dusts or fumes. The diseases included on the schedule are more a reflection of the diseases that formed major union campaigns in the early $20^{\text {th }}$ century than any distinct classification of medical conditions, or group of conditions with any common characteristic or relationship to work. ${ }^{251}$

The schedule was originally based on the list of occupational diseases set out in ILO Convention 42, the Workmen's Compensation (Occupational Diseases) Convention 1934, which New Zealand was a signatory to, but then failed to ratify subsequent amendments of, and excludes many categories of occupational disease included on the current ILO list. ${ }^{252}$ In 2005 a Ministerial Advisory Panel reported concerns that the Schedule was too restrictive, and based on a 2005 NOHSAC Technical Report ${ }^{253}$ the then Minister for ACC commissioned a further review, led by NOHSAC. The resulting report recommended that the schedule be amended to include "most, if not all the entries on the ILO annex" and

\footnotetext{
${ }^{251}$ See J Leigh “A History of Occupational Disease Recognition and Control” (2007) 23 J Occup Health and Safety Aust NZ 6.

${ }^{252}$ Eun-A Kim and Seong-Kyu Kang "Historical review of the List of Occupational Diseases recommended by the International Labour organization (ILO)" (2013) 25 Annals of Occupational and Environmental Medicine 14.

${ }^{253}$ Tim Driscoll, Andrea 'TMannatje, Evan Dryson, Anne-Marie Feyer, Philippa Gander, Selwyn McCracken, Neil Pearce and Mark Wagstaffe NOHSAC Technical Report: The Burdon of Occupational Disease and Injury in New Zealand (NOHSAC, Wellington, 2004).

93
} 
included a recommended new schedule. ${ }^{254}$ The recommended schedule was not adopted but some new diseases were added in 2008.

Within the schedule each condition tends to have its own test of causation, which can be very specific. For example, "[p]neumoconioses caused by sclerogenetic mineral dust (silicosis, anthraco-silicosis, asbestosis) and silico-tuberculosis, provided that silicosis is an essential factor in causing the resultant incapacity or death." Or "[a]ngiosarcoma of the liver diagnosed as caused by vinyl chloride monomer". ${ }^{255}$ The schedule adopts a very "diagnosis specific" style of drafting, confines cover to very traditional occupational conditions, and offers little scope for expansions in cover, or the ability to reflect shifts in medical thinking. Conditions involving exposure to one of the identified substances are either given a specific test, for example, "[b]ladder carcinoma diagnosed as caused by 2naphthylamine, benzidine, 4-aminobiphenyl, N, N-Bis (2-chloroethyl)-2-naphthylamine, other aromatic amines, or poly-cyclic aromatic hydrocarbons" or framed as "diseases of a type generally accepted by the medical profession as caused by..." and then the given substance. As will be discussed further below, the schedule is inherently backwardlooking, offering cover only to those conditions that have already won their occupational status and excluding newer or less well-researched diseases.

\section{B Section 30 cover of gradual processes, diseases or infections}

The second way that cover is provided for those conditions falling outside "accident" is under section 30. Cover is provided to a person who has suffered a personal injury (other than a mental injury), which is gradual process, disease or infection in the following circumstances: ${ }^{256}$

(a) the person-

\footnotetext{
${ }^{254}$ Tim Driscoll, Evan Dryson, Anne-Marie Feyer, Philippa Gander, Selwyn McCracken, Neil Pearce and Mark Wagstaffe Review of Schedule 2 of the Injury Prevention Rehabilitation and Compensation Act 2001 (IPRC Act) (NOHSAC, Wellington, 2005).

${ }^{255}$ Occupational Diseases Schedule, cl. 1 and 21.

${ }^{256}$ Section 30(1) and (2). 
(i) performs an employment task that has a particular property or characteristic; or

(ii) is employed in an environment that has a particular property or characteristic; and

(b) the particular property or characteristic-

(i) causes, or contributes to the cause of, the personal injury; and

(ii) is not found to any material extent in the non-employment activities or environment of the person; and

(iii) may or may not be present throughout the whole of the person's employment; and

(c) the risk of suffering the personal injury-

(i) is significantly greater for persons who perform the employment task than for persons who do not perform it; or

(ii) is significantly greater for persons who are employed in that type of environment than for persons who are not.

The case law on section 30 indicates the claimant has the burden to prove four elements in order to obtain cover. ${ }^{257}$ First, "there must be proof of a personal injury caused by a gradual process, disease or infection arising out of or in the course of employment" for this element "it is generally necessary to prove a discrete physical injury" and also a "causative link to a gradual process. ${ }^{" 258}$ Second, the claimant must identify that a particular employment task or environment had a particular characteristic that caused their condition. This element is "critical" as it serves as the comparative basis for the next two steps. Third, the claimant must show that the identified property or characteristic is not found to any material extent in their non-work activities. Finally, they must provide evidence that the risk is "significantly greater for persons performing that employment task in that environment, than for persons who do not perform that task in that environment." ${ }^{, 259}$

Section 30 is essentially formulated to cover an "occupational disease," being a disease contracted by a person employed in the type of work where a particular disease has been accepted as significantly more likely to occur, rather than simply a disease that can be factually shown to have been caused by the particular person's work.

\footnotetext{
${ }^{257}$ Christian v Accident Compensation Corporation [2006] NZACC 133 (DC), at [19]. See discussion of the impact of the burden in Wakenshaw $v$ Accident Compensation Corporation [2003] NZHC 1005.

${ }^{258}$ Wakenshaw $v$ Accident Compensation Corporation, above.

${ }^{259}$ Wakenshaw, as above. See also Knox v Accident Rehabilitation and Compensation Insurance Corporation [2000] NZHC 1215, per Young J.

95
} 


\section{The concept of occupational disease}

The concept of an "occupational disease" is a fundamental, but politically complex one. As a matter of fact there is no way to distinguish between occupational and nonoccupational diseases in blood tests or under a microscope. Occupational diseases are given that label either because the medical profession has accepted there is a strong statistical relationship between the rates of disease suffered by those in a given industry compared with the general population, or because of the political and historical context of the condition. ${ }^{260}$ "Occupational disease" is a contested and political label. The leading textbook in occupational medicine explains this, stating: ${ }^{261}$

There is a widely held belief...that diseases of occupational or environmental origin are both rare and distinctive. In reality, diseases caused by work and ambient environment are neither rare nor often distinctive in their clinical presentation and laboratory findings. Most occupational diseases, such as occupational cancers, not only resemble diseases caused by other factors but are otherwise indistinguishable except by careful documentation of history of a relevant exposure. Other occupational and environmental diseases, like asthma or dermatitis, may be distinguished clinically only through obtaining an exposure history, with or without specialised testing, which presupposes high suspicion for the diagnosis.

The factual complexity and state of medical thinking on many of the diseases cover is sought for make the combined operation of the Schedule and section 30 particularly difficult. In Christian v ACC and Nelson Pine Industries Ltd ${ }^{262}$ the case turned on the correct diagnosis of the claimant's lung disease as he had been given two diagnoses, chronic obstructive pulmonary disease, which is covered by the schedule, and bronchiesctasis, which is not. However, the precise nature of either of the diseases he was diagnosed with, the difference between them, and whether it was possible to have both, was unknown and unable to be clarified by medical evidence. The problem with a schedule

\footnotetext{
${ }^{260}$ See recent discussion of definition in Lesley Rushton "The global burden of occupational diseases" (2017) 4 Curr Envir Health Rpt 340. See also the World Health Organisation (WHO) discussion on "occupational diseases" (Feb 2017).

$<$ https://www.who.int/occupational_health/activities/occupational_work_diseases/en/>

${ }^{261}$ Mark Cullen, Linda Rosenstock and Edwin Kilbourne "Introduction to Occupational and Environmental Medicine" in Linda Rosenstock, Mark Cullen, Carl Brodkin and Carrie Redlich Textbook of Clinical Occupational and Environmental Medicine ( $2^{\text {nd }}$ ed) (Elsevier Saunders, Philadelphia, 2005) at 3. ${ }^{262}$ Above. 
of covered diseases is that it effectively codifies medical understandings at a particular time. Medical opinions as to the "causes" of certain diseases change over time, and old disease diagnoses get replaced or varied. The schedule approach operates to legislate the "causes" of certain diseases.

The fundamental problem, discussed further in Chapter Six below, is that doctors and lawyers think about causation in very different ways. Medicine can wear a level of uncertainty in the nature of causation that law based on precedent and defined in statute cannot. ${ }^{263}$ Medical research is conducted for very different purposes than establishing legal liability and the translation of medical research into legislation can result in many practical problems, especially in new, complex or shifting areas of medicine. Judge Cadenhead identified that: ${ }^{264}$

the mere fact that there is no research in the particular employment tasks or in respect to the other group for comparison should not prohibit the claim. If that was the case, then no person, who was not in a classified group that had been the subject of research into particular employment tasks under consideration could claim.

However, in many cases, this is exactly the result, even where these is an apparent Schedule disease. The translation of research is particularly difficult if the person's condition arises from new or rare occupational exposures that have not resulted in a sufficient body of evidence to be considered "generally accepted by the medical profession as caused by" the particular agent. For example, in Purdie v Accident Compensation Corporation ${ }^{265}$ the claimant sought cover for sceleroderma (an extremely rare skin condition) she argued was caused by exposure to the solvents xylene and toluene (derivatives of benzene). Diseases arising from exposure to toxic derivatives of benzene and its homologues are included in the schedule. ${ }^{266}$ Given the low incidence of the disease (19 per million in population) there were only a few studies, and although a statistically significant association was found, the studies were not repeated, meaning there was only "weak evidence" and "not yet generally

\footnotetext{
${ }^{263}$ Harvey Teff Causing Psychiatric and Emotional Harm: Reshaping the Boundaries of Legal Liability (Hart Publishing, Oregon, 2009), at 13.

${ }^{264}$ Christian v ACC, above at 257, at [22].

265 [2010] NZACC 13 (DC).

${ }^{266}$ Occupational Diseases Schedule, cl 12.

97
} 
accepted by the medical profession" although no alternative causes could be suggested for the claimant's rare disease. ${ }^{267}$

The current drafting of these cover provisions reflects a wider political debate over the concept of occupational disease, which has been going for over two centuries. ${ }^{268}$ This is because the term effectively operates as the boundary line of employer liability for the consequences of work. From the early 1800s three competing terms emerged, "occupational disease," "work-related disease" and "workers' diseases." The World Health Organisation (WHO) describes the continuing distinction: ${ }^{269}$

An "occupational disease" is any disease contracted primarily as a result of an exposure to risk factors arising from work activity. "Work-related diseases" have multiple causes, where factors in the work environment may play a role, together with other risk factors, in the development of such diseases.

The difference between "occupational disease" and "work-related disease" is one of the "exclusiveness" of work as a cause. In reality, the factual line between "occupational disease" and "work-related disease" is increasingly impossible to draw. The line is political and legal, rather than a factual or medical.

\section{Particular Exclusions}

\section{A A particular problem for female-dominated occupations}

The exclusion of newer or less-researched work exposures has a particular impact on female-dominated occupations. Establishing an "occupational disease" can be difficult for any worker but is especially difficult for workers in female-dominated occupations. There is significantly less research into women's occupational health, meaning that women will

\footnotetext{
${ }^{267}$ Purdie v Accident Compensation Corporation, above at $\mathrm{n} 265$, at [45]-[54].

${ }^{268}$ See Leigh, above at $\mathrm{n} 251$; See also Paul Weindling The Social History of Occupational Health (Croon Helm, London, 1985).

${ }^{269}$ WHO (Feb 2017) <http://www.who.int/occupational_health/activities/occupational_work_diseases/en/> 98
} 
often struggle to establish the occupational status of their disease. ${ }^{270}$ The occupational health of women has been an area of wider neglect internationally, with occupational disease studies often limited to male participants. ${ }^{271}$ A paper prepared for the Global Commission on Women's Health highlighted the particular problems of data collection and presentation when it comes to women's occupational health, with health problems failing to be captured or obscured by the aggregation methods. ${ }^{272}$ Although there have been improvements in recent years, the lack of research coupled with the drafting in section 30 create major hurdles for women in obtaining cover. NOHSAC issued Technical Report 13, Women's Occupational Health and Safety in New Zealand, concluding: ${ }^{273}$

Very little is known about women's OHS. The lack of research in exposures and health effects associated with women's jobs have enforced the widespread assumption that women's jobs are safe, thus perpetuating the lack of knowledge and action on women's occupational ill health.

Much of the work typically performed in female-dominated occupations involves tasks that are not unique to paid work, such as caregiving. Even if there was not a blanket exclusion for stress-related conditions under section 30 (discussed below), the fact that workers may also be performing the same mental and emotional tasks outside of work makes establishing the "exclusiveness" of a work-related cause effectively impossible. Section 30(2)(b)(ii) of the ACA requires that the "particular property or characteristic of the work" alleged to have caused the illness "not [be] found to any material extent in the nonemployment activities or environment of the person." It would be difficult for a person working in a caring profession to be able to show they were "caring" solely in a work

\footnotetext{
${ }^{270}$ See Lado Ruzicka "Issues in Occupational Mortality of Women" and Karen Messing and Jeanne Megar Stellman "Understanding Occupational Disease in Women Workers" in Penny Kane (ed) Women and Occupational Health (WHO, 1997). See also Karen Messing and Jeanne Mager “Sex, gender and women's occupational health: The importance of considering mechanism" (2006) 101(2) Environmental Research 149.

${ }^{271}$ I Niedhammer, M Saurel-Cubizolles, M Piciotti and S Bonenfant S "How is sex considered in recent epidemiological publications on occupational risks?” (2000) 57(8) Occupational and Environmental Medicine 521.

272 Kane, above at n 270.

${ }^{273}$ Andrea ‘T mannetje, Tania Slater, David Mclean, Amanda Eng, Celia Briar, Jeroen Douwes NOSHAC Technical Report 13: Women's Occupational Health and Safety in New Zealand (NOHSAC, Wellington, 2009), at iv.
} 
context. Likewise, where the job involves working with people, and health conditions suffered are common in the wider population (such as a nurse or teacher contracting an infectious disease), workers will struggle to prove the occupational status of their condition, even if they can prove it was, in fact, caused by work.

\section{B Work-related heart attack or stroke}

If a worker's health conditions do not fall within the schedule or are excluded under section 30 , the last tier of available cover is provided by section $21 \mathrm{~B}$ which provides cover to a narrow category of single incident psychological trauma and section 28 which covers heart attack and stroke caused by abnormal physical exertion. Stress-related heart attacks and strokes are excluded from cover under section 30(5)(a), which expressly excludes any work-related health conditions caused by "non-physical stress." The exclusion of these stress-related conditions from ACC has been confirmed in MacFarlane $v$ Accident Compensation Corporation ${ }^{274}$ in 2014 and further in 2016, in Carter v Accident Compensation Corporation. ${ }^{275}$

Section 28(3) provides cover for "a cardiovascular or cerebrovascular episode" (a heart attack or stroke) suffered by a worker if "the episode is caused by physical effort or physical strain, in performing his or her employment that is abnormal in application or excessive in intensity for the person. ${ }^{276}$ Essentially, cover is only available where the heart attack or stroke is "caused by" some unusual physical exertion on the part of a worker in performing an unusually physical task in their ordinarily sedentary work. For example, a solicitor who normally performs desk-based tasks carries heavy moving boxes of textbooks up ten flights of stairs, and it is the physical strain of the act itself that can be considered the cause of the heart attack.

274 [2014] NZACC 141.

275 [2016] NZHC 1140.

${ }^{276}$ Section 28(3). 
For example, in Estate of Wei $v$ Accident Compensation Corporation ${ }^{277}$ Wei died of a heart attack after being assaulted by a group of youths while working in his electronics shop. Although the judge considered the "physical effort in the struggle during the assault" may meet the requirements, this could not be said to have "caused" the cardiovascular episode, meaning Wei's estate could not obtain compensation. The medical evidence revealed underlying asymptomatic heart disease. The Court recognised that the additional physiological stress may have triggered the heart attack but this did not amount to cause. It also acknowledged that had the assault not occurred the heart attack may have been prevented with medical intervention. Although stress was a factor here, the Judge held that "physiological stress" did not meet the definition of "physical stress."

What this case highlights is the change in medical thinking that has occurred since the original inclusion of the cover provisions. Heart attacks were, in the early part of the 20th century, considered by policy makers to be caused by physical exertion, essentially, the heart gave out through overwork. Just like a muscle could tear from too much force being exerted, so to, a heart was thought to be injured by excessive force, and so it was thought of as an "accident". Nowadays, heart attacks are viewed as acute events caused by a blockage in blood vessels to the heart in cases of cardiovascular disease. It would be extremely unlikely for a worker to have a heart attack in the circumstances set out in section 28(3) without pre-existing heart disease or a pre-existing structural defect, meaning the section, as drafted, offers little assistance to workers in the contemporary workplace. As in the case of $W e i$, the physical exertion would at best, be considered to operate as a trigger to an inevitable event, and would not likely, on review of the medical evidence, be considered "the cause." Work-stress-related cardiovascular disease is a significant cause of death and disability in the New Zealand workforce that will be discussed in greater detail in Chapter Five.

277 [2004] NZACC 338. 


\section{Mental health problems}

As with heart attack and stroke, section 30(5)(a) excludes the majority of work-stressrelated mental illnesses. "Mental injury" is defined in the ACA as "a clinically significant behavioural, cognitive, or psychological dysfunction. ${ }^{278}$ Cover is limited to mental injuries that arise "because of a physical injury"279 for example, alien limb syndrome following amputation and those caused by certain criminal acts. ${ }^{280}$ Section $21 \mathrm{~B}$, inserted in 2008 , extended cover to work-related mental harm resulting from very narrowly defined single incident trauma and was inserted following lobbying by transport unions, high-profile legal cases and increased media attention.

Although an expansion in cover, section 21B continues to exclude all but a very narrow range of cases. To obtain cover under section $21 \mathrm{~B}$ a person is required to experience the event directly and the event is required to be "an event that could reasonably be expected to cause mental injury to people generally." 281 A person "experiences, sees, or hears an event directly" if they are involved in, or witnesses the event, and are "in close physical proximity to the event at the time it occurs." 282 The event is generally required to be a single identifiable event. For example, in the case of $K B v A C C^{283}$ a claim was made by a police officer attending a particularly distressing suicide and having to counsel the family which she alleged caused her condition. The Court declined cover, finding that "the appellant has experienced a significant number of events in the course of her work" and an event meeting the requirements of section $21 \mathrm{~B}$ "must be one that is in effect a one-off event, and which results in the more or less immediate onset of the factors involved in the medical condition of Post-Traumatic Stress Disorder"(PTSD). ${ }^{284}$

\footnotetext{
${ }^{278}$ Section 27.

${ }^{279}$ Section 26(1)(c).

${ }^{280}$ Schedule 3 lists the covered sexual offences.

${ }^{281}$ Section $21 \mathrm{~B}(2)(\mathrm{b})$.

${ }^{282}$ Section $\mathrm{s} 21 \mathrm{~B}(6)(\mathrm{a})-(\mathrm{d})$.

283 [2013] NZACC 41.

${ }^{284}$ Above, at [25].
} 
In OCS Ltd $v T W^{285}$ a claim was made for a mental health problem resulting from a pattern of bullying and harassment which culminated in an incident of minor assault. The Court declined cover, deciding that "minor incidents" were outside the mischief that section 21B was introduced to remedy and the incident complained of had to be "sudden." However, it is worth noting that in the 2016 case of MC v Accident Compensation Corporation, ${ }^{286}$ the claimant suffered a series of traumatic events in the course of employment as a police officer and in active combat in Afghanistan. The Judge in this case took a wider view of the single incident requirements and it remains to be seen what, if any, impact this case may have on the interpretation of the section. However, even if the decision in $M C$ does widen the approach taken to interpretation, it can only stretch the meaning of the words so far. Section $21 \mathrm{~B}$ is clearly drafted to be a narrow category of cover, leaving the vast majority of work-related mental illnesses outside the scope of ACC. Looking internationally, the largest numbers of work-related mental illness claims are for workstress-related illnesses and bullying. ${ }^{287}$ ACC offers little value to the potentially large and growing number of workers affected by these conditions, as discussed further below and in the next chapter.

\section{An outdated mind/body dualism}

Drawing a line between mental health conditions and physical health conditions also creates a set of significant practical problems. Advances in medical science have seen the abandonment of a strict separation between mental and physical illnesses. ${ }^{288}$ The Diagnostic and Statistical Manual of Mental Disorders, the bible of diagnostic criteria for psychologists, concludes that the "term mental disorder unfortunately implies a distinction between 'mental' and 'physical' disorders that is a reductionist anachronism of mind/body

\footnotetext{
285 [2013] NZACC 177.

286 [2016] NZACC 264.

${ }^{287}$ SafeWork Australia Work-Related Mental Disorders Profile 2015 (SafeWork Australia, Canberra, 2016); SafeWork Australia “International Women's Day: Reflecting on women's health and safety in the workplace." (2016) <http://www.safeworkaustralia.gov.au/sites/swa/news/pages/tn09072016>

${ }^{288}$ See discussion on the use of the term "mental" in medicine in R E Kendell "The distinction between mental and physical illness" (2001) 178 BJP 490 at 490.
} 
dualism," retained in the title only "because we have not found an appropriate substitute." ${ }^{289}$ A review of the growing literature into illnesses such as depression (set out in the next chapter) reveals complex disease processes that defy a strict mind or body categorisation. $^{290}$

Maintaining a legislative line between mind and body has also resulted in the judiciary being handed the task of declaring which medical conditions are "mental" or "physical" in the absence of medical consensus or acceptance of such a distinction. ${ }^{291}$ The factual difficulty distinguishing between mind and body is highlighted in the ACC cases of workers suffering with chronic pain conditions, as in Teen $v$ Accident Compensation Corporation and Telecom Ltd ${ }^{292}$ and Meikle v Accident Compensation Corporation. ${ }^{293}$ For example, consider the position of two employees performing a data-entry job involving long hours of typing. Employee A develops carpel tunnel syndrome in the right wrist and employee B develops a complex regional pain syndrome in the right wrist. Both employees experience physical pain associated with the nerves in that wrist. Employee A's condition is caused by pressure on the nerves. Employee B's condition is thought to be caused by a psychological interaction with the nervous system that causes the involuntary misfiring of pain signals to the nerves, rather than specific tissue damage (although it may be triggered by specific tissue damage). Although there is a recognised psychological component to employee A's condition, it is considered physical, and although there is a recognised physical component to employee B's condition, it is considered psychological by ACC,

\footnotetext{
${ }^{289}$ American Psychological Association Diagnostic and Statistical Manual of Mental Disorders $\left(4^{\text {th }}\right.$ ed, American Psychological Association, Washington DC, 1994) at Introduction 1.

${ }^{290}$ See Brian Shenal, David Harrison and Heath Demaree "The Neuropsychology of Depression: A Literature Review and Preliminary Model" (2003) 13(1) Neuropsychology Review 33; and Dominique Musselman, Dwight Evans and Charles Nemeroff "The Relationship of Depression to Cardiovascular Disease: Epidemiology, Biology and Treatment” (1998) 55(7) Arch Gen Psychiatry 580.

${ }^{291}$ See discussion in ETN v Accident Compensation Corporation [1998] NZACC 227, Gable v Accident Compensation Corporation [2003] NZACC 212, Teen v Accident Compensation Corporation and Telecom Ltd [2002] NZACC 244 and Meikle v Accident Compensation Corporation [2008] NZACC 158.

292 [2002] NZACC 244.

${ }^{293}$ [2008] NZACC 158.
} 
and thus excluded from cover. ${ }^{294}$ Leaving aside any question of whether it is fair to treat employee A and B differently, the distinction between their conditions is, as a matter of fact, very difficult to draw

The problem of worker mental illness in New Zealand is receiving greater attention by local and international organisations, but is not new. ${ }^{295}$ Work-related mental health problems were included in the terms of reference for the 1990 National Government ACC Working Party. ${ }^{296}$ In Bill Birch's 1991 ACC reform document, he stated: “[s]tress claims are a major cause of escalating costs in those overseas workers' compensation schemes that compensate for stress." ${ }^{297}$ The grounds provided for continuing to exclude claims in New Zealand were "not only the high cost, but also that stress is a result of a number of interrelated factors." 298 This decision reflected the wider political agenda of reducing government spending, but also a fear of opening the floodgates that the more complex causality issues surrounding mental illness generate. This fear has been echoed many times since and will be discussed further in the Chapters Five and Six.

\section{E Work-related infections}

A final category worth mentioning in an analysis of the gaps in cover are work-related infections. Work-related infections arising from a physical injury within the definition of accident are generally covered by ACC. For example, work-related ecto-parasitic infection (e.g. scabies) or contraction of a disease "by an arthropod as vector" (e.g. malaria contracted via infected mosquito) are covered. ${ }^{299}$ The focus is on a specific injury, the "bite," by the insect as the injury that gave rise to the infection. In this way, it is analogous

\footnotetext{
${ }^{294}$ See cases of Teen, and Meikle, above at n 291; For discussion of these disorders see Richard Mayou, Laurence Kirmayer, Greg Simon, Kurt Kroenke and Michael Sharpe "Somatoform Disorders: Time for a New Approach in DSM-V" (2005) 162 Am J Psychiatry 847.

${ }^{295}$ OECD, above at n 10; Government Inquiry in to Mental Health and Addiction He Ara Oranga: Report of the Government Inquiry in to Mental Health and Addiction (NZ Government, Wellington, 2018).

${ }^{296}$ Birch, above at n 47, at Minister's Forward.

${ }^{297}$ Above, at 32.

${ }^{298}$ Above.

${ }^{299}$ Section 25(2)(c).
} 
to a needle stick injury, where disease is contracted through the puncture wound. It is the "accident" of being bitten or stabbed that gives rise to the injury and which makes the condition compensable, rather than the work-related infection per se. The scheme covers some other work-related infections through the Occupational Diseases Schedule and section 30 , but the coverage is patchy, outdated and inconsistent, lacking in any discernible basis in principle for who receives cover. This can be seen in the patchy coverage of diseases contracted by working with animals.

Some specific diseases "diagnosed as caused by working with animals or their carcasses" 300 are covered in the Schedule (anthrax, leptospirosis, brucellosis, orf and streptococcus sui) but many others are not, and despite the similarity with the Schedule diseases, fail to fall within the test in section 30. For example, in Aldridge $v$ Accident Compensation Corporation, ${ }^{301}$ a dispute arose over whether the claimant's lung disease was caused by inhaling deer dander. Deer related diseases are not included in the Schedule and although deer farming had been associated with increased risks of lung diseases, the particular lung disease the claimant suffered from was not established in a significantly greater number in deer farmers than other farmers.

The ACC provisions also do not cover many chicken-related diseases, excluding processing workers that contract campylobacter in either its acute form or the subsequent inflammatory or rheumatoid effects of recurrent exposures. ${ }^{302}$ In relation to pigs,

\footnotetext{
${ }^{300}$ Schedule cl. 17-20.

301 [2007] NZACC 154.

${ }^{302}$ See Petra Mueller, Nikki Kells and Donald Campbell Ministry of Primary Industries Risk Profile: The emergence of campylobacter jejuni ST 6964 in poultry in New Zealand and its associated antimicrobial resistance Technical Paper No 2016/16 (Ministry of Primary Industries, Wellington, 2016) for a discussion of risks in New Zealand. See also G Klous, A Huss, DJJ Heederik and RA Coutinho "Human-livestock contacts and their relationship to transmission of zoonotic pathogens, a systematic review of literature" (2016) 2 One Health 65; J Leibler, J Otte and E Silbergeld "Zoonotic disease risks and socioeconomic structure of industrial poultry production: review of the US experience with contract growing" (2008) Agriculture 1 for wider discussion of risks of infectious diseases for poultry workers. See also, campylobacter risks in dairy farms in New Zealand discussed in B J Gilpin, P Scholes, and B Robson "The transmission of thermotolerant Campylobacter spp. to people living or working on dairy farms in New Zealand" (2008) 55 Zoonoses Public Health 352.
} 
streptococcus suis is covered, ${ }^{303}$ but where a similar disease could spread to the public, and is not by definition "occupational," and leaves infected workers without cover. For example, if pig workers contract diseases such as swine $\mathrm{MRSA}^{304}$ that can subsequently enter the wider human population, they would be excluded, despite their higher risk and the fact they contracted the disease at work, working with pigs. There seems, as a matter of legal or policy principle, little basis on which to distinguish between the diseases of sheep or deer, exclude almost all diseases contracted through handling chickens, or the newer or mutated variants of swine diseases. These provisions can only be understood as a product of the political history of these diseases. The apparent preference given to sheep workers is likely the result of campaigns by the Australian and New Zealand Shearers' Unions in the 1920 s to 1940 s for recognition of certain diseases in the Workers' Compensation Act 1956.

Coverage is even worse for workers exposed to infectious diseases while working with humans, such as health care workers and teachers. Despite the higher risks of infection that arise from the nature of their work, the diseases contracted are not "occupational" as being infectious, the diseases can be found in people working outside their working environment. A nurse that contracts Ebola, or a teacher working in a school with an outbreak of measles would not receive cover for the disease or any subsequent incapacitating complications. Sick leave provision under the Holidays Act 2003 provides for five days sick leave per year, and while unions in these fields have managed to negotiate improved sick leave policies, there is a big difference between "discretionary" sick leave and ACC cover, which also includes treatment costs, rehabilitation and other support.

\footnotetext{
${ }^{303}$ See Guillaume Goyette-Desjardins, Jean-Philippe Auger, Jianguo Xu, Mariela Segura and Marcelo Gottschalk "Streptococcus suis, an important pig pathogen and emerging zoonotic agent - an update on the worldwide distribution based on serotyping and sequence typing" (2014) 3(6) Emerg Microbes Infect e45.

${ }^{304}$ B Springer, U Orendi, P Much, G Hoger, W Ruppitsch, K Krziwanek, S Metz-Gercek and H Mittermayer "Methicillin-resistant Staphylococcus aureus: a new zoonotic agent?" (2009) Wien Klin Wochenscher 121; and M Wulf and A Voss "MRSA in livestock animals-an epidemic waiting to happen?" (2008) 14 Clin Microbiol Infect 6.
} 


\section{F Gaps as a consequence of the focus on "accident"}

The ACC scheme revolves around the problematic concept of "accident" and the current gaps in cover can be seen as the logical consequence of this. As discussed in Chapter Two, limiting the scheme to "accident" and a few pre-existing categories of "occupational disease" was a political decision, intended only to be temporary, but which remained, with cover further nibbled away in the decades that followed. "Accidents", as defined in section 25 , are not a particularly distinct or morally deserving category of harms. Without a central hinge in principle (such as played by the concept of work in workers' compensation schemes discussed above) to answer questions of cover, the scheme begins to focus on the specifics of diagnosis, drawing arbitrary lines around particular parts of the body or particular diseases. As a result, when new conditions emerge or the medical science changes, the legislative lines must be redrawn. Sir Geoffrey Palmer, writing in 1977, observed that "the cut and fill approach to legislative reform has now become so ingrained with the accident compensation legislation that the pattern will be difficult to alter." ${ }^{305}$ In his view, there was "a danger in any busy organization of more than four hundred people that efforts to generate policy will concentrate on putting out individual fires without pausing to contemplate the nature of the forest in which the fires burn." ${ }^{306}$ The current provisions are perhaps the fulfilment of those predictions.

For example, what is the difference, as a matter of principle, between catching a disease from handling sheep carcasses and catching a disease from handling chicken carcasses? Yet the eligibility test for cover is different. Why should contracting a disease at work "via an arthropod as vector" (for example, a mosquito carrying infected blood) be treated differently to contracting the same disease via infected bodily fluids directly? Why should it be easier to obtain compensation for lung cancer caused by asbestos exposure than laryngeal or ovarian cancer caused by asbestos exposure? Why should an ambulance officer who develops PTSD after witnessing a single traumatic event be entitled to cover, when an ambulance officer who develops depression after witnessing 500 such events over

\footnotetext{
${ }^{305}$ Palmer, above at $\mathrm{n} 107$, at 8 .

${ }^{306}$ Above, at 4 .
} 
the course of a career is not? Why is the heart attack of an office worker engaged in unusual physical exertion covered, when a heart attack as a result of years of mental stress at work is not? These inconsistencies are the logical consequences of a lack of principle by which to determine whether something ought to receive cover and as a consequence large numbers of New Zealand workers are being left without support for their work-related health problems.

\section{The Consequences of the Gaps in Cover}

The gaps in ACC cover have a detrimental effect of the New Zealand workforce, leaving individuals without treatment, rehabilitation or income support when harmed through work. Further, the ACC scheme plays a central role in work health and safety in New Zealand, including data collection and improving performance. The gaps in ACC cover have significant flow-on effects for New Zealand's health and safety.

\section{A Options for workers with excluded conditions}

If an employee suffers from an excluded condition caused by their employment, they can sue their employer to obtain compensation. The claim for compensation usually takes the form of a personal grievance for unjustifiable disadvantage under 103(1)(b) of the Employment Relations Act 2000 (ERA), (the disadvantage being the employer's failure to meet their health and safety obligations to the employee), breach of an implied term of the employment contract, or less often, a tort claim for breach of statutory duty or negligence. These actions require the employee to prove the employer's fault in failing to provide healthy or safe work, which the New Zealand Court of Appeal has described as posing "formidable obstacles." ${ }^{" 307}$ For many chronic health conditions, especially those with long lead-in times, the costs and lack of workplace monitoring data make it nearly impossible to prove the required relationship of causation between employment and resulting illness.

${ }^{307}$ Attorney-General v Gilbert, above at n 19, at [87]. 
Time limitations on bringing claims (90 days for personal grievances) also limit the potential of such claims for many illnesses, which may not emerge until years after, or where the breaching conduct is cumulative and an incident or action cannot be identified within the 90 days preceding.

If successful, an employee's personal grievance remedies are usually limited to the remedies of reimbursement of lost wages (generally capped at 12 weeks' ordinary time ${ }^{308}$ ) and compensation for "humiliation, loss of dignity, and injury to the feelings." 309 Personal grievance compensation however is intended to be an award for the intangible harms of the employer's unjustifiable conduct, not to provide for treatment, on-going income support for incapacity, or rehabilitation. The sums awarded in these employment cases (including the contract and tort claims) are rarely generous and often not equivalent to the compensation available under ACC for a physical accident. If a worker is not an employee, then their options are limited to claims of negligence, breach of contract (if the contract provides for health and safety), or breach of statutory duty. There are very few of these cases taken in the New Zealand courts.

The leading New Zealand case in this area is Attorney-General v Gilbert. ${ }^{310}$ The employee, Mr Gilbert, had been employed as a probation officer at the Department of Corrections for over 20 years. He retired on medical grounds with a heart condition and depression caused by excessive stress suffered at work. The court found his health conditions were caused by work overload and management failure, "not just from stress necessarily inherent in his work, but from avoidable additional pressure of workload, office dysfunction, and inadequate resources." ${ }^{111}$ The Court of Appeal considered that the employer was aware of the risks and could foresee the potential impact on Mr Gilbert's health. The Court of Appeal concluded that the employer owed Mr Gilbert a contractual duty to comply with the health and safety legislation as well as the terms of the contract providing him with a safe working

\footnotetext{
$\overline{{ }^{308} \text { Lost wages claims can be extended under section 128(3) but the courts have typically been conservative }}$ in their use of this provision.

${ }^{309}$ ERA, s 123(1)(c)(i).

${ }^{310}$ Attorney-General v Gilbert, above at $\mathrm{n} 19$.

${ }^{311}$ Above, at [8].
} 
environment. ${ }^{312}$ It also concluded that this amounted to a personal grievance. This case has been relied on in a number of other personal grievance cases relating to workplace stress, where employees have argued their health problems resulted from the employer's failure to provide them with safe and healthy work. ${ }^{313}$

In the absence of a successful compensation claim a worker suffering from an excluded work-related health condition has only private insurance (if they have it) and the benefit system to fall back on. In 2013 research was conducted in to the socioeconomic impact of the difference in financial support (ACC versus the support provided through WINZ) on a group of people of a similar age and level of functional impairment. ${ }^{314}$ The study concluded that those in the illness group (not covered by ACC) had "considerably poorer socioeconomic outcomes," did not return to work as early, and were the "most vulnerable for decline into poverty and ill health." 315

The exclusion of these workers from ACC cover also has an impact on employers, with lack of cover directly impacting the cost and management of sick leave, employee absence, rehabilitation and return-to-work planning. Employers are also exposed to civil liability for an employee's work-related mental harm in a way they are not with accidental physical harm. For example, the exclusion of most work-related mental health problems impacts on employers operating businesses in industries where the work performed has a greater mental hazard profile than physical. There was minimal enforcement activity under the former HSEA for mentally unsafe work practices ${ }^{316}$ and the position of the Ministry of Business, Innovation and Employment continues to be to encourage employees to address

\footnotetext{
312 Above.

${ }^{313}$ See Crutchley v Chief Executive of Ministry of Social Development [2008] NZERA 196; Clear v Waikato District Health Board [2007] NZERA 33 and Rosenberg v Air New Zealand Ltd [2009] NZERA 556.

${ }^{314} \mathrm{~S}$ McAllister and others, above at $\mathrm{n} 21$.

${ }^{315}$ Above, at 96.

316 The only prosecution action taken is that of Department of Labour v Nalder \& Biddle (Nelson) Ltd [2005] NZHSE 20.
} 
mental harm issues through mediated settlement. ${ }^{317}$ The absence of standards and enforcement activity in this area ${ }^{318}$ has resulted in little guidance for employers on what amounts to "all reasonably practicable steps" in relation to employee mental health, meaning that it is both more difficult to prevent and defend against employee personal grievance claims if they are brought.

\section{B Lack of data}

In New Zealand work-related health statistics come almost exclusively from ACC administrative data. This means that where there is no ACC cover, there is no data. It is difficult to know the exact impact of the current difference in compensation treatment on excluded work-related health problems because there is no information available on the nature, frequency and type of such harms. WorkSafe estimates that chronic health problems result in an additional 600-900 deaths, ${ }^{319}$ and affect tens of thousands more workers each year. ${ }^{320}$ The Report of the Independent Taskforce highlighted the lack of available occupational health information, stating: ${ }^{321}$

The Taskforce is left with a profound unease about the quality of data in New Zealand. We are deeply concerned that we do not have a clear, reliable picture of New Zealand's performance.

For work-related mental health problems the statistical picture is particularly foggy. The exclusion of mental health problems from ACC, coupled with the emphasis on mediated settlement in the employment jurisdiction, has rendered the problem largely invisible, preventing research, enforcement activity or policy development in this area. In 2009 the Department of Labour commissioned a study Understanding Stress and Bullying in New

\footnotetext{
${ }^{317}$ See Department of Labour Guideline Healthy Work: Managing Stress and Fatigue in the Workplace (June 2003); For most recent statement see WorkSafe New Zealand, above at n 171.

318 Department of Labour v Nalder \& Biddle, above at n 317.

${ }^{319}$ Latest estimate on the Worksafe New Zealand website <www.worksafe.govt.nz>

${ }^{320}$ Although there are no reliable figures on this, in WorkSafe New Zealand, above at $\mathrm{n} 29$, the number was estimated to be over 30,000 people per year.

${ }^{321}$ Independent Taskforce, above at n 32, at 32.
}

112 
Zealand Workplaces, ${ }^{322}$ which provided a snapshot of the extent to which stress and bullying were a problem in given industries. The survey and interview results indicated "the prevalence was relatively high compared to international findings." 323 There are also smaller, industry specific surveys conducted in New Zealand such as the Tertiary Education Union's State of the Sector surveys, ${ }^{324}$ the Public Service Association survey, Workplace Dynamics in the New Zealand Public Services, ${ }^{325}$ and the New Zealand Nurses Organisation employment surveys. ${ }^{326}$

The limited New Zealand research available reflects wider international trends. Australian research concludes that "mental illness is now the leading cause of sickness absence and long-term work incapacity in most developed countries," 327 costing Australian businesses between \$11-12 billion each year in absenteeism, reduced work performance, increased turnover rates and compensation claims. ${ }^{328}$ The 2018 OECD Report, Mental Health and Work New Zealand, concluded: ${ }^{329}$

Given that the cost of serious mental health conditions is higher in New Zealand than in Australia, it can be concluded that the total cost of mental health to the New Zealand society is in the order of around $4-5 \%$ of GDP and thus at the top-end among OECD countries.

\footnotetext{
322 Tim Bentley, Bevan Catley, Helena Cooper-Thomas, Dianne Gardner, Michael O’Driscoll and Linda Trenberth Understanding Stress and Bullying in New Zealand Workplaces: Final Report to the OH\&S Steering Committee (December 2009).

323 Above, at i.

${ }^{324}$ Tim Bentley, Laurie McLeod and Stephen Teo The state of the tertiary education sector in New Zealand - 2013 (TEU, Wellington. 2013); and Charles Sedgwick and Sarah Proctor-Thomson The state of the public tertiary education sector survey 2018 (TEU, Wellington, 2019).

${ }^{325}$ Geoff Plimmer, Jessie Wilson, Jane Bryson, Stephen Blumenfeld, Noelle Donnelly and Bill Ryan Workplace Dynamics in New Zealand Public Services (Public Service Association, Wellington, 2013).

${ }^{326}$ Leonie Walker NZNO employment survey 2017, Our nursing workforce: resilience in adversity (New Zealand Nurses Organisation, Wellington, 2017).

${ }^{327}$ Samuel Harvey, Sadhbh Joyce, Leona Tan, Anya Johnson, Helena Nguyen, Matthew Modini and Markus Groth Developing a mentally healthy workplace: A review of the literature A report for the National Mental Health Commission and Mentally Healthy Workplace Alliance (November 2014).

${ }^{328}$ National Occupational Health and Safety Commission National Occupational Health and Safety Commission Annual Report 2002-2003 (Canberra, NOSHC, 2003). A LaMontagne, K Sanderson and F Cocker "Estimating the Economic Benefits of Eliminating Job Strain as a Risk Factor for Depression" (2011) Occupational and Environmental Medicine 68, A3.

${ }^{329}$ OECD, above at $\mathrm{n} 10$, at 26.
}

113 
There is data from Australia, where work-related mental harm is compensable under their workers' compensation schemes and from which some extrapolation is possible. ${ }^{330}$ The Report of SafeWork Australia, The Incidence of Accepted Workers' Compensation Claims for Mental Stress, stated that such claims amount to about 10 per cent of the total claims made, but were the most expensive, requiring longer periods of absence from work. ${ }^{331}$ The highest number of claims was for "work pressure related illness." Harassment and bullying had the second highest number of claims, and then "exposure to workplace violence." 332 Claims increased with worker age, with men aged 55-59 and women 50-54 making the most claims. ${ }^{333}$ Younger workers were more likely to be exposed to occupational violence and women more likely to be sexually harassed. Women accounted for 58.6 per cent of mental stress claims (women making up only 33.6 per cent of total workplace injury claims). ${ }^{334}$ Those most at risk were drivers for public transport, law and order occupations, those in caring and health professions and teachers. ${ }^{335}$ The Australian statistics reflect many of the industry trends identified in the 2009 New Zealand study, which highlighted the prevalence of bullying and stress-related health problems in the health and education sectors. ${ }^{336}$

The rise in work-related mental health problems in Australia has been attributed to changes in the labour market and the nature of work, with more employees involved in "mental" work. ${ }^{337}$ These changes can also be seen in New Zealand. According to the latest New Zealand Sectors Report "services" make up 52 per cent of the total workforce, with government, education and health a further 28.1 per cent. This dwarfs the numbers of people employed in mining, primary industries, manufacturing and the booming

\footnotetext{
${ }^{330}$ SafeWork Australia, The Incidence of Accepted Workers' Compensation Claims for Mental Stress in Australia (April 2013).

${ }^{331}$ Above, at 6.

332 At 8.

${ }^{333}$ At 10 .

${ }^{334}$ At 9.

${ }^{335}$ At 11.

${ }^{336}$ Bentley Report, at i.

${ }^{337}$ See Chapter 2 of Commonwealth of Australia, National Review into Model Occupational Health and Safety Laws: First Report to the Workplace Relations Ministers' Council (October 2008) for discussion of the impact of changing labour market demographics on rates of work-related mental harm.
} 
construction sectors ( 35.5 per cent combined), ${ }^{338}$ which are the focus of occupational health and safety and injury prevention activity. Changes in the type of work being done in New Zealand results in changes to the types of hazards that workers are exposed to. Jobs in the health, education and service sectors typically tend to have hazard profiles that result in a higher risk of developing mental illness and stress related diseases than accidental physical injury. Service industries, education and health generated 90 per cent of job growth in New Zealand over 2002-2012, ${ }^{339}$ suggesting a growing number of people potentially affected. The numbers of people in New Zealand performing what could be described as primarily mental work, and thus exposed to the hazards of that work, are considerable. While not all service, health and education sector workers will develop health problems, it is important to ask why these workers are not entitled to ACC cover for the harms that logically result from the type of work they do.

\section{A gender divide in cover}

New Zealand's labour market remains highly segregated by gender, meaning that male and female workers tend to cluster in particular occupations. ${ }^{340}$ Different gendered patterns of work result in different patterns of hazard exposure, and different patterns of resulting health problems. Jobs in female-dominated industries (e.g. teaching, healthcare and administration) tend to have risk profiles associated with the development of chronic health problems, and in particular stress-related illnesses. ${ }^{341}$ The health conditions most likely to affect workers in female-dominated industries are the least likely to receive ACC cover, or are completely excluded from cover, leaving these workers without support and assistance. The chronic health effects of work also tend to receive less attention from the regulator, meaning there is less guidance and enforcement action focussed on female-dominated industries.

\footnotetext{
${ }^{338}$ Ministry of Business, Innovation and Employment New Zealand Sectors Report 2014: An Analysis of the New Zealand Economy by Sector (April 2014), at 39-50.

${ }^{339}$ At 39-45.

${ }^{340}$ Statistics New Zealand Women at Work: 1991-2013 (October 2015).

${ }^{341}$ SafeWork Australia Work-Related Mental Disorders Profile 2015 (SafeWork Australia, 2016).
} 
To understand the differences in treatment, it is useful to compare two workers, one performing traditionally "male work" in a male dominated occupation, such as a builder, ${ }^{342}$ and one performing traditionally "female work" in a female-dominated occupation, such as a social worker. ${ }^{343}$ Each job has a particular set of health risks associated with the work being performed. The risks associated with building work tend to involve accidental physical injury, for example falls from height injuries, crushing injuries, trench or scaffold collapse, electric shock and slips, trips and falls. ${ }^{344}$ The job of a social worker tends to have a risk profile associated with occupational violence (e.g. being assaulted by clients), compassion fatigue, traumatic stress, workload stress and burnout. ${ }^{345}$ While builders do face occupational health risks, ${ }^{346}$ most notably, respiratory and asbestos related illnesses and noise-related hearing loss, and social workers do have some risk of accidental physical injury such as tripping or being physically assaulted, the social worker's job is much more likely to result in mental health problems, for which there is the least support available.

If the social worker broke her leg as a result of falling from a ladder, she would receive the same treatment as the builder would for his. However, the risk of the social worker suffering this type of injury at work is very low. The type of work that the social worker performs places her at greater risk of mental health problems and stress-related illness, for

\footnotetext{
${ }^{342}$ Statistics New Zealand, above at n 340, men make up 98\% of workers in building trades.

${ }^{343}$ Above. Women make up approximately $85 \%$ of social workers. See also Rohhveig Dahle "Social work: A history of gender and class in the profession" (2012) 12(3) Ephemera 309; and Grace Khunou, Roshini Pillay and Angela Nethononda "Social work is women's work: An analysis of social work student's perceptions of gender as a career choice determinant" (2012) 24(1) The Social Work PractitionerResearcher 120.

${ }^{344}$ See ACC, ACC1174: How to Manage Hazards: For Construction (June 2013) and also the WorkSafe New Zealand Guides for the construction industry $<$ http://construction.worksafe.govt.nz/guides/>

${ }^{345}$ Brian Bride and Charles Figley, "The fatigue of compassionate social workers: An introduction to the special issue on compassion fatigue"(2007) 35 Clin Soc Work J 151; April Naturale "Secondary Traumatic Stress in Social Workers Responding to Disasters: Reports from the field" "(2007) 35 Clin Soc Work J 173, Chris Llyod, Robert King and Lesly Chenoweth "Social Work, Stress and Burnout: A Review" (2002) 11(3) Journal of Mental Health 255, and Annie Fahy "The Unbearable Fatigue of Compassion: Notes from a substances counselor who dreams of working at Starbucks” 35 Clin Soc Work J 199.

${ }^{346}$ See recent report by Kate Bryson and Anne Duncan Mental Health in the Construction Industry Scoping Study (BRANZ, 2018).
} 
which she would receive no cover. As set out above, the Australian workers' compensation data highlights that women are significantly more likely to make mental health claims than men. When analysed per hour worked, "women were three times more likely than men to have a claim caused by work-related harassment and/or workplace bullying (15 claims per 100 million hours worked compared with 5) and were twice as likely to have a claim caused by "exposure to workplace or occupational violence." ${ }^{347}$ There is currently no ACC cover for workers affected by harassment or bullying, whether sexual or otherwise, the psychological effects of occupational violence or any work pressure related illnesses.

It is clear from the international literature that it is not the worker's gender that makes them more likely to develop mental health problems, but the fact that the workers perform jobs that involve greater interaction with people. Safe Work Australia's Director of Data and Analysis recently emphasised that the "key determinant for work-related disease and injury is occupation rather than gender." ${ }^{448}$ When analysed on a per hour worked basis, male teachers, nurses and carers had about the same number of claims as their female colleagues. ${ }^{349}$ In Australia "64 per cent of mental disorder claims came from 4 of 19 industry divisions." ${ }^{350}$ Health care and social assistance, and public administration each made up 21 per cent of claims, with education and training a further 14 per cent. ${ }^{351}$

The types of occupations of workers receiving compensation for a work-related mental disorder tend to be those who work in occupations which involve high levels of interaction with other people, often rendering a service to the public and often doing their job in difficult and challenging circumstances. ${ }^{352}$

\footnotetext{
${ }^{347}$ SafeWork Australia, above at n 330, at 12.

${ }^{348}$ SafeWork Australia “International Women's Day: Reflecting on women's health and safety in the workplace" (2016) <http://www.safeworkaustralia.gov.au/sites/swa/news/pages/tn09072016>

${ }^{349}$ SafeWork Australia Work-Related Mental Disorders Profile 2015, at 11.

${ }^{350}$ Above, at 6 .

${ }^{351}$ Above.

352 SafeWork Australia “International Women's Day: Reflecting on women's health and safety in the workplace" (2016) available at http://www.safeworkaustralia.gov.au/sites/swa/news/pages/tn09072016
} 


\section{Māori potentially significantly affected}

While the lack of data makes understanding the exact make-up of the excluded group impossible, it is likely Māori are also disproportionately affected, due to higher rates of mental illness, higher rates of occupational hazard exposure in general and higher rates of reported work stress. ${ }^{353}$ This was highlighted in the 2018 OECD Report, which explicitly identified Māori as particularly impacted by the current limits of ACC cover (although not solely in relation to work-related illnesses). ${ }^{354}$ There has been some research in to Māori work-related mental health that suggests it is an area in need of particular attention. WorkSafe is also making this a priority under its new Maruiti 2025 Strategy, through which it seeks to reduce rates of Māori death, injury and illness to the current rates of non-Māori (or lower). ${ }^{355}$ In 2010 Mauri Ora Associates produced a report for the previous Department of Labour on Māori experiences with ACC. ${ }^{356}$ This report highlighted that Māori receive less cover than non-Māori, and also have worse experiences in making claims. ${ }^{357}$ The report indicated fewer work-related claims were accepted by ACC $(9.47 \%$ of earners' account claims, compared to $11.47 \%$ of the workforce). ${ }^{358}$

Māori occupational patterns suggest differing patterns of hazard exposures that likely result in differing patterns of work-related injury and illness. ${ }^{359}$ A significant 2011 study identified ethnic differences in occupational exposures in New Zealand. ${ }^{360}$ The study found that there were differences in hazard exposure, due "in large part" to differences in occupational distribution, with Māori over-represented in low-skilled, manual (e.g. manufacturing, forestry) and elementary occupations (e.g. cleaning, labouring) which are

\footnotetext{
${ }^{353}$ Eng, Mannetje, Ellison-Loschmann, McLean, Cheng and Pearce, above at n 198.

${ }^{354}$ OECD Report, above, at $\mathrm{n} 10$.

355 The Maruiti Strategy targets can be accessed on the WorkSafe New Zealand website

$<$ https://worksafe.govt.nz/about-us/who-we-are/our-priorities/maruiti/>

${ }^{356}$ Mauri Ora Associates Maori Experience of ACC: Final Report to the Department of Labour (Maori Ora Associates, 2010).

${ }^{357}$ Above.

${ }^{358}$ Above, at 6.

${ }^{359}$ See John Gould "Maori- Pakeha occupational segregation and earnings differentials: A comment" (2003) 29(2) New Zealand Population Review 1.

${ }^{360}$ Eng, Mannetje, Ellison-Loschmann, McLean, Cheng and Pearce, above at n 198.
} 
typically more hazardous. ${ }^{361}$ The study also found, however, increased exposure rates for Māori within the same occupational title. ${ }^{362}$ Particularly noteworthy were differences in reported stress, with Māori women more likely to report their jobs as very or extremely stressful than any other group. This was attributed to a combination of increased psychosocial risk factors, the impact of racism and discrimination, and poorer work life balance due to the performance of a larger share of unpaid work. ${ }^{363}$

\section{$V$ Inconsistency with Health and Safety Laws}

The current cover provisions of the ACC scheme jar with the approaches of the occupational health and safety legislation. The new HSWA, which came in to force in April 2016, and the former Health and Safety in Employment Act 1992 (HSEA), provide for no difference in the employer's obligations to prevent mental or physical harm to employees. Nor is there a difference in the legal obligations to prevent acute or chronic occupational diseases. Since 2004 "harm" has been defined to mean "illness, injury, or both" and

expressly includes "physical or mental harm caused by work-related stress." 364 Applying the risk management approach required under the legislation our starting assumption is that each job has a set of hazards associated with the work being done, or working environment, that are "an actual or potential source of harm." 365

As highlighted in Chapter One, the differences in ACC treatment and the lack of available data on excluded health conditions contribute to New Zealand's poor health and safety response in this area. The lack of data, resulting from the lack of ACC cover, has resulted in the exclusion of these health conditions from current policy and targets. Targets drive decisions about resources and enforcement activity, and the exclusion of these conditions

\footnotetext{
361 At 416.

362 Above.

${ }^{363}$ At 417.

364 "Hazard," HSEA, s 2.

365 Above.
} 
from the national targets creates a real risk of continued exclusion from health and safety policy priorities in the future.

While New Zealand's health and safety failures result from a combination of factors, including a lack of enforcement powers and resources, there is no question that in relation to occupational health, ACC is part of the problem. The ACC scheme is a significant, but sometimes overlooked, part of New Zealand's occupational health and safety regime. As discussed in Chapter One, its "primary function" under statute is to "reduce the incidence and severity of personal injury" and to provide "a framework for the collection, coordination, and analysis of injury related information." ${ }^{366}$ The work-related cover provisions should be operating in alignment with the health and safety regime and primarily toward the goals of reducing injury and illness.

\section{A The problem with "accident" for health and safety}

The negative consequences of the current ACA drafting for work health and safety in New Zealand extend beyond the operational. The centrality of the concept of "accident" to the scheme has an unfortunate impact on the assumptions and practices of government officials and employers. There have been several decades of literature critiquing the notion of "accident" and its impact on health and safety. ${ }^{367}$ Accident tends to imply one of two things; either the harm the worker suffered was sudden, unavoidable and unpredictable; or the harm occurred because of some personal defect, carelessness or inadvertence on the part of the individual.

\footnotetext{
366 ACA, s 3.

${ }^{367}$ See Nichols, above at n 202Error! Bookmark not defined., at 2-3; Philip Bohle "Work Psychology and the Management of Occupational Health and Safety: An Overview" in Michael Quinlan (ed) Work and Health: The Origins, Management and Regulation of Occupational Illness (Macmillan, Melbourne, 1993); William Breen Creighton, William Ford and Richard Mitchell Labour Law: Text and Materials $\left(2^{\text {nd }}\right.$ ed, Law Book Co, Sydney, 1993), at 1340; and Harry Glasbeek, above at n 43, at 99.
} 
The concept of "accident" implies a particular causal relationship between work and the harm suffered by the worker. In relation to the first point, Nichols notes: ${ }^{368}$

... accident carries with it too much conceptual baggage, some of which can be misleading...the term accident carries connotations of that which is unanticipated, that which is unintentional and that which is down to misfortune or bad luck.

Likewise, Bohle considered that the use of the term in Australia "carries the unfortunate implication that injuries are unavoidable, random events." ${ }^{369}$ This is a significant problem for health and safety as it fails to acknowledge the impact of specific business decisions about the workplace and the performance of work that contribute to the harm. A workrelated injury or illness will often stand at the end of a long causal chain involving decisions about business priorities, resource allocation, plant and equipment, rostering and staffing, hours of operation and human resources practices. Viewing the harms arising from work as "accidents" also implies that they are to some extent an inevitable consequence of business activities and thus never really preventable, excusing poor performance. Glasbeek outlined in his 1998 critique: ${ }^{370}$

Thinking of occupational health and safety problems as the materialisation of risks, which inhere in all productive activity, gives force to the argument that the materialisation of risk is an undesired event, one which all people involved in production work hard to prevent.

The second unfortunate implication of the term "accident" is that the cause of the harm must be the character, personality or defects of the worker harmed. There is strong "victim blaming" discourse in much of the organisational psychology literature, following a line of "accident proneness" research. ${ }^{371}$ Accident proneness research started with investigations into rates of injuries in women working in English munitions factories during the First World $\mathrm{War}^{372}$ and was "picked up by the whole wave of industrial psychologists in the United States who searched for the causes of accidents in the psychology of individual

\footnotetext{
${ }^{368}$ Nichols above, at $\mathrm{n} 202$, at 2-3.

${ }^{369}$ Nichols, above. Bohle, above at $\mathrm{n} 367$.

${ }^{370}$ Glasbeek, above at $\mathrm{n} 43$, at 99 .

${ }^{371}$ Quinlan, above at $\mathrm{n} 201$.

${ }^{372}$ Major Greenwood and Hilda M Woods Industrial Fatigue Research Board Report No 4: The Incidence of Industrial Accident upon Individuals (HSMO, London, 1919).
} 
workers." "373 The early research claimed "evidence to show that accident incidence... depends largely on some quality of susceptibility inherent in the personality of the victim." 374 It also provided the "grounds for thinking that the bulk of accidents may occur amongst a limited number of individuals having a special personality susceptibility to accidents." ${ }^{375}$ Researchers such as Stephenson ${ }^{376}$ would conclude that "safety training was [not] of any use for those workers who were not susceptible" 377 and improving the selection of workers and developing tools for scientific selection became a focus of the literature.

\section{B "Accident" and the HSWA}

The centrality of the concept of "accident" within the ACC scheme could be seen as having a particularly dangerous impact on health and safety in New Zealand in combination with the assumptions underpinning the HSWA. The New Zealand health and safety legislation has, since the 1990s, been based on what is called the "Robens Model" of health and safety regulation, and is largely similar, but in a weaker form, to that in Australia and England. The Robens Model arose out of the Report of the British Parliamentary Committee on Safety and Health and Work in 1972, chaired by Lord Robens (Robens Report). ${ }^{378}$ The Robens Model, while representing an advancement on the prior regime, had some highly questionable assumptions about the nature of "industrial accidents" and their cause. For Robens "apathy" was the "most important single reason for accidents at work." 379 Robens took the unitarist view that that "there is greater natural identity of interests between the two sides" in relation to health and safety than other employment relations matters. ${ }^{380}$

\footnotetext{
${ }^{373}$ Nichols, above at n 202, at 63.

374 Industrial Fatigue Research Board Social Annual Report to 30 $0^{\text {th }}$ September 1921 (HMSO, London, 1922), at 23.

${ }^{375}$ Industrial Fatigue Research Board Report 19: Two contributions to the study of accident causation (HMSO, London, 1922), at vii.

${ }^{376}$ A Stephenson "Industrial accidents" in C S Myers (ed) Industrial Psychology (Thornton Butterworth, London, 1929) at 129.

377 Above, at 132.

378 Robens Report, above at n 42.

${ }^{379}$ Robens Report, above, at para 1.

${ }^{380}$ Robens Report, at para 66.
}

122 
Starting with the assumption that there is such an alignment of interests then leads to the conclusion, as Robens drew, that accidents must result only when parties fail to act in their own best interests, namely where there is carelessness, ignorance or apathy.

Within the Robens model it is inadvertence, apathy or ignorance which is fundamentally the cause of workplace injuries, not conscious decisions about work allocation, equipment purchase and maintenance, resource allocation decisions, remuneration or human resources practices. The assumption has a direct consequence on the policy decisions made about enforcement, regulatory design and regulator function. If it is simply apathy that is the problem, and not the social relations of work, the right answer must be reminding workers to take greater care, rather than the critical evaluation of the nature of the work, who is performing it, and under what conditions. In New Zealand, the Robens assumptions reinforce notions of "accident" and can be seen in ACC's frequent "Think Safe at Work" campaigns, distributing posters to workplaces containing reminders to guard against apathy in the name of injury prevention.

Nichols argued that Robens was not only wrong in his conclusion that apathy was the problem, but "disastrously wrong." 381 Starting with such an assumption it can "be further assumed that safety systems operate relatively uninfluenced by the demands of production and independently of the larger economic systems." ${ }^{382}$ These assumptions fed in to calls for deregulation and the removal of technical standards and specific requirements. While much of the scholarly criticism relates to the Australian health and safety laws, the points made are perhaps even more pertinent in New Zealand, where an even greater deregulation of health and safety occurred and was coupled with the elimination of common law rights to sue, systemic underfunding, few prosecutions and a weakened regulator. Gunningham outlines the contribution that the neoliberal regime era choices made to New Zealand's poor health and safety record and the Pike River Mine Tragedy. ${ }^{383}$ The cause of New

\footnotetext{
${ }^{381}$ Nichols, above at n 202, at 52.

382 Above, at 43 .

${ }^{383}$ Gunningham, above at n 238; See also J Ryan Lamare, Felicity Lamm, Nadine McDonnell and Helen White "Independent, dependent and employee: Contractors and New Zealand's Pike River Coal Mine
} 
Zealand's failings in relation to occupational health and safety are complex and multifaceted, but the dominance of "accident" in the health and safety language, the assumption that apathy is the root cause of workplace injury, and the lack of reliable data is potentially a significant part of it.

\section{Conclusion}

The current ACA has significant gaps in the cover of work-related health problems, especially chronic health problems falling outside the definition of "accident" in section 25. This thesis asserts that the current gaps in cover can be viewed as a logical consequence of the original political decision to design the scheme around the concept of "accident". "Accident" provides no basis in principle to distinguish between different types of harm suffered, and in the absence of an underlying policy rationale, the legislative provisions come to focus on the diagnostic specifics of where and how in the body a medical condition came to be. Resulting from the "body-focus" of the legislation and the need to draw lines between health conditions the current coverage tests effectively codify understandings of disease that are now outdated or may well become so.

The changing nature of work, medical thinking and the resulting change in the relationships between work and health are challenging to all forms of compensation regime. The New Zealand ACC scheme is, however, in a particularly poor position to respond to these trends because of the multiple layers of structural tension within its coverage provisions. The concept of "accident" is central to the current ACC scheme, but detrimental to work health and safety, and increasingly limiting and unworkable. Effectively addressing the chronic health effects of work and better responding to the needs of New Zealand's workforce requires a departure from the notion of "accident" in the country's health and safety and compensation laws

disaster" (2015) 57(1) JIR 72; and Felicity Lamm and Marjolein Lips-Wiersma "A disaster waiting to happen: Silently silencing stakeholders at the Pike River Coal Mine” (2018) 60(4) JIR 560. 


\title{
CHAPTER FIVE: THE URGENT CHALLENGES OF WORK- STRESS-RELATED HEALTH PROBLEMS
}

\author{
Key Areas for Reform
}

\section{Introduction}

The work performed in New Zealand has changed a great deal since Woodhouse was writing in the 1960s. There have also been significant advances in medical thinking over the past fifty years which have fundamentally altered the way we think about the relationships between work and health. The previous chapter outlined the gaps in the current ACA cover provisions and the consequences of these gaps for work health and safety. This chapter builds on that review, allowing for a greater depth of analysis into the areas in most urgent need of reform. In particular, any future versions of the ACC scheme will need to address what are referred to in the literature as the "big three" of work-stressrelated conditions: depression/anxiety, cardiovascular disease and chronic musculoskeletal disorders. These are some of the most common, and growing, work-related health problems affecting the workforce, with cardiovascular disease being New Zealand's leading cause of death, depression ranked as one of the world's most significant future health issues, and musculoskeletal disorders being the largest cause of work-related disability. ${ }^{384}$

\footnotetext{
${ }^{384}$ Ischemic heart disease is the leading cause of death for Maori and non-Maori males and non-Maori females, and second leading cause of death for Maori females, but top overall in the New Zealand population. Statistics available on the New Zealand Ministry of Health website $<$ http://www.health.govt.nz/our-work/populations/maorihealth/tatau-kahukura-maori-health-statistics/ngamana-hauora-tutohu-health-status-indicators/major-causes-death $>$; See also WHO "Cardiovascular Diseases Factsheet" (May 2017) <http://www.who.int/mediacentre/factsheets/fs317/en/> Statistics on depression and suicide available on the New Zealand Ministry of Health website $<$ http://www.health.govt.nz/ourwork/populations/maori-health/tatau-kahukura-maori-health-statistics/ngamana-hauora-tutohu-health-statusindicators/major-causes-death>; See also C Mathers and D Loncar "Projections of global mortality and burden of disease from 2002 to 2030" (2006) 3(11) PLoS Medicine e442.
} 
This chapter provides an overview of the current academic discussion of cardiovascular disease, depression, and lower back pain and their relationships to work-stress, highlighting some of the key causal complexities at issue for future iterations of the ACC legislation. First, a brief overview of the key trends in the growth of stressful work since the Woodhouse Report was written is provided. Second, a brief survey of the parallel rise in stress-related health problems is presented, focusing on the selected stress-related illnesses. The aim of this is not to advance any particular view about the science of these conditions, but rather to highlight the gaps between the current medical thinking and the current state of the law, and to enable the development of a model of law reform in the following chapters.

\title{
II The Rise of Stressful Work in New Zealand
}

There is a considerable local and international literature documenting the changes to work and the workforce which have occurred since the Woodhouse Report was released in 1967. The pace of change looks set to continue, if not increase, with many commentators heralding a fourth industrial revolution: ${ }^{385}$

\begin{abstract}
The possibilities of billions of people connected by mobile devices, with unprecedented processing power, storage capacity, and access to knowledge, are unlimited. And these possibilities will be multiplied by emerging technology breakthroughs in fields such as artificial intelligence, robotics, the Internet of Things, autonomous vehicles, 3-D printing, nanotechnology, biotechnology, materials science, energy storage, and quantum computing.
\end{abstract}

The changes to work and the workforce which have occurred, and which are continuing to occur, are complex, interrelated and unevenly distributed. This chapter can only highlight several key trends that have a particular impact on the development of stress-related illnesses providing a context to frame the discussion of causation and the development of the new causal test in the following chapters.

\footnotetext{
${ }^{385}$ See commentary by Klaus Schwab, Chairman of World Economic Forum "The Fourth Industrial Revolution: What it means, how to respond" (14 January 2016) first published in Foreign Affairs and available on the World Economic Forum Website $<$ https://www.weforum.org/agenda/2016/01/the-fourthindustrial-revolution-what-it-means-and-how-to-respond/>
} 


\section{A The Decline of Manufacturing and the Rise of "Services"}

As in most other OECD economies, New Zealand experienced a sharp rise in the proportion of the workforce engaged in what has variously been described as "the service sector" and declines in primary industries and manufacturing. ${ }^{386}$ Within the vague expression of "services," further developments and shifts have taken place. "Caring jobs" have risen, with sharp growth in early childhood care, education, nursing, health care and aged care. ${ }^{387}$ Further, significant growth in these areas is also predicted over the next decades. ${ }^{388}$ As the nature of the work performed changes, so too, do the types of hazards that workers are exposed to. As has occurred in other developed countries, the decline of manufacturing, mining and heavy industries has reduced the numbers of the workforce exposed to the hazards of unguarded machinery, mine collapse and logging. New Zealand has seen a decline in total numbers of injuries and deaths resulting from this work, although rates in New Zealand are still significantly higher (per capita and per hours worked) than in comparable jurisdictions. ${ }^{389}$

The parallel rise in "services," including the growth in public services, education and caring jobs have seen increases in chronic musculoskeletal diseases and stress-related illnesses, particularly mental illness, in comparable countries. ${ }^{390}$ Service roles, although vast and various in nature, typically involve greater mental or emotional load, and greater interactions with people, such as patients, clients, students, patrons or colleagues, and, as discussed further below, are often performed in "intensified" environments, with newer

\footnotetext{
${ }^{386}$ Latest New Zealand Household Labour Force Survey data is available on the Statistics New Zealand website

$<$ http://archive.stats.govt.nz/browse_for_stats/education_and_training/Tertiary\%20education/unistats/produ cts-and-services/household-labour-force-survey-data-package.aspx>

387 Above.

388 Above.

${ }^{389}$ See WorkSafe New Zealand, above at n 29. See most recent data on Statistics New Zealand website: $<$ https://www.stats.govt.nz/> (Note: at time of submission there were a number of problems identified in Census collected and ACC data, meaning that figures could not be released to the public).

${ }^{390}$ Yves Roquelaure Report 142: Musculoskeletal disorder and psychosocial factors at work (European Trade Union Institute, Brussels, 2018); Country studies on mental health at work are available on the OECD website < https://www.oecd.org/employment/mental-health-and-work.htm>.
} 
forms of monitoring and management, increasing the likelihood of stress, bullying and occupational violence.

The following diagrams display the shifts which have occurred in the New Zealand economy from the 1960s. There are some data difficulties that make exact comparison over this period difficult, but the graphs indicate a general decline in manufacturing and manual occupations, and a clear rise in the numbers of New Zealand workers employed in "services". Table A provides for industrial and sectoral employment patterns from 1960 to 1992, highlighting the period of greatest transition. ${ }^{391}$ Table B below then shows changes in industry employment in the period from 1989-2012, 392 and the final graph, Table C, shows the recent years' trends to 2017. There have been significant problems and delays in the release of the 2018 Census data, which is why more sophisticated analysis after 2012 was not possible at the time of submission. ${ }^{393}$

\footnotetext{
${ }^{391}$ Graph sourced from Bryan Philpott Provisional Estimates for 1990 - 1998 of Output, Labour and Capital Employed by SNA Industry Group RPEP Paper 265 (New Zealand Treasury, Wellington, 1994), at 21.

${ }^{392}$ Graph sourced from Nick Carrol, New Zealand Treasury Report: Structural Change in the New Zealand Economy 1974-2012 (New Zealand Treasury, Wellington, 2012).
} 
Table A: Long-term industrial and sectoral employment (FTE) change in the New Zealand economy (1960-92)

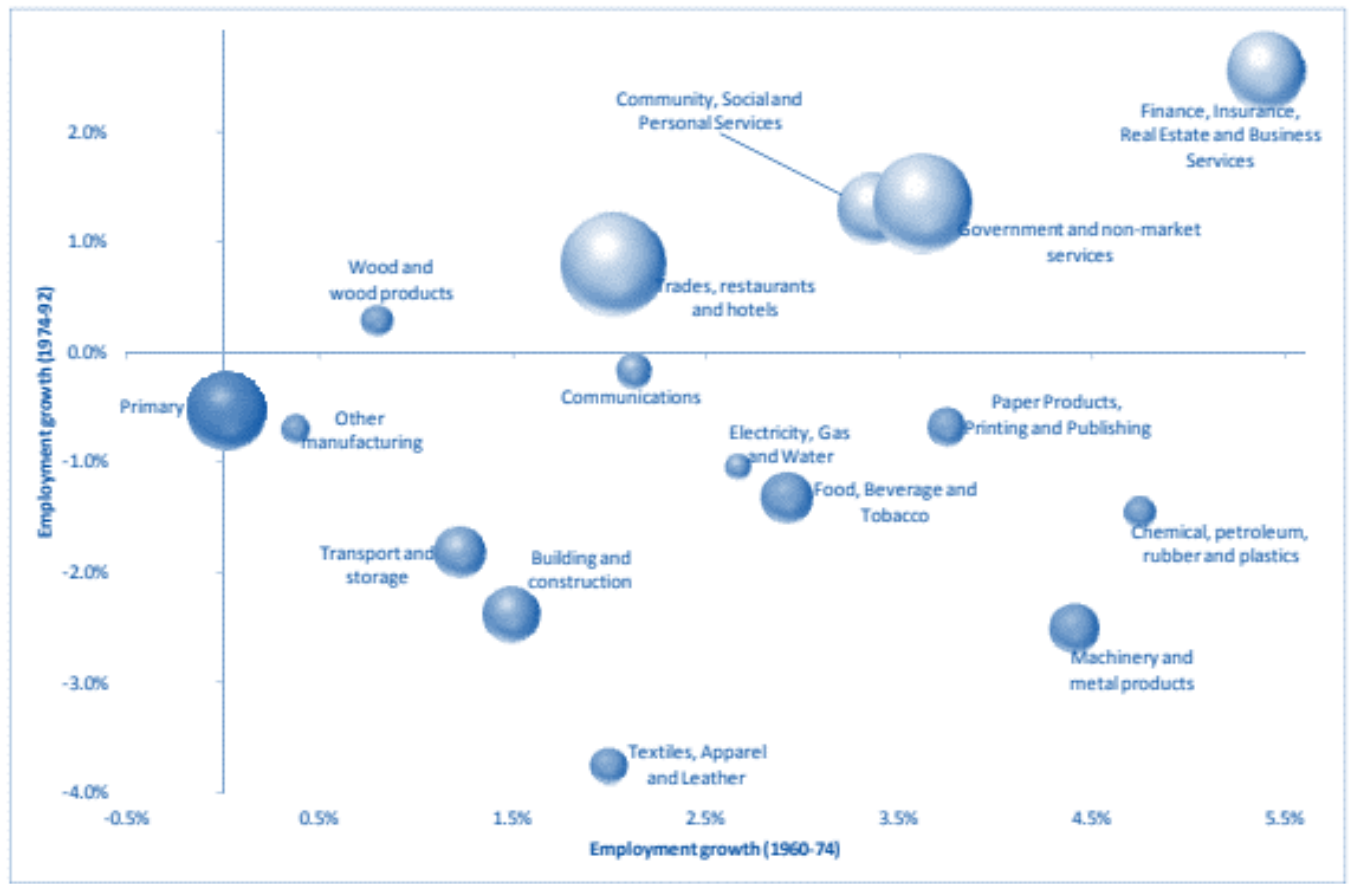

Table B: Change in industry employment 1989-2012

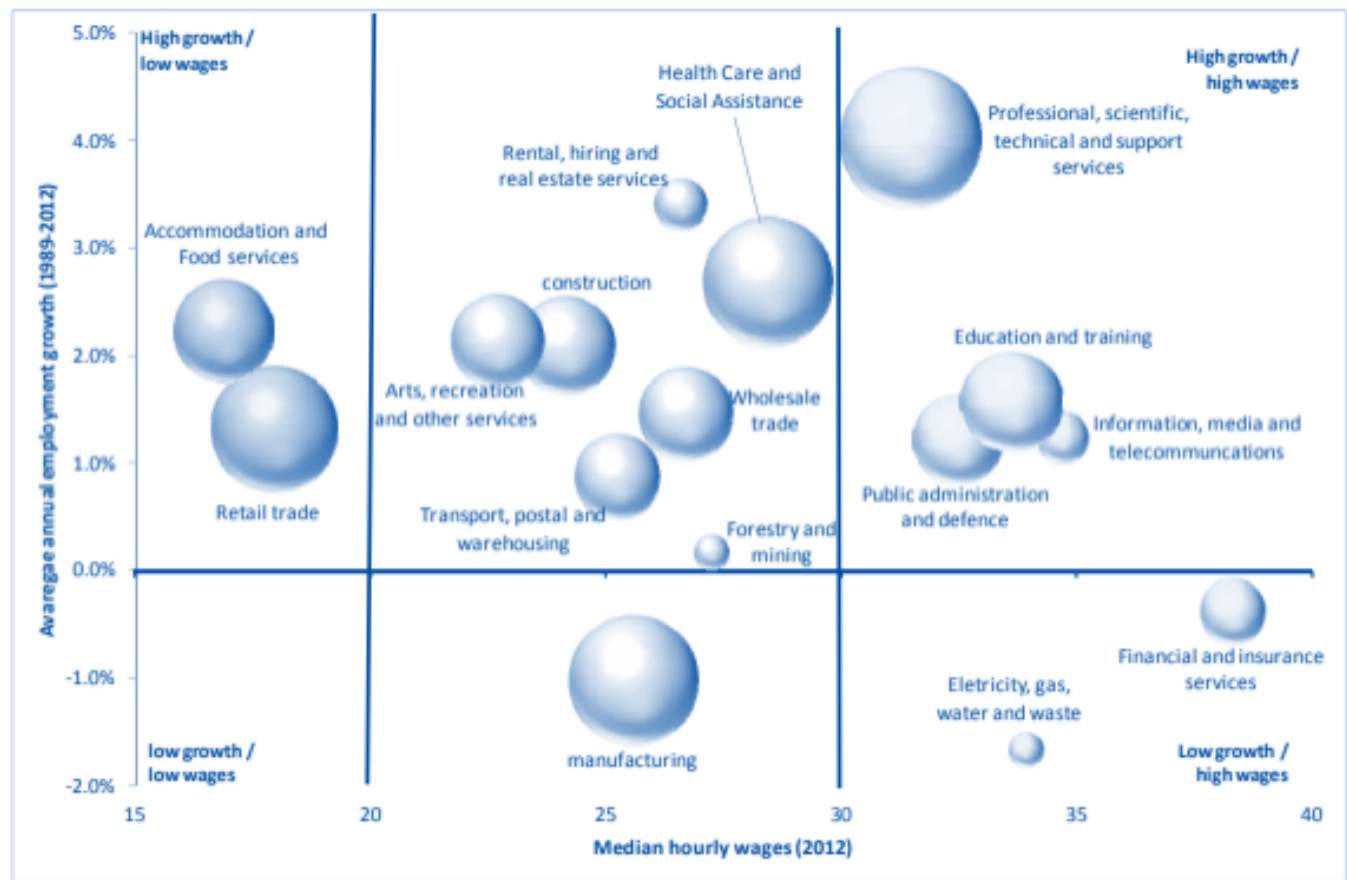


Table C Recent years' trends 2007-2017

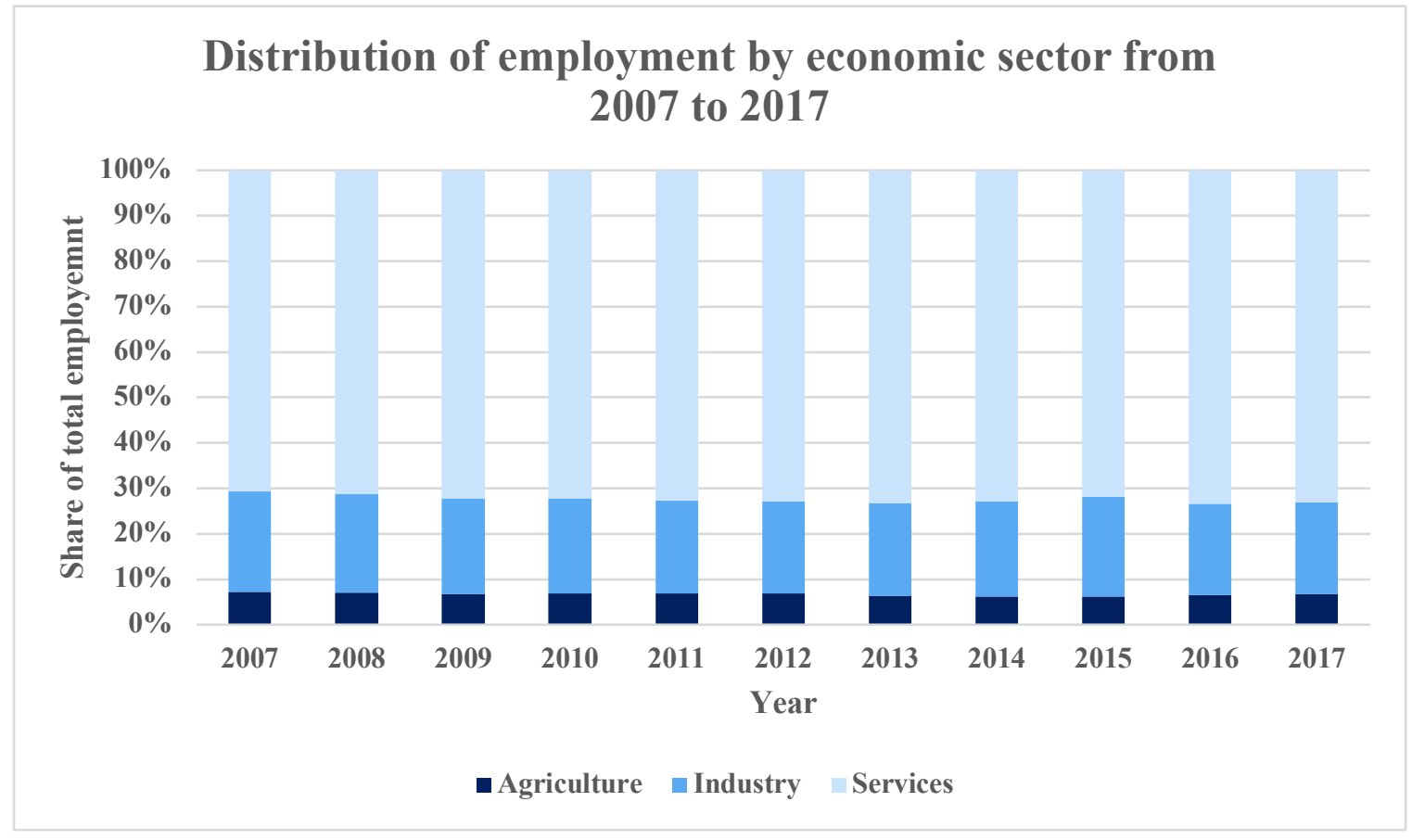

\section{Changes to the Organisation and Management of Work}

As the nature of the work being performed has changed, so to, theories of managing work and the workforce have changed with them. Getting workers to perform newer forms of work in the most productive and efficient manner required a shift in management approach. According to Bryson, over the past forty years New Zealand has seen "a fundamental and ongoing change in the administration of workplace relationships:"394

In New Zealand organisations, neoliberal policies, bolstered by ICT capabilities, established a shift from administering awards to managing employer risk and organisational image'

394 Jane Bryson "Administering workplace relationships: From IR to HR” in Gordon Anderson, Alan Geare, Erling Rasmussen and Margaret Wilson (eds) Transforming Workplace Relations in New Zealand 1976-2016 (Victoria University Press, Wellington, 2017), at 60. 
Looking at the trends in research from the 1960s, Väänänen, Murray and Kuokkanen ${ }^{395}$ identified a shift in the focus of articles published in management journals, with authors viewing work as something to be analysed using "human centred discourses" and "applying psychosocial approaches that take more account of the emotional wellbeing of workers."396

\section{A The pursuit of employee engagement}

Much of the human resources literature of recent decades has focussed on the goal of improving "employee engagement." Engagement was originally defined in the 1990s as: 397

...the harnessing of an organisation's members selves to their work roles by which they employ and express themselves physically, cognitively, and emotionally during role performances.

It was developed further as "a positive and fulfilling, work-related state of mind characterised by vigour, dedication, and absorption," 398 and as "feeling responsible for and committed to superior job performance." ${ }^{399}$ Engagement has been asserted to result in greater productivity, quality, profitability, shareholder return and customer satisfaction as well as lower absenteeism and turnover. ${ }^{400}$

\footnotetext{
${ }^{395}$ Ari Väänänen, Michael Murray and Anna Kuokkanen "The growth and stagnation of work stress: Publication trends and scientific representations 1960-2011" (2014) 27(4) History of the Human Sciences 116.

${ }^{396}$ Above, at 125.

${ }^{397}$ W Kahn "Psychological conditions of personal engagement and disengagement at work" (1990) 33 Academy of Management Journal 692, at 694.

${ }^{398}$ W Schaufeli, M Salanova, V Gonzalez-Roma and A Bakker "The measurement of engagement and burnout: A two sample confirmatory factor analytic approach" (2002) 3 Journal of Happiness Studies 71, at 74.

${ }^{399} \mathrm{~T}$ Britt "Engineering the self in the field: Testing the triangle model of responsibility" (1999) 25 Personality and Psychology Bulletin 696; and T Britt "Aspects of identity predict engagement in work under adverse conditions" (2003) 2 Self and Identity 31.

${ }^{400} \mathrm{R}$ Wellins, P Berthal and M Phelps Employee engagement: The key to realising competitive advantage (Development Dimensions International, Online, 2005).
} 
Engagement, however, has a dark side for employee health, which recent research is beginning to make clear. ${ }^{401}$ Put simply, the greater mental and emotional engagement of the worker in their job, the more vulnerable they are to developing stress-related illnesses. Recent research has highlighted the risks for "highly engaged employees" ${ }^{402}$ As set out by MacCormick and others, "with too much engagement [e]nergy turns to exhaustion, involvement turns in to cynicism, and efficacy is rendered ineffective" $" 403$ The concept of "burnout" was advanced by Jackson and Maslach in 1981 and has become a feature of the contemporary occupational health and organisational psychology literature. ${ }^{404}$

\section{B Increased demand for connection}

Shifts in the nature of work, and the resulting increase in mental and emotional load, have been heightened by the rapid increase in the use of communication technologies. There is a growing field of "connectivity" research that explores the shifting requirements for human connection, facilitated by technology and otherwise. While many workers experience what is described in the field as "a state of flow," 405 representing an optimal level of connectivity, there are a great many who experience what is described as "hyper connectivity," "constant connectivity" or "ubiquitous connectivity" 406 in which there is too

\footnotetext{
${ }^{401}$ Eean Crawford and Jeffry LePine "Linking job demands and resources to employee engagement and burnout: A theoretical extension and meta-analytic test" (2010) 95 Journal of Applied Psychology 834; and C Maslach and M Leiter Early predictors of job burnout and engagement" (2008) 93 Journal of Applied Psychology 93498.

402 J Moeller, Z Ivcevic, A E White, V Menges and M A Brackett "Highly engaged but burnt-out: Intraindividual profiles in the US Workforce (2018) OSF Preprints online. See also Emma Seppälä and Julie Moeller "1 in 5 employees highly engaged and at risk of burnout" in Harvard Business Review online (16 May 2018) <https://hbr.org/2018/02/1-in-5-highly-engaged-employees-is-at-risk-of-burnout>

${ }^{403}$ Judith MacCormick, Kristine Dery and Darl Kolb "Engaged or just connected? Smart phones and employee engagement.” (2012) 41 Organisational Dynamics 194, at 195.

${ }^{404}$ Susan Jackson and Christina Maslach "After effects of job-related stress: Families as victims" (1981) 3 Journal of Occupational Behaviour 63.

${ }^{405}$ Darl Kolb, Paul Collins and Allan Lind "Requisite connectivity: Finding flow in a not-so-flat world" (2008) 37(2) Organisation Dynamics 181, at 183.

${ }^{406}$ J Wajcman and E Rose "Constant connectivity: Rethinking interruptions at work" (2011) 32 Organisation Studies 941.
}

132 
much connection, "so much that it undermines performance, invades our personal space, wastes time, and /or produces stress and anxiety." ${ }^{407}$ Hyper-connectivity is a source of, or exacerbator of, work-related stress. Lundberg and Cooper explain that: 408

\begin{abstract}
Modern communication technology, including the internet, emails, laptops and mobile phones, has had a dramatic effect on work conditions. This development has been combined with extensive economic changes, globalisation of economies, deregulation of the labour market (outsourcing, offshore manufacturing, lean production) and more flexible and insecure forms of employment (part-time work, temporary employment). The speed of development of communication and computerised technology is increasing.
\end{abstract}

For example, work on the use of smart phones found that the devices "raised the engagement expectation baseline in many organisations." $" 409$ The devices also speed up the ability to generate data or information faster, creating an obligation on workers to use that information faster. This is coupled with "increasingly lean organisations," forced to "do more with less", and pressure on workers to work ever harder in order to advance, or even retain their jobs. MacCormick, Dery and Kolb found that this resulted in workers feeling as if they were constantly on call: 410

The "anytime/anywhere" connectivity enabled by smart phones means that employees can work longer hours (duration), access better quality data whenever they need it (intensity), and broaden the scope for work involvement (direction). Users can carry their work with them and engage in work activities in locations and at times that were previously outside of work limits. Work intensity increases when information flow increases, and work duration increases when connectivity becomes ubiquitous and continuous.

Even in a face-to-face context, some studies have highlighted the perils of "too much talking" "11 and constant "intensive collaboration."

Professionals need to disconnect in order to do generative tasks, like writing reports, but many have to do this at home to avoid the interruptions they will inevitably get at work... shared calendars

\footnotetext{
${ }^{407}$ Darl Kolb, Paul Collins and Allan Lind, above at n 405, at 186.

${ }^{408}$ Ulf Lundberg and Cary L Cooper The Science of Occupational Health: Stress, Psychobiology and the New World of Work (Wiley-Blackwell, Online, 2010), at 135.

${ }^{409}$ MacCormick, Dery and Kolb, above at n 403, at 195.

410 Above.

${ }^{411}$ Kolb, Collins and Lind, above at n 405, at 185.

412 Above.
} 
corner many professionals in to nonstop unwanted meetings and days without lunch because of a barrage of 'accept' and 'decline' buttons.

This greater engagement, connection and collaboration results in greater emotional load and greater risk of stress-related illness.

\section{Work intensification}

Related to the pursuit of greater engagement and connection is work intensification. Work intensification is defined as a process "characterized by an intensification of work effort" ${ }^{413}$ The term relates to the intensive effort that is needed to complete more tasks within the working day, as opposed to an increase in working hours, which is described as "work extensification." Work intensification and extensification do not necessarily occur together, as work may become more intense, without the worker necessarily performing more hours. Researchers characterise intensification as "the need to work faster and face tighter deadlines, by a reduction of idle time and the need to conduct a number of work tasks simultaneously". ${ }^{414}$ Measuring the intensification of work is complex and disputed. ${ }^{415}$ That said, there has been a significant number of studies into the phenomena of intensification and further studies on the resulting health impacts of intensification. ${ }^{416}$

\footnotetext{
${ }^{413}$ Matea Paskvan and Bettina Kubicek "The intensification of Work", in Christian Korunka and Bettina Kubicek (eds) Job demands in a changing world of work (Springer, eBook, 2017), at 26.

${ }^{414}$ Francis Green "Work intensification, discretion, and the decline in well-being at work" (2004) 30(4) Eastern Economic Journal 615; B Kubicek, M Paškvan and C Korunka, "Development and validation of an instrument for assessing job demands arising from accelerated change: The intensification of job demands scale (IDS)" (2005) 24(6) European Journal of Work and Organizational Psychology 898.

${ }^{415}$ See discussion in Francis Green Demanding work: The paradox of job quality in the affluent economy (Princeton Uni Press, 2006, e Book); and more recent discussion in Korunka and Kubicek, above at n 413; See also Eurofound First findings: Sixth European working conditions survey (2015) $<\mathrm{http}$ //www.eurofound.europa.eu/publications/resume/2015/working-conditions/first-findings-sixtheuropean-working-conditions-survey-resume>

${ }^{416}$ James Chowhan, Margaret Denton, Catherine Brookman, Sharon Davies, Firat K. Sayin, Isik Zeytinoglu "Work intensification and health outcomes of health sector workers" (2019) Personnel Review 48(2) 342; Erich C. Fein, Natalie Skinner and M. Anthony Machin "Work Intensification, Work-Life Interference, Stress, and Well-Being in Australian Workers" (2017) 47(4) International Studies of Management \& Organization 360; J Boekhorst, P Singh and R Burke, "Work intensity, emotional exhaustion and life satisfaction: The moderating role of psychological detachment"
} 
Work intensification has been shown to "increase... work effort, boost the productivity of an organization and ensure the economic profitability of companies." ${ }^{417}$ Research however, also suggests the impact on employees is largely negative, with short term gains in profitability followed by worker ill health. Studies have shown that work intensification is associated with strain indicators, ${ }^{418}$ reduced work-home balance, ${ }^{419}$ heightened work-home conflict ${ }^{420}$ and a reduction in employee job satisfaction. ${ }^{421}$

Intensification is seen by some as the logical consequence of economic globalisation and deregulation: ${ }^{422}$

Beginning in the 1980s in the United States and in the United Kingdom and further fostered by the collapse of the communist countries, there has been a strong development towards free market politics and reduced governmental control in many countries. "Neoliberalism" as the political foundation of free trade and globalization is leading to increased competition in practically all sectors of industry, production, trade and services. The economic pressure on production and services is thereby increasingly affecting many places of work. Longer working hours and reduced job security are just a few consequences on the employees' side.

Essentially, organisations are forced to change, and at an increasing speed, in order to remain competitive in global markets. This impacts on individuals and the work being

(2017) 46(5) Personnel Review 891; F Franke “Is work intensification extra stress?" (2015) 14(1) Journal of Personnel Psychology 17.

${ }^{417}$ Paskvan and Kubicek, above at n 413, at 31; See also F Green "It's been a hard day's night: The concentration and intensification of work in late twentieth-century Britain" (2001) 39(1) British Journal of Industrial Relations 53; and A Valeyre "Forms of work intensification and economic performance in French manufacturing" (2004) 30(4) Eastern Economic Journal 643.

${ }^{418}$ Green, above at $\mathrm{n}$ 417; Francis Green Demanding work: The paradox of job quality in the affluent economy (Princeton Uni Press, e Book, 2006); C Allan, P Brosnan and P Walsh "Human resources strategies, workplace reforms, and industrial restructuring in Australia and New Zealand" (1999) 10(5) Int J HRM 828.

${ }^{419}$ Keith Macky and Peter Boxall "High-involvement work processes, work intensification and employee well-being: a study of New Zealand worker experiences" (2008) 46(2) Asia Pacific Journal of Human Resources 38-55

${ }^{420} \mathrm{~B}$ Kubicek and S Tement "Work intensification and the work-home interface: The moderating effect of individual work-home segmentation strategies and organizational segmentation supplies" (2016) 15(2) Journal of Personnel Psychology 76.

${ }^{421}$ Philip Brown and Anthony Hesketh The Mismanagement of Talent (Oxford University Press, Oxford, 2004); Green, above at n 414.

${ }^{422}$ Korunka and Kubicek, above at $\mathrm{n} 413$, at 1 . 
performed. According to Rosa, "social acceleration" 423 is the increasing speed of social structural changes and the "speeding-up of intentional goal-directed processes of transport, communication, and production." ${ }^{24}$ Relatedly, the "acceleration of the pace of life involves the 'compression' of actions and experiences, with the aim of handling more actions within shorter timeframes." ${ }^{245}$ In responding to global economic pressures, Korunka and Kubicek argue that organisational change processes are executed at ever-shorter time intervals and:426

...management by objectives has resulted in a work organization based on individual goals, often without the necessary guidelines and resources to reach these goals.

Organisational restructuring has itself been shown to have negative effects on worker health and safety, operating to increase stress levels and rates of mental illness for those that lose their jobs, as well as those retaining them. ${ }^{427}$ The negative health effects on "survivors" stems both from the insecurity (especially where repeated restructuring is common) and the changes to their workloads resulting in intensification. ${ }^{428}$

\footnotetext{
${ }^{423}$ Hartmut Rosa Social acceleration: A new theory of modernity (Columbia University Press, Boston, 2015).

${ }^{424}$ Hartmut Rosa "Social acceleration: Ethical and political consequences of a desynchronized high-speed society (2003) 10(1) Constellations 3, at 6.

${ }^{425}$ Korunka and Kubicek, above at $\mathrm{n} 413$, at 2.

${ }^{426}$ Above.

${ }^{427}$ See Michael Quinlan "Organisational restructuring/downsizing, OHS regulation and worker health and wellbeing” (2007) 30(4) International Journal of Law and Psychiatry 385; N Dragano, P Verde and J Siegrist "Organisational downsizing and work stress: Testing synergistic health effects in employed men and women" (2005) 59 Journal of Epidemiology and Community Health 694; W Kim "Economic crisis, downsizing and 'layoff survivor's syndrome"” (2003) 33 Journal of Contemporary Asia 449; and M Quinlan and P Bohle "Overstretched and unreciprocated commitment: Reviewing research and policy debates on the OHS effects of downsizing and insecurity" (2009) 39(1) Int J Health Ser 1.

${ }^{428}$ See National Institute of Occupational Safety and Health The changing organisation of work and the safety and health of working people: Knowledge gaps and research directions (Cincinnati, US Department of Health and Human Services, 2002); See also Kim, above at n 427.
} 


\section{Digital monitoring and surveillance}

Employee monitoring and surveillance practices have also changed to reflect human resource management goals and new technologies, enabling and exacerbating the effects of intensified and hyper-connected work. For example, collaborative and project-based software allows for the "participation" of each employee to be tracked, and participant feedback and ratings to be sought constantly. ${ }^{429}$ Email, in addition to basic surveillance functions such as keyword monitoring and indicating if an employee is "online", also now typically integrates with personal calendars, diaries and email addresses, often automatically, allowing for real-time digital scheduling of work and non-work activities. Project and communication software also often links with employee Google, Facebook or YouTube accounts, allowing for "easier login", but also less separation between work and non-work digital activity.

As more organisations adopt workplace BYOD policies (bring your own device), in which employees bring their own choice of digital device, more businesses require employees to download applications specific to the organisation, or for the purposes of work. For example, application-based attendance tracking software is available, which obtains information about the location of the employee's device by GPS and integrates that data with payroll and scheduling software. ${ }^{430}$ Studies have shown greater use of such technologies at work is associated with greater stress-levels, ${ }^{431}$ and further that exposure to "technology stress" is associated with poorer health outcomes. ${ }^{432}$

\footnotetext{
${ }^{429}$ Such project management software includes Asana Project management $<$ www.asana.com $>$ and Monday.com $<$ www.monday.com $>$

${ }^{430}$ See for example "when I work" software $<$ www.wheniwork.com $>$ which allows for constant tracking of the employee's device and automatic integration with payroll software, as well as downloadable employee schedules of work. Other examples are: "People" by <www.ZOHO.com>, "My Attendance Tracker" at $<$ www.myattedancetracker.com $>$ or "TimeCamp" at $<$ www.timecamp.com $>$

${ }^{431}$ See the following book series which overviews the current research in this area: Pamela Perrewé, Jonathon Halbesleben and Chris Rose (eds) Book Series: Research in Occupational Stress and Well-being (Emerald Insights, e-book, 2010).

${ }^{432}$ Magdalena Stadin, Maria Nordin, Anders Brostrom, Linda Hanson Magnusson, and Hugo Westerlund "P091Information and communication technology stress at work and development of suboptimal self-rated health" (2016) 73 Occupational and Environmental Medicine A150.
} 
Technology-enabled monitoring and surveillance are often argued as a positive advance in worker stress monitoring and improving health and safety. The rise of "wearable-tech" allows for a wider range of personal and biometric data to be collected, allowing for health and safety related monitoring. For example, Smart Cap offers a range of caps, beanies and hard hats with integrated fatigue monitoring technology. These caps are described as utilising "state of the art brainwave technology to determine alertness" and offer real time monitoring. ${ }^{433}$ Low-cost stress monitoring devices are also available, including the Thync Relax Pro which monitors breathing, heart rate and muscle tension and then offers "neurostimulation" to help the wearer relax. This is also worn to aid sleep, sending 24-7 biometric data to its associated application. ${ }^{434}$ Another such device is BellaBeat Leaf, which is marketed as "smart jewellery" with a personal "wellness tracker" optimised for women. In addition to activity and sleep tracking, this device offers "fertility tracking," "stress monitoring" and "mindfulness training." 435

While wearable technologies may offer some health and safety benefits in certain circumstances, they are not without risk, ${ }^{436}$ enforcing notions that "stress" is an individual management problem, rather than a job design problem, and providing employers with large amounts of cheap, easily accessible employee health data, which is open to abuse and over which there is presently no regulation in New Zealand. ${ }^{437}$ The constant monitoring and digital presence of the employer may also result in longer periods of elevated stress levels, preventing the restoration of biological homeostasis (discussed further in the next section). This has the potential to exacerbate the other effects identified, as the boundaries

\footnotetext{
${ }^{433}$ More information on these products can be found on the Smart Cap Tech website:

$<$ http://www.smartcaptech.com/life-smart-cap/>

${ }^{434}$ See Thync.com website $<$ www.thync.com/ $>$

${ }^{435}$ See BellaBeat website $<$ www.bellabeat.com/ $>$

${ }^{436}$ See David Lyon (ed) Surveillance as social sorting: Privacy, risk and discrimination (Routledge, London, 2003).

${ }^{437}$ For a discussion of the application of New Zealand's privacy laws to employment see Gehan Gunasekara "Making a difference? The Privacy Act and employment relationship problems in New Zealand (2018) 28 NZ Universities Law Rev 25.
} 
between life inside and outside of work blur and the rights of employees to privacy, and "disconnection" are eroded. ${ }^{438}$

Constant digital real-time monitoring is also core to the business models of platform organisations like Uber and Uber Eats. ${ }^{439}$ Within these models a worker's every movement is managed by satellite and algorithm. Work allocation decisions are made on efficiency and cost to consumer, with the mental and physical needs of workers rarely factored in to the operation of algorithms. While some argue that platform-based appraisal systems are likely to provide workers with significant degrees of "adjustability, self-determination, task heterogeneity and intricacy," 440 others consider these mechanisms "facilitate low pay, social confinement and working unsocial and fluctuating hours, exploitation, sleep deficits and overtiredness." 441

\section{E Increasing flexibility and "precarious" work}

It is not only the excesses of work, either in hours or intensity, that have been shown to negatively impact on workers' health, but the unpredictability of work being available. Generally attributed to the same global economic factors that have resulted in work intensification and social acceleration, there is a growing international literature tracing the

\footnotetext{
${ }^{438}$ For a discussion of the right to reasonable hours and digital disconnection in New Zealand see Joss Opie "The right to reasonably limited working hours in the smartphone era" (2016) 41(3) NZJER 24.

${ }^{439}$ Gheorghe H Popescu, Irina Elana Petrescu and Oana Matilda Sabie "Algorithmic labour in the platform economy: Digital infrastructure, job quality and workplace surveillance" (2018) 13(3) Economics, Management and Financial Markets 74, at 74.

${ }^{440} \mathrm{Jim}$ Campbell, Suzanne Ross and Emily Thomson "Recession and recovery in Scotland: The impact of women's labour force participation beyond the headline statistics" (2017) 7(1) Journal of Gender Studies 123.

${ }^{441}$ See Douglas Hyers and Maria Kovacova "The economics of the online gig economy: Algorithms, hiring practices, and rights for platform workers (2018) 6(1) Psychological Issues in Human Resources Management 160; and Alex J Wood, Mark Graham, Vili Lehdonvirta and Isis Hjorth "Good gig, bad gig: Autonomy and algorithmic control in the global gig economy" (2019) 33(1) Work, Employment and Society 56.
} 
shifts towards "flexible' work", 442 the "gig economy",443 and the growing "precariat.",44 Alongside the growth of research into "flexible work" is research into the health effects for workers. ${ }^{445}$ Flexibility has multiple meanings, either referring to labour market flexibility or flexible work practices. Labour market flexibility is defined as "the ability [of an organisation] to adapt and respond to changes" including "the freedom to hire and fire", "wage flexibility" and internal and functional flexibility, which relates to the ability of firms to organise and reorganise labour quickly. ${ }^{446}$ Flexible work is a more recent concept, relating to an employee's ability to work more flexibly, including variations in hours, use of technology and working from home. Both forms of flexibility impact on worker health, although in different ways, with both being linked to the intensification of work and the rise in precarity.

"Precarity" is a term used in the literature to denote the state of being in precarious work with its associated social and psychological impacts. ${ }^{447}$ This is summarised succinctly as follows: $:^{448}$

Precarious work has made the availability as well as the quality of jobs more risky and uncertain. The consequences of this are not restricted to work and the workplace but also affect many nonwork domains, including individual health and well-being (e.g., owing to mental stress, poor physical health, and uncertainty about educational choices), family formation (delayed entry into marriage and having children), and the nature of social life more generally (community disintegration and declining social cohesion). Moreover, the anxiety, anger, anomie, and alienation

${ }^{442}$ Deirdre McCann Regulating Flexible Work (Oxford University Press, Oxford, 2008).

${ }^{443}$ Gerald Friedman "Workers without employers: Shadow corporations and the rise of the gig economy" (2014) Review of Keynesian Economics at 171, and Juliet Webster "Micro workers and the Gig Economy: Separate and Precarious (2016) 23 NLF 56.

${ }^{444}$ Guy Standing The Precariat: The Rise of the New Dangerous Class (Bloomsbury, London, 2011)

${ }^{445}$ See Elsa Underhill and Michael Quinlan "How precarious employment affects health and safety at work: The case of temporary agency workers" (2011) 66(3) Relations Industrielles 397; and L Artazcoz, J Benach, C Borell and I Cortes "Social inequalities in the impact of flexible employment on different domains of pstchosocial health" (2005) 59 J Epid Comm Health 761.

${ }^{446}$ Gerry Rodgers “Labour Market Flexibility and Decent Work” DESA UN Working Paper No 47 (July 2007).

${ }^{447}$ A recent review of the precarious work literature can be found in Arne Kalleberg and Steven Vallas (eds) Vol 31 Precarious Work (eBook series on the sociology of work) (Emerald Insights, e-book, 2017). ${ }^{448}$ Arne Kalleberg and Steven Vallas "Probing Precarious Work: Theory, Research, and Politics" in Kalleberg and Vallas, above, at 1. 
produced by the spread of uncertainty, insecurity, and inequality associated with precarious work have motivated workers to adopt protective strategies to defend themselves.

Standing refers to this as a "precariatized mind," which he explains as the effect of "not knowing how to allocate one's time and thus being under almost constant stress." ${ }^{449}$

Australian researchers have published papers on the increased health and safety impacts of flexible and precarious employment in Australia, ${ }^{450}$ and many of the same issues have been identified in New Zealand. ${ }^{451}$ In 2013 the New Zealand Council of Trade Unions (NZCTU) issued Under Pressure: A Detailed Report in to Insecure Work in New Zealand. ${ }^{452}$ It provided a picture of the growth in insecure work in New Zealand since the 1980s and highlighted the impacts of this on both worker health and wellbeing and also workplace health and safety. ${ }^{453}$ In addition to the large number of studies establishing the relationship between precarity and poor mental health for precarious workers, recent studies ${ }^{454}$ have also identified the "locked-in" consequence of a precarious labour market, whereby permanent workers are effectively trapped in undesirable jobs due to inability to find alternative permanent work or ongoing employment. ${ }^{455}$ For either the precarious or the locked-in worker the causal mechanism to poor health is stress discussed further below.

\footnotetext{
449 Guy Standing “The Precariat: Today's Transformative Class?” Great Transition Initiative (October 2018) <https://greattransition.org/publication/precariat-transformative-class $>$

${ }^{450}$ Underhill and Quinlan, above at 445.

${ }^{451}$ See Peter Scweder, Michael Quinlan, Philip Bohle, Felicity Lamm and Andy Huat Bin Ang "Injury rates and psychological wellbeing in temporary work: A study of seasonal workers in the New Zealand food processing industry" (2015) 40(2) NZJER 24; Margaret Wilson "Precarious work-New Zealand experience" (2014) 39(2) NZJER 22; and Katherine Ravenswood "Precarious work, vulnerable workers and the living wage" (2013) 38(2) NZJER 1.

${ }^{452}$ New Zealand Council of Trade Unions Under Pressure: A Detailed Report in to Insecure Work in New Zealand (NZCTU, Wellington, 2013).

${ }^{453}$ At $44-45$.

${ }^{454}$ Catarina Caniveta, Gunnar Aronsson, Claudia Bernhard-Oettel, Constanze Leineweber, Mahnaz Moghaddassia, Johanna Stengård, HugoWesterlund Per-Olof Östergrena "The negative effects on mental health of being in a non-desired occupation in an increasingly precarious labour market" (2017) 3 SSM Population Health 516.

${ }^{455}$ Above.
} 


\section{F Economic instability and vulnerability}

It is important to note that not all workers are affected equally. New Zealand's labour market remains highly segmented and some trends have a greater impact on particular groups of workers than others. Unsurprisingly, workers with the least bargaining power tend to fare the worst in stress-related illnesses associated with manner of engagement and wider social and economic disadvantage. ${ }^{456}$ Recent academic and media attention has focussed of the plight of "underemployed" and "working poor." 457 These groups are particularly important when considering stress-related conditions and causation. Even leaving aside the fact that such workers are often unwilling to bring claims for fear of losing their jobs or the practical difficulties of establishing rates of prior earnings, there are often significant difficulties in establishing which of potentially multiple employments are "the cause" of the person's stress. Further, it is often difficult to determine whether it is the unhealthy job or the economic circumstances of desperation forcing the person to perform the job, which are the primary cause of the individual's stress and ill health. Current occupational disease cover tests effectively exclude conditions that cannot be related to an identifiable task in one full-time job performed in one industry over a significant period of time.

As will be discussed further below, causal relationships, although able to be established, are rarely able to be isolated, and this has a particular impact on the most vulnerable workers. There is now a significant body of research exploring the impact of social and socio-economic status on health outcomes, with stress implicated in the development of

\footnotetext{
${ }^{456}$ See Artazcoz, Benach, Borell and Cortes, above at $\mathrm{n} 445$.

${ }^{457}$ Stuff (no author) "New Zealand's underemployed: Working, but not enough" (25 June 2018) Stuff $<$ https://www.stuff.co.nz/business/105001410/new-zealands-underemployed-working-but-notenough?utm_source=The+Bulletin\&utm_campaign=81430e5452->; Thomas Manch "New Zealand's 'working poor' and the push to understand how many are struggling" (16 May 2018) Stuff $<$ https://www.stuff.co.nz/national/103761074/new-zealands-working-poor-and-the-push-to-understandhow-many-are-struggling>; Tania Page "The working poor: In a job, but unable to make ends meet" (1 July 2018) TVNZ < https://www.tvnz.co.nz/one-news/new-zealand/working-poor-in-job-but-unable-make-endsmeet>
} 
many conditions. ${ }^{458}$ Poverty and stress have a psychological relationship as well as an economic one, with the "poverty amid plenty" phenomenon shown to add to the experience of stress. ${ }^{459}$

The famous Whitehall studies have also shed light on this relationship. ${ }^{460}$ The Whitehall health study began in 1967, and covered 18,000 British civil servants, following up with subjects over the subsequent years. The first of the Whitehall studies, or Whitehall I, found higher mortality rates due to all causes for men of lower employment grade. The study also revealed a higher mortality rate specifically due to coronary heart disease for men in the lower employment grades when compared to men in higher grades. ${ }^{461}$ As will be discussed further below, the causal connection was complex, with lower status associated with a higher prevalence of significant risk factors, such as obesity, smoking, reduced leisure time, and lower levels of physical activity, higher prevalence of underlying illness, higher blood pressure, and shorter height. What is particularly interesting, however, is that controlling for these risk factors accounted for no more than forty per cent of differences between civil service grades in cardiovascular disease mortality, and the lowest grade still had a relative risk of 2.1 for cardiovascular disease mortality compared to the highest grade. ${ }^{462}$

\footnotetext{
${ }^{458}$ See Salvatore Babones Social Inequality and Public Health (Policy Press, Bristol, 2009); Richard Wilkinson and M G Marmot Social Determinants of Health $\left(2^{\text {nd }}\right.$ ed, Oxford University Press, Oxford, 2006); Michael Marmot "Social justice, epidemiology and health inequalities (2017) 32(7) European Journal of Epidemiology 537; and Micheal Marmot and Ruth Bell "Social inequality in health: A proper concern of epidemiology" (2016) 26(4) Annals of Epidemiology 238.

${ }^{459}$ Robert Sapolsky Why Zebras Don't Get Ulcers (Freeman, New York, 2004), at 377.

${ }^{460}$ For an overview see M Marmot and A Feeney "Health and socioeconomic status" in G Fink (ed) Encyclopaedia of Stress (San Diego, Academic Press, 2000) at 313.

${ }^{461}$ M G Marmot, G Rose, M Shipley and P J Hamilton "Employment grade and coronary heart disease in British civil servants" (1978) 32(4) J Epidemiol Community Health 244.

${ }^{462}$ Above. An online archive for all the Whitehall Study related papers is maintained by the London School of Hygiene and Tropical Medicine <https://www.lshtm.ac.uk/research/library-archivesservice/archives/whitehall-study-archive-collection>
} 
Twenty years later, the Whitehall II study documented a similar gradient in morbidity in women as well as men. ${ }^{463}$ The Whitehall studies revealed this social gradient for a range of different conditions: heart disease, some cancers, chronic lung disease, gastrointestinal disease, depression, suicide, sickness absence, back pain and general feelings of illhealth. ${ }^{464}$ These organisational phenomena can also be seen in wider society. In societies with greater income inequality both the poor and the rich have poorer health outcomes. ${ }^{465}$ "Income inequality" predicts poor health outcomes better than absolute income ${ }^{466}$ and is a "really strong predictor" of mortality rates among working men. ${ }^{467}$ New Zealand's now famous longitudinal Dunedin Study has also contributed to the understanding of socioeconomic class, work stress, and health outcomes. ${ }^{468}$ Studies like Whitehall, and the Dunedin Study highlight the complexities of stress-related illness and the complex relationships of causation that may exist.

The trends identified are not uniformly felt and depend on the industry worked in. As discussed in the previous chapters, risk exposure is specific to the type of job, and the employment and management practices in a given industry. There are also cultural differences in people's responses to such practices and perceptions of ill health, as discussed in Chapter Six.

\footnotetext{
${ }^{463}$ See M G Marmot, S Stansfield, C Patel, F North, J Head, I White, E Brunner, A Feeney, G Davey-Smith "Health inequalities among British civil servants: The Whitehall II Study" (1991) 337(8754) Epidemiology 1387.

${ }^{464}$ Above.

${ }^{465}$ Sapolsky, above at n 459, at 378 .

${ }^{466}$ Above, at 375.

${ }^{467}$ Above.

${ }^{468}$ See Maria Melchior, Avshalom Caspi, Barry Milne, Andrea Danese, Richie Poulton and Terriee Moffitt "Work stress precipitates depression and anxiety in young, working men and women" (2007) 37 Psych Med 1119.
} 


\section{The Parallel Rise of Stress-Related Illness Research}

The growth of research in to stressful work has been paralleled by the growth of research in to work-stress-related illnesses. ${ }^{469}$ Stress has been defined in many ways, and, of course, contains both a subjective, social and cultural component to its definition. A review of the work-stress and illness research from the 1960s identified departing disciplinary conceptualisations and a divergence in different contexts e.g. management, health and safety, organisational wellbeing, public health or medicine. ${ }^{470}$ While this is important to be aware of, and is discussed in greater detail in the following chapter, this chapter concerns a brief overview of current medical thinking on stress and its causal connection to disease.

\section{A What is stress?}

Starting with the bio-medical conception, stress is not itself a disease, but an adaptive response of the body to a demand. In contrast to how it is frequently described in human resources literature, "stress is not a subjective feeling. It is a measurable set of physiological events in the body." 471 The word "stress" originated in the field of physics, referring to "pressure or tension exerted on a material object." 472 The term was likely introduced in to medicine by the physiologist Walter Cannon in the $1920 \mathrm{~s},{ }^{473}$ but the start of stress research in the biological sciences is credited to the "godfather of stress research", Hans Selye. ${ }^{474}$ Selye was attempting to prove the effect of a particular substance on rats. As a result of being dropped and frequently chased with a broom, both groups of rodents (treated and control) showed increased stress-related diseases for which he could find no other cause than his particularly traumatic rodent handling techniques. ${ }^{475}$

\footnotetext{
${ }^{469}$ Väänänen, Murray and Kuokkanen, above at n 395, at 126.

${ }^{470}$ Above, at 127.

${ }^{471}$ Nicole Baumann and Jean-Claude Turpin "Neurochemistry of Stress. An Overview” (2010) 35 Neurochem Res 1875, at 1876.

472 "Stress" Oxford English Dictionary (1 May 2019) <https://en.oxforddictionaries.com/definition/stress>

${ }^{473}$ Walter Cannon "Stress and Strains of homeostasis" (1935) 189 Am J Med 1.

${ }^{474}$ Hans Selye "The general adaptation syndrome and the diseases of adaptation" (1946) 6 J Clin Endicronal Metab 117.

${ }^{475}$ Sapolsky, above at 459 , at 8 .
} 
Selye formalised the concept with two key ideas. First, "the body has a surprisingly similar set of responses...to a broad array of stressors" which he called the general adaptation syndrome, but which is now often called the stress-response. The second idea was that "if stressors go on for too long, they make you sick." ${ }^{476}$ Selye's research was developed and significantly expanded on, benefiting from advances in medical technology, including the invention of fMRI machines. Stress became linked to the concept of homeostasis, advanced by people such as Peter Stirling and Joseph Eyer. ${ }^{477}$ Stress was defined as acute threats to the homeostasis of an organism, ${ }^{478}$ be they real (physical) or perceived (psychological), and whether posed by events in the outside world or from within. This evokes an adaptive response which it is argued serves to defend the stability of the internal environment and to assure the survival of the organism. ${ }^{479}$ This ability to defend homeostasis (that is, to maintain stability) through change has been referred to as allostasis. ${ }^{480}$

\section{B The human stress response}

To summarise, the stress response begins in the brain, with the amygdala, the area of the brain that contributes to emotional processing, interpreting a person's experiences. When someone experiences a stressful event the amygdala sends a distress signal to the hypothalamus, communicating with the rest of the body through the autonomic nervous

\footnotetext{
${ }^{476}$ Above, at 8 .

${ }^{477}$ Discussion of the development of this model can be found in Mathieu Arminjon "Birth of the allostatic model: From Cannon's biocracy to critical physiology (2016) 49(2) J Hist Biol 397.

${ }^{478}$ Hans Selye Stress (Acta Medical Publisher, Quebec, 1950); GP Chrousos and PW Gold "The concepts of stress and stress system disorders: overview of physical and behavioral homeostasis" (1992) 267 JAMA 124; GP Chrousos, DL Loriaux, PW Gold "The concept of stress and its historical development" (1988) 245 Adv Exp Med Biol 3.

${ }^{479}$ A Ericsson, EA Mayer, CB Saper, PE Sawchenko and HY Li "Circuits and mechanisms governing hypothalamic responses to stress: A tale of two paradigms" in A Ericsson, EA Mayer, CB Saper (eds) The Biological Basis for Mind Body Interactions (Vol 6, 122 ed, Elsevier Science, Amsterdam, 2000) at 59-75. ${ }^{480} \mathrm{P}$ Sterling, J Eyer and S Fisher (eds) Handbook of life stress, cognition and health (John Wiley, New York, 1988), at 629-649.
} 
system. ${ }^{481}$ The nervous system controls involuntary body functions such as breathing, blood pressure, heartbeat, and the dilation or constriction of key blood vessels and the small airways in the lungs. It is divided in to two parts, the sympathetic and parasympathetic nervous system. The sympathetic nervous system operates in response to (or what our body perceives to be) an emergency, the often called 'fight or flight response' releasing adrenaline and the related hormone noradrenaline. ${ }^{482}$ As Sapolsky explains: ${ }^{483}$

The autonomic system works in opposition: sympathetic and parasympathetic projections from the brain course there way out to a particular organ where, when activated, they bring about opposite results. The sympathetic system speeds up the heart, the parasympathetic system slows it down. The sympathetic system diverts blood flow to your muscles; the parasympathetic does the opposite.

Put simply, this can be understood as: ${ }^{484}$

[T] he sympathetic nervous system functions like a gas pedal in a car. It triggers the fightor-flight response, providing the body with a burst of energy so that it can respond to perceived dangers. The parasympathetic nervous system acts like a brake. It promotes the "rest and digest" response that calms the body down after the danger has passed.

As adrenaline circulates through the body, it brings on the physiological changes which we typically experience when stressed. The heart beats faster, pushing blood to the muscles, heart, and other vital organs. Pulse rate and blood pressure go up. The person undergoing these changes also starts to breathe more rapidly and small airways in the lungs open wide so lungs can take in as much oxygen as possible. Extra oxygen is sent to the brain, increasing alertness. Sight, hearing, and other senses become sharper. Meanwhile, adrenaline triggers the release of blood sugar and fats from temporary storage sites in the body. These nutrients flood into the bloodstream, supplying energy to all parts of the body. ${ }^{485}$

\footnotetext{
${ }^{481}$ Harvard Medical School "Understanding the stress response: Chronic activation of this survival mechanism impairs health" (18 March 2016) Harvard Health Publishing

$<$ https://www.health.harvard.edu/staying-healthy/understanding-the-stress-response $>$

${ }^{482}$ Sapolsky, above at $\mathrm{n} 459$, at 22.

${ }^{483}$ Above, at 11.

${ }^{484}$ Harvard Medical School, above at n 481481.

${ }^{485}$ Above.
} 


\section{Stress and its connection to disease}

In the healthy individual, the physiological response systems are rapidly turned on and off, limiting the exposure to the potentially harmful effects of the stress response. ${ }^{486}$ However, when the stress response is activated too often or for too long it starts to have negative consequences. This can "exacerbate existing disease processes, or predispose the individual to acquire new diseases" described as becoming "maladaptive". ${ }^{487}$ Long-term effects of an organism's accommodation to certain types of stress is referred to as allostatic load, ${ }^{488}$ meaning the "wear and tear" resulting from "chronic overactivity or underactivity of physiological stress response systems." ${ }^{489}$

Stress is not unique to humans, and the human stress response is very like that in other primates. ${ }^{490}$ Many papers suggest that there is simply a mismatch between how our bodies evolved to respond to stressors and the present realities of working life filled with performance reviews, output targets and increasing workloads facilitated by new technologies. Put better by Robert Sapolsky, for other species "the most upsetting things in life are acute physical crises" such as being chased by a lion. ${ }^{491}$ These events require "immediate physiological adaptations" if you are going to survive and the body's responses are brilliantly adapted to handling such emergencies. ${ }^{492}$ Sapolsky further explains that: ${ }^{493}$

...we humans live well enough and long enough, and are smart enough, to generate all sorts of stressful events purely in our heads.... Viewed from the perspective of the evolution of the animal kingdom, sustained psychological stress is a recent invention, mostly limited to humans and other social primates. We can experience wildly strong emotions (provoking our bodies into an accompanying uproar) linked to mere thoughts.

\footnotetext{
${ }^{486}$ Sterling, Eyer and Fisher, above, at n 480.

${ }^{487}$ E A Mayer "The neurobiology of stress and gastrointestinal disease" (2000) 46(6) Gut 861.

488 B McEwen "Protective and damaging effects of stress mediators" (1998) 338 N Engl J Med 171.

${ }^{489}$ Mayer, above at $\mathrm{n} 487$.

490 Sapolsky, above at n 459.

491 At 4.

492 At 4.

493 At 5.
} 
Chronic over-activation of the human stress response has been linked to a wide variety of diseases. ${ }^{494}$ This chapter focuses on three key areas of cardiovascular disease, depression and musculoskeletal disorders which cannot be easily attributed to an acute physical "accident".

\section{$V$ Stress and Cardiovascular Diseases}

As in each of the case studies used in this chapter, there is debate about the precise causal mechanisms and extent that work stress contributes to any given individual's likelihood of developing cardiovascular disease. This complexity in causal relationship is, in part, why these conditions have been selected for analysis in the thesis. The asserted causal relationship between the stress response, summarised above, and cardiovascular disease is explained by the Harvard Medical School's public health guidance: ${ }^{495}$

Chronic low-level stress keeps the HPA axis activated...Persistent epinephrine [the term used for adrenaline in some countries] surges can damage blood vessels and arteries, increasing blood pressure and raising risk of heart attacks or strokes. Elevated cortisol levels create physiological changes that help to replenish the body's energy stores that are depleted during the stress response. But they inadvertently contribute to the build-up of fat tissue and to weight gain. For example, cortisol increases appetite, so that people will want to eat more to obtain extra energy. It also increases storage of unused nutrients as fat.

Explained more simply, stress results in elevation of blood pressure. Blood vessels regulate blood flow and ensure adequate levels of oxygen and nutrients around the body. Where blood pressure is chronically elevated the blood vessels have to work harder to regulate blood flow. To do this the blood vessels build a thick layer of muscle around them, becoming more rigid and more resistant to the blood flow. ${ }^{496}$ This means that blood flow is now returning to the heart with more force and having a greater impact on the heart

\footnotetext{
$\overline{{ }^{494} \text { See Kezhong Zhang "Environmental stressor, stress response, and disease" (2018) 3(1) Environmental }}$ Disease 1.

${ }^{495}$ Harvard Medical School, above, at n 481481.

${ }^{496}$ Sapolsky, above, at n 459, at 42. See also Satish Mittal Coronary Heart Disease in Clinical Practice (Springer, London, 2005) and Regis A de Silva Heart Disease (biographies of disease series)( ABC-CLIO, e-book, 2013).
} 
muscles, which over time will also thicken with more muscle. This is referred to as "left ventricular hypertrophy" which means increasing mass in the left ventricle of the heart and is "the single best predictor of cardiac risk". ${ }^{497}$ This makes the heart lop-sided, which increases the risk of an irregular heartbeat. ${ }^{498}$

Blood vessels descend in size, down in to the tiny capillaries, with the vessels forming branches. The increased pressure of the blood forced through the vessels increases the damage to these branches, causing tears and craters in the vessel lining. This triggers an inflammatory response and also accumulations of fatty cells, called foam cells, in these sites. ${ }^{499}$ In addition to this, during activation of the stress response, the central nervous system makes the blood more viscous. "Epinephrine makes circulating platelets... more likely to clump together, and these clumped platelets can get gummed up in theses aggregates as well." 500 These are referred to as "osclerotic plaques."501 The causal relationship between stress and cardiovascular diseases is that "stress promotes plaque formation by increasing the odds of blood vessels being damaged and inflamed, and by increasing the likelihood that circulating ...platelets, fat, cholesterol and so on... sticks to those inflamed injury sites." 502

\section{A Stress and heart attack}

Stress can also trigger acute events. Where an individual has built up plaques within the vessels, a stress induced increase in blood pressure increases the risk of these plaques

\footnotetext{
${ }^{497}$ See Beverly Lorell and Blasé Carabello "Left ventricular hypertrophy: pathogenesis, detection and prognosis" (2000) 102 Circulation 470.

${ }^{498}$ See P Hjemdahl, A Steptoe, A Rosengren (eds) Stress and Cardiovascular Disease (Springer, London, 2011).

${ }^{499}$ Goran Hansson "Inflammation, atherosclerosis, and coronary artery disease" (2005) 352 N Eng J Med 1685 .

${ }^{500}$ Sapolsky, above at 459 , at 43.

${ }^{501}$ See Peter W F Wilson Atlas of Atherosclerosis: Risk factors and treatment (Springer Science and Business Media, ebook, 2013), at 32-34.

${ }^{502}$ Sapolsky, above at n 459, at 43. See also Hjemdahl, Steptoe and Rosengren, above at n 498.
} 
tearing free or rupturing the vessel, causing a "thrombus" and clogging the vessel. ${ }^{503}$ If the clog occurs in a coronary artery it is called a "myocardial infarct" or heart attack. If the clog occurs in the brain it causes a stroke. Stress is also related to "myocardial ischemia," which is a condition that occurs when the arteries feeding the heart become so clogged that the heart becomes deprived of blood flow, and thus oxygen and glucose. ${ }^{504}$ When a person with myocardial ischemia encounters something stressful their sympathetic nervous system speeds up the heart, and rather than the blood vessels dilating (as in a healthy individual) they "vasoconstrict," shutting down the clogged vessels even more and depriving the heart of nutrients causing "angina pectoris" chest pain. ${ }^{505}$ "Once the cardiovascular system is damaged it appears immensely more sensitive to acute stressors, whether physical or psychological." 506

\section{B Work-stress and cardiovascular diseases}

There is research looking specifically at work-stress and the development of cardiovascular diseases. Repeated activation of the autonomic nervous system is "characterised by lowered heart rate variability, which has been associated with work stress among men in cross-sectional studies." ${ }^{507}$ Low job control has been found to predict coronary disease incidence. ${ }^{508}$ Research has shown "[g]reater reports of work stress were associated with a higher risk of cardiovascular disease" and among younger workers "there was a clear doseresponse association between greater reports of work stress and higher risks of incident

\footnotetext{
${ }^{503}$ See Wilson, above at $\mathrm{n}$ 501, and Mitall and de Silva, above at $\mathrm{n} 496$.

${ }^{504}$ David Crossman "The pathophysiology of myocardial ischaemia" (2004) 90(5) Heart 576.

${ }^{505}$ Sapolsky, above at n 459, at 47.

${ }^{506}$ Above, at 48.

${ }^{507}$ Tarani Chandola, Annie Britton, Eric Brunner, Harry Hemingway, Marek Malik, Meena Kumari, Ellena Badrick, Mika Kivimaki, and Michael Marmot "Work stress and coronary heart disease: What are the mechanisms?" (2008) 29 European Heart Journal 640, at 640; T Vrijkotte, L van Doornen, E de Geus "Effects of work stress on ambulatory blood pressure, heart rate, and heart rate variability" (2000) 35 Hypertension 880; and H Hemingway, M Shipley, E Brunner, A Britton, M Malik and M Marmot "Does autonomic function link social position to coronary risk? The Whitehall II study" (2005) 111 Circulation 3071.

${ }^{508}$ H Bosma, M Marmot, H Hemingway, A Nicholson, E Brunner, S Stansfeld "Low job control and risk of coronary heart disease in the Whitehall II (prospective cohort) study" (1997) 314 BMJ 558.
} 
[cardiovascular] events. ${ }^{" 509}$ One of the largest international studies, the INTERHEART study, showed that psychosocial factors were associated with acute myocardial infarction in 15,000 cases and controls from 52 countries in Europe, America, Africa, Asia and Australia. ${ }^{510}$ This study showed that "exposure to psychosocial factors added to risk even after taking into account the combined exposure to smoking, diabetes, hypertension, ApoB/ApoA1 ratio and obesity" and "the odds ratio increased from 68.5 to 182.9 compared with those free from all these risk factors." ${ }^{\text {511 }}$ The British Whitehall II study, discussed above, is also a significant study linking psychosocial factors and cardiovascular health. ${ }^{512}$

The picture is, however, not quite that simple, as work stress is not the only factor required to develop cardiovascular disease, nor is it required in every case. As discussed further in the next chapter, work stress is neither a "necessary" nor "sufficient" cause on its own. Despite being linked to work stress, cardiovascular diseases are primarily thought of as diseases of diet and exercise, with some genetic component to them, and these are likely significant if not dominant contributing causal factors. The factors are also potentially interrelated. Research links chronic stress to hypertension and atherosclerosis, which typically precede cardiovascular events. Accumulation of work stress is associated with higher risks of metabolic syndrome, and incident obesity, both linked to cardiovascular disease. ${ }^{513}$ Stress is linked to poor sleeping patterns, and poor sleep is linked with

\footnotetext{
${ }^{509}$ S Kunz-Ebrecht, C Kirschbaum, A Steptoe "Work stress, socioeconomic status and neuroendocrine activation over the working day" (2004) 58 Soc Sci Med 1523, at 642.

${ }^{510} \mathrm{~S}$ Yusuf, S Hawken and S Ounpuu "Effect of potentially modifiable risk factors associated with myocardial infarction in 52 countries (the INTERHEART study): case-control study" (2004) 9438 Lancet 937, at 364 .

${ }^{511}$ M Kivimäki, A Singh-Manoux A GD Batty, M Virtanen, JE Ferrie and J Vahtera "Psychosocial factors at work: The epidemiological perspective" in P Hjemdahl, A Steptoe, A Rosengren, above, at n 498.

${ }^{512}$ MG Marmot, G Davey Smith and S Stansfeld "Health inequalities among British civil servants: the Whitehall II study" (1991) 8754 Lancet 3371387.

513 Tarani Chandola, above, at n 507.
} 
hypertension, ${ }^{514}$ type-2 diabetes, ${ }^{515}$ increased body mass index,${ }^{516}$ alterations in blood lipids, ${ }^{517}$ and inflammatory markers ${ }^{518}$ - all factors known to increase the risk of cardiovascular disease. ${ }^{519}$ Greater reports of work stress were also associated with poorer health behaviours in terms of eating less fruit and vegetables and less physical activity. ${ }^{520}$ There are also other interrelated factors linked to lower socio-economic status.

\section{Stress and its Connection to Depression}

Work-stress has also been associated with the development of depression and anxiety. Anxiety and depression are both significant illnesses, and potentially connected to each other, and also the subsequent development of cardiovascular disease and back pain. ${ }^{521}$ Mental illness is a significant and growing cause of incapacity worldwide, and in New Zealand, with suicide being the second leading cause of death for non-Māori males and the third leading cause of death for Māori males. ${ }^{522}$ Internationally, depression is expected to

\footnotetext{
514 JE Gangwisch, SB Heymsfield and B Boden-Albala "Short sleep duration as a risk factor for hypertension: Analyses of the first National Health and Nutrition Examination Survey" (2006) 47(5) Hypertension 833.

${ }^{515}$ JE Gangwisch, SB Heymsfield and B Boden-Albala "Sleep duration as a risk factor for diabetes incidence in a large U.S. sample" (2007) 30(12) Sleep 1667; HK Yaggi, AB Araujo, JB McKinlay "Sleep duration as a risk factor for the development of type 2 diabetes" (2006) 29(3) Diabetes Care 657. ${ }^{516}$ S Stranges, FP Cappuccio and NB Kandala "Cross-sectional versus prospective associations of sleep duration with changes in relative weight and body fat distribution: the Whitehall II Study" (2008) 167(3) Am J Epidemiol 321.

${ }^{517}$ AN Vgontzas, EO Bixler, GP Chrousos "Sleep apnea is a manifestation of the metabolic syndrome" (2005) 9 Sleep Med Rev 211.

518 AN Vgontzas, E Zoumakis and EO Bixler "Adverse effects of modest sleep restriction on sleepiness, performance, and inflammatory cytokines” (2004) 89(5) J Clin Endocrinol Metab 2119.

${ }^{519}$ For greater discussion see Torbjörn Åkerstedt and Aleksander Perski "Sleep, Stress, and Heart Disease" in P Hjemdahl, A Steptoe, A Rosengren, above, at 498.

${ }^{520}$ Tarani Chandola, above, at n 507.

${ }^{521}$ Richard Holtad, David Phillips, Karen Jameson, Cyrus Cooper, Elaine Dennisona and Robert Pevelerc "The relationship between depression, anxiety and cardiovascular disease: Findings from the Hertfordshire Cohort Study" (2013) 150(1) Journal of Affective Disorders 84.

${ }^{522}$ Statistics available on the New Zealand Ministry of Health website $<$ http://www.health.govt.nz/ourwork/populations/maori-health/tatau-kahukura-maori-health-statistics/nga-mana-hauora-tutohu-healthstatus-indicators/major-causes-death>
} 
become the second leading cause of worldwide disability by $2030 .{ }^{523}$ Recognizing the significance of the issue, the Government established the Government Inquiry in to Mental Health and Addiction, which highlighted the potential social and economic impacts of poor mental health..$^{524}$

While rare and exotic diseases receive the most attention in the discussion of occupational health, depression and anxiety are the most likely "bread and butter" work-related illness that any modern workers' compensation scheme will need to deal with. Depression, like any complex and multifactorial illness, has questions of definition and diagnosis. As set out further below, definitions of depression are also culturally and socially informed. Yet, a useful starting point is the Diagnostic and Statistical Manual of Mental Disorders (DSM5), which defines depression as follows: ${ }^{525}$

It is characterized by discrete episodes of at least 2 weeks' duration (although most episodes last considerably longer) involving clear-cut changes in affect, cognition, and neurovegetative functions and inter-episode remissions. A diagnosis based on a single episode is possible, although the disorder is a recurrent one in the majority of cases.

Sapolosky also defines it eloquently as "a genetic/neurochemical disorder requiring a strong environmental trigger whose characteristic manifestation is an inability to appreciate sunsets." ${ }^{526}$ The precise causal mechanisms involved are complex and not completely understood, but the prevailing thinking is some combination of the direct neurotoxic effects of cortisol on the brain, down-regulation of the glucocorticoid receptor, which impairs emotional control (affect regulation), an increase in pro-inflammatory cytokine levels and the leaking of non-pathogenic commensal bacteria from the gut in to peripheral circulation. ${ }^{527}$ Depression is a complex condition likely involving the interplay of genetics, neurochemistry, psychological traits, physical and social environments and the interactions

\footnotetext{
${ }_{523}$ Mathers and Loncar, above at $\mathrm{n} 384$.

${ }^{524}$ Government Inquiry in to Mental Health and Addiction, above at n 295.

${ }^{525}$ For recent discussion of the criteria see Julio Tolentino and Sergio Schmidt "DSM-5 criteria and depression severity: Implications for clinical practice" (2018) 9 Front Psychology 450.

${ }^{526}$ Sapolsky, above, at $\mathrm{n} 459$, at 272.

${ }^{527}$ M J Rantala, S Luoto, I Krams and H Karlsson "Depression subtyping based on evolutionary psychiatry: Proximate mechanisms and ultimate functions” (2018) 69 Brain Behav Immun 603.
} 
between them. In response to such complex interrelationships, many in health sciences research have adopted the "bio-psycho-social" framework. ${ }^{528}$ The framework is basically just a recognition that diseases have a biological (bio), psychological (psycho) and social or environmental (social) component to them.

Given the global rise of depression as a cause of incapacity, the research in to depression and its causes have substantially increased, with the neuroscience of depression advancing particularly quickly. ${ }^{529}$ Neuroscientists have suggested heightened activity in the amygdala, which plays a significant role in fear and anxiety to be associated with depression. Cattaneo and Riva provide for a more detailed treatment of the neurobiology of depression and the particular role of glucocorticoid signalling and depression. ${ }^{530}$ Research into the impact of glucocorticoids on memory ${ }^{531}$ is also contributing to the understanding of depression, with the elevated glucocorticoid levels observed in depression potentially explaining problems with hippocampal-dependent memory. ${ }^{532}$ Put simply, the lack of motivation observed in the depressed person may reflect memory problems or the "anhedonic inability to respond to the rewards of remembering something in a task." ${ }^{533}$ It has also been observed that the hippocampus is smaller than average in many people with depression, offering some clue in to causality. ${ }^{534}$ Advances in technology allow for a much more sophisticated understanding of the mechanisms of disease and the relationship

${ }^{528}$ See Shane Mc Inerney "Introducing the biopsychosocial model for good medicine and good doctors" (2002) 1537 BMJ 324.

${ }^{529}$ M O'Connor, L Litrell, C Fort, R Lane "Functional neuroanatomy of grief: An MRI study" (2003) 160 American Journal of Psychiatry 1946; N Eisenberger, M Leiberman and K Williams "Does rejection hurt? An fMRI study of social inclusion" (2003) 320 Science 290; R Davidson, D Jackson and N Kalnin "Emotion, plasticity, context, and regulation: Perspectives from affective neuroscience" (2000) 126 Psychological Bulletin 890; and W Drevets "Neuroimaging and neuropathological studies of depression: Implications for the cognitive-emotional features of mood disorders" (2001) 11 Current Opinion in Neurobiology 240.

${ }^{530}$ A Cattaneo and M Riva "Stress induced mechanisms and mental illness: A role for glucocorticoid signalling" (2016) 160 Journal of Steroid Biochemistry and Molecular Biology 169.

${ }^{531}$ Sapolsky, above at $\mathrm{n} 459$.

532 Above.

${ }^{533}$ Above, at 276.

${ }^{534}$ At 276. 
between genetics and environment. ${ }^{535}$ Recent research out of the University of Auckland suggests that depression also comes in multiple forms ${ }^{536}$ This study is of particular interest as it suggests work-stress related depression may be an observably different illness to other forms, offering the potential to address questions of causation.

\section{A Stressful environments and depression}

While depression is considered a "biological process" that does not mean it is not triggered by the environment outside the person's body. There are several causal models of depression in the literature. One such model considers depression the result of repeated exposure to unpredictable and uncontrollable adverse events as a major cause of depression. Seligman is often associated with some of the early experimental work on this model of depression. ${ }^{537}$ Seligman and colleagues placed animals in "conditions of maximum uncertainty." ${ }^{538}$ For example, shocking the animal in the foot at random times or for varied lengths in a totally unpredictable fashion. "The animals soon learned that nothing they did made a difference. After trying hard at first to control the aversive stimulus, the animals would end up cowering in their cages, avoiding human contact, appearing to lose all interest in their surroundings." ${ }^{539}$

Willner has developed a model that focuses on chronic stressful situations that provoke a loss of interest and pleasure. Rather than introducing a brief series of highly aversive events, such as shock or loud bursts of unpredictable noise, ${ }^{540}$ Willner and his colleagues began testing the effects of milder stressors that occur over an extended period of time. To

\footnotetext{
${ }^{535}$ See T Frodl, MSyzf, A Carballedo, M Gill and L Booij "Integrated functional imaging and genetics in depression and anxiety" (2015) 3 European Psychiatry 119.

${ }^{536}$ See Rantala, above at n 527.

${ }^{537}$ See M Seligman Helplessness: On depression, development and death (Freeman, San Francisco, 1975); and M Seligman, L Abramson, A Semmel and C von Baeyer "Depressive attributional style" (1979) 88 Jrnl Abnormal Psych 242.

${ }^{538}$ Above.

${ }^{539}$ Above.

${ }^{540}$ Alex Zautra Emotions, Stress, and Health (Oxford University Press, Oxford, 2003).
} 
produce what they referred to as chronic mild stress, the researchers arranged a variety of unpleasant experiences for each of their animals. The studies concluded that chronic mild stressors have lasting effects on the animals' interests in pleasurable experiences. They become impervious to such pleasures as sipping on sugar water. Zuatra explains that: ${ }^{541}$

Scores of studies provide additional evidence to support the idea that these chronically stressed animals lose much of their interest in their surroundings. They engage in less sexual activity, are less likely to explore open fields, and even show less motivation to pursue self-stimulation of "pleasure" centres in the brain. The effects last for months. Interestingly enough, these patterns are reversible by giving the animals a regimen of anti-depressive medications equivalent to what a person might take for major depression.

Humans are of course different in many ways. We have a greater ability to think about and understand what is happening to us. Of course, we also have a much greater ability to imagine stressors in future, which, as set out above, can trigger much the same physiological response. The models above have been applied to human work, with Zautra concluding: "[s]ocial changes in the nature of work experience portend an ever-increasing degree of uncertainty over some fundamental aspect of the work experience." 542 This suggests that a "consequence of fostering uncertainty over such basic aspects as job security may increase performance initially but also increase the risk of illness and injury by disturbing emotional awareness and regulation." 543

\section{B Three organizational psychology conceptual models}

In addition to neurobiological enquiries, organisational/occupational health psychology has also seen several decades of work-stress-depression research. There are three key conceptual models used in the occupational health research: the demand-control model, the effort-reward imbalance model and the work-family conflict model. The demand-control model, originally put forward by Karasek in 1979, posits that the negative health outcomes, such as fatigue, depression, and other physical illnesses, result from the situations in which

${ }^{541}$ Zautra, above, at 224.

542 Above, at 321.

${ }^{543}$ Above, at 322. 
control over one's work is low and the psychological demands imposed by work are high. ${ }^{544}$ The effort-reward imbalance model focuses on the experience of a lack of reciprocity, meaning high costs and low rewards that generate negative emotions in exposed people. 545 "Feelings of not being appreciated in an adequate way or of being treated unfairly and disappointments resulting from inappropriate rewards are paralleled by sustained strain reactions in the autonomic nervous system." 546 Effort-reward imbalance has been found to be associated with depressive symptoms. ${ }^{547}$ The work to family conflict model considers conflict occurs when efforts to fulfil the demands of the employee role interfere with the ability to fulfil the demands of the roles as a spouse, parent or care provider. This becomes an obstacle to successfully meeting work-related demands and responsibilities, thereby "undermining a person's ability to construct and maintain a positive work-related self-image". ${ }^{548}$ Epidemiological studies have found that job strain or work stress and work-family conflicts are strongly associated with major depression. ${ }^{549}$

\footnotetext{
${ }^{544}$ RA Karasek "Job demands, job decision latitude, and mental strain: implications for job redesign" (1979) 24 Admin Sci Q 285. See also JianLi Wang, Elizabeth Smailes, Jitender Sareen, Norbert Schmitz, Gordon Fick and Scott Patten "Three job-related stress models and depression: a population-based study" (2012) 47 Soc Psychiatry Psychiatr Epidemiol 185.

${ }^{545}$ J Siegrist, D Starke, T Chandola, I Godin, M Marmot, I Niedhammer and R Peter "The measurement of effort-reward imbalance at work: European comparisons" (2004) 58(8) Soc Sci Med 1483.

${ }^{546}$ See Wang, Smailes, Sareen, Schmitz, Fick and Patten, above at n ; See also Siegrist, Starke, Chandola, Godin, Marmot, Niedhammer, Peter, above at n 546.

${ }^{547}$ N Wege, N Dragano, R Erbel, KH Jockel, S Moebus, A Stang and J Siegrist "When does work stress hurt? Testing the interaction with socioeconomic position in the Heinz Nixdorf Recall Study" (2008) 62(4) J Epidemiol Commun Health 338; N Dragano, Y He, S Moebus, KH Jo"ckel, E Erbel and J Siegrist "Heinz Nixdorf Recall Study Two models of job stress and depressive symptoms. Results from a population-based study” (2008) 43(1) Soc Psychiatry Psychiatr Epidemiol 72; I Niedhammer, JF Chastang, S David, L Barouhiel and G Barrandon "Psychosocial work environment and mental health: Jobstrain and effortreward imbalance models in a context of major organizational changes" (2006) 12(2) Int J Occup Environ Health 111.

${ }^{548}$ T Chandola T, P Martikainen, M Bartley, E Lahelma, M Marmot, S Michikazu, A Nasermoaddeli, S Kagamimori "Does conflict between home and work explain the effect of multiple roles on mental health? A comparative study of Finland, Japan, and the UK" (2004) 33(4) Int J Epidemiol 884; Wang, Smailes, Sareen, Schmitz, Fick and Patten, above at n 544; See also Siegrist, Starke, Chandola, Godin, Marmot, Niedhammer, Peter, above at n 545, at 186

549 JL Wang "Perceived work stress and major depressive episode(s) in a population of employed Canadians over 18 years old" (2004) 192(2) J Nerv Ment Dis 160; JL Wang "Work stress as a risk factor for major depressive episode(s)" (2005) 35(6) Psychol Med 865; JL Wang, TO Affifi and B Cox B "The relationship between work-home imbalance and mental disorders: findings from the US. National
} 


\section{The interrelated role of genetics and environment}

While characterised as a "stress-related illness" with a strong environmental component, there is considerable variability in the extent to which a working environment will trigger the development of disease in any given individual. Some of this variability is attributed to the differing availability of support and resources and individual personality trait differences. Present thinking is that depression also has a genetic and early environment component to it. ${ }^{550}$ Cattaneo and Riva consider:

stress represents the main environmental components for the susceptibility to mental illness, although it is known that the response to stress is modulated by the genetic signature as well as by a number of other factors, including earlier exposure to adverse life events that may have 'primed' the brain toward enhanced susceptibility. ${ }^{551}$

There are considerable differences in "stress reactivity." Reactivity has been defined in the scientific literature as "the deviation of a physiological response parameter from a comparator or control value that results from an individual's response to a discrete, environmental stimulus." ${ }^{" 52}$ Put simply, there are significant differences in the way that people biologically respond to stress. Broad individual variation has been documented in human adults and children, as well as young and mature laboratory animals. ${ }^{553}$ Those

Comorbidity Survey” (2007) 50(2) Am J Ind Med 143; JL Wang, N Schmitz, CS Dewa, SA Stansfeld "Changes in perceived job strain and risk of major depression: results from a population-based longitudinal study" (2009) 169(9) Am J Epidemiol 1085.

${ }^{550}$ See T Frodl, M Szyf, A Carbelledo, M Gill, L Booij "Integrated functional imaging and genetics in depression and anxiety" (2015) 30 European Psychiatry 119; Soo Hyun Rhee and Angelica Ronald Behaviour Genetics of Psychopathology (Springer, New York, 2014); K Kendler, C Prescott, J Myers and $M$ Neale "The structure of genetic and environmental risk factors for common psychiatric and substance use disorders in men and women" (2003) 60 Archives of General Psychiatry 929. See also the discussion in L Brea Genetics, Health and Society (Emerald Group, Bingley, 2015).

${ }^{551}$ A Cattaneo and M Riva "Stress induced mechanisms and mental illness: A role for glucocorticoid signalling" (2016) 160 Journal of Steroid Biochemistry and Molecular Biology 169.

${ }^{552}$ K Matthews "Summary, conclusions and implications" in K Mathews, S Weiss and T Detre (eds) Handbook of stress, reactivity and cardiovascular disease, (New York, Wiley Interscience, 1986).

${ }^{553}$ J Cacioppo, G Berntson, W Malarkey, J Kiecolt-Glaser, J Sheridan, K Poehlmann, M Burleson, J Ernst, L Hawley and R Glaser "Autonomic, neuroendocrine, and immune responses to psychological stress: The reactivity hypothesis" (1998) 840 Annals of the New York Academy of Sciences 664; A Alkon, L Goldstien, N Smider, M Essex, D Kupfer and W Boyce "Developmental and contextual influences on autonomic reactivity in young children” (2003) 42 Developmental Psychobiology 64; M 
people whose genes predispose them to greater biological effects of stress are referred to as people with "highly reactive phenotypes." In the significant piece by Boyce and Ellis, previous thinking was challenged and the more nuanced "biological sensitivity to context" theory advanced. ${ }^{554}$ Previously: ${ }^{55}$

...vigorous and/or persistent autonomic, adrenocortical, or other biological responses to stressors have been viewed as an atavistic health risk factor, a legacy of physiological responses more commensurate with the perils of prehistoric human environments. As such exaggerated stress reactivity is generally viewed as a maladaptive, monotonically harmful heritage of an ancient preparedness for endangerment.

Boyce and Ellis suggest that the highly reactive phenotypes "may have conferred selective advantages in certain social and ecological contexts during human evolution". 556 Boyce and Ellis found: ${ }^{557}$

Rather than acting as a unidirectional risk factor for poor health outcomes...high-stress reactivity has been shown repeatedly to operate in a bivalent manner, most often escalating the risk of maladaptive outcomes in high-stress contexts, but diminishing such risk and acting protectively under supportive, low-stress conditions.

What this suggests is that for those people argued to be genetically more susceptible, it is also arguably more likely in fact, that their exposure to the current stressful environment caused their particular health problems. In a "but for" style test, had the workplace not have been a high stress environment, their genetic makeup suggests better health outcomes, not worse. Obviously, each case turns on its own facts and causation is both complex and nuanced, but this direction in the research strongly suggests against the simplistic conclusion that stressful early upbringings always lead to poor health outcomes. The purpose of this overview of the research is not to advance any particular view of, or make

Allen and K Matthews "Hemodynamic responses to laboratory stressors in children and adolescents: The influence of ages, race and gender" (1997) 34 Psychophysiology 730; M Meaney "Maternal care, gene expression and the transmission of individual differences in stress reactivity across generations."(2001) 24 Annual Review of Neuroscience 1162.

${ }^{554}$ Thomas Boyce and Bruce Ellis "Biological sensitivity to context: An evolutionary-developmental theory of the origins and functions of stress reactivity" (2005) 17 Development and Psychology 271.

${ }^{555}$ Above, at 272.

${ }^{556}$ Boyce and Ellis, above at n 554554, at 272.

${ }^{557}$ Above, at 283. 
any contribution to, the science of stress-related depression, but rather to highlight the complexity of the psychological, biological and environmental processes at play, which the law will need to be able to respond to.

\section{Stress and Musculoskeletal Disorders}

The final example to be used in developing a model of reform is that of chronic musculoskeletal disorders (CMSDs), and in particular, pain related disorders, and disorders which cannot easily be attributed to an acute injury. While some CMSDs have an "identifiable pathology" such as the compression of a nerve or carpel tunnel syndrome, the majority of others are described as "non-specific" with an unclear underlying cause. ${ }^{558}$ CMSDs of the back, neck and upper limbs are a major cause of morbidity, disability and long term sickness absence, ${ }^{559}$ which have been shown to have a major economic impact internationally. ${ }^{560}$ In New Zealand, CMSDs are considered by the Ministry of Health as a significant and increasing cause of "health loss," 561 and similar in size of effect to that of anxiety and depression. ${ }^{562}$ Lower back pain, in particular, is claimed to be the "leading cause of disability in Australasia." 563 As discussed in previous chapters, the current ACA

\footnotetext{
${ }^{558}$ See Roquelaure, above at n 390.

${ }^{559}$ For international impacts see E Schneider and X Irastorza "OSH in figures: Work-related musculoskeletal disorders in the EU- Facts and figures" (2010) for the European agency for health and safety at work. See also Office for National Statistics "Sickness absence in the labour market" (2012) available on the United Kingdom Government Office of National Statistics website $<$ https://www.ons.gov.uk/>

${ }^{560}$ See Stephen Bevan, Tatiana Quadrello, Robin McGee "Fit for work? Musculoskeletal disorders in the European workforce" (The Work Foundation, 2009).

${ }^{561}$ Health loss is a measure of how much health life is lost to illness, impairment or premature death. New Zealand rates of "health loss" due to musculoskeletal disorders can be found in the New Zealand Burden of Diseases, Injuries and Risk Factors Study, reports from which can be accessed at the New Zealand Ministry of Health $<$ https://www.health.govt.nz/nz-health-statistics/health-statistics-and-data-sets/new-zealandburden-diseases-injuries-and-risk-factors-study>

${ }^{562}$ Nicola Swain and Matthew Johnson "Chronic pain in New Zealand: A community sample" (2014) 127(1388) NZMJ 20, at 21.

${ }^{563}$ International Health Metric and Evaluation Organisation "GBD 2010 Change in leading causes and risks between 1990 and 2010" (IHME, 2013).
} 
excludes any conditions which fall outside of the test in section 30, with ACC case law categorising pain syndromes as "mental" and thus excluding them under section $30(5)(a) .564$

\section{A Lower back pain and work}

Lower back pain provides a good example of complex causation, as there is a significant body of literature linking lower back pain to work, but it is also often attributed to natural deterioration, genetics, psychological factors and a combination of all of the above. Most work-related lower back pain is acute, or short term. It lasts only a few days to a few weeks and tends to resolve on its own with no residual loss of function. "The majority of acute low back pain is mechanical in nature, meaning that there is a disruption in the way the components of the back (the spine, muscle, intervertebral discs, and nerves) fit together and move."565 ACC cover for these acute work-related incidences is typically uncontroversial, as most cases will resolve on their own with minimal intervention. It is chronic pain, which causes the most problems. Chronic back pain is defined as "pain that persists for 12 weeks or longer, even after an initial injury or underlying cause of acute low back pain has been treated." 566

In the Global Burden of Disease 2010 study, a major part of the disability due to lower back pain was found to be related to occupational conditions. ${ }^{567}$ The link between physically strenuous work and back pain is well documented. Recent large scale research indicates that men participating in strenuous work experienced a higher risk of chronic low back pain and women had a higher risk of chronic low back pain with work involving

${ }^{564}$ ACA, s30, Teen v Accident Compensation Corporation and Meikle v Accident Compensation Corporation, above at n 259.

${ }^{565}$ University of Utah Health Sciences "How common is lower back pain?"

$<$ https://healthcare.utah.edu/spine/conditions/lower-back-pain.php>

${ }^{566}$ Above.

${ }^{567}$ T Driscoll, G Jacklyn, J Orchard, E Passmore, T Vos and G Freedman "The global burden of occupationally related low back pain: estimates from the Global Burden of Disease 2010 study" (2014) 73 Ann Rheum Dis 975. 
walking and heavy lifting, compared to sedentary work. ${ }^{568}$ But it is not only physically strenuous work that can be considered a "cause". "Sedentary lifestyles also can set the stage for low back pain, especially when a weekday routine of getting too little exercise is punctuated by strenuous weekend workout." ${ }^{569}$ As work has become less physical, workers get less physical exercise and their risks increase. A large 2018 review of the links between musculoskeletal disorders and psychosocial factors showed that stress impacts on the development and experience of such conditions. ${ }^{570}$

\section{$B$ A role for genetics}

ACC decisions from the late 1990s were heavily influenced by what are referred to in the literature as "the twin studies." 571 This was a series of studies on disc degeneration in identical and non-identical twins, which concluded that "disc degeneration appeared to be determined in great part by genetic influences. ${ }^{" 572}$ This ran contrary to the 1997 New Zealand NIOSH report ${ }^{573}$ that reported "strong evidence" of an association between "work related lifting and forceful movements" and lower back musculoskeletal disorder and a further association with "whole body vibration" exposures. Evidence was also reported

\footnotetext{
${ }^{568}$ Ingrid Heuch, Ivar Heuch, Knut Hagen and John-Anker Zwart "Physical activity level at work and risk of chronic low back pain: A follow-up in the Nord-Trøndelag Health Study" (2017) 12(4) PLoS ONE e0175086.

${ }^{569}$ National Institute for Neurological Diseases and Stroke Low Back Pain Fact Sheet (March 2019) $<$ https://www.ninds.nih.gov/Disorders/Patient-Caregiver-Education/Fact-Sheets/Low-Back-Pain-FactSheet>

${ }^{570}$ Yves Roquelaure above at $\mathrm{n} 390$.

${ }^{571}$ M Battie, T Videman, J Kaprio et all "The twin spine stud; Contributions to a changing view of disc degeneration" (2009) 9 The Spine Journal 47. For discussion of the reliance on these studies in New Zealand see David McLean, Neil Pearce, Christopher Walls and Richard Wigley "The "Twin Study" and the misunderstanding on epidemiology that clouds occupational associations and low back disorder" (2011) 124(1338) NZMJ Online.

${ }^{572}$ M Battie, T Videman, J Kaprio et all "The twin spine stud; Contributions to a changing view of disc degeneration" (2009) 9 The Spin Journal 47.

${ }^{573}$ Bruce Barnard and National Institute for Occupational Safety and Health Musculoskeletal Disorders and Workplace Factors - A Critical Review of Epidemiologic Evidence for Work-Related Musculoskeletal Disorders of the Neck, Upper Extremity, and Low Back (United States Department of Health and Human Services, 1997).
} 
between "heavy physical work" and "work related postures" and lower back disorders. 574 The ACC decision to rely on this study and disregard the contrary evidence has been described by experts in the New Zealand medical profession as a "misunderstanding" of the evidence of causation. ${ }^{575}$ Critics have stated: ${ }^{576}$

Variation is not the same as causation, and heritability is not the same as genetic determination. In twin studies heritability estimates are based on comparisons of the variation in disease across twin pairs, but the percentage of population variation in a disease due to a particular exposure or trait is often confused with the proportion of disease explained by this exposure or trait. The Twin Spine Study attempts to partition the population variability observed into separate components that add up to (at most) $100 \%$. However, when we consider causation rather than variation there is no requirement for the attributable fractions for each risk factor (genetic and environmental) to sum to $100 \%$.

MacLean, Pierce and others conclude that lower back disorders "like all occupationally acquired medical conditions arises as a consequence of a multifactorial mosaic of influences." ${ }^{577}$

\section{C "Natural" deterioration and causation}

Back pain has been considered a "natural" phenomenon and a mismatch of human evolution with the current working environment. Smith puts forward that back pain may be the cost of adopting an upright posture in our relatively recent history: ${ }^{578}$

The vertebrate spine is not, in evolutionary terms, a weight bearing organ. It originated in reptiles and fish. Most other mammals are like cats and dogs, in that they have a horizontal back which is flexible, strong in construction in order to contain the essentially delicate spinal cord, and equipped with muscles and spinous processes which are both protective and mechanically designed to facilitate energy transfer between the fore and hind limbs when walking or running.

\footnotetext{
${ }^{574}$ McLean, Pearce, Walls and Wigley, above at $\mathrm{n} 571$.

575 Above.

576 Above.

577 Above.

578 Dennis Smith "Causality and Spinal Pain: The Problem of Back Pain” in Ian Freckleton and Danuta Mendelson Causation in Law and Medicine (Ashgate Publishing, Aldershot, 2002), at 199.
} 
Smith emphasises the "recentness" of upright postures (less than a million years), with most recent shifts from less than 40,000 years ago. He considers: ${ }^{579}$

\begin{abstract}
A direct result of this recent evolutionary adaptation is that the vertebral discs of the spine, particularly the lower (lumbar) spine, degenerate in early adult life. This is almost certainly directly related to the severe transmitted vertical weight-bearing pressures to which these structures are inevitably exposed. Lifting, carrying, jumping and running all subject these structures to compression and shearing forces of up to 500 kilograms. This results in mechanical damage to the external part of the disc; and subsequently to partial extrusion of the nucleus pulposis of the disc through tears in the annulus fibrosis.
\end{abstract}

Spinal degeneration was first documented by Schmorl in Germany in the 1920s, who had access to the removed spines of fatal accident victims and was able to accumulate a wide dataset spanning ages and circumstances. ${ }^{580}$ This was followed by the British anatomist Biddle, in the 1930s who was able to demonstrate the degenerative process in considerable detail. The first report to the Medical Research Council of England put forward that "degeneration was almost universal" and was related to the age of the individual, comprising almost 80 per cent of people between the age of $30-40 .{ }^{581}$ If deterioration can be observed in 80 per cent of people over the age of 30, it poses an important policy question on how deterioration ought to be treated as a "cause" of lower back pain or the associated incapacity.

\title{
D The complexities of pain
}

ACC appeal cases, like $T e e n^{582}$ and Meikle, ${ }^{583}$ discussed in Chapter Four, highlight many of the problems associated with pain conditions. Pain is difficult to understand, define or measure because of the complexity in the pain response and also because of the subjective nature of self-reporting, which encompasses sensory, emotional, cognitive, and social

\footnotetext{
${ }^{579}$ Above, at 199-200.

${ }^{580}$ G Schmorl and H Junghanns The Human Spine in Health and Disease (Grune and Stratton, New York, 1971).

${ }^{581}$ J Biddle. Lumbar Disc Pathology, Medical Council Special Report No 1 (HMSO, London, 1930).

${ }^{582}$ Teen, above, at $\mathrm{n} 259$.

${ }^{583}$ Meikle, above, at n 259.
} 
components. ${ }^{584}$ The International Association for the Study of Pain defines pain as "an unpleasant sensory emotional experience with actual or potential tissue damage, or describe in terms of such damage." 585 To summarise the process of pain, the body has specialist nerves that detect potentially dangerous changes in temperature, chemical balance or pressure. ${ }^{586}$ These send alerts to the brain, but do not send pain as such, as "all pain is made by the brain." 587

"Nociception" is the term that is used to describe how pain becomes a conscious

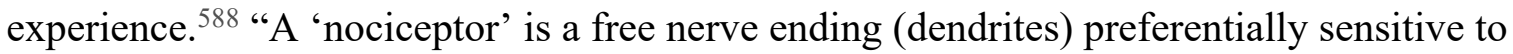
a noxious stimulus or to a stimulus that would become noxious if prolonged." 589 Nociceptors are a highly specialised set of neurons that respond only to pain stimuli ${ }^{590}$ and convert the stimuli into nerve impulses, which the brain interprets to produce the sensation of pain. ${ }^{591}$ The pain is not actually coming from the site of the injury, and is: 592

...the result of the brain evaluating information, including danger data from the danger detection system, cognitive data such as expectations, previous exposure, cultural and social norms and beliefs, and other sensory data such as what you see, hear and otherwise sense.

\footnotetext{
584 AC Williams and KD Craig "Updating the definition of pain” (2016) 157(11) Pain 2420.

${ }^{585}$ International Association for the Study of Pain "Part III: Pain terms, a current list with definition and notes on usage 1194" (April 2017) <http://www.iasp-pain.org/Eduation/Content.aspx>

${ }^{586}$ Lorimer Moseley “Explainer: What is pain and what is happening when we feel it?" (19 November 2015) The Conversation $<$ http://theconversation.com/explainer-what-is-pain-and-what-is-happening-whenwe-feel-it-49040>

587 Above.

${ }^{588}$ D Ignatavicius, ML Workman “Chapter 3: Assessment and care of patients with pain” in D Ignatavicius, ML Workman Medical-surgical nursing: Patient-centered collaborative care (8th ed, Elsevier, St Louis, 2016), at 24-49.

${ }^{589}$ Deborah Ellison “Critical Care Nursing” (2017) 29(4) Clinics of North America 397. A definition of Nociceptors can also be found on the Science Direct website $<$ https://www-sciencedirectcom.ezproxy.auckland.ac.nz/topics/medicine-and-dentistry/nociceptor>

${ }^{590}$ EWK Rosenquist, MD Aronson and M Crowley "Definition and pathogenesis of chronic pain" (2017) on Uptodate.com (online medical resource) $<\mathrm{https}$ ://www.uptodate.com> ${ }^{591}$ NB Patel "Chapter 3 physiology of pain" in Guide to Pain Management in Low-Resources Settings (International Association for the Study of Pain, eBook, 2010), at 14-17.

592 Sapolsky, above at 459, at 189.
} 
As explained succinctly: "the brain is not a mindless pain-ometer, simply measuring units of ouchness." "M93 "Most of what the brain's responses to pain are about is generating emotional responses and giving contextual interpretations about the pain" and this "can be disassociated from the objective amount of pain signal that is coursing up to the brain from the spine." ${ }^{594}$ It is this which has justified ACC's rejection of many claims. However, again the picture is more complex, when it comes to linking the pain to work.

Linnstaedt's work looks at chronic pain following a traumatic exposure. Chronic pain can emerge even where there is "very little or no tissue damage." ${ }^{\text {" } 595}$ Linnstaedt explains that traumatic events cause the stress system to activate, releasing cortisol, the stress hormone discussed earlier in the chapter. ${ }^{596}$

Cortisol is a critical link between trauma and chronic pain. This is because cortisol and another stress hormone called adrenaline have been shown to directly sensitize peripheral nerves - giving it the ability to signal pain in the absence of nerve injury.

Again, this relationship likely has a genetic component to it. A 2018 study in to genetics and likelihood of experiencing post-traumatic chronic pain found "individuals who carry at least one copy of the less common variants, FKBP5-TG or FKBP5-GG, experienced more pain than the individuals carrying only the more common FKBP5-TT variant." 597 These individuals are thought to have differences in their stress response systems and cortisol levels. ${ }^{598}$

593 Above, at 193.

594 Above, at 193.

595 Sarah Linnstaedt "Chronic pain after trauma may depend on what stress gene variation you carry" (28 August 2018) The Conversation <https://theconversation.com/chronic-pain-after-trauma-may-depend-onwhat-stress-gene-variation-you-carry-102021>

596 Above.

597 Sarah Linnstaedt, Kyle Riker, Cathleen Rueckeis, Katrina Kutchko, Lela Lackey, Kathleen McCarthy, Yi-Hsuan Tsai, Joel Parker, Michael Kurz, Phyllis Hendry, Christopher Lewandowski, Elizabeth Datner, Claire Pearson, Brian O'Neil, Robert Domeier, Sangeeta Kaushik, Alain Laederach and Samuel McLean “functional riboSNitch in the 3'UTR of FKBP5 alters microRNA-320a binding efficiency and mediates vulnerability to chronic posttraumatic pain" (2018) 3458(17) Journal of Neuroscience 27.

598 Above. 


\section{E Complex interrelationships}

Local and international research suggests sufferers of back pain typically also experience pain elsewhere. ${ }^{599}$ Many studies have also reported associations with mental health issues, including depression and anxiety. ${ }^{600}$ A New Zealand study revealed "high levels of disability and mental health issues" in people with chronic pain. ${ }^{601}$ Sleep problems also often co-occur with chronic pain, with pain preventing sleep and lack of sleep contributing to pain. ${ }^{602}$ There is also a gender difference present in the experience of pain, with women typically reporting the experience of more pain. ${ }^{603}$ These factors make work-related pain conditions more difficult for the ACC scheme and explain some of the trends in the case law observed during the 1990s and early 2000s. These complexities also support the argument for improving the current cover provisions within the scheme.

${ }^{599}$ O Gureje, M Von Korff, and L Kola et al "The relation between multiple pains and mental disorders: Results from the world mental health survey" (2008) 135 Pain 82.

${ }^{600}$ A Tsang, M Von Korff, S Lee et al. "Common chronic pain conditions in developed and developing countries: Gender and age differences and comorbidity with depression-anxiety disorders" (2008) 9 The Journal of Pain 883; B Baune, R Caniato, M Garcia-Alcaraz and K Berger "Combined effects of major depression, pain and somatic disorders on general functioning in the general adult population" (2008) 138 Pain 310; L McWilliams, B Cox, M Enns "Mood and anxiety disorders associated with chronic pain: An examination in a nationally representative sample" (2003) 106 Pain 127; K Scott, R Bruffaerts, A Tsung et al "Depression-anxiety relationships with chronic physical conditions: Results from world mental health surveys (2007) 103 Journal of affective disorders 113; O Gureje, M Von Korff, and L Kola et al "The relation between multiple pains and mental disorders: Results from the world mental health survey" (2008) 135 Pain 82.

${ }^{601}$ Swain and Johnson, above at $n 562$.

${ }^{602}$ See for example N Tang, C Goodchild and A Sanborn et al "Deciphering the temporal link between pain and sleep in a heterogeneous chronic pain patient sample: A multilevel daily process study (2010) 35 Sleep 675.

${ }^{603}$ A Tsang, M Von Korff, S Lee et al. "Common chronic pain conditions in developed and developing countries: Gender and age differences and comorbidity with depression-anxiety disorders" (2008) 9 The Journal of Pain 883. 


\section{Conclusion}

As explained above in Chapter Three, this thesis adopts a labour law approach to the aim of law reform. Reflecting this approach, it is important to start the analysis with the work performed and the economic, social and political relations of that work which impact on the hazards that workers are exposed to and the development of subsequent health problems. This chapter demonstrates that the growth in stressful work and work-stressrelated illnesses makes reform to the cover provisions of the ACC scheme an urgent, but complex task, if the goals are to be achieved. This chapter has provided an overview of relevant research in to work stress and the development of some of the most common workrelated health problems, highlighting the complex interrelationships between genetics, lifestyle factors, early life stress, the natural deteriorations of aging, and the stressful working environment. These health conditions raise some of the biggest causal issues that need to be addressed and also some of the biggest policy questions. The following chapters address those issues. 


\title{
CHAPTER SIX: DEVELOPING A NEW APPROACH TO CAUSATION
}

\author{
A Purposive Approach to Causal Connection
}

\section{Introduction}

The relationships between work and workers' health are often complex, interrelated and difficult to isolate. The previous chapter outlined the changing nature of work and medical thinking on these relationships, providing three examples of stress-related illness with complex causal connections to work. This chapter analyses the issues of causation further to develop a new approach to the evaluation of causal evidence that is better suited to compensating chronic work-related health problems. This is done in two parts. Part one briefly surveys the theoretical approaches to causation and the additional causal uncertainties raised by chronic work-related health problems. Part two draws on narrative theory, identifying the impacts of disciplinary and cultural influences on the creation of causal narratives surrounding work-related health. This theoretical examination forms the basis for a new approach to the assessment of causal relationships, arguing that clarity of principle in the framing of causal questions offers the best response to factual complexity, and also the best prospect of achieving the aims of this thesis. The new approach to causation is developed in to a new Act in Chapter Seven, with the drafting explained in Chapter Eight. 


\section{The Additional Causal Challenges of Chronic Health Problems}

Chronic health problems pose a set of causal challenges that the "accidents" covered by section 25 of the ACA typically do not. Unlike the majority of "accidents" which involve simple, observable, and discrete phenomena (e.g. being crushed by a log), chronic health problems introduce a significant number of causal uncertainties. As set out in the previous chapters, medical thinking is moving rapidly on the complex and interrelated factors at play in many chronic illnesses. Achieving the goals of this project requires a new approach to causation to be developed. "Causation" is the subject of much theorising and debate in science, philosophy and law. ${ }^{604}$ Given the lengthy and often highly abstract range of ideas advanced, this thesis cannot, nor would it be especially useful to, provide a full review of the philosophies of causation. ${ }^{605}$ That said, it is useful to start with some theoretical framework and an understanding of how the different disciplines that interact with the ACC scheme think about causal relationships.

\section{A Theories of causation}

Theories of causation are divided broadly in to two schools: systemic and physical causation. Physical causation theories primarily arise from the hard sciences, articulated by

\footnotetext{
${ }^{604}$ See Kay Codell Carter The rise of causal concepts of disease: case histories (Burlington, Ashgate, 2003); Micheal Bracken Risk, chance and causation: Investigating the origins and treatments of disease (New York, Yale University Press, 2013); Rafealla Campaner "Philosophical theories of causation for epidemiology" (2010) Epedemiogia e prevenzione 34(1) 48; Keith Allen and Tom Stoneham Causation in modern philosophy (NY, Routledge, 2011); Helen Beebee (ed) Making a difference: Essays in the philosophy of causation (Oxford, OUP, 2017) and Christopher Hoerl, Teresa McCormack and Sarah Beck Understanding counterfactuals: Understanding causation issues in philosophy and psychology (Oxford, OUP, 2011).

${ }^{605}$ For further explanation see Stephen Mumford and Rani Lill Anjum Causation: A very short introduction (Oxford, OUP, 2013); Michael R Waldmann (ed) The Oxford handbook of causal reasoning (Online, OUP, 2017); HLA Hart and Tony Honoré Causation in the law ( $2^{\text {nd }}$ ed, Oxford, OUP, 1985); Min Soo Jung An investigation of the causal inference between epidemiology and jurisprudence (Singapore, Springer, 2018).
} 
people like Wesley Salmon and Phil Dowe. ${ }^{606}$ This approach focuses on "conserved quantity causation", whereby an event necessarily involves a change in quantity of some conserved property of some specific entity, e.g. a change in the kinetic energy of a particle. ${ }^{607}$ Analysis at this detailed level has many obvious advantages, representing a truer scientific cause, but is not particularly practical or appropriate for determining workrelatedness in situations as complex as chronic illness. While technology is increasing rapidly, at present there simply is not the knowledge nor the technology available to allow for that level of causal analysis.

Systemic theories of causation offer more assistance and can be seen in the drafting of the ACA and subsequent case law. The work of Australian philosopher John Mackie, for example, proposes that 'causes' are at a minimum INUS conditions, that is, "insufficient but necessary parts of a condition which is itself unnecessary but sufficient" for their effects. ${ }^{608}$ For a condition to be "necessary" within this approach, it means that logically P cannot be true unless $\mathrm{Q}$ is true, and whenever $\mathrm{P}$ is true, so is $\mathrm{Q}$. If $\mathrm{P}$ is a necessary cause of Q, then the presence of Q necessarily implies the prior occurrence of P. "Sufficiency" can be understood as, if $\mathrm{P}$ is sufficient for $\mathrm{Q}$, then knowing $\mathrm{P}$ to be true is adequate grounds to conclude that $\mathrm{Q}$ is true. However, knowing $\mathrm{P}$ to be false does not meet a minimal need to conclude that $\mathrm{Q}$ is false. Essentially, for a cause to be sufficient wherever the cause happens so too will its effect. To explain this more simply for a workers' compensation context we can use the fictional example of Worker A below.

Worker A worked in the construction industry for 22 years, which involved regular and repeated exposure to asbestos containing construction materials. He has been diagnosed with asbestosis. ${ }^{609}$ Asbestos exposure is a "necessary" cause of asbestosis. Exposure to

\footnotetext{
${ }^{606}$ See Wesley Salmon "Causality without counterfactuals" (1994) 61 Philosophy of Science 2297 and Phil Dowe "The conserved quantity theory of causation and chance raising" (1998) 44 Philosophy of Science 486.

${ }^{607}$ Above.

${ }^{608}$ John Mackie "Causes and Conditions" (1965) 12 American Philosophical Quarterly 245.

${ }^{609}$ Asbestosis is a type of pulmonary fibrosis which is a condition in which the lung tissue becomes scarred over time.
} 
asbestos, is required to develop asbestosis, and logically one cannot develop asbestosis without exposure to asbestos (asbestosis is by definition a disease resulting from the chrysotile fibres of asbestos scarring the lungs). Asbestos is not however a "sufficient" cause of asbestosis. Exposure to asbestos does not mean that asbestosis will occur. A great many people are exposed to asbestos who will not go on to develop asbestosis. Asbestos is, adopting Mackie's analysis, insufficient but necessary for asbestosis. For Mackie the sufficient condition for an effect comprises the entirety of the circumstances that existed at the time of the effect and includes all of the necessary conditions. For example, asbestosis develops over time in a given range of circumstances (the entirety of which are unobservable and presently unknowable). Those other conditions may be necessary (e.g. lung tissue susceptible for scarring) but not sufficient. The sufficient condition for asbestosis includes all of these factors, the known necessary conditions and the presently unknown.

Mellor builds on Mackie's analysis and presents a probabilistic account of causation. ${ }^{610} \mathrm{He}$ argues that an event can be considered its cause where it increases the chance of its effect event. Mellor proposes that a cause is sufficient for its effects if, and only if, the cause entails the chances of the effect equalling one. For Mellor a cause should be considered necessary for its effect if, and only if, the absence of the cause entails the chances of the effect equalling zero. ${ }^{611}$ Applied to Worker A, exposure to asbestos does increase the chances of the worker developing asbestosis, meaning it is a cause, but not to a probability of one, and as such should not be considered sufficient. It would be considered a necessary cause as the absence of exposure results in a likelihood of developing asbestosis at a probability of zero. For Mellor, the probability of something occurring ranges from zero to one, with asbestos exposure causing asbestosis able to be given a value between zero and one. If the cause is only sometimes followed by its effect, as in the case of asbestosis, it is not sufficient. ${ }^{612}$

\footnotetext{
${ }^{610} \mathrm{D}$ H Mellor The Facts of Causation (Taylor and Francis, London, 1998).

${ }^{611}$ Mellor, above.

${ }^{612}$ However, there may be situations where the effect sometimes occurs in the absence of a particular cause, or where multiple causes may have similar effects. In such cases it is not considered a necessary cause and
} 
Both the deterministic (Humeian) causation of Mackie and the probabilistic causation of Mellor help in understanding the relationships between causes and effects. The thinking on and categorisation of occupational health conditions will often echo the INUS model of Mackie and/or the probabilistic model of Mellor. ${ }^{613}$ The models are usefully applied where there have been "accidents". For example, getting your hand caught between the blades of a cutting machine (the application of external force under section 25) is from the Mackian or Mellorian perspective, likely a sufficient cause, representing an increase in probabilities to one. The current tests are drafted either on the assumption of an easily knowable mechanistic cause (e.g. the impact of an external object on a human body) or enough epidemiological data to assign a clear increase in probability to a causal factor in producing the subsequent effect.

While these models provide a good starting point for the analysis of accidents, they are less helpful in determining causation in cases of chronic disease, requiring more information about the causal variables at play than is typically available. As set out in the examples in the previous chapter, the causal factors involved in the development of chronic health problems are typically so complex and interrelated that the application of a Mackian or Mellorian analysis on its own will offer little assistance.

\section{$B$ Some of the additional uncertainties in the evidence}

Sandy Steel has provided a classification system for causal uncertainties in the law which can be applied here. ${ }^{614}$ Steel's first causal uncertainty is "uncertainty over general and

may be only part of the totality of circumstances which are sufficient, increase the probability of an effect in a conditional manner or in combination.

${ }^{613}$ See Jos Verbeek "When work is related to disease, what establishes evidence for a causal relation?" (2012) 3(2) Saf Health Work 110; and Swaen G van Amelsvoort "A weight of evidence approach to causal inference" (2009) 62(3) J Clin Epidemiol 270.

${ }^{614}$ Sandy Steel Proof of causation in tort law (Cambridge University Press, Cambridge, 2015). 175 
specific causation."615 General causation questions ask whether $c$ can cause $e$ e.g. can exposure to benzene cause leukaemia? Specific causation questions ask whether $c$ caused $e$ on a specific occasion e.g. did Worker B's exposure to benzene working in an agricultural chemical plant from 1981 to 2003 cause his leukaemia? While most accidents provide easily determinable explanations of both general and specific causation, for chronic health claims, there will almost never be certainty or clarity in the available evidence on a worker's particular exposures or the development of a given disease.

This leads to the second class of causal uncertainty identified by Steel: "factual and scientific causal uncertainties". These causation questions arise when decision-making bodies are faced with technical evidence of causation, presented by experts, which goes well beyond general knowledge. ${ }^{616}$ These uncertainties include questions around the probative force of statistical evidence, disagreement between scientific experts over the existence of a causal relationship, and questions about the reliability of scientific evidence. These uncertainties will often be present in cases involving chronic illness especially where the research is new or contradictory.

Additionally, where there is a difference in understanding and language between lawyers and medical experts (discussed further below), these problems of evaluating evidence can be heightened. Stapleton argues that: ${ }^{617}$

When causation is being discussed among lawyers and scientists, a basic source of difficulty they have in understanding one another is that, when scientists use causal language they are always pursuing facts... If a scientist knows all the facts of how a transition came about, he or she would not consider that there was any room for a dispute labelled as one about "causation" of the transition. In contrast, when lawyers use causal language, they sometimes are applying it to cases where the parties agree about all the facts, but have nevertheless framed their dispute as one about causation.

Steel's third classification relates to the uncertainties associated with time. The passage of time is a cause of uncertainty, and particularly relevant to occupational diseases, which

\footnotetext{
615 Above, at 6.

616 Above.

${ }^{617}$ Jane Stapleton "Scientific and legal approaches to causation" in Ian Freckelton and Danuta Mendelson Causation in Law and Medicine (Routledge, New York, 2002), at 15.
} 
often have long lead-in times. For example, it is often difficult to establish exposures to hazardous substances, dusts or mutagens where the exposure took place many decades prior to the development of symptoms or a diagnosis. Although the new risk management regulations have introduced a requirement to monitor worker health and keep records of such monitoring, such evidence is usually limited and often unavailable. ${ }^{618}$ The greater the time lapse, the more likely also that other factors may confound clear patterns of causation. As discussed in Chapter Five, contemporary working patterns also make the passage of time more difficult, as a given individual may have worked in a number of industries for short periods of time or hold multiple jobs at the same time. The current tests for causation are particularly problematic for workers in the more "flexible" parts of the labour market.

Uncertainties can also arise from both the multiplicity and similarity of causes. Where there is only one possible cause and effect (e.g. falling from height on to concrete) there are few issues, but chronic health conditions will almost always have multiple causes. Workers rarely use parts of their bodies or minds exclusively for work and the body does not neatly confine its organs to isolated functions. For many health conditions it is possible that different causally sufficient sets of circumstances can bring about the same effect, and these circumstances may operate in a similar way. For example, the same respiratory illness could be caused by work-related exposures (e.g. hazardous substances exposure while road sealing) or non-work exposures to the same or similar substances (e.g. smoking and hobby car racing).

Section 30 is presently drafted to require that the hazard not be present in any materially significant way outside the given task or working environment. This is especially difficult for stress-related illnesses, as few workers will be lucky enough to have so little stress in their lives to say it is "not found to any material extent" in their outside of work environments. A person may be exposed both to work-related stress and also stress at home, and these stresses may be interrelated, as workers are rarely able to limit the functions of their autonomic nervous systems solely to their working hours. Mental and

\footnotetext{
${ }^{618}$ Health and Safety at Work (General Risk and Workplace Management) Regulations 2016.
} 
emotional tasks may also overlap or blur between work and home, for example, a nurse or social worker may experience caring demands at work and also be a parent or caregiver outside of work, adding to their total emotional load.

Finally, many work-related health problems are unobservable (e.g. the accumulation of stress hormones, the mutation of cells, or the decaying of tissue). While most "accidents" in section 25 will be observable (burns, falls, crushing etc.), most chronic illnesses emerge in ways that cannot be seen. For example, the mechanism by which asbestos causes mesothelioma is unobservable in the human body, as is the mechanism by which stress hormones cause depression. Related to this, the "absence of mechanistic knowledge" can cause uncertainty. While there may be a considerable body of statistical evidence that $\mathrm{c}$ can cause e, there may be little understanding of the mechanism by which it does so, as in the case of asbestos and mesothelioma or stress and depression. To establish that a particular exposure caused a given disease, and not some other potential cause, it is helpful to have an established mechanism by which it does so.

\section{Responding to complexity and uncertainty in the causal evidence}

When it comes to chronic disease, there will rarely ever be a case where evidence presents a simple, clear or "sufficient" cause, within the logician's meaning of the word. At present, and for the foreseeable future, the evidence on most chronic illnesses will be complex, and not able to be perfectly understood, involving the interaction of an array of genetic, environmental, economic and social factors. No human being (and presently no functions of artificial intelligence) can hold the vast array of factors potentially at play in a life time of exposures, mapping the entirety of the interactions nor assigning to them precise probabilistic values. Yet, decisions need to be made, and are made, allowing for practical actions to be taken, and "efficient causes" to be selected. When posed with such complexity decision-makers are not "determining a true cause," but rather selecting from the range of causal conditions and elevating selected factors to the status

of cause for a given purpose. To respond to the complex causal problems of chronic 
health conditions an approach is needed which provides a mechanism for the selection of causal factors and the assignment of efficient cause where there is inadequate evidence to determine a "true" scientific cause.

If decision-makers are selecting a causal factor and elevating it to the status of cause, then the analysis needs to focus on how and why particular causal conditions are being selected. For this, narrative theory offers some assistance. To narrative theorists, when faced with complexity humans create narrative, allowing for understanding and efficient responses in the real world. The British philosopher Peter Goldie asserts that humans have an inherent mental tendency to put events into narrative, to select plot elements and to string them together in a way that makes a coherent story, a process he calls emplotment. ${ }^{619}$ Rather than an accurately recalled list of events, or pattern of interrelationships, the mind creates a narrative that draws together happenings and creates the connections and relationships between them, or as the phenomenologist Ricoeur puts it, "extracts a configuration from a succession." 620 The narratives that people tell themselves about a given event reflect pre-existing lived, or heard, explanatory narratives, including the different learned disciplinary approaches.

Consider first a very simple "accident" scenario, of a worker breaking a leg on a slippery floor. There is a causal relationship between A, the slippery floor, and B, the broken leg. A is not sufficient for B in that, slippery floors do not always cause broken legs. In reality there are potentially hundreds of causal factors, even in a very simple scenario, which could be included in the causal story, such as the actions of the person who spilled the water on the floor, the person who failed to clean the floor, the worker's choice of shoes with worn tread, the speed with which the worker was walking and the worker's distraction while walking. When asking the worker what caused the accident, they may say "the slippery floor." The slippery floor is the phenomenon most 'out of place', or the factor that should not have been there, and thus in the mind of the worker the most aberrant factor is elevated

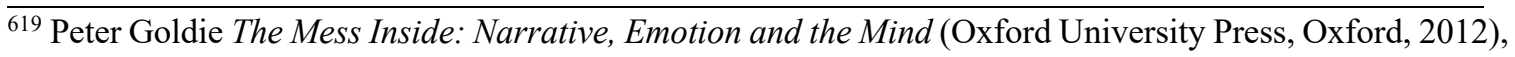
at 11 .

${ }^{620}$ Paul Ricoeur Time and Narrative (University of Chicago Press, Chicago, 1984), at 66. 
to the most causal. When asking what caused the accident the worker could also say: "I was so distracted by what happened in the meeting just prior, that I wasn't paying enough attention." Here the worker has selected the factor they feel most responsible for, elevating self-admonishment to cause. Likewise, the worker could say "the employer's lack of cleaning" was the cause, with the anger over the employer's failure to meet a duty to the worker elevated to the cause. Following the approach of the narrative theorists, even simple stories of causation are influenced by the context and perspective of the story teller.

Lawyers, doctors and occupational health researchers are not immune to this process. When faced with a causal question that cannot be answered adequately by the available evidence, professionals create a narrative of causation which generally reflects the context posing the causal question, and the objectives, cultural stories and norms of the given discipline. The narrative elevates one of the causal conditions and assigns it the status of cause. Although rarely consciously articulated, lawyers and doctors think about causation in very different ways, and the question of "does work cause a given illness?" will be answered very differently depending on whether it is framed as a legal or medical question. Consider the disciplinary narratives in Worker A's asbestosis below.

\section{Disciplinary and Cultural Impacts on Narratives}

Worker A, described above, has asbestosis and has worked for 22 years in the construction industry handling asbestos containing materials. In the lawyer's story of causation, questions of cause are framed within the context of finding fault and apportioning liability. The question of cause is shaped as "whether it is more likely than not an employer's breach of its legal duty to ensure worker A was not exposed to the asbestos resulted in exposure sufficient to create the required nexus?" That question then sets up a set of linked sub questions informed by case law, the legal relationship between the employer and Worker A, the nature of legal duty owed, the accepted standards of discharging that duty and the available knowledge at the time. What matters is the legal obligation, knowledge of the risk, and "reasonableness" of actions taken, factors surrounding the decisions that resulted in breach, and a sufficient connection between the damage to that breach. 
The examination of the causal facts takes place after an examination of the duty and is informed by it. It is further informed by the burden of proof with the claimant only required to show a link existed "on the balance of probabilities." In evaluating the evidence for a "cause" a judge is looking to the purpose of the given duty, the express objects of relevant legislation, notions of community standards or justice and the fairness of the consequences to the individual parties. The likely cause selected from the multitude of competing factors is framed as the employer's breach. Honoré argues that "[h]uman responsibility links causation and the law." ${ }^{621} \mathrm{He}$ argues that: ${ }^{622}$

In ordinary language there is a close link between causation and responsibility even when natural events are concerned. The Plasmodium parasite was "responsible" for the patient's malaria. But human responsibility is a narrower notion and rests on different values. It is used to pick out a certain type of cause, namely the person, if any, whose conduct explained what happened. It focuses for example on the person who exposed the patient to the malaria parasite, rather than on the parasite itself. The outcome... is then attributed to that person and they must account for it, as the term "responsible" implies.

As Honoré points out legal liability (one removed from responsibility) is concerned with a different type of cause than the cause of the disease that doctors are concerned with. ${ }^{623}$ In order to determine what consequences a person's conduct has resulted in, lawyers compare the world with or without the person's given conduct e.g. had the person not sent the workers in to given environment they would not have been exposed to the parasite that caused the malaria.

In contrast, the assigned cause in an epidemiologist's story focuses on the fact the industry that Worker A worked in has a statistically significant higher risk of asbestos exposure. ${ }^{624}$ The PMR (proportionate mortality ratio) ${ }^{625}$ of observed deaths amongst workers in that

\footnotetext{
${ }^{621}$ Antony Honoré "Principles and values underlying the concept of causation in law" in Ian Freckelton and Danuta Mendelson above at n 621, at 7.

622 Above, at 8 .

${ }^{623}$ Above.

${ }^{624}$ See Campaner above, at n 604.

${ }^{625}$ See E S Hanson "The proportionate mortality ratio and its relationship with measures of mortality" (1990) 9(3) Stat Med 315.
} 
industry is substantially higher than expected deaths from asbestosis in the population as a whole. This general statistical relationship can be used to infer likely specific relationships. Unlike the lawyer, who is focussed most on their client's outcomes, an epidemiologist is concerned primarily with public health measures preventing asbestosis and so focuses their attentions on exposure to the substances itself and its use in the construction industry. According to McGwin: ${ }^{626}$

Epidemiology has a vested interest in causation as, despite its numerous and often vague definitions, it is a discipline with the goal of identifying causes of diseases (both modifiable and nonmodifiable) so that the disease or its consequences might be prevented.

Cause is framed by the ends of public health and the statistical significance of given correlations. The focus of the casual question is on the methods of analysis, the patterns of exposures in the environment in which the worker works and patterns of disease amongst similar populations. McGwin suggests that the "complex theoretical concepts of disease causation underlying the field of epidemiology are bypassed in favour of the more quantitative concepts of odds, risks and rates." 627 This is attributed to "comfort in numbers" and the dynamics of the relationships between epidemiology and other fields. ${ }^{628}$

To the treating physician, in contrast, the "cause" is chrysotile fibres in white asbestosis (one of six types of asbestos) accumulating in lung tissue. Chrysotile fibres accumulate in the lungs, resulting in fibrosis (scarring), lung tissues thicken, causing pain and restricting breathing. Chrysotile asbestos is commonly used in roofing materials, which Worker A reports exposure to. To the physician, cause operates in the context of finding the correct diagnosis and most effective treatment for the worker affected. The worker presents with the symptoms of asbestosis, tests show fibrosis of the lungs, and patient questioning reveals the worker works in an occupation with a high exposure to chrysotile asbestos fibres and therefore the presumptive cause is asbestosis. Medicine is defined as "the science and

${ }^{626}$ Gerald McGwin "Causation in Epidemiology” (2010) Am Jrnl of Opthamology 599.

${ }^{627}$ Above, at 599.

${ }^{628}$ Above.

182 
practice of the diagnosis, treatment and prevention of disease. ${ }^{~} 629$ When doctors think about the "cause" of a disease, they think about cause in the context of its diagnosis and treatment. ${ }^{630}$ As the disease presents in the lungs and the treatment is focused on the lungs, the "cause" is located in the operation of the lungs.

All three approaches in this example may lead to the same conclusion, that Worker A's health condition was likely caused by work-related exposure to asbestos. However, the emphasis on the most important causal condition differs according to discipline. None of these approaches is wrong and may all assist in the evaluation of a given case, but it is important to understand the differences as in more complex fact scenarios these differences in ascribed cause may result in conflicting causal narratives. For example, Worker A may have also worked as welder for many years prior to his stretch in construction, with exposures to beryllium and cobalt, also known to result in fibrosis in the lungs, complicating the diagnosis of asbestosis (there is no way to definitively test which substance caused the scarring). Welders have even higher rates of respiratory disease. Worker A may have also grown up in a damp house where a parent smoked (generally increasing the risks of respiratory disease). These extra factors potentially change the medical and epidemiological story, to one where the scarring of the lungs is attributable to damp housing, second-hand smoke, and the weakened young lung tissues being exposed to an adulthood of accumulating aggravating exposures. The lawyer's narrative with its emphasis on legal relationships and duties would likely still elevate asbestos exposure to the cause. Each of these ascriptions of cause above can be described as logically valid, although none describe the totality of the logically "sufficient" causal relationships, nor can any prove with perfect certainty the precise causal mechanisms by which Worker A came to have the lung disease he now suffers. Disciplinary differences impact on the explanatory causal narratives of disease created. These differences make the drafting of the ACC cover test particularly important, as will be discussed later in this chapter.

\footnotetext{
629 "Medicine" in Oxford English Dictionary Online (3 May 2019) at:

$<$ https://en.oxforddictionaries.com/definition/medicine $>$

${ }^{630}$ See Carter, above at n 604604; and Bracken above, at n 604.
} 


\section{A Culturally specific narratives}

It is also important to acknowledge that disease is, to an extent, a socially constructed and culturally defined phenomenon, especially in its interactions with policy and regulation. ${ }^{631}$ While there are of course biological realities, testable levels of given hormones or observable changes on an MRI, the ascription of "cause" has an important social and cultural component, impacting on the way individuals think about and experience their own health and the way politicians and law makers conceive of the most appropriate response. Researchers highlight that what is recognised as a disease by the medical profession are historically and contextually specific. ${ }^{632}$

To illustrate this point, it is useful to consider the approaches of other jurisdictions in compensating the chronic diseases of workers. The Japanese response to work-stressrelated depression is particularly useful. While the approach in many English-speaking countries has been to individualise depression as a problem of biological malfunction, Kitanaka outlines the Japanese construction of depression and suicide "as a problem of labour." ${ }^{633}$ In Japan, depression has since the 1990s been constructed as a "national disease," attributed to a mismatch between the "traditional work ethic, notable for its loyalty and diligence" and the "neoliberal economy." 634 The Japanese labour movement has successfully established depression as an illness primarily of work-stress, leading to economic compensation and long-term sick leave for affected workers. ${ }^{635}$

\footnotetext{
${ }^{631} \mathrm{C}$ Martin and C Peterson "The social construction of chronicity- A key to understanding chronic care transformations" (2009) 15(3) J Eval Clin Pract 578.

${ }^{632}$ See Carter and Bracken, above at $\mathrm{n}$.

${ }^{633}$ Junko Kitanaka "Depression as a problem of labour: Japanese debates about work, stress, and a new therapeutic ethos" in Jerome Wakefield and Steeves Demazeaux (eds) Sadness or Depression? (Springer, e-book, 2016) (History, Philosophy and Theory of the Life Sciences Series) at 15; See also Junko Kitanaka "The rebirth of secrets and the new care of the self in depressed Japan" (2015) 56(12) Current Anthropology S251.

${ }^{634}$ Kitanaka, above, at 55.

${ }^{635}$ Above.
} 
The Abe government issued the "White paper on Karoshi" outlining additional reforms to tackle work-related mental illness and suicide following a number of high-profile deaths. ${ }^{636}$ Karoshi (過労死) has no exact translation in to English but can be understood as death from overwork or working yourself to death. It is also reflected in Karojisatsu (過労自殺) or overwork suicide. According to the Japanese Ministry of Health, Labour, and Welfare "sudden deaths of any employee who works an average of 65 hours per week or more for more than 4 weeks or on average 60 hours or more per week for more than 8 weeks may be karoshi. ${ }^{{ }^{637}}$ Karoshi comes in two varieties, cardiovascular disease and suicide, and both have karoshi recorded as cause of death, and are compensated. In 2015, 93 suicides were officially recognized as overwork deaths eligible for compensation, and 96 deaths from heart attacks, strokes and other illnesses were linked to overwork. ${ }^{638}$ In addition, there were thousands of mental illness claims brought.

What is worth reflecting on is the way in which cause is framed. The Japanese have access to the same medical science on cardiovascular disease and neurochemistry and yet the ascribed "cause" is work, not a mental illness or cardiovascular disease diagnosis. The difference reflects the two prevailing causalities in depression in the literature. In the first approach, depression is framed as a "biological anomaly" to be detected in the individual and thus the appropriate response focuses on the individual or assigning the individual primary responsibility for ensuring his or her own mental health. ${ }^{639}$ In the second approach,

\footnotetext{
${ }^{636}$ See recent coverage and discussion in English, for example "Japan vows to stamp out "death by overwork' while building 2020 Tokyo Olympics stadium" (13 October 2017) at $<$ www.rt.com/sport/406583-japan-olympics-overwork-death-suicide/>; and Chris Weller "A 31-year-old's 'death from overwork' causes Japan to rethink work-life balance" (6 October 2017) $<$ www.businessinsider.com.au/japan-womans-death-from-overwork-government-rethinks-work-2017$10 ? \mathrm{r}=\mathrm{US} \& \mathrm{IR}=\mathrm{T}>$

${ }^{637}$ For the most recent data see Ministry of Health, Labour and Welfare (Japan) Annual Health, Labour and Welfare Report 2016, available at: http://www.mhlw.go.jp/english/wp/wp-hw10/index.html ${ }^{638}$ Above.

${ }^{639}$ For a discussion of the historical context of the western framing of mental illness as an individual weakness see Harvey Teff Causing psychiatric and emotional harm: reshaping the boundaries of legal liability (Hart, Portland, 2009).
} 
depression is framed as a "kind of normal response to a pathogenic work environment, for which the employer and the government become accountable". ${ }^{640}$

Rabinovich argues that fatigue and depression operate as an innate defence mechanism that protect people "against the danger of a work pursued to extreme." ${ }^{641}$ Prominent Japanese psychologist Shimoda considers it a "biological response for self-preservation." ${ }^{42}$ In his view, people who exhibit "a strong sense of responsibility, diligence and thoroughnessseemed constitionally unable to sense their fatigue and pushed themselves beyond their limits, only to collapse at the height of exhaustion." ${ }^{643}$ In Japan, this personal disposition is seen as a latent product of Japanese socialisation, turning what may have been framed as biological and individual in to something social and cultural, indicative of pathological work ethic. ${ }^{644}$ Following this, the recommended approach is to encourage patients to disconnect from the pathogenic relations of the workplace and encourage greater government intervention. ${ }^{645}$

The Japanese recognition of depression as a work-stress-related illness also followed prominent legal cases involving suicides, such as the 2003 Toyota case. ${ }^{646}$ The defendant employer argued that the worker's depression was as a result of his own vulnerability, and his timesheets showed levels of work not necessarily above his peers. The case for the worker was that it was not the "objective" level of stress but rather how the individual

\footnotetext{
${ }^{640}$ Kitanaka, above at $\mathrm{n} 633$, at 57.

${ }^{641}$ A Rabinovich The human motor: Energy, fatigue, and the origins of modernity (Harper Collins, New York, 1990).

${ }^{642}$ Mitsuzo Shimoda Soutsubyo ni tsuite (1950) 21 Yonago igaku zasshi [Yonago Medical Journal] 3. ${ }^{643}$ Above.

${ }^{644}$ See H Nakai "Saiken no rinri to shite no kinbun to kufu" [Diligence and innovation as an ethic of reconstruction] in Y Kasahara (ed) Soutsubyo no seishinbyori I [Psychopathology of depression I] (Kobundo, Tokyo, 1976).

${ }^{645}$ Y Kasahara "Utsubyo no shoseishinryoho" [brief psychotherapy for depression] (1978) 4(2) Kikan Seishinryoho [Japanese Journal of Psychiatry] 6; T Yokohama and S Iida "Utsubyo no seishin ryoho" [Psychotherapy for depression] (1998) 13 Seishinka chiryogaku [Journal of psychiatric treatment] 87.

${ }^{646}$ For English language discussion of this case see "Toyota widow compensated for work suicide" Japan Times (9 July 3003); See also Kyodo "Nagoya court rules Toyota employee died from overwork" Japan Times (1 Dec 2007) available at: <www.japantimes.co.jp/news/2007/12/01/national/nagoya-court-rulestoyota-employee-died-from-overwork/\#.XNC-EegzaUk $>$
} 
worker experienced stress. The Judges accepted the latter argument, declaring that work standards should not be set at the level of the "average worker" but rather to those most vulnerable to stress, so long as these remain with the acceptable range found among workers performing the same job with similar age and experience. ${ }^{647}$

Legally framing causation in this way has had an impact on the regulatory response. Working hours, including overtime, must be recorded for all workers and these are inspected by labour inspectors. There are maximum regulated numbers of overtime hours. ${ }^{648}$ Businesses in Japan are increasingly being required to actively intervene, forcing workers to take leave and turning the lights in the office out at the end of the day to encourage workers to go home. As set out in previous chapters, one of the goals of the proposed reforms is to contribute to improved health and safety. The way in which a condition is characterised and its accepted causal narrative in the ACC scheme impacts on the framing of the data, and the framing of the problem as one that requires regulator intervention. This thesis does not argue that New Zealand should adopt the Japanese model of karoshi compensation in to the ACC scheme, but highlights the need to acknowledge the conscious selection of cause and the impact of framing cause in a workers' compensation scheme for subsequent regulatory action.

\section{B Māori narratives of disease causation}

It is important to acknowledge also that Māori thinking on disease can be very different to that currently underpinning the drafting of the ACA or to that required to prove causation under the current ACA tests. As mentioned in previous chapters, Māori are more likely to

\footnotetext{
${ }^{647}$ Kitanaka, above n 633, at 59 .

${ }^{648}$ English version of the legislation can be accessed on the Japan External Trade Organisation website "Section 4.5 Legislation on working hours, breaks and days off" at:

$<$ www.jetro.go.jp/en/invest/setting_up/section4/page5.html > English language commentary can be found at Proskaur Rose "Japan's labor reform caps overtime in bid to curb karoshi" Lexology (10 December 2018) at <www.lexology.com/library/detail.aspx?g=36324f78-5923-490b-8851-6757457883f4>
} 
experience mental illness, ${ }^{649}$ more likely to be exposed to occupational hazards, ${ }^{650}$ and have worse outcomes from cardiovascular diseases. ${ }^{651}$ Further, as highlighted in the Mauri Ora Associates Report the needs of Māori have been poorly met by the ACC scheme in the past. ${ }^{652}$ There is a growing body of research in to Māori mental health and the unique causal connections between work and mental illness. ${ }^{653}$ Research in to Māori experiences of work stress indicates that the experience of stress may be very different for Māori than for nonMāori, especially in relation to institutional racism, lack of cultural safety and lack of recognition for cultural competencies. ${ }^{654}$ The New Zealand Psychologists Board defines "unsafe cultural practice" as that which "comprises any action which diminishes, demeans or disempowers the cultural identity and wellbeing of an individual, family or group." ${ }^{655}$ This is a dimension rarely considered in the case law or in ACC reviews.

Responding to this research, the Mahi Oranga framework for work stress was developed, allowing for the well-known Te Whare Tapa Whā model of health to be incorporated in to work stress measures. Te Whare Tapa Whā is a model of Māori health in which four

\footnotetext{
${ }^{649}$ OECD above at $\mathrm{n} 10$.

${ }^{650}$ Amanda Eng, Andrea't Mannetje, Lis Ellison-Loschmann, Dave McLean, Soo Cheng and Neil Pearce "Ethnic differences in patterns of occupational exposures in New Zealand" (2011) 54 American Journal of Industrial Medicine 410.

${ }^{651}$ Ministry of Health Statistics, above at n 384.

${ }^{652}$ Mauri Ora above at $\mathrm{n} 356$.

${ }^{653}$ See David Brougham and Jarrod M. Haar "Collectivism, Cultural Identity and Employee Mental Health: A Study of New Zealand Māori” (2013) 114(3) Social Indicators Research 1143; C Houkamau and C Sibley, "Māori cultural efficacy and subjective wellbeing: A psychological model and research agenda" (2011) 103(3) Social Indicators Research 379; G Mark and A Lyons "Māori healers' views on wellbeing: The importance of mind, body, spirit, family and land" (2010) 70(11) Social Science \& Medicine 1756; E Muriwai, C Houkamau and C Sibley "Culture as cure? The protective function of Māori cultural efficacy on psychological distress" (2015) 44(2) New Zealand Journal of Psychology 14.

McNeill, H. (2009). Māori models of mental wellness. Te Kaharoa, 2, 96-115

${ }^{654} \mathrm{R}$ Sisley and D Waititi Te pikaungamahi me te kohukihuki (Workload and stress): A national survey of Maori ASTE Te Hau Takitini o Aotearoa members. (Association of Staff in Tertiary Education and New Zealand Council for Educational Research, 1997); and Lisa Stewart and Dianne Gardner "Developing Mahi Oranga: A Culturally Responsive Measure of Māori Occupational Stress and Wellbeing" (2015) 44(2) NZ Journal of Psych 79.

${ }^{655}$ New Zealand Psychologists Board Cultural competencies: For psychologists registered under the Health Practitioners Competence Assurance Act (2003) and those seeking to become registered (New Zealand Psychologists Board, Wellington, 2011), at 15.
} 
essential components of health are symbolised by the four walls of a house. Taha wairua represents the spiritual side, taha hinengaro represents the thoughts and feelings side, taha tinana, the physical side and taha whanau, the extended family side. ${ }^{656}$ All four quadrants are necessary for strength and balance, although Durie asserts that Māori generally feel that taha wairua is the most essential requirement for health. ${ }^{657}$ This has been reflected in Hua Oranga, which is a Māori measure of general mental health, and uses the Māori Outcomes Dimension Framework (MODF) ${ }^{658}$ and also in Mahi Oranga which is specific to work stress. ${ }^{659}$ This model of work stress is provided in the diagram below.

What is important to note about this model is the interrelationships between the factors, the holistic approach to the health of the person, and the layered interactions of the human being with the environments of work. This defies purely probabilistic or linear approaches to causation, and results in the construction of very different narratives on the relationships between the person and their work. When the Mahi Oranga framework was applied to workers the results indicated a much more complex set of interactions than typically considered as evidence in ACC cases. ${ }^{660}$

\footnotetext{
${ }^{656}$ Mason Durie Waiora: Māori health and development (2nd ed. Oxford University Press, Auckland, 1998).

657 Above.

${ }^{658}$ T Kingi and M Durie "Hua Oranga": A Māori measure of mental health outcomes. (Te Pūmanawa Hauora, School of Māori Studies, Massey University, 2000).

${ }^{659}$ Lisa Stewart and Dianne Gardner "Developing Mahi Oranga: A Culturally Responsive Measure of Māori Occupational Stress and Wellbeing" (2015) 44(2) NZ Journal of Psych 79.

${ }^{660}$ Above.
} 


\section{Diagram of the Mahi Oranga Framework: ${ }^{661}$}

Figure 1. Mahi Oranga framework, including domains, dimensions, MODF components and conceptualisations.

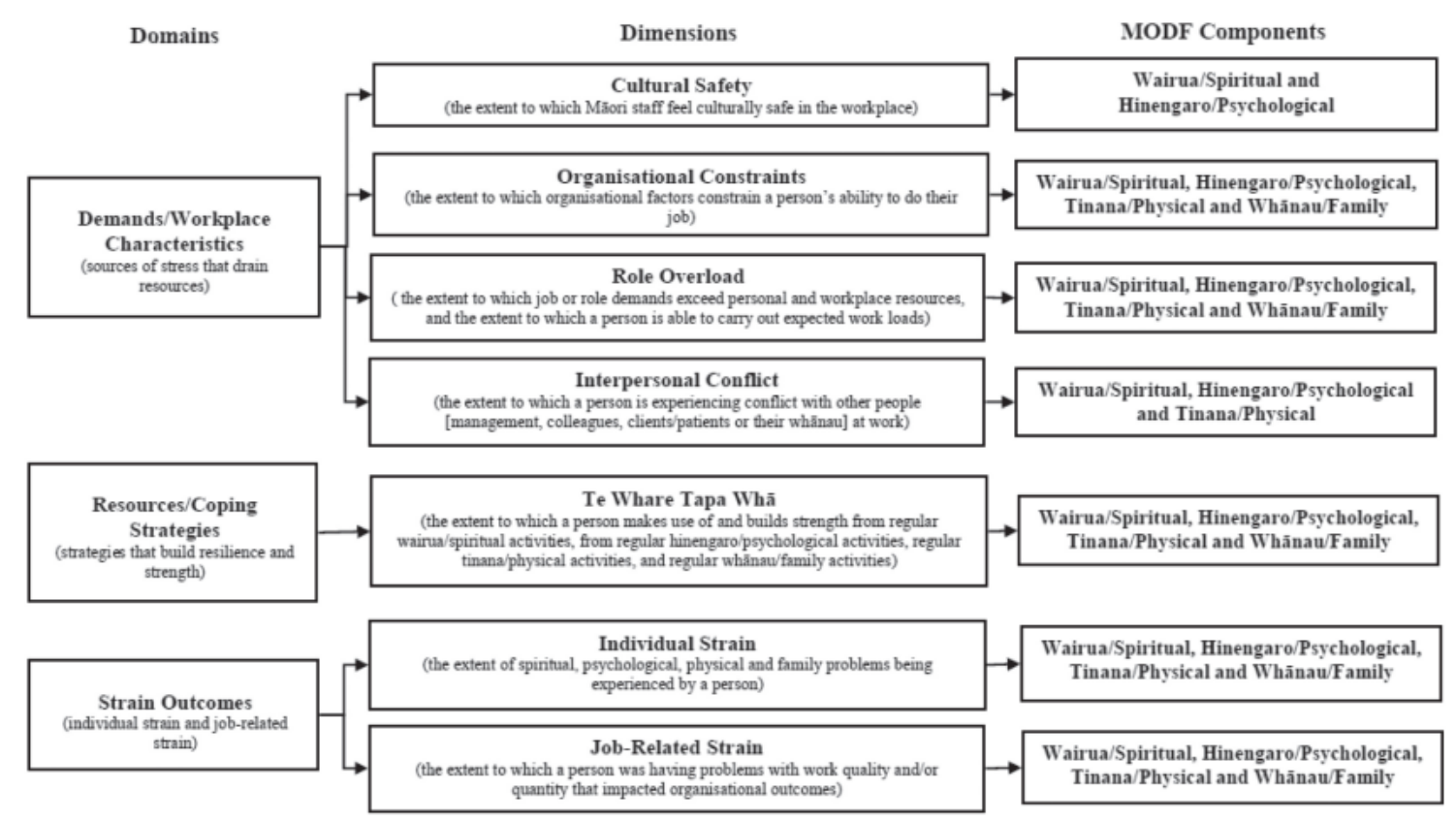

\section{Politically influenced narratives}

The labour law approach taken in this thesis, outlined in Chapter Three, also requires a consciousness of the political and economic factors and the impact of power relations in what is selected for the dominant narrative of cause. Even in a no-fault scheme, where an employer is not directly liable, the boundary line for who receives cover also operates as a boundary line for the responsibility of the owner of a business for the consequences of that activity. Widening the scope of what is considered "work-related" widens the scope of what is included within the employer/PCBU's ambit of responsibility. ${ }^{662}$ There is an important conceptual link between the health and safety obligations and the ACC cover of work-related health problems. "Work-related" health conditions fall squarely within the

\footnotetext{
${ }^{661}$ Diagram published in Lisa Stewart and Dianne Gardner, above at $\mathrm{n} 659$.

${ }^{662}$ The HSWA imposes obligations on a PCBU, person conducting a business or undertaking. The PCBU may be the employer or it may be another entity (e.g. a primary contractor) with responsibilities for the health and safety of workers.
} 
ambit of section 36 of the HSWA and the primary duty of a PCBU. When a health problem is declared to be "work-related" for the purposes of ACC, that categorisation extends beyond ACC, impacting on health agencies, insurance companies, other government bodies, as well as the workplace. That categorisation also impacts on the thinking of the worker as to the cause of their health problems.

Limiting cover primarily to "accidents," being immediate, observable and temporally connected to the place of work, limits the resulting field of responsibility to that type of harm. Extending ACC cover to the health effects of stress, and including a greater range of stress-related illnesses within the scope of "work-related" may start to extend the politically and socially assigned responsibilities of employers/PCBUs, placing those health conditions more obviously within the ambit of section 36, and the sights of the regulator. This may also increase the expectations of workers, who, in framing their condition as work-related, may demand more action from their employer.

Employers and business groups, both in New Zealand and globally, have typically favoured an individualising and in some cases victim-blaming narrative of work-related health problems. This is especially evident at the moment in relation to stress and mental illnesses, laying responsibilities on workers' individual personalities and poor lifestyle choices or even the lack of fortitude of the entire "millennial" generation. ${ }^{663}$ This pattern can also be seen in recent history, in the "accident proneness" narratives of the early $20^{\text {th }}$ century, discussed in Chapter Four, the relegation of repetitive strain injuries to the inherent weaknesses of women's scrawny wrists, and the narratives of Lebanese (Australia) and Māori and Pacific (New Zealand) workers physiologically weaker spines rather than their back-breaking labours in the 1980s and 1990s. ${ }^{664}$

\footnotetext{
${ }^{663}$ See Author Unknown "Staff call: Bosses need to watch workers' mental health" (8 Jan 2018) New Zealand Herald <www.nzherald.co.nz/nz/news/article.cfm?c_id=1\&objectid=11971236>; Kelly Wright

"Avocadoes and selfies: Down with this generation of snowflakes" (8 May 2019) Stuff $<$ www.stuff.co.nz/opinion/112389115/avocados-and-selfies-down-with-this-generation-of-snowflakemillennials>

${ }^{664}$ See Michael Quinlan "Psychological and sociological approaches to the study of occupational illness: A critical review" (1988) 24(2) ANZJS 189; See also Robert Crawford "You are dangerous to your health:
} 
The political and social link between what is considered "work-related" and what an employer is considered socially and ultimately legally responsible for operates at the level of individual illness also, with the assigned cause of a given health problem reflecting the political interests of those involved. This can be seen in the ACC back pain decisions of the early 2000s, discussed in Chapter Five. In these cases, ACC sought to elevate the genetic explanations of back pain conditions, limiting its cover and costs. The ACC decisions over this time period reflect wider trends in the overstatement of the role of genes in explaining diseases. Research suggests that lay people are largely accepting of genetic explanations for health and behaviour and tend to overestimate the heritability of common diseases. ${ }^{665}$ Media portrayals of genetic advances and their applications are often oversimplified and overstated, described as "genetic optimism" in the literature. ${ }^{666}$ Public discussions of causation are often framed as "gene $\mathrm{x}$ has been discovered to cause disease y" when in reality the picture is much more complex.

To explain briefly, a gene is a segment of DNA which codes for and regulates protein production, not a magical wand for creating diseases. The nucleus of a cell contains 46 strands of DNA made up of a series of nucleotides (ACGT). The strand of DNA (which contains the genes) is coiled around a histone. The genetic material in the cell contains this genome and also an epigenome, which are the chemical tags that modify the genome. While it is true that an individual's genome remains the same throughout a person's life, this ignores the role of the epigenome, which change over the course of a lifetime, responding to environmental factors. Environmental factors (including diet, lifestyle, stress, hazardous substance exposures etc.) alter the epigenome influencing which genes are turned on or off

The ideology and politics of victim blaming" (1977) 7(4) Int J Health Serv 663; and Nichols above at n 202.

${ }^{665}$ P Conrad "Genetic optimism: Framing genes and mental illness in the news" (2001) 25 Culture, Medicine, and Psychiatry 225; S Shostak, J Freese, BG Link and JC Phelan "The politics of the gene: Social status and beliefs about genetics for individual outcomes" (2009) 72(1) Social Psychology Quarterly 77.

${ }^{666}$ Conrad, above.

192 
and consequently the production of particular proteins and the functioning of cells. The proteins produced interact with other proteins and chemical signals in the body. ${ }^{667}$

While media reporting often describes the cause of a disease as a particular individual mutation, that may not be the whole story. For mutations within a gene to "cause" a disease it needs to be switched on and this may require an environmental trigger or set of environmental factors to be present. ${ }^{668}$ The proteins produced may not function or may incorrectly interact with other proteins or chemicals within the body. Some diseases require a combination of mutations, a combination of genes, a combination of defective proteins and/or certain environmental triggers to develop. Applying Mellor's approach to causation "a gene" is rarely ever the sufficient cause of a disease (increasing to a probability of one) and may increase the likelihood of disease only where an environmental factor influences the epigenome or a set of other conditions are present. "Nearly every genetic influence is exacerbated or attenuated at some level - be it cellular or social - by the environment." 669 Even disorders once believed to be primarily genetic in origin can have significant environmental influences. ${ }^{670}$

This complexity in the causal relationships is seldom well understood by the general public, with business or political actors able to exploit this in policy debate. When the human genome was first sequenced, the "analysis of the genetic code seemed to be a relatively

\footnotetext{
${ }^{667}$ See Esteban Ballesten "An introduction to epigenetics" in E Ballesten (ed) Epigentic contributions to autoimmune diseases (Advances in experimental medicine and biology e-book series Vol. 711) (Springer, Boston, 2011) at 1-11.

${ }^{668}$ Above.

${ }^{669}$ Brea Perry "The Sociology of, in, and with Genetics: The Role of Medical Sociology in the Era of "omics"' in Brea Perry (ed.) Genetics, Health and Society (Emerald Group Publishing, e- book, 2015) (Advances in Medical Sociology Series, Volume 16), at xi; See also Ballesten, above, at n 667669.

${ }^{670}$ See D Hessl, J Dyer-Friedman, B Glaser, J Wisbeck, R G Barajas, A Taylor and A L Reiss (2001) “The influence of environmental and genetic factors on behavior problems and autistic symptoms in boys and girls with fragile X syndrome" (2001) 108(5) Pediatrics e88; and J Dyer-Friedman, B Glaser, D Hessl, C Johnston, L C Huffman, ATaylor and A L Reiss "Genetic and environmental influences on the cognitive outcomes of children with fragile X syndrome" (2002) 41(3) Journal of the American Academy of Child \& Adolescent Psychiatry 237.
} 
straight forward task." ${ }^{671}$ In the years that immediately followed the mapping of the human genome there was less focus on environment, and more on factors internal and unique to the individual. ${ }^{672}$ It has been argued that advances in genetics coincided with a high point in neoliberal individualism allowing for the dominance of individualised explanations for the causes of disease, divorcing health and well-being from their social context and consequences and fostering the view that illness is the product of faulty genes and individual weakness rather than a reaction to unhealthy social structures or environments. ${ }^{673}$

Overemphasizing the role of genes in diseases, like the overemphasis of "accident proneness" in the dominant narratives, shifts the blame to "individual weaknesses" which distracts from the responsibilities of business or government in preventing these health problems. Researchers warn that "this shifts research, innovation, and resources toward individual-level treatments and interventions, and away from social policy solutions with potential for broader and more egalitarian impact." 674 This "genetic essentialism" 675 may also increase the stigmatisation of conditions that are viewed as immutable or inevitable, such as mental illness. ${ }^{676} \mathrm{As}$ discussed in the previous chapter, the big three of musculoskeletal disorders, cardiovascular disease/stroke and depression/anxiety are all likely to have a genetic component to them. This is also increasingly the case with a wider range of hazardous substance exposure related diseases. ${ }^{677}$ The extent that "genes" should be ascribed the status of cause in a given person's disease is as much a policy question as it is a scientific one, and that needs to be consciously understood in the design of the new causal test.

\footnotetext{
${ }^{671}$ Mark Rothstein, Yu Cai and Gary Marchant "The Ghost in our genes: Legal and ethical implications of epigenetics" (2009) 19 Health Matrix Clevel 1.

${ }^{672}$ Above. See also Perry, above at $\mathrm{n} 669$.

${ }^{673}$ Above.

${ }^{674}$ Perry, above, at xix.

${ }^{675}$ D Nelkin and S Lindee The DNA mystique: The gene as a cultural icon (Freeman, New York, 1995).

${ }^{676}$ See I Dar-Nimrod and SJ Heine "Genetic essentialism: On the deceptive determinism of DNA" (2011) 137(5) Psychol Bull 800. See also Conrad, above at n 665665.

${ }^{677}$ D C Christiani, A J Mehta and C L Yu "Genetic susceptibility to occupational exposures" (2008) 65(6) Occup Envion Med 1.
} 


\section{Conclusion}

This chapter has further examined the issues of causation posed by the previous chapter, identifying the additional causal complexities and uncertainties in determining the cause of chronic health problems. It has argued that where the available evidence is too complex or uncertain to allow for a purely logical or probabilistic causal analysis, decision-makers are forced to select one of the available causal factors and elevate that factor to the status of cause in the explanatory narrative. The decision about which factor is to be elevated is informed by disciplinary biases and the dominant political, social and cultural narratives, as well as the framing of the causal question. Where legislation contains a causal test, the questions framed by that test should be drafted in a manner conscious of the resulting causal narratives and the impact of those narratives on people interacting with the scheme. 


\title{
CHAPTER SEVEN: A NEW MODEL FOR THE COMPENSATION OF WORK-RELATED HARM
}

\author{
Moving Beyond an "Accident" Compensation Scheme
}

\section{Introduction}

Work-related health problems arise from the social, economic and cultural conditions of work, and involve a complex interplay of biological, psychosocial and environmental factors. As discussed in the previous chapter, the framing of the causal question in the compensation legislation sets the framing for the resulting causal narratives explaining work-related health problems. These narratives then impact on employer and government action. The most significant task in the development of a reform proposal is then to develop a new causal test that frames the right type of causal questions, framing the resulting causal narratives in a way that achieves the desired goals of equitable compensation and improved work health and safety. As discussed in Chapter Three, this thesis starts with a set of explicit goals, underpinned by a labour law theoretical framework that seeks to address the inherent inequality of bargaining power, recognise the wrongs of poor health and safety, and the human rights of workers, as well as ensuring equity and dignity for workers accessing compensation. This chapter proposes a new Act to replace the ACA, allowing for the unique needs of work health and safety to be met within a scheme of wider coverage. 


\section{A New Compensation Act}

This thesis proposes a new Act to replace the current ACA. The new Act contains a dedicated Work-Related Harm Part, with a new purpose section and definitions, and a new test for cover reflecting the proposed new approach to causation, shifting the focus from "accidents" to the hazards of work.

\section{A Not an "Accident" Compensation Act}

A key element of the reforms proposed is the removal of "accident" as the entry point in to the scheme and underlying rationale for cover. As discussed in Chapter Four, the problems in the current coverage of work-related health can be viewed as a consequence of the centrality of "accident" to the structure of the legislation. The proposed Act would demote accident to simply one of several categories of cover available. Rather than accident operating as the starting point, with "non-accidents" operating as exceptions, there are multiple category entry points to cover: work-related injuries, treatment injuries, vehicle collision injuries, victim of crime injuries, and finally injuries due to accidents. Each category would be provided for in a new Part of the proposed legislation, as set out in the diagram below. The proposed structure should help to remove the notion that accidents are anything other than a political decision about what should be included, opening the door for further categories of cover in future.

By containing each category within its own Part, it makes transparent the policy rationale for the compensation of those harms. It also allows for more tailored provisions for data collection and review and creates a clearer link between compensation and prevention goals. There are strong reasons why the categories should be based on cause, even if the individual claimant's resulting entitlement is the same. Preventing vehicle collisions, treatment injuries, and work-related health problems are all very different tasks, as each harm arises in a different context, with different social, economic and cultural factors at play. While the justification for separate categories based on cause is especially strong where cover is not universal, as in a scheme with the same scope as the current ACA, it 198 
also holds true where cover is expanded as envisioned by Woodhouse and presently advocated by Forster, Palmer and others. ${ }^{678}$ The proposed reforms in this thesis aim not only to widen coverage but to ensure the scheme can improve health and safety. All harms might be equally deserving of the community level response imagined by Woodhouse, but they are not caused by the same set of factors, and they are not prevented by the same interventions. Particularly where legislation frames the categories for data collection and data then informs the priorities for intervention, decisions about legislative category matter.

While the categories would receive their own Parts, they would still be contained in one scheme. The current ACC scheme already separates the funding for work-related and nonwork-related injuries, alongside a separate mechanism for the funding of traffic-collision related injuries. The model proposed would substantially alter the current legislation and change aspects of the operation, but it would not require a radical transformation of administrative or funding machinery. New Zealand is a small country of just under five million people. Having separate schemes for workers' compensation, traffic injuries, treatment injuries and non-work accidents, as in other larger countries, would be an unjustifiable increase in administrative machinery and cost. The Australian experience provides lessons in the disadvantages of many small schemes with intersecting boundaries. ${ }^{679}$

Within the proposed reforms, all work-related injuries and illnesses would then be grouped together, and treated the same, with "work-relatedness" operating as the unifying policy concept, rather than diagnostic category. Within the work-related harm category, a specific purpose section and causal test would be included, with review panel and data collection machinery informed by the explicit statement of purpose.

\footnotetext{
${ }^{678}$ Palmer, above at n 13, and Forster, above at n 14.

${ }^{679}$ See discussion in Chapter 10 of Richard Johnstone, Elizabeth Bluff and Alan Clayton Work Health and Safety Law and Policy ( $3^{\text {rd }}$ ed, Thomson Reuters, Pyrmont, 2009).
} 


\section{Diagram of New Structure:}

\section{Compensation, Rehabilitation and Harm Prevention Act 2019}

New Purpose Section for the Scheme, reflecting stronger focus on improving health and safety in New Zealand (homes, roads, workplaces, etc) and stronger statement about iniury and illness rehabilitation and compensation.

Part One: Entity creation and governance, operational matters, reporting etc.

Part Two: Work-Related Harm

- New purpose section

- New definitions

- New cover test with indicative list

- New tripartite advisory panel

- New review panel

- New data collection provisions

Part Three: Transport and Vehicle Harm

- New purpose section (goals of road safety etc.)

- Definitions

- Cover test

- Related machinery

- Data collection (relevant to road safety)

Part Four: Treatment Harm

- New purpose section (goals of medical safety etc.)

- Definitions

- Cover test

- Related machinery

- Data collection (relevant to health and disability iurisdiction)

Part Five: Victims of Crime

- New purpose section (relevant to criminal offending etc.)

- Definitions

- Cover test

- Related machinery

- Data collection (relevant to jurisdiction)

Part Six: Accidental Physical Injuries

- New purpose section (relevant to general safety etc.)

- Definitions

- Cover test

- Related machinery

- Data collection (relevant to general safety) 


\section{B A new title for the Act and a new name for the scheme}

A new title for the legislation and name for the scheme will need to be developed, and should be framed more widely, capturing the wider range of functions performed by the scheme and also its purpose in achieving better health and safety outcomes. The naming of schemes is typically a matter for government marketing gurus, rather than legal scholars, but it would be useful to rebrand the scheme in a way that does not include the word "accident" such as "Compensation New Zealand," or better still, adopting a Māori name which alludes to an underpinning concept or set of values for the scheme. Little further attention is paid to the issue of naming the new scheme in this thesis, with the following chapter mostly referring to it as the "proposed scheme." In terms of a new legislative title, something akin to the Compensation, Rehabilitation and Harm Prevention Act 2019 would be suitable, emphasising rehabilitation and harm prevention functions alongside compensation.

\section{New purpose sections}

It is anticipated that each category of cover in the new Act would have its own purpose section allowing for the context and policy objectives specific to that area to be clearly articulated and for the compensation provisions to be drafted to better reflect changes or specific needs in that area. The drafting of the new work-related harm purpose section is discussed in greater detail below and in the next chapter. The new purpose sections for the non-work categories are not drafted in this thesis, as the framing of the policy goals would be better performed by experts in those areas. For example, the prevention and compensation of vehicle collision injuries and the prevention and compensation of medical errors operate in different factual and legal contexts. The purpose sections for these categories should be drafted to reflect the research and theoretical approaches of these fields. Further, should Palmer and Forster succeed in convincing the Government to expand the available categories of cover to incapacities arising in other contexts, this unique context-sensitive drafting becomes even more important. For example, it may be wholly 
inappropriate, if not offensive, to draft a new Part for incapacities present at birth to be focussed on prevention or the recognition of a moral "wrong."

The proposed legislation would need a new overarching purpose section which captures the wider functions of the Act. This new purpose section should move away from "accidents" and incorporate wider statements of principle about the promotion of public health, access to support, treatment and rehabilitation and harm prevention. As discussed above in Chapter Three, there are differences between the goals and principles of labour law and welfare law. The proposed new Act is intended to perform different but coordinated functions, allowing for a well-designed workers' compensation function to contribute to improving work health and safety, and also a welfare function based on a general community responsibility to care for people incapacitated. As discussed in Chapter Three, the goals of labour law and welfare law are different in important ways, but can both be seen as contributing to a fairer and more just society for working people. Both functions can be seen as contributing to a healthier society, ensuring people can access treatment, income support and rehabilitation. These higher-level social goals can underpin the new scheme without compromising the specific goals of the particular Parts. For example, specific goals to improve work health and safety or recognise the rights of workers within the proposed Work-Related Harm Part can be interpreted consistently with a higher-level goal to ensure the health and wellbeing of all New Zealanders. This proposed segmentation of functions allows for a scheme to provide an equal level of care to people affected and also recognise that different harms require different responses if such goals are to be achieved.

\section{Removal of the Occupational Diseases Schedule}

The new legislative Part on work-related harm would contain all the provisions relating to the cover of work-related health problems, whether injury or illness. All work-related conditions would be assessed against a single test. This would eliminate the need for the Occupational Diseases Schedule with its multiple substance or disease specific tests. As discussed above in Chapter Four, the schedule is a product of its history, and is inconsistent with the proposed shift away from "occupational disease status" in determining the 202 
availability of cover. The schedule was first created to reflect the 1927 Workmen's Compensation Convention and the 1934 Convention on Workmen's Compensation (Occupational Diseases). These conventions were intended to create a minimum level of cover for working people in a wide variety of countries and reflect the goals and unique challenges of setting minimum standards in an international context.

For example, the first ILO occupational disease convention contained only three items in its schedule, poisoning from lead, mercury and anthrax. The recognition of each of these diseases has its own political and social history. For example, Anthrax, referred to as "wool sorters disease" had significantly increased in frequency amongst the English woollen mill workers of the $19^{\text {th }}$ century. ${ }^{680}$ Lead poisoning had also become a significant health issue as demand for lead soared in the industrial revolution, ${ }^{681}$ and mercury poisoning, long referred to as "mad-hatters disease" was extending beyond milliners to a range of other occupations. ${ }^{682}$ Many countries passed legislation after 1900 to protect lead workers and these conditions had already gained uncontroversial "occupational" status. ${ }^{683}$ The convention was revised (Convention No. 42) with seven additional diseases added to the previous list. The newly added diseases included four types of poisoning: phosphorus, arsenic, benzene, and halogen derivatives of hydrocarbons of the aliphatic series, and three diseases; silicosis, diseases due to radiation, and skin cancer, as these conditions had won their occupational status in union campaigns. The ten-item list was maintained for 30 years, until it was revised (Employment Injury Benefits Convention No. 121), to add four more poisoning items (manganese, chromium, beryllium, and carbon bisulfide) and rephrasing

\footnotetext{
${ }^{680}$ For the history of anthrax and its recognition see C Holmes Spores, Plagues and History: The Story of Anthrax ( $1^{\text {st }}$ ed, Durban House, Dallas, 2003).

${ }^{681}$ T M Legge and K W Goadby "Poisoning and Lead Absorption: The Symptoms, Pathology and Prevention, with Special Reference to Their Industrial Origin and an Account of the Principal Processes Involving Risk" in T M Legge and K W Goadby Lead Poisoning and Lead Absorption (Edward Arnold, London, 1912).

${ }^{682}$ See Guido Lombardi, Antonio Lanzirotti, Clifford Qualls, Francisco Socola, Abdul-Mehdi Ali and Otto Appenzeller "Five Hundred Years of Mercury Exposure and Adaptation" (2012) J Biomed Biotechnol 1. ${ }^{683}$ Above.
} 
X-rays and radon to "ionizing radiation". ${ }^{644}$ The convention schedules only listed those diseases where there could be a presumption that they were of occupational origin. Paragraph 6-(2) of Recommendation No. 121 provides that "unless proof to the contrary is brought, there should be a presumption of the occupational origin of such diseases." ${ }^{685}$ This approach is suitable for creating an international bottom floor of cover, but not for advancing a contemporary national workers' compensation scheme as a means of advancing worker health and achieving wider health and safety goals.

There is a considerable time lag between advances in research on worker health and the updating of the ILO convention schedules, and sadly, an even greater lag in New Zealand ratifying the revisions and updating the ACA. The proposed cover test provides a mechanism for the expansion of work-related health cover, without health conditions having to be declared presumptively "occupational", receive an ILO resolution, be ratified by New Zealand and enacted in to domestic law. The proposed cover test would not weaken the rights of workers with conditions included in the ILO Schedules and would most likely increase the ease with which these workers could access cover, as well as expanding the cover available to workers with other work-related health problems. In terms of evidencing compliance with the ILO conventions, the legislative provisions, internal cover manuals and resulting data collected on claims could be used.

The removal of the Occupational Diseases Schedule is long overdue. During the debate over the first Accident Compensation Bill in 1972, concerns about the retention of a schedule were expressed, with one Member declaring: ${ }^{686}$

I am concerned about the effect of the Second Schedule. This is a modification, and, to a considerable extent, an extension of the schedule in the Workers' Compensation Act. The limitation of the schedule in that Act has been apparent to members of both the legal and the medical professions for many years, and intermittently over the past 20 years efforts have been made to reconsider this.

\footnotetext{
$\overline{{ }^{884} \text { Eun-A Kim and Seong-Kyu Kang "Historical review of the List of Occupational Diseases recommended }}$ by the International Labour organization (ILO)" (2013) 25 Annals of Occupational and Environmental Medicine 14.

${ }^{685}$ S Niu "ILO list of occupational diseases and health care workers" (2010) 17(2) Asian-Pacific newsletter on occupational health and safety 34 .

${ }^{686}$ (3 October 1972) 381 NZPD 2994 (Accident Compensation Bill - Dr Gerard Wall).
} 
If indeed the schedule was ever a good way to respond to work-related health problems, it is certainly not now, with changing patterns of work and rapidly moving medical research likely to render any inclusions quickly obsolete.

\section{E The new Work-Related Harm Part purpose section}

The drafting of the purpose section in the new Work-Related Harm Part forms a core component of the new approach to causation, creating an explicit statement of policy principle to aid interpretation in boundary-line cases. There is nothing especially novel in taking a purposive approach to legislative drafting, nor the inclusion of purpose sections in enactments. The Interpretation Act 1999, section 5(1) sets out clearly: "The meaning of an enactment must be ascertained from its text and in the light of its purpose" and almost all new enactments come equipped with one or more statements of purpose. The latest Legislative Advisory Committee Guidelines also advocate this approach. ${ }^{687}$ What is new about this proposal is that for the first time in nearly fifty years the proposed legislation will provide an explicit indication of why work-related conditions are covered by the scheme, and the underlying rationale for providing compensation to work-related health problems. ACC has always treated work-related health problems as different and special "exceptions" without an explanation as to why or how the area ought to be developed. The purpose section enables the workers' compensation functions to operate as workers' compensation functions and creates an explicit link between compensation and health and safety goals and an explicit recognition of the rights of workers to receive such compensation.

The purpose section also reflects a labour law approach, referring to the rights of workers to receive compensation, the need for compensation to be fair and equitable, the dignity of workers, and the ends of improved health and safety (discussed further in the next section). While the drafting is discussed further in the next chapter, the link between the explicit aims and the approach to causation is discussed here. Workers have rights to compensation

${ }^{687}$ Legislation Design and Advisory Committee Legislation Guidelines (2018 edition). 
and to health and safety at work, arising from a variety of sources, including the HSWA, UDHR and relevant ILO Conventions. The reference to the rights of workers is intended to provide decision-makers a link to these rights instruments and the jurisprudence surrounding them. The rights of workers to receive compensation are connected with the rights of workers to safe and healthy work. The purpose of the HSWA also states that: ${ }^{688}$

...regard must be had to the principle that workers and other persons should be given the highest level of protection against harm to their health, safety, and welfare from hazards and risks arising from work or from specified types of plant as is reasonably practicable.

The explicit reference to workers' rights and the goals of health and safety are combined with the use of the HSWA definitions of "worker" and "working environment" and the hazard-based indicative list, discussed further in the next chapter. This is intended to send a clear message to decision-makers that the Act ought to be interpreted consistently with health and safety rights and goals.

\section{F New causal test}

The drafting of the test is designed to pose a single causal question for any work-related health problem and be accompanied by a non-exhaustive list of examples that frame the potential range of answers. The drafting provides for cover to be available where a person has a "work-related harm", which is defined as "a harm that has been caused by, triggered, exacerbated, or significantly contributed to, by the person's work." This test, discussed further in Chapter Eight has been drafted to widen the available causal connections, allowing for a broader range of evidence to be considered. "Harm" is defined to include “any injury, disease, medical condition (either physical or mental), or loss of or impairment of function". The proposed test is intended to cover any condition regardless of diagnostic categorisation where such a condition arises from the person's work. The test uses "the person's work" to indicate that the evaluation should be focussed on the individual and their "work" in the widest sense, rather than just the "physical environment",

\footnotetext{
${ }^{688}$ Section 3.
} 
"characteristics" or "tasks" that people in a given occupation are known to perform, as is the case in section 30. The term "work" is not defined in the proposed drafting, as discussed in the next chapter, but goes beyond the relationship of employment, and is generally understood to encompass more within it than just the tasks or physical environment where work takes place. "Work" in combination with the other drafting elements clearly extends to the social and cultural relationships of work and the manner of engagement to perform work or termination from it.

The definition of work-related harm is accompanied by a non-exhaustive list of the hazardous working conditions which may give rise to such a harm. The drafting of each of the items on the list is covered in greater detail in the next chapter; however, the function of the list in framing the causal narrative and the approach taken to designing the list is discussed here. The use of indicative lists in guiding interpretation is not unusual in the drafting of New Zealand legislation, with the courts using such lists to ascertain the meanings of undefined words and the intention of Parliament.

The indicative list is intended to form a key part of the new approach to causation, supporting the shift in focus from diagnostic category and medical ideas of causation, to the role of work and the objectives of improved health and safety. Unlike the approach in the current ACA, the list does not comprise a selection of indicative health problems which may be treated as work-related but rather a range of workplace hazards which may result in harm. The intention of the hazard-based framing is to focus the decision-maker's attention on work, escalating work-related factors in the minds of the decision-makers and in the resulting causal narratives.

For example, the list provides for harm that arises "from exposure to hazards in, or of, the physical environment, including buildings, structures, vehicles, plant, machinery, tools, objects, materials, or surfaces." This item would capture a large proportion of the "accidents" falling within the current definition of section 25. However, rather than focus on the "application of external force" localised to the body, it focuses on the physical working environment and the role of the hazards in the working environment in causing 
the harm and is potentially much wider in scope. This list also includes harms arising from "temperature, noise, vibration or radiation", "exposure to hazardous substances", and "exposure to infectious or pathogenic agents." This list would cover all of the current schedule-listed conditions but does not specify the diagnosis, or the substance, again shifting the focus from the disease and whether it has "occupational status," to the hazards that are present in the person's working environment. The drafting shifts the focus from the peculiarities of the diseased individual to the hazards of work.

The indicative list also provides cover to psychosocial hazards, including "the presence of, or interaction with, people within the working environment" covering bullying, harassment and occupational violence, "the performance of work or specific work tasks", "the organisation or arrangement of work, including times, hours, patterns or schedules, volumes or intensity of work" and harms as "a result of practices or processes used in the control or management of work (whether unreasonable or not), including the management of people and performance of work, or the manner or process of engagement to perform, or dismissal from work". These hazards are given equal status in the list to hazards associated with physical injury and make clear that unreasonable work-loads and unhealthy management practices are important hazards capable of causing harm.

The indicative list is intended to operate in the way described as an "anchoring heuristic" or "focalism" in the economics and psychology literature. ${ }^{689}$ An anchoring heuristic is a way of priming decision-making through the provision of an initial value, which is relied on as a starting point. While anchoring heuristic research has typically focussed on numerical values (e.g. a starting value influences subsequent offers and estimates), the effect can also be seen in the framing of causal narratives. Where a list of potential causes is provided in the legislation it creates a presumption that the health condition is created by one of those factors, and that the particular hazard is, or ought to be, treated as a cause, for the purpose of the legislation.

\footnotetext{
${ }^{689}$ See A Furnham and H C Boo "A literature review of the anchoring effect" (2011) 40(1) The Journal of Socio-Economics 35; and A Tversky and D Kahneman "Judgment under uncertainty: Heuristics and biases" (1974) 185 Science 1124.
} 
The anticipated effect is that decision-makers are influenced in the framing of specific causal questions and in the determination of which causal factors ought to be elevated to the status of cause. Essentially, in the mind of the decision-maker the condition's "cause" will be something "like one of these things" listed and the resulting statement of cause and effect framed in that language. It also potentially impacts on the type of evidence required, shifting from evaluation of competing diagnoses and medical opinions, to information about the hazards of the workplace and the potential health impacts.

It also impacts on the way in which data is collected, as resulting data is framed by the categories of cover, allowing for hazard-based ideas to inform the categories of data collection. For example, health care providers interacting with the scheme will need to (as they do now) fill in a form, which will likely involve questions such as: "is the condition work-related?" and "was the condition related to one of the categories below?", or "please describe how the condition was caused by, triggered, exacerbated or significantly contributed to by the person's work." The forms are used to determine entitlement under the Act, but they also frame the way in which health care providers describe the causal relationships between a worker's working conditions and health problems, impacting on the framing of the data collected and the resulting narratives that emerge through the data. This also impacts on the discussion that health care providers have with patients about their health conditions, creating an opportunity for workers to better understand the health impacts of their working conditions.

\section{G New terms framing the causal narrative}

The new terms have been drafted to influence the resulting causal narratives, and to aid the shift away from medical notions of causation. The drafting is provided in the next chapter, but one key proposed change in terminology is the shift from "accident" and "injury" to "harm". As advanced by theorists such as Ricoeur and Goldie, individuals understand experiences through the language framing them and the law has a particular impact on 
this. ${ }^{690}$ The language of the scheme impacts on people interacting with it and other areas of life, including health care, the operation of government agencies, and the management of workplaces.

As set out in Chapter Four, "accident" has a history of social and cultural meanings that undermine health and safety. The proposed use of "harm" attempts to create a linguistic shift in the social and political meanings attached to occupational injuries and illnesses. For example, the sentence "the worker had an accident" implies that an unexpected and unpredictable event occurred in which no one but the worker was involved. Accident portrays an individualised construction of events, divorced from its social, political or economic context. By contrast, the word "harm" exists in everyday use as both verb and noun. Harm can refer to a wide range of negative effects, or to an act inflicted on a person. The sentence "the worker was harmed" means both that the person suffered a negative consequence and also that the person the worker was working for harmed them. This could shift the language from "the worker had an accident" to "the worker was harmed" in everyday conversation operating to shift the focus of the listener to the role of the employer or PCBU in the harming of the worker.

While there is no requirement to show the employer or PCBU was at fault, the linguistic framing places greater emphasis on the role of the employer or PCBU in the worker's harm. One of the goals identified in Chapter Three, is ensuring the recognition of the "wrong" done to workers in failing to provide safe and healthy work. Shifting the language from "accident" to "harm" helps to highlight the role of the employer or PCBU in causing harm to the worker, reinforcing health and safety promotion and enforcement.

The new Act uses the word "injury" only in its medical sense, as part of the definition of "harm". In medicine, an injury is defined as "damage or wound of trauma, particularly as a result of external force." ${ }^{991}$ An injury in the medical sense would include falling off a

\footnotetext{
${ }^{690}$ Ricoeur above at $\mathrm{n} 620$, and Goldie above at $\mathrm{n} 619$.

691 "Injury" defined in Medical Dictionary Online (11 March 2018) <https://medicaldictionary.thefreedictionary.com/injury>
} 
ladder and breaking a leg at work, but not the development of depression or anxiety from workplace bullying. Injury in the medical sense is closer to "accident" as it is understood in section 25 of the ACA. There is also a general legal meaning for the word injury. According to Birk, the word "injury": ${ }^{692}$

... has become orientated to the victim, so much so that it no longer reveals whether the harm which the victim has suffered is attributable to another's wrong. But in Latin it was originally oriented the other way, inuria being formed from a negative particle in- combined with ius, iuris, the word for 'right' and 'law', and hence something done non iure (non-rightly).

What Birk is emphasising is that the term injury is conceptually shifting to be closer to the medical meaning of the word. An 'injury' in the traditional legal sense is a violation of a right or a breach of a duty. ${ }^{693}$ It can be distinguished from damage, which is "loss caused by injury." 694 While the historical legal use of the word would support the intended narrative, it is used less often than the medical terminology, even by lawyers, and might prove to be confusing as doctors interact more often with the scheme. Harm, by contrast, is an old English word that, as a noun, refers to pain, hurt, grief or sorrow. ${ }^{695}$ Harm is not a medical diagnosis, nor a category of such. It allows a wider range of consequences to fall within its ambit, including chronic diseases. Harm also has no legal meaning, operating in the case law only to describe factual events, essentially only as evidence required to establish "damage." Adoption of the term "harm" fits with the shift away from the bodyfocused and overly medicalised approach in the ACC provisions.

\section{Intended Operation}

The proposed new structure of the legislation, the framing of the Parts, the principle-based purpose sections, the drafting of the test with indicative list, and the new terminology is

\footnotetext{
$\overline{{ }^{692} \text { Peter Birks "The concept of a civil wrong" in David Owen (ed) Philosophical Foundations of Tort Law }}$ (Clarendon Press, Oxford, 1995), at 31.

${ }^{693}$ Above.

${ }^{694}$ Above.

695 "Harm" in Online Etymology Dictionary <https://www.etymonline.com/search?q=harm>
} 
intended to operate together to shift the focus of the legislation, and allow for the goal of improved work health and safety to be achieved.

\section{Diagram of Intended Operation}

- Worker presents to GP or other care provider with a workrelated health problem

- Health provider (in order to assess funding eligibility) asks worker about their job and its possible impacts on health questions on cause framed by claim form (based on legislative test) provide information on hazards

\section{Claim submitted}

- Form used to determine eligibility for cover. Most claims uncontroversial and cover provided.

- More difficult claims are sent for review and additional information requested.

- Information on claim form processed- data results

Claim referred

Claim referred to review panel who apply new causal test- informed by explicit purpose

Right to appeal- courts apply new causal testjudicial oversight informed bv explicit purpose

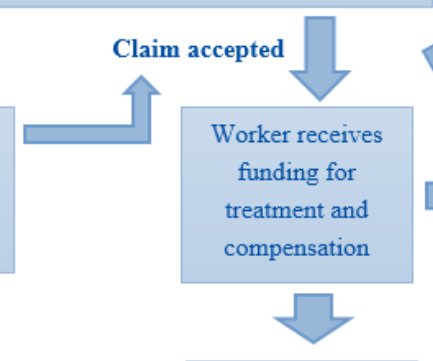

Worker accesses treatment and recovers

Worker returns to work
Discussion of impact of work on health

helps improve worker understanding

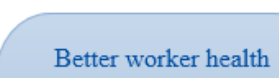
policy and enforcement.
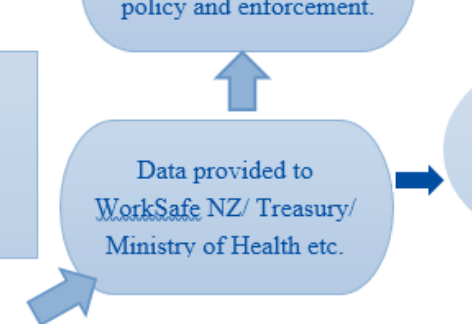

Unions able to obtain data and

use in organising/ bargaining

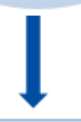

Employer/ PCBU notified of claim (including relevant

hazards)

Employer/ PCBU required to meet HSWA obligations

Employer/ PCBU required to accommodate return to work/ protection from adverse action
Employer/ PCBU action to prevent reoccurrence

\section{A Examples of operation}

To better understand the differences in the causal approach it is useful to see how the test would be applied in cases involving complex causal relationships in the "big three" diseases discussed in Chapter Five.

\section{Example: Worker C's heart attack}

Worker C suffers a heart attack and is now incapacitated from returning to work. Until the day of the heart attack Worker $\mathrm{C}$ worked as a bus driver, in a bus company which has been 
taken over by a series of companies winning successive contracts on the basis of cheaper operating costs and more efficient services with fewer delays. The bus company has introduced a management programme with pay linked to service delivery targets and punishments for delays. This has resulted in the drivers working under extremes of stress and a culture of bullying. Worker C's doctor considers his stress has contributed to his high blood pressure, sleep problems and metabolic syndrome which are common precursors in heart disease. Worker $\mathrm{C}$ is also overweight, seated all day with little exercise outside of work, and in order to unwind likes to drink with friends at a local burger bar. The evidence of Worker C's heart attack presents a complex pattern of risk factors, including early life deprivation, low income, a family history of heart attacks and unhealthy lifestyle choices. There is evidence to link Worker C's work stress to the heart attack, which occurred at the end of a particularly stressful shift (high blood pressure resulting in rupture of atherosclerotic plaques) but the relationship is not isolated or singular.

Applying the current legislation, worker $\mathrm{C}$ has not suffered an accident within the meaning of section 25, already marking his condition as an "exception" to what ought to be compensated. Worker $\mathrm{C}$ is then excluded from section 30, cover for "gradual process, disease or infection" as the condition is the result of "non-physical stress." The presence of this exclusion signalling that "non-physical stress" is to be treated differently and is perhaps less worthy of compensation. Even without this specific exclusion Worker C would fail to meet the test in section 30 , either struggling to prove the condition was more likely for those performing driving tasks or in public transport environments (although there is some epidemiological evidence to support this), or struggling to prove his cardiovascular disease was "caused" by the tasks or environment, given the complex and interrelated factors present in the development of cardiovascular diseases. Heart attacks are only covered under section 28(3), but applying the case law, even if a particularly triggering bout of physical exertion could be found, the medical evidence would show the heart attack could not have occurred without an underlying history of heart disease and Worker $\mathrm{C}$ would not be eligible for compensation. 
Under the proposed new test, Worker C would first need to show that he was a "worker", which a bus company employee is, and then next that his condition was related to his work, immediately drawing the decision-maker's attention to his work and what had occurred in his work prior to the heart attack. Based on the facts above, Worker $\mathrm{C}$ could show workstress was a "trigger" or "significant contributor" to his heart attack, although not the sole cause. A heart attack would meet the definition of "harm," as would the pre-existing cardiovascular disease and high blood pressure. The evidence required would include information on the hazards of Worker C's work, including "the organisation and arrangement of work" "interactions with others" and "hours or intensity," with the claim form (or subsequent information in review process) able to describe the factors at play, such as stressful working conditions and culture, workload and intensity and job design factors.

The indicative list starts to frame the causal questions in such a way that favours work factors being elevated in the causal narrative. The question is then, in light of the explicit purpose to compensate workers and improve health and safety, was Worker C's heart attack "triggered by" work, or his underlying heart disease "exacerbated by", or "significantly contributed to", by the stress associated with the arrangements of work, hours and intensity and exposure to people. The causal story for Worker C's heart attack, shifts in focus to the contribution of work. In interpreting this array of causal factors, the decision-maker must determine the relative weights to be given to the causal factors. If the causal question is framed to favour immediate cause, medical evidence or epidemiological patterns, then Worker $\mathrm{C}$ would likely be denied cover. If the clear purpose of the test is to address the health consequences of work, then the cause for the purpose of the cover provisions would likely favour Work C having cover.

Additionally, as harm includes not only "cardiovascular events" but a wider range of potential health conditions, Worker C's preceding cardiovascular disease, and associated high blood pressure, sleep problems and metabolic syndrome could be eligible for ACC cover. Worker C's doctor would be able to claim for ACC cover earlier in the progression of Worker C's health problems, allowing Worker C to access ACC funded treatments and 
interventions, potentially preventing (or at least delaying) the heart attack and reducing the resulting incapacitation. Worker C's doctor would also be able to discuss the impact of work stress on Worker C's condition, and/or provide a medical opinion, potentially helping Worker $\mathrm{C}$, other drivers, or their union to strengthen claims for improvements to working conditions. The previous recognition of Worker C's health problems and the alerting of the bus company to them being "work-related" potentially also creates an incentive for addressing the problems earlier, to avoid possible enforcement action.

\section{Example: Worker D's severe depression}

Worker D works as an emergency department nurse in a busy public hospital. The emergency department has been underfunded by successive governments, with known problems of understaffing and under-resourcing. The nurses work 12-hour rostered and rotating shifts. The work is very stressful, with nurses exposed to frequent traumatic incidents and violence. The culture of the emergency department is also known for bullying and difficult relationships between nursing and medical staff. Worker D has three young children, one of whom has serious autism and requires additional care. Worker D and her husband are also having difficulties in their marriage, exacerbated by the pressures of Worker D's shift patterns and stress levels and the demands of caring for a disabled child. Worker $\mathrm{D}$ is diagnosed with severe depression and will be unable to return to work for several months. The evidence of Worker D's health problems discloses a range of potential factors, including genetic susceptibility, the experience of depression as a teenager, and prolonged stress and sleeping problems.

At present Worker D falls outside of "accident" in section 25. She also falls outside the single incident trauma provisions in section $21 \mathrm{~B}$, as her condition has not resulted from a single "one-off event" that results in the "more or less immediate" onset of PTSD. ${ }^{696}$ Worker D would be excluded under section 30(5) for a mental health problem caused by

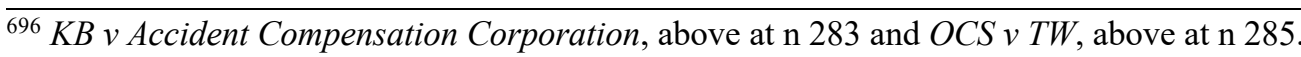


non-physical stress, and even if not, would struggle to show that stress or care-related exhaustion did not exist to any material extent outside of her workplace.

If applying for compensation under the proposed new provisions, Worker $\mathrm{D}$ is first required to show she is a "worker", which a nurse is, and then that she has suffered a "harm," with depression meeting the definition of "medical condition". She would then either need to show her work "was a significant cause of her depression", or that her depression was "exacerbated or triggered" by her work. Worker D may, on the evidence, be able to show that her work was a "significant cause" of her depression, with the evidence framed by the non-exhaustive list focusing the mind of the decision-maker on the hazards of people in the workplace, and the hours or intensity of her work, or its arrangement and organisation. Alternatively, given the prior history of depression and outside of work factors, Worker D may be able to show that her work triggered or exacerbated her depression. In interpreting this test, the purpose section becomes relevant with the explicit purposes to recognise Worker D's rights, ensure her full participation in economic and social life, improve health and safety and ensure greater equity in compensation tipping the balance in her favour.

As above, Worker $\mathrm{D}$ would potentially have had an interaction with her doctor prior to the depression reaching the level of severe incapacitation in the scenario. Worker D's doctor would potentially apply for ACC cover earlier, allowing for time-off to recover, ACC funded medication and psychotherapy to be put in place earlier, potentially allowing for a better medical intervention. ACC cover would alert Worker D's employer to the need for return-to-work planning and the work-related contribution to the problem, ideally resulting in improvements at work. Worker D's employer may well be seeing patterns in ACC claims emerging, which can be used internally or externally in discussions of resourcing with the Distract Health Board or government funding agencies. Patterns in ACC claims may also help Worker D's union in their claims for action by the employer or the government. 
Worker $\mathrm{E}$ is contracted to perform data processing work from her home laptop for a range of different organisations. Worker $\mathrm{E}$ is provided work through an online intermediary, with jobs ranging in size from a few hours to a few weeks' worth of work. The price and deadline for each job is set by the advertiser using the online platform. Worker $\mathrm{E}$ is matched with different advertised jobs based on her skill profile. Job allocation is done by algorithm. Worker E must complete the job within the time allocated or will not be paid. If Worker $\mathrm{E}$ fails to complete a job or refuses too many matched jobs her star rating declines and she will receive fewer offers. Worker E presents to her doctor with wrist, shoulder, back and neck pain, which her doctor attributes to sitting hunched over a laptop at her kitchen table for long hours, taking few breaks and working with prolonged stress-related physical tension. Worker $\mathrm{E}$ is experiencing a great deal of nerve pain, although medical examination and $\mathrm{x}$-rays reveal no obvious physical injury. Worker $\mathrm{E}$ is diagnosed with idiopathic pain and pain syndrome. The evidence suggests some history of back pain, either associated with previous injuries and aging-related deterioration and some prior history of mental health problems, which may be affecting her experience of pain. Worker $\mathrm{E}$ also uses her laptop for non-work tasks like email, web browsing and watching movies.

Applying the current law, Worker E would fall outside the definition of accident in section 25. Worker E would likely fail to meet the test in section 30, as, following the decisions in Teen and Meikle ${ }^{697}$ her condition is considered to be the result of "non-physical stress" and pain syndromes are considered "mental." Worker E would also fall outside section 28B.

Applying the proposed test, Worker E would need to show she was a worker, which although she is not an employee, she would be able to do. Using the HSWA definition, Worker E "performs work in any capacity" for a PCBU. It would not be necessary to determine whether the PCBU was Worker E, the online intermediary, or the advertising

${ }^{697}$ Teen v Accident Compensation Corporation and Telecom Ltd and Meikle v Accident Compensation Corporation, above at n 259. 
business, or a combination of each. Worker $\mathrm{E}$ would then need to show her pain condition meets the definition of harm, which it would, as a pain syndrome is a diagnosable medical condition, and regardless of whether it is better characterised as mental or physical, meets the definition of an illness. Worker E would then need to show the harm she suffered was "caused by, triggered, exacerbated or substantially contributed to" by her work, her work being the completion of data processing tasks through the online intermediary platform.

While the precise mechanistic cause of pain syndrome is not known, it is believed to be the misfiring of nerve signals within a nerve, typically with some mental or physical trigger, which can include acute injury, or repeated or prolonged physical strain. The available medical evidence would likely fit more easily within "triggered" "exacerbated" or "substantially contributed to," especially when considering the framing of the nonexhaustive list. Work-related harm includes "harm through the performance of work or specific work tasks" and "the organisation or arrangement of work, including times, hours, patterns or schedules, volumes or intensity of work." The evidence available would likely indicate a sufficient link between Worker E's condition and the tasks (data processing on a laptop), associated ergonomic strain and prolonged activity under conditions of stress, as well as the high volumes and intensity of work. Given the explicit aims of compensation, the new test would likely favour the cover of Worker E's condition.

\section{Achieving the Labour Law Goals Set}

The proposed new Act has been designed to address the problems identified in Chapter Four and allow for a better response to health conditions with more complex relationships to work. The proposed reforms are also intended to achieve the labour law goals set in Chapter Three. The achievement of these goals is discussed below.

\section{A Addressing the inequalities of bargaining power}

The classic aim of labour law is to address the inherent inequalities in bargaining power between workers and those that control work. As discussed in greater detail in Chapter 218 
Three, the unequal power relations of work have a significant impact on work-related injury and illness, with employers/PCBUs having the power to determine the work, who is performing it, and with what training and resources. While the reforms proposed obviously will not eliminate the unequal power relations inherent in capitalism, they can go some way towards improving the bargaining power of workers in relation to health and safety.

Bargaining power is typically thought to be improved through law reform, either where the law increases the bargaining position of workers or imposes an independent third-party regulator to enforce standards. The reforms proposed seek to have an impact through both means. First, providing ACC cover to all work-related health problems makes it easier for individual workers to obtain compensation. As discussed in Chapter Four, the current law forces many workers to sue to obtain compensation for their work-related health problems using the personal grievance regime with the attendant costs and evidential difficulties of doing so. Inequalities in bargaining power are played out in the parties' abilities to access justice, with individual workers generally having fewer resources to take legal claims, and the current system encouraging confidential mediated settlements. Further, as unions frequently take these cases on behalf of their members, bearing the legal costs of doing so, having easier access to ACC cover for all work-related health conditions frees up union resources, which could be spent elsewhere.

Second, the reforms proposed would see the data collected on work-related injuries and illnesses improved, improving the visibility of currently excluded work-related health problems. The data collected under the new Act is framed by the cover test and the indicative list, which requires information about the hazards in the workplace, potentially improving the quality and usability of data for health and safety prevention research, policy development and the establishment of enforcement priorities. This richer and more comprehensive data strengthens union claims for government intervention, regulator action, and the employer adoption of new practices. 
Recent strike action in New Zealand involving the nurses, teachers and junior doctors have seen the framing of claims in collective bargaining as health and safety issues. ${ }^{698}$ For example, narratives of stress-related illnesses were used to support claims for rostering change in the case of the junior doctors, minimum staffing levels for the nurses, and workload provisions for the teachers. ACC derived data on the number and costs of claims within a given industry allows for evidence of the impacts of current working conditions and support for workplace action and improvements. This potentially strengthens the individual and collective bargaining position of workers in relation to hazardous working conditions. Publicly available data on the health conditions resulting from work also enables greater pressure to be put on governments to ensure greater work health and safety regulation and enforcement action.

Doctors, physiotherapists, counsellors and other health care providers are able to access treatment funding for patients with conditions covered by the scheme, and as a result are potentially more likely to frame conditions where work is a contributor as "work-related" so patients can continue to afford to obtain treatment and also take paid time-off to recover. This has a positive consequence for the worker (enabling earlier intervention), the data (allowing for more information on a wider range of work-related conditions to be captured), and on workplace health and safety. The new Act should drive healthcare providers to ask about working hazards and conditions of work and discuss the possible health conditions resulting, allowing for the worker to better understand the potential impacts of their work on their health, and possible options for addressing the issues. It may even increase health provider interest in work-related health issues and research. The provision of a medical certificate describing a health problem as "work-related" may also have an impact. A medical certificate is potential evidence of a failure of an employer or PCBU to "take all

\footnotetext{
${ }^{698}$ See No author "junior doctors strike for working conditions, not money- doctor" (29 April 2019) NewstalkZB <https://www.newstalkzb.co.nz/on-air/mike-hosking-breakfast/audio/junior-doctors-strikeabout-working-conditions-not-money-doctor/>; Damian George "Teachers vote to stage largest-ever strike as negotiations with ministry stall" (13 May 2019) Stuff

$<$ www.stuff.co.nz/national/education/112655087/teachers-have-voted-to-strike-on-may-29>; The Press "Nurses' strike over staffing levels, pay and priorities" (13 July 2018) Stuff $<$ https://www.stuff.co.nz/thepress/opinion/105435924/nurses-strike-over-staffing-levels-pay-and-priorities>
} 
reasonably practicable steps" to address a health and safety issue when it was brought to their attention.

\section{B Recognising the "wrongs" of poor health and safety}

As discussed above, the new Act aims to reframe work-related injury and illness as a "harm" done to workers performing hazardous work, rather than an "accident" like any other. In addition to the intended linguistic shift, the proposed reforms widen the scope of what is considered "work-related" impacting on the scope of the employer or PCBU's duties under section 36 of the HSWA. As discussed in Chapter Three, the broadly drafted duty to "take all reasonably practicable steps" is informed by societal and industry norms, public and political recognition of the risks and the priorities of the regulator. The new Act widens the range of what is considered to be "work-related", and accordingly what is considered to be within the scope of employer or PCBU's responsibilities. Although psychosocial hazards are covered by the HSWA, these often end up neglected by the regulator, which lacks the enforcement tools, resources or political backing to respond to these hazards. Workers have also typically lacked the evidence, regulator support or bargaining power to require an employer or PCBU to take actions relating to job design, the organisation and arrangement of work, or on matters such as job size, intensity or staffing levels. The proposed reforms help to improve the visibility of health conditions arising from such hazards enabling evidence and supporting regulator enforcement action.

\section{Recognising the rights of workers}

As discussed above, the explicit reference to the rights of workers in the purpose section for the Work-Related Harm Part is intended to create a link to the relevant rights instruments and the associated jurisprudence. This creates a clear association between the compensation provided and the rights of workers to compensation and improved health and safety. The right to health and safety is supported by the drafting in a number of ways, and this is discussed further in the next chapter. 


\section{Dignity and equity for workers}

The new cover test, the removal of the mind/body distinction and the framing of psychosocial hazards as equivalent to physical-injury-causing hazards, helps to ensure that workers in newer and female-dominated occupations currently excluded from ACC can access treatment, compensation, rehabilitation and support. The wider definition of harm and purposive framing of the causal test also allows for a wider range of evidence to be presented, including alternative cultural concepts of stress and disease. The new test may provide for differently framed research in to the relationships between work and health for Māori to be considered and accepted. Dignity is discussed further in the next chapter, but is enhanced where there is fair access to adequate treatment, earnings-related compensation, rehabilitation and support, as well as safe and healthy conditions of work.

\section{$V$ Conclusion}

This chapter has proposed a new Act to replace the current ACA and improve the coverage of work-related injuries and illnesses and work health and safety. The new Act groups all work-related harm provisions within one new legislative Part, with an explicit purpose section to guide the decision-makers approach to causation. The new purpose section reflects the labour law theoretical framework, with an explicit mandate to consider the rights of workers, achieve comprehensive, fair and equitable cover, ensure workers are treated with dignity and contribute to the improvement of work health and safety. The purposive approach is then supported by the selection of terms which enable a shift in focus

in the resulting causal narratives. The drafting of each of these features is provided and explained in the next chapter. 


\title{
CHAPTER EIGHT: THE PROPOSED NEW ACT
}

\author{
Drafting for the Proposed New Cover Provisions
}

\section{Introduction}

The aim of this thesis was to develop a proposal to reform the cover of work-related health problems in New Zealand. The goals were to ensure fairer and more equitable cover, enabling the scheme to better respond to changes in work and medical thinking, and improve work health and safety. The previous chapter outlined the approach of the reforms and proposed a new Act. This chapter goes into further detail proposing the drafting for the new Work-Related Harm Part. This chapter provides the draft provisions and then explains each in greater detail, discussing intended interpretation and operation. There have been calls for the Government to enact the full Woodhouse Report visions of a comprehensive social insurance scheme. ${ }^{699}$ While the Minister has indicated such wide-reaching reforms are unlikely in the current or next term, ${ }^{700}$ the new Act presented in the previous chapter would allow for future expansion. Further, the drafting presented could easily be adapted should recommendations for an independent ombudsman or altered processes of review be accepted..$^{701}$

\footnotetext{
${ }^{699}$ Palmer, above at $\mathrm{n} 13$ and Forster, above at n 14.

${ }^{700}$ Cate Broughton "OECD report calls for extension of ACC" (13 Dec 2018)

$<$ www.stuff.co.nz/national/health/109313061/oecd-report-calls-for-extension-to-acc >

${ }^{701}$ Forster, Barraclough and Mijatov, above at n 9.
} 


\section{Proposed Drafting}

Set out below is the proposed drafting. Each of the terms is then explained further below.

\section{Part 2 Work-Related Harm}

\section{Interpretation [for Part 2]}

harm includes death or any injury, disease, medical condition (either physical or mental), or loss of, or impairment of, function worker has the same meaning as in the Health and Safety at Work Act 2015 ( a worker means an individual who carries out work in any capacity) working environment includes workplace, and any physical, social, cultural or psychological characteristics of that workplace, including any substances or organisms with in it

workplace has the same meaning as in the Health and Safety at Work Act 2015 (a place where work is being carried out, or is customarily carried out, for a business or undertaking and includes any place where a worker goes, or is likely to be, while at work)

\section{Purpose [for Part 2]}

(1) The purpose of this Part is to:

(a) Recognise the rights of workers harmed through work;

(b) Provide for the comprehensive, fair and equitable compensation of workrelated harm;

(c) Ensure those who have suffered a work-related harm are able to return, to the fullest extent possible, to health, dignity and the ability to participate in economic, social, cultural and family life;

(d) Contribute to the improvement of health and safety in New Zealand workplaces, including through the collection of comprehensive statistics on work-related harm. 


\section{Cover for Work-Related Harm}

(1) A person has cover if they have suffered a work-related harm.

(2) A work-related harm is a harm that has been caused by, triggered, exacerbated, or significantly contributed to, by the person's work.

(3) For the purpose of subsection (2) work-related harm includes, but is not limited to, harm that arises:

(a) from exposure to hazards in, or of, the physical environment, including buildings, structures, vehicles, plant, machinery, tools, objects, materials, or surfaces;

(b) from exposure to temperature, radiation, noise or vibration in the working environment;

(c) from exposure to hazardous substances in the working environment;

(d) from exposure to infectious or pathogenic agents in the working environment;

(e) through the presence of, or interaction with, animals, birds, fish, reptiles, insects or other creatures, dead or alive, and including parts of, or products made from, in the working environment;

(f) through the presence of, or interaction with, people in the working environment (be they permitted in the working environment or otherwise), including bullying, harassment or violence;

(g) through the performance of work or specific work tasks;

(h) as a result of the organisation or arrangement of work, including times, hours, patterns or schedules, volumes or intensity of work (whether unreasonable or not);

(i) as a result of practices or processes used in the control or management of work (whether unreasonable or not), including the management of people and performance of work, or the manner or process of engagement to perform work, or dismissal from work. 


\section{Cover for Third Parties Harmed through a Transmitting Worker}

(1) Cover is available where a person suffers a harm through a transmitting worker.

(2) Harm through a transmitting worker means a harm that has been acquired through contact with a worker, and includes harm:

(a) through contact with worker garments, tools or equipment capable of transmitting a source of harm; or

(b) transmitted by the worker through an infectious agent; or

(c) transmitted to offspring via in-utero exposure, infected breastmilk or inherited through affected genetic material.

\section{Review Panel on Work-Related Harm}

(1) The functions of the Work-Related Harm Review Panel are to:

(a) Review work-related harm claims that are complex or novel, and make a determination of cover that is consistent with the purposes of this Part;

(b) Provide written reasons for the decision to the claimant;

(c) Compile and make publicly available (in an anonymised form) determinations of work-related harm decisions;

(d) Consider work-related harm trends and provide appropriate guidance or recommendations to the Minister on relevant matters;

(e) Provide information and guidance to WorkSafe New Zealand and other agencies on work-related harm trends and other relevant matters. 


\section{Explanation of Proposed Drafting}

\section{A Proposed "Interpretation" section}

As discussed in the previous chapter, the new terms are intended not only to expand and update the coverage provisions, allowing a wider range of working practices and health conditions to be covered, but also create a linguistic and culture change, shifting the emphasis from the individual and specific diagnosis to the wider conditions of work and the policy goals of improved health and safety.

\section{B A shift from "accident" to "harm"}

"harm includes death or any injury, disease, medical condition (either physical or mental), or loss of, or impairment of, function"

As previously discussed, the proposal removes "accident" with its associated social and cultural meanings and replace it with the term "harm." Harm has a wider meaning than "injury" or "accident", which are terms with a long history of use in compensation schemes. ${ }^{702}$ "Harm" is used to capture a wide range of negative health consequences and is not a term with a pre-existing legal or medical meaning. Harm is in common use as a noun, defined as "physical or mental damage" 703 or "[p]hysical injury especially that which is deliberately inflicted, material damage or actual or potential ill effects or danger." ${ }^{~} 704$ It also operates as a verb and means "to damage or injure physically or mentally" 705 or "physically injure, damage the health of, or have an adverse effect on."706 As discussed in

\footnotetext{
${ }^{702}$ See the discussion of the history of these terms in Federal Court of Australia in May v Military Rehabilitation and Compensation Commission [2015] FCAFC 93.

703 "Harm" Merriam Webster Dictionary (25 Jan 2019)<https://www.merriamwebster.com/dictionary/harm>

704 "Harm" Oxford Dictionaries (25 Jan 19) <https://en.oxforddictionaries.com/definition/harm>

705 "Harm" Merriam Webster Dictionary (25 Jan 2019) <https://www.merriamwebster.com/dictionary/harm>

706 "Harm" Oxford Dictionaries (25 Jan 19) <https://en.oxforddictionaries.com/definition/harm>
} 
the previous chapter, selecting a term with this double meaning is deliberate and serves to frame the resulting narrative. Each of the terms used in the definition of "harm" is discussed below.

\section{a. "injury"}

The word "injury" is used within the definition of "harm" to denote its medical meaning. The use of the word "injury" as part of a list of consequences that may fall within the definition of "harm" is unlikely to prove confusing, even with the different medical, legal, and prior ACC uses. The meaning of the word, given its context, would likely be given its medical meaning, but, even if interpreted more widely, would not be inconsistent with the intended meaning to be given to "harm" when used in that sentence. Looking to the case law, the definition of "injury" has been given a recent and thorough analysis by the Full Federal Court of Australia in May $v$ Military Rehabilitation and Compensation Commission, ${ }^{707}$ and then on Appeal to the High Court of Australia. ${ }^{708}$ The Federal Court of Australia helpfully undertook an exhaustive review of the definition of "injury" in legislation and legal authority dating from the Workmen's Compensation Act 1897 (UK). The High Court in May reaffirmed the earlier decision in Kennedy Cleaning Services $v$ Petkoska, ${ }^{709}$ with Gleeson CJ and Kirby J stating that if: ${ }^{710}$

something... can be described as a sudden and ascertainable or dramatic physiological change or disturbance of the normal physiological state, it may qualify for characterisation as an 'injury' in the primary sense of that word

The Australian case law above has not been judicially considered in New Zealand but discloses the likely range of meanings that the word may come to bear.

\footnotetext{
${ }^{707}$ Above, at $\mathrm{n} 702$.

${ }^{708}$ Military Rehabilitation and Compensation Commission v May [2016] HCA 19.

709 [2000] HCA 45.

${ }^{710}$ At [39]. 


\section{b. "disease"}

While "disease" is a term used in medicine, its definition is wide and amorphous, operating more as an efficient concept, than as a concrete definition. There has been some medical commentary on the use of the word "disease", 711 with academics concluding that "we would at least all know [one] when we saw one., ${ }^{, 712}$ Scully states that: ${ }^{713}$

What counts as a disease also changes over historical time, partly as a result of increasing expectations of health, partly due to changes in diagnostic ability, but mostly for a mixture of social and economic reasons.

Some have attempted to define "disease" as the absence of health, although this is not without problems as it first requires a definition of "health". The WHO, however, defines "health" as "a state of complete physical, mental and social well-being, not merely the absence of disease or infirmity." 714 The WHO definition has been praised for embracing a holistic viewpoint, and equally condemned for being "wildly utopian." ${ }^{.715}$ This lack of precise medical definition makes the word "disease" ideal for use in the proposed new Act, as it contains enough certainty in meaning to be clear to medical professionals, and enough latitude to adapt to shifts in medical thinking.

"Disease" is also a word in common use. It is defined in the Oxford Dictionary as a: ${ }^{716}$

A disorder of structure or function in a human, animal, or plant, especially one that produces specific symptoms or that affects a specific location and is not simply a direct result of physical injury.

It is similarly defined in the Cambridge and Miriam Webster dictionaries as an "illness of people, animals, plants, etc., caused by infection or a failure of health rather than by an

\footnotetext{
711 Jackie Leach Scully "What is a disease?" (2004) 5(7) Science and Society 650.

${ }^{712}$ Scully, above, at 50.

${ }^{713}$ Above.

${ }^{714}$ WHO Preamble to the Constitution of the World Health Organization (WHO, New York, 1946).

${ }^{715}$ See RP Hudson The Cambridge World History of Disease (Cambridge University Press, Cambridge, 1993).

716 "Disease" in Oxford Dictionary online (29 Dec 2018)

$<$ https://en.oxforddictionaries.com/definition/disease>
} 
accident"717 and "a condition of the living animal or plant body or of one of its parts that impairs normal functioning and is typically manifested by distinguishing signs and symptoms."718 The common meaning is helpfully similar to the medical use of the term.

"Disease" is not defined in New Zealand or common law jurisdiction legal dictionaries and has no agreed legal meaning determined by case law. The word "disease" is referred to in the Health Act 1956 and some regulatory instruments, but without a provided definition. ${ }^{719}$ "Health" is also referred to in legislation, with the HSWA defining it only as "means physical and mental health." 720 This lack of precise medical definition and relatively consistent common meaning makes it useful for drafting, as it lends itself to a wide legal interpretation, and is able to vary as medical thinking develops over time.

\section{b. "medical condition (either physical or mental)"}

"Condition" is commonly defined as "the state of something with regard to its appearance, quality, or working order" and includes a "person's or animal's state of health or physical fitness" and an "illness or other medical problem". 721 "Medical condition" is defined in a medical dictionary as: ${ }^{722}$

disease, illness or injury; any physiologic, mental or psychological condition or disorder (e.g., orthopaedic; visual, speech or hearing impairments; cerebral palsy; epilepsy; muscular dystrophy; multiple sclerosis; cancer; coronary artery disease; diabetes; mental retardation; emotional or mental illness; specific learning disabilities; HIV disease; TB; drug addiction; alcoholism). A biological or psychological state which is within the range of normal human variation is not a medical condition.

\footnotetext{
717 "Disease" in Cambridge Dictionary online (29 Dec 2018) $<$ https://dictionary.cambridge.org/dictionary/english/disease $>$

718 "Disease" in Miriam Webster Dictionary online (29 Dec 2018) <https://www.merriamwebster.com/dictionary/disease>

${ }^{719}$ Health Act 1956, s 87A, "notifiable infectious disease"; See also Health (Diseases Communicated by Animals) Regulations 1965 and the Health (Infectious and Notifiable Diseases) Regulations 2016.

${ }^{720}$ HSWA, s16.

721 “Condition” in Oxford Dictionary online (29 Dec 2018)

$<$ https://en.oxforddictionaries.com/definition/condition>

${ }^{722}$ Medical Dictionary Online (29 Dec 2018) <https://medicaldictionary.thefreedictionary.com/medical+condition $>$
} 
This suggests that a "medical condition" is any state of being that medical science regards as not being "within the range of normal human variation". The words "either physical or mental" have been used in the proposed drafting to make it clear that mental conditions are included. As discussed above in Chapter Four, the line between mental and physical illness is an outdated and fictional one. The inclusion of "either physical or mental" is intended to make clear that the definition departs from the prior treatment of such conditions under the ACA. This was also done in the HSWA for the same reason. ${ }^{723}$

\section{c. "loss of, or impairment of, function"}

The phrase "loss or impairment of bodily function" has a long history of use in New Zealand and other common law jurisdictions, and was included in the former HSEA Schedule $1 .{ }^{724}$ The word "bodily" is deliberately absent from the drafting proposed for the new Act. This is intended to widen the range of functions that may be lost or impaired, including mental, neurological, psychological or social functions, as well as endocrine or immune functions, or sexual and reproductive functions. Due to the previous drafting, case law has tended to focus only on "loss of function" in relation to the physical function of a given body part e.g. a knee or elbow. ${ }^{725}$ The exclusion of the word "bodily" is an indicator that "function" ought to be given a wider reading than under previous legislation.

The identified medical uses of "loss of function" are mostly practical and descriptive, implying broadly that something does not work as it should. Technically, "loss of function" refers to a specific type of genetic mutation. ${ }^{726}$ It is unlikely that either current medical use

\footnotetext{
${ }^{723}$ HSWA, s16.

${ }^{724}$ Term used in the Accident Compensation Act 1982 and discussed in case law dating from the mid1980s, including Appleby v Accident Compensation Corporation [1985] NZACAA 3 and Kiney v Accident Compensation Corporation [1990] NZACAA 253.

${ }^{725}$ See recent use of the term in Hill v Accident Compensation Corporation [2016] NZACC 229; Brooker v Accident Compensation Corporation [2016] NZACC 186; Yeoman v Accident Compensation Corporation [2008] NZACC 191; Slayman v Accident Compensation Corporation [2013] NZACC 236.

726 "Mutant types" in A F Griffiths, J H Miller, D T Suzuki An Introduction to Genetic Analysis (7th ed. Freeman, New York, 2000) <https://www.ncbi.nlm.nih.gov/books/NBK22011/>
} 
of the term will prove confusing. Read as part of a definition of "harm" and in light of the express purpose provided for the new Part, the proposed drafting should result in a substantial widening of available cover. Shifting the drafting from "bodily function" to any function of the worker that may be lost or impaired through the performance of hazardous work, also helps to shift the narrative away from "accident," and to the worker (as a whole human being) and the conditions of their work.

\section{A shift from "employee" to "worker"}

worker has the same meaning as in the Health and Safety at Work Act 2015 (a worker means an individual who carries out work in any capacity)

The proposed drafting moves from "employee" and "self-employed" as in the current ACA, to "worker." Section 19 of the HSWA defines a "worker" as "an individual who carries out work in any capacity for a PCBU" and expressly includes those working as an employee, contractor, subcontractor, employee of a labour hire company, outworker, apprentice, trainee, a person gaining work experience or undertaking a work trial, or a volunteer worker. The use of the HSWA definition of "worker" is intended to ensure cover to anyone performing work however they may be described. Adopting an expanded definition of "worker" is consistent with the goal of achieving alignment between the compensation and health and safety legislation and the theoretical approach underpinning the proposal.

The shift from "employee" to "worker" in the Australian and New Zealand health and safety legislation was done to "cover new and evolving work arrangements and extend the duty beyond the traditional employer and employee relationship."727 The HSWA was based on the Australian Model Law, which followed a process of development and consultation from 2007, including two Parliamentary Committee Reports. The Committee, in developing the model was clear that "the model Act provide for... as broad a coverage as

${ }^{727}$ Commonwealth of Australia, above at n 337, at xxii. 
possible, to ensure that the duties of care deal with emerging and future hazards and risks and changes to work and work arrangements". ${ }^{728}$ The Report recognised that "the work environment, arrangements and activities of 2008 are fundamentally different from those of 25 years ago, when the early Robens-style OHS legislation was first introduced in Australia." ${ }^{\prime 29}$ The Report highlighted the growth in casual, part-time and temporary work, outsourcing, job-sharing and the use of labour hire companies and home workers, as well as the rising numbers of small businesses (those with less than 20 employees) and microbusinesses (those with less than five employees). The Report acknowledged that these factors are "challenging many of the principles underpinning the Robens model, which had assumed relatively stable, permanent work arrangements between employers and employees." "730 The HSWA definition of "worker" was developed as a response to such challenges and invites interpretations of the proposed drafting that are consistent with this intention.

The ACA uses the definition of "employee" in the Income Tax Act 2007. This choice of definition seems to be primarily for administrative convenience, allowing levies to be more easily collected by IR (formerly New Zealand's Inland Revenue Department). The expanded definition may result in some issues in the collection of levies from those who fall within the grey space between employee and self-employed, although this is a problem which already exists in New Zealand and internationally, and which IR and other agencies are seeking to remedy. ${ }^{731}$ Even if there are some issues with levy collection it is particularly important to ensure that the workers who are most likely to fall within these gaps have access to compensation (even if a shortfall requires some contribution via Vote Health as an interim measure). Ensuring there is cover for workers in peripheral or precarious segments of the labour market is essential for ensuring both equity in access and also improved health and safety.

\footnotetext{
${ }^{728}$ Above, at xxii.

${ }^{729}$ Above, at 8 .

${ }^{730}$ Above.

${ }^{731}$ See discussion in New Zealand Tax Working Group "The future of work: Sustaining the tax system" (IRD and Treasury, April 2018); See also Anna Milanez "The taxation of non-standard work" (OECD, November 2018).
} 
As set out in Chapter Four, New Zealand and international research has highlighted that workers engaged in precarious modes of working are more likely to be injured or die, more likely to suffer from occupational diseases, have poorer mental health and poorer health outcomes generally. For example, NOHSAC Technical Report 10 concluded that "employees in casual and precarious work are far more susceptible to workplace injury than those in full-time fixed positions." "732 The Independent Taskforce Report and the NZCTU Report, also highlighted the increased vulnerability of this group and the need for specific attention. ${ }^{733}$ The proposed definitions are drafted to ensure that all workers, regardless of the specific nature of their engagement, are equally able to benefit from the new Act proposed.

\section{D "Workplace" and "working environment"}

"Workplace" and "working environment" are also terms intended to cover a wider variety of working situations, recognising the shifts taking place in the nature of work and the manner by which people are engaged to perform it.

workplace has the same meaning as in the Health and Safety at Work Act 2015 (a place where work is being carried out, or is customarily carried out, for a business or undertaking and includes any place where a worker goes, or is likely to be, while at work)

working environment includes workplace, and any physical, social, cultural or psychological characteristics of that workplace, and any substances or organisms within it

\footnotetext{
${ }_{732}$ Philip Bohle, John Buchanan, Tony Cooke, Gillian Considine, Michelle Jakubauskas, Michael Quinlan, Michael Rafferty and Rose Ryan The Evolving Workplace Environment in New Zealand: Implications for Occupational Health and Safety (NOHSAC Technical Report 10) (NOHSAC, Wellington, 2008), at 6.

${ }^{733}$ Independent Taskforce above at n 32, NZCTU, above at n 452.
} 


\section{a. "Workplace"}

"Workplace" is given the same meaning as in the HSWA. The HSWA provides that workplace "means a place where work is being carried out, or is customarily carried out, for a business or undertaking" and "includes any place where a worker goes, or is likely to be, while at work." 734 The definition specifically includes "a vehicle, vessel, aircraft, ship, or other mobile structure" and "any waters and any installation on land, on the bed of any waters, or floating on any waters." "Workplace" as defined in the HSWA is not confined to a specific physical location, ending at the factory gates, but rather refers to any place the worker is, or goes, while at work. The Explanatory Memorandum for the Model Work Health and Safety Bill explains that there is "no requirement for an immediate temporal connection" because "the main object of the Bill is to secure the health and safety of workers at work as well as others who are in the vicinity of a workplace." ${ }^{" 735}$ It states that "a place does not cease being a workplace simply because there is no work being carried out at a particular time." 736

The use of the HSWA definitions is intended to promote a consistent jurisprudence between the HSWA and the proposed new Act. New Zealand case law on the definition of "workplace" in the HSWA is yet to emerge, but should hopefully follow the Australian case law. Prior New Zealand case law offers little assistance, as consideration of the term was in relation to the Smoke-free Environments Act 1990, which contains a different and much more temporally connected definition of "workplace."

\footnotetext{
${ }^{734}$ HSWA, s 20.

${ }^{735}$ Safe Work Australia Explanatory Memorandum- Model Work Health and Safety Bill published on the Safe Work Australia website <https://www.safeworkaustralia.gov.au/doc/model-work-health-and-safetyact-explanatory-memorandum > at [48]. See also Telstra Corporation Ltd v Smith [2009] FCAFC 103, which impacts on this definition.

${ }^{736}$ Above, at [48]-[50].
} 


\section{b. "Working environment"}

The term "working environment" is used often in health and safety, business and human resources literature, referring to the space in which one works and its various physical, psychological and social characteristics. "Environment" is defined as "the circumstances, objects, or conditions by which one is surrounded" and includes the "aggregate of social and cultural conditions that influence the life of an individual or community." ${ }^{.737}$ Similarly, the Oxford Dictionary defines it as "the surroundings or conditions in which a person, animal, or plant lives or operates" and "the setting or conditions in which a particular activity is carried on." 738 This suggests "working environment" refers to the setting or conditions where work occurs, including the objects, or social and cultural conditions with which one interacts or is surrounded.

The term is not defined in legislation or case law, but has been discussed in Employment Court decisions such as Campbell v Commissioner of Salford School ${ }^{739}$ where it was associated with poor culture, intimidation, bullying, lack of trust, lack of professionalism in relationships, confrontational management style and poor communication. "Working environment" is intended to be wide enough to cover the traditional physical environment, including surfaces, substances, noise, vibration and air quality, and also aspects of workplace culture, including communication and relationships.

\section{c. "Work" not defined}

While the drafting refers to "work" and defines the associated terms "worker", "workplace" and "working environment", the proposed drafting does not provide a definition of "work." "Work" is not defined in the HSWA, the Australian equivalents, anywhere else in New

\footnotetext{
737 "Environment" in Merriam Webster Dictionary (7 Feb 2019) <https://www.merriamwebster.com/dictionary/environment>

738 "Environment" in Oxford English Dictionary (7 Feb 2019)

$<$ https://en.oxforddictionaries.com/definition/environment>

739 [2015] NZEmpC 122. 
Zealand law, nor the international labour standards instruments, and for good reason. "Work" is culturally and socially defined and the tasks or engagements considered to constitute "work" change over time and according to different contexts. For example, childcare performed while employed as a nanny or early childhood teacher is unquestionably "work". However, childcare performed by a parent may or may not be, depending on social context. Likewise, lawn mowing performed by a groundskeeper is unquestionably "work" but a person mowing their own lawns on the weekend would not typically be considered so.

While difficult to define in absolute or academic terms, the word has surprising clarity of meaning in its everyday use. ${ }^{740}$ Few individuals or their medical practitioners are likely to have any difficulty in determining what they do for "work", indeed "what do you do for work?" is usually one of the first questions a person is asked in social settings, typically without any ambiguity in the meaning of the question. This thesis proposes that whether something amounts to "work" is better dealt with by reference to the definition of "worker" in the HSWA, on a case-by-case basis, allowing for development to reflect changing social contexts. Helpfully, the definition of "worker" in section 19 of the HSWA includes volunteers. A "volunteer worker" is defined as an individual that "carries out work in any capacity for a PCBU" where the PCBU knows and consents, the volunteer works on "an ongoing and regular basis" and is "an integral part of the business or undertaking." 741

The definition excludes people "participating in a fund-raising activity", "assisting with sports or recreation for an educational institute, sports club, or recreation club", "assisting with activities for an educational institute outside the premises of the educational institution" or "providing care for another person in the volunteer's home." This definition of "volunteer worker" has two useful dimensions to it, the requirement that work be performed "for a PCBU", and that the tasks be performed on a voluntary basis, which should aid in shaping the law in any cases that arise. Firstly, the requirement that the "work" be "carried out for a PCBU" is likely to operate to exclude activities performed for oneself,

\footnotetext{
${ }^{740}$ Discussed in "Chapter One" of Paul Ransome The Work Paradigm (Ashgate, Hunts, 1996).

${ }^{741}$ HSWA, s19(3).
} 
such as cleaning one's own home or raising one's own children. It also likely excludes activities performed for people that do not fall within the definition of a PCBU, such as friends or family members. Secondly, the exclusions in section 19(3) only relate to those listed tasks (e.g. fundraising or assisting with sports) when performed "voluntarily". There is an existing body of case law in the employment jurisdiction on the meaning of "volunteer", ${ }^{742}$ and also a string of cases following the 2011 Court of Appeal decision in Idea Services Ltd v Dickson, which define "work" for the purpose of determining an employee's minimum entitlements. ${ }^{743}$ This existing case law, in combination with the explicit purpose section, and the indicative list included with the cover test, should help to guide the development of the law.

It is not anticipated that "work" will be defined to include unpaid domestic labour such as parenting or housework performed for oneself or one's family. While it is important for people performing such activities to be able to access compensation, and for such activities to receive greater social and economic recognition, they should not be included in the proposed new Work-Related Harm Part. The decision on the scope of the proposed WorkRelated Harm Part is determined by the aim to improve work health and safety. The prevention of injuries and illnesses acquired while performing unpaid domestic labour for oneself requires a very different response, as those tasks are performed in a different social, political, economic and legal context. Unpaid domestic labour does not involve the same relationship of unequal power relations as the relationship of employment and those akin to it (although of course different unequal power relationships may be present). The contractual relationship, the control of the work, and the control of the hazards of that work are different, as is the relationship of risk to the generation of "profits". Preventing injuries and illnesses in the performance of unpaid domestic labour requires a very different response and one that is developed specifically for that context. As discussed further in the next chapter, a significant piece of research into the cover of non-accident and non-work

\footnotetext{
${ }^{742}$ Kidd v Beaumont [2016] NZEmp 158.

743 [2011] NZCA 14; Cases following this decisions include Salad Bowl Ltd v Howe-Thonley [2013] NZEmpC 152; South Canterbury District Health Board v Sanderson [2017] NZEmpC 127; Ovation New Zealand Ltd v New Zealand Meat Workers Trades Union Inc [2018] NZEmpC 151; Labour Inspector (MBIE) v Smiths City Group [2018] NZEmpC 43.
} 
harm is currently being undertaken, and it is expected that unpaid domestic labour will fall within this category of proposed cover.

\section{A New Purpose Section for the Part}

As set out in the previous chapter, all provisions relating to work-related harm (whether accident or otherwise) would be dealt with in a new Part, with a single cover test. The new cover test is intended to operate with an explicit purpose statement. The proposed purpose section for the new Part would look as follows:

(2) The purpose of this Part is to:

(a) Recognise the rights of workers harmed through work;

(b) Provide for the comprehensive, fair and equitable compensation of workrelated harm;

(c) Ensure those who have suffered a work-related harm are able to return, to the fullest extent possible, to health, dignity and the ability to participate in economic, social, cultural and family life;

(d) Contribute to the improvement of health and safety in New Zealand workplaces, including through the collection of comprehensive statistics on work-related harm.

\section{A Recognising the rights of workers harmed through work}

As discussed in the previous chapter, the "rights" of workers could include the explicit legal rights in domestic law, under the HSWA, or international law, including the various ILO Conventions discussed above or Art. 23 of the UDHR. Given the explicit adoption of definitions from the HSWA, and subparagraph (d) beneath, there is a clear link between the health and safety and compensation legislation. The drafting does not define or limit the "rights" to those in the HSWA, allowing decision-makers the scope to consider wider legal or moral rights arising out of the relationship between the worker and the person 
engaging them to perform work. This drafting is intended as an indication that decisionmakers consider New Zealand's legal obligations under international instruments as well the jurisprudence on workers' rights and the "human rights" of workers.

\section{B Comprehensive, fair and equitable cover}

One of the stated purposes of the provision is to ensure comprehensive fair and equitable cover. "Comprehensive" is defined as "complete and including everything that is necessary" "44 or "including or dealing with all, or nearly all, elements or aspects of something." "745 The use of comprehensive in the proposed purpose section is intended to signal to decision makers that cover should be available to a wide range of work-related harms and that the test for cover should be interpreted to give effect to the aim of comprehensive cover. "Fairness" does not have a precise legal definition but has a considerable history of judicial and jurisprudential discussion. The concept of fairness is associated with ideas of even-handedness and impartial and just treatment, without favouritism or discrimination. Questions of fairness depend on the circumstances of the case, are procedural as well as substantive, and should grant discretion to the decisionmakers as to the fairest responses to questions of cover. As discussed in earlier chapters the codified diagnoses in the current ACA results in many workers being excluded for reasons with little basis in principle. The drafting is intended as an indication that the overall fairness of a decision ought to be considered when determining cover.

The word "equitable" has been included with fair. The word "equitable" obviously has a considerable history of judicial consideration and application. "Equitable" in an employment relations context, tends to mean particular recognition for groups of workers more likely to be excluded from benefits. "Equitable cover" should not exclude workers with health conditions associated with the hazards of newer or female-dominated industries, nor should it mean that an unfortunate past mandated an unfortunate future.

\footnotetext{
${ }_{744}$ Cambridge Dictionary Online (2 Jan 2019) $<$ https://ictionary.cambridge.org/dictionary/english/comprehensive $>$

${ }^{745}$ Oxford Dictionary Online (2 Jan 2019) <https://en.oxforddictionaries.com/definition/comprehensive> 
"Fair and equitable" cover also suggests decision-makers consider a wider set of cultural narratives of disease as evidence, including Māori models (discussed further below). "Fair and equitable" conveys a direction to decision-makers that there should be cover available, without discrimination, or arbitrary limitations, to any workers with harm sufficiently connected to work.

The language of "comprehensive, fair and equitable" also signals to decision-makers that such considerations are to be primary to considerations of efficiency, cost-saving or administrative simplicity. As echoed by Sir Geoffrey Palmer and others since the 1970s the lack of a principled basis for cover has allowed ACC to put its administrative considerations above injury prevention and the provision of social support. ${ }^{746}$ "Comprehensive, fair and equitable" also offers an explicit basis for subsequent judicial review of decisions.

\section{Health, dignity and participation}

This statement is intended to encourage the compensation agency and any decision-makers to consider workers as whole human beings, whose health, dignity, economic, social and cultural needs ought to be advanced through the provision of compensation and other support. This section reflects the labour law literature, especially the work of scholars following Sinzheimer, or adopting a human rights focussed analysis as discussed above in Chapter Three. ${ }^{747}$ For example, Art. 23 (3) of the UDHR provides that:

Everyone who works has the right to just and favourable remuneration ensuring for himself and his family an existence worthy of human dignity, and supplemented, if necessary, by other means of social protection

Gilabert argues that human dignity is a central concept in labour law and reflected in Art. 23. ${ }^{748}$ Adequate compensation for health conditions caused by work can be argued to aid

\footnotetext{
${ }_{746}$ Palmer, above at $\mathrm{n} 107$.

${ }^{747}$ See Sinzheimer, above at n 194.

${ }^{748}$ Pablo Gilabert "Dignity at Work” in Collins, Lester and Mantouvalou above at n 159, at 68.
} 
in achieving human dignity, ensuring those harmed are able to access medical care, rehabilitation and social support, as well as a sufficient income to prevent economic hardship for the worker and those dependent on them. Concepts like "health" and "dignity", much like "fair" and "equitable" lack precise meaning but convey a set of values and concepts likely to be understood by decision-makers. "Participation in economic, social, cultural and family life" is a phrasing that allows room for interpretation to respond to shifting social, cultural and economic climes. There is a considerable health and disability and wider social science literature on what "participation" means in different contexts, with recent discussion also provided by the United Nations in relation to the 2030 Agenda for Sustainable Development and the Convention on the Rights of Persons with Disabilities. ${ }^{749}$

The new Act is intended to ensure the provision of practical support to workers. First, through the provision of funding for medical treatment and rehabilitation. Poor physical or mental health is a barrier to participation in and of itself. The provision of adequate income compensation (presently $80 \%$ of pre-incapacity earnings) is also important, allowing the worker and their family to enjoy a similar standard of living to that enjoyed before the injury or illness. ACC currently also provides a range of other services including counselling, return-to-work planning, car, workplace or home modifications to aid mobility and independence, as well as retraining and practical support in obtaining alternative employment, where a return to work in the previous job is not possible. The word "cultural" is included to encourage the compensation agency to consider cultural factors when deciding on the appropriate support and to allow for a greater recognition of what constitutes valuable participation in a person's life.

\section{Improvement of health and safety in New Zealand workplaces}

The proposed purpose section for the Work-Related Harm Part explicitly states that it should "contribute to the improvement of health and safety in New Zealand workplaces". This contribution will occur primarily through the collection of data on work-related harm,

${ }^{749}$ See United Nations Department of Economic and Social Affairs Disability and Development Report 2018 (United Nations, New York, 2019). 
but is not limited to such, with specific obligations around information sharing and collaboration with WorkSafe imposed on the new Work-Related Harm Review Panel. As discussed in Chapter Four, ACC data forms the evidence base for health and safety policy and intervention. Data on a wider range of work-related health problems, and categorised by hazard, would provide a rich source of information to WorkSafe, employers, unions and researchers. While the specific codings and operation of the data collection system fall outside this thesis, there are examples of hazard-based workers compensation systems in operation, like the Australian Type of Occurrence Classification System (TOOCS) which could provide guidance. Given the common health and safety regulation between the countries, it makes sense to adopt something similar to that used in Australia, as this would allow for easier comparison and evaluation of New Zealand health and safety performance. It would also allow for greater research in to the effectiveness of interventions.

There may also be some impact, "incentivising" improved health and safety through levy avoidance, or allocation of BIC codes, ${ }^{750}$ but this is not the primary intention of this drafting. Chronic health problems with long lead-in times typically fail to provide economic incentives, as discussed in Chapter Three, and there are criticisms of the current Experience Rating System's ability to operate as an incentive, which also falls outside the scope of this thesis. ${ }^{751}$

The provision of compensation, treatment and return-to-work activities may also contribute to health and safety, by ensuring workers are able to access treatment and support. For example, workers able to access treatment and paid leave earlier in the progression of their mental health problems are potentially less likely to be in the workplace while unwell and more likely to return in a healthier state. While there is no data on this, intuitively, workers suffering from work-related mental health problems with no available paid leave, and potentially less access to treatment or support, are unlikely to be performing optimally or

\footnotetext{
${ }^{750}$ Business Industry Classification Codes. Information on the codes can be accessed on the Business Industry Classification Code website $<$ https://businessdescription.co.nz/\#/home $>$

${ }^{751}$ Nadia Dabee "A new paradigm for health and safety: Is it time to abandon experience-rating once and for all?” (2017) 42(1) NZJER 72.
} 
safely while at work, potentially negatively impacting on themselves and others in the workplace.

\section{$V$ A New Test for Cover}

The model proposed includes a new test for cover. Under the proposed section a person has cover if they have suffered a "work-related harm". This drafting is intended to sit immediately following the statement of purpose. Each of the paragraphs (a)-(i) of subsection (3) is explained in greater detail below, the inclusion of the subsections intended to give an explicit indication of the breadth and variety in the causal relationship between work and harm, but not to confine it to these.

(1) A person has cover if they have suffered a work-related harm.

(2) A work-related harm is a harm that has been caused by, triggered, exacerbated, or significantly contributed to, by the person's work.

\section{A Caused by, triggered, exacerbated, or significantly contributed to}

This language reflects the terminology often used in the Australian workers' compensation legislation. ${ }^{752}$ "Caused," as sets out in the previous chapter, is a word with a range of possible meanings and interpretations. The word "caused" is the least discussed in the worker's compensation case law also, as it is normally further defined in the statute or followed by other terms which denote a potentially lesser degree of causal connection than the word "cause" itself. The word "caused" has been retained to suggest to decisionmakers that an expansive interpretation of the other terms should be applied.

\footnotetext{
$\overline{752}$ Note: Workers' compensation is regulated at State level in Australia and there are a number of workers' compensation Acts which have been reviewed in the development of the drafting. No one specific test has been adopted for the proposal.
} 


\section{a. "triggered"}

A "trigger" is defined as "an event or situation... that causes something to start" "753 or "cause (an event or situation) to happen or exist", 754 or "to initiate or precipitate (a chain of events, scientific reaction, psychological process, etc."755 "Trigger" suggests that work or exposure to a particular work-related hazard might have "set-off" a health condition otherwise dormant or inactive, even if it is not the sole explanation for the development of the condition, or even a primary causal factor involved in that condition. Meanings of "trigger" could include environmental triggers of underlying genetic susceptibilities, or prior injuries, such as a previous back or knee injury that was otherwise stable, or an immune condition made manifest through the contracting of a virus or a period of stressful exhaustion. It could also be used to describe a bout of depression or other mental illness following a period of stressful work, or a situation of bullying or harassment, where the worker may have some prior history of mental illness.

\section{b. "exacerbated"}

"Exacerbated" means to "to make more violent, bitter, or severe" "756 or "to make something that is already bad worse." 757 Medical uses of the term mean "a worsening," and may "refer to an increase in the severity of a disease or its signs and symptoms." ${ }^{\circ 58}$ For a health condition to be "exacerbated" by a person's work, it implies they already had the condition and, as a result of some work-related hazard, the condition was made significantly worse.

\footnotetext{
753 "Trigger" in Cambridge Dictionary (8 Feb 2019) $<$ https://dictionary.cambridge.org/dictionary/english/trigger $>$

754 "Trigger" in Oxford Dictionary (8 Feb 2019) <https://en.oxforddictionaries.com/definition/trigger $>$

755 "Trigger" in Dictionary.com (8 Feb 2019) <https://www.dictionary.com/browse/trigger $>$

756 "Exacerbate" in Merriam Webster Dictionary (8 Feb 2019) <https://www.merriamwebster.com/dictionary/exacerbate>

757 "Exacerbate" in Cambridge Dictionary (8 Feb 2019) $<$ https://dictionary.cambridge.org/dictionary/english/exacerbate>

${ }^{758}$ Medical definition of "exacerbation" in the MedicineNet Dictionary (8 Feb 2019) https://www.medicinenet.com/script/main/art.asp?articlekey=24661> Identically defined in other medical dictionaries.
} 
This could involve conditions like asthma made worse by poor air quality at work, or back pain made worse by prolonged sitting or manual handling tasks. It could also refer to agerelated deterioration hastened or aggravated by an injury or illness. As in the example of Workers C, D and E in the previous chapter "exacerbated" is potentially a more helpful term in describing the causal relationship in cases of cardiovascular disease, or chronic diseases such as depression or back pain.

\section{c. "significantly contributed to"}

To "contribute" to something is to "play a part in bringing something in to effect" or to "help to cause, or bring about." "759 For work to "contribute to" the development of a harm, the hazards associated with a person's work would need to play a part in causing it, helping to bring the health condition in to effect. The extent of the contribution would need to be "significant", although this term or the extent of the significance are not defined. "Significantly" is a term that will require some interpretation by decision-makers, should the proposal be adopted. "Significant" has a variation in common meaning between UK and US English. UK uses of the word mean "important or noticeable" and US uses mean "important, large, or great, esp. in leading to a different result or to an important change."760 "Significant" denotes a larger contribution in US English than in UK English. The New Zealand Collins Dictionary contains a meaning closer to the UK use: "a significant amount or effect is large enough to be important or affect a situation to a noticeable degree" 761 although both meanings are likely used in New Zealand.

"Significant" also has technical uses in medical and epidemiological research which may colour the meaning when applied to chronic health problems. For a relationship to be

\footnotetext{
759 "Contribute" in Meriam Webster (12 Dec 2019)< https://www.merriamwebster.com/dictionary/contribute>

${ }^{760}$ See UK and US uses in Cambridge Dictionary (8 Feb 2019) $<$ https://dictionary.cambridge.org/dictionary/english/significant $>$

${ }^{761}$ New Zealand Collins Dictionary (8 Feb 2019)

$<$ https://www.collinsdictionary.com/dictionary/english/significant $>$
} 
"statistically significant" it is a relationship which is "not due to chance" although there is debate and disciplinary differences in how much of an effect ought to be treated as statistically significant. In borderline cases it is likely that epidemiological research disclosing PMRs and statistical relationships may be presented. A level of "statistical significance" is selected by researchers (most commonly $\alpha=0.05$ or 0.01 ). Notions of "medical significance" or "clinical significance" may also come in to play. In medicine and psychology, "clinical significance" is "the practical importance of a treatment effectwhether it has a real genuine, palpable, noticeable effect on daily life." 762

"Significant" also has legislated meaning and judicial discussion in overseas workers' compensation jurisdictions. Section 5B(3) of the Safety, Rehabilitation and Compensation Act 1988 (Cth) defines "significant degree" as "a degree that is substantially more than material." Courts in Australia have largely taken a practical approach, considering each case on its merits rather than creating hard and fast rules for what a "substantially more that material" contribution looks like. For example, in $S u v$ Comcare $^{763}$ the meaning of "contribution to a significant degree" was expressed as follows:

If the contribution is to a significant degree, it is beside the point that one factor contributes to a greater extent than another. Nor does it matter that factors outside the frame of employment also contribute to a significant degree. The Act does not require employment to be the sole, proximate or dominant cause of an injury.

In the leading High Court of Australia case, Gleeson CJ and Kirby $\mathrm{J}$ in Kennedy Cleaning Services Pty Ltd v Petkoska, stated: ${ }^{764}$

...there is a degree of ordinary meaning or common understanding involved... Medical evidence or opinion will, of course, be relevant; but it may not be determinative. The place of common-sense lay inference from a clear sequence of events is to be recognised, as long as any such inference is not denied by medical science. In any particular case there may be a consideration of whether there is a harmful effect on the body, a disturbance of the normal physiological state producing physical incapacity, a sudden or identifiable or distinct physiological change, whether there is an event or incident or clinical diagnosis to explain such change...The circumstances and the facts will

\footnotetext{
762 See A E Kazdin “The meanings and measurement of clinical significance” (1999) 67(3) Journal of consulting and clinical psychiatry 332.

763 [2011] AATA 934 (23 December 2011).

764 [2000] HCA 45; 200 CLR 286.
} 
influence what weight such considerations are given in the drawing of a factual conclusion in any particular case.

The test for "work-related harm" has been drafted to allow for flexibility. The drafting of the purpose section and the non-exhaustive list below is also intended to aid decisionmakers in determining borderline cases.

\section{B Allows greater scope for differing cultural meanings of disease}

The use of the broader framing should not only allow for newer medical thinking to be incorporated, but potentially, also other forms of knowledge. As discussed in the previous chapter, "diseases" are to an extent culturally defined, with Māori characterisations seldom recognised in the ACC case law. ACC is presently examining ways for its service to be delivered in a more culturally appropriate and responsive manner to Māori. ${ }^{765}$ Broader contextual and hazard-based conceptions of the causal relationships between work and health go some way towards allowing other forms of knowledge and thinking on health to be considered as evidence when determining claims. Allowing for the creation of less medicalised, and individualised narratives, and returning the focus to the interconnected relationships of work potentially also allows for the scheme to better respond to a wider set of cultural relationships between work and health to be considered.

\section{Non-exhaustive list}

To aid in the interpretation of "work-related harm", the drafting provides a non-exhaustive list of hazards, the exposure to which, may result in "work-related harm". As discussed in the previous chapter, this hazard-based drafting is intended to encourage a shift in thinking towards the link between health and safety and compensation and also anchor the formation of causal narratives to work.

\footnotetext{
${ }^{765}$ See Mauri Ora Associates, above at n 356.
} 
(3) For the purpose of subsection (2) work-related harm includes, but is not limited to, harm that arises:

(a) from exposure to hazards in, or of, the physical environment, including buildings, structures, vehicles, plant, machinery, tools, objects, materials, or surfaces;

(b) from exposure to temperature, radiation, noise or vibration in the working environment;

(c) from exposure to hazardous substances in the working environment;

(d) from exposure to infectious or pathogenic agents in the working environment;

(e) through the presence of, or interaction with, animals, birds, fish, reptiles, insects or other creatures, dead or alive, and including parts of, or products made from, in the working environment;

(f) through the presence of, or interaction with, people in the working environment (be they permitted in the working environment or otherwise), including bullying, harassment or violence;

(g) through the performance of work or specific work tasks;

(h) as a result of the organisation or arrangement of work, including times, hours, patterns or schedules, volumes or intensity of work (whether unreasonable or not);

(i) as a result of practices or processes used in the control or management of work (whether unreasonable or not), including the management of people and performance of work, or the manner or process of engagement to perform work, or dismissal from work.

a. "from exposure to hazards in, or of, the physical environment, including buildings, structures, vehicles, plant, machinery, tools, objects, materials, or surfaces"

The majority of work-related accidental physical injuries currently covered by ACC will fall within this category, but the focus of this drafting is on "the hazards in, or of, the 
workplace", not the specifics of the "accident". "Physical working environment" is a much wider concept that the "application of external force" under the current section 25 . This category would cover a wide range tool and machinery injuries, vehicles of any description, falls from height, either from buildings or from structures, slips or trips on surfaces, crushing or cuts. There is likely to be some overlap with harms in other categories. This overlap is not a problem given the list is intended to be indicative and decision-makers are encouraged to be "comprehensive, fair and equitable" in their interpretations.

\section{b. "from exposure to temperature, radiation, noise or vibration in the working environment"}

This set of hazards is commonly grouped together in the health and safety and occupational hygiene literature. Temperature can refer to either high temperatures resulting in burns and conditions like heat exhaustion, or low temperatures, including frost bite injuries or hypothermia. While most harms falling within "exposure to temperature" will be acute in nature, resulting from a short period of exposure to severe heat or cold (for the obvious reason that prolonged exposures to extremes of temperature are usually fatal), it could also cover chronic health problems such as skin or nerve conditions. This is a departure from s25(1)(e) which provides cover only where "any exposure to the elements, or to extremes of temperature or environment" occur "within a defined period of time not exceeding 1 month" and "that for a continuous period exceeding 1 month, results in any restriction or lack of ability that prevents the person from performing an activity in the manner or within the range considered normal for the person."

Vibration has long been linked to a number of medical conditions, including damage to the circulatory system of the upper extremities (Raynaud's syndrome), to the peripheral nerves (peripheral neuropathy), and to the bones and joints (aseptic necrosis, fatigue fractures, degenerative joint disease). ${ }^{766}$ Vehicles and machines causing floor vibration can cause

\footnotetext{
${ }^{766}$ See WHO "Occupational exposures to vibration for hand held tools (Protecting Workers Series 10)" $<$ https://www.who.int/occupational_health/pwh_guidance_no.10_teaching_materials.pdf $>$
} 
degenerative disc disease of the lumbar spine. "Radiation" is a broad term for the "the emission of energy as electromagnetic waves or as moving subatomic particles, especially high-energy particles which cause ionization."767 The term "radiation" is not confined to natural, chemical or man-made sources and can include both acute and chronic health effects such as radiation sickness, cancers, severe sun burns or melanomas. The drafting of this provision is intended to cover a wide range of employees working in fields such as medical imagining, agrichemicals, and those working outdoors and exposed to the sun. There is a considerable body of evidence on skin cancer and solar ultra violet radiation exposure. New Zealand has one of the highest rates of melanoma in the world so it is likely that there will be claims made for this. ${ }^{768}$

Hearing loss related to exposure to work-related noise is well established and has been compensated in New Zealand for a long time. There is also evidence linking noise exposure to elevated rates of cardiovascular disease, and other mental and physical illnesses. ${ }^{769}$ The current ACA confines cover to a "degree of hearing loss that is $6 \%$ or more of binaural hearing loss caused by a personal injury" in circumstances set out in s 20(2). The proposed drafting above would expand cover to any "harm" sufficiently causally connected to exposure to work-related noise, including other types of health conditions.

\section{c. "from exposure to hazardous substances within the working environment"}

"Hazardous substances" has both a general and technical meaning, which are helpfully similar to each other. The word "hazard" in common use means something which involves “exposing one to risk of loss or harm." 770 A "substance” simply means "physical material

\footnotetext{
${ }_{767}$ Oxford English Dictionary (8 Feb 2019) < https://www.lexico.com/en/definition/radiation>

${ }^{768}$ Melanoma New Zealand website $<$ https://www.melanoma.org.nz/be-informed/understanding/>

${ }^{769}$ See Thomas Münzel, Tommaso Gori, Wolfgang Babisch and Mathias Basner "Cardiovascular effects of environmental noise exposure" (2014) 35(13) Eur Heart J 829; and Xiaoyuan Wu, Daya Yang, Wendong Fan, Chunyue Fan and Guifu Wu "Cardiovascular Risk Factors in Noise-Exposed Workers in China: Small Area Study” (2017) 19(91) Noise Health 245.

770 "Hazardous" in Meriam Webster Dictionary (3 Mar 2019) <https://www.merriamwebster.com/dictionary/hazardous>
} 
from which something is made or which has discrete existence" or "a particular type of matter with uniform properties." 771 The phrase implies some kind of material which may cause harm. This mirrors the technical use of the word "hazard" in health and safety law, defined in the previous HSEA as "an activity, arrangement, circumstance, event, occurrence, phenomenon, process, situation, or substance (whether arising or caused within or outside a place of work) that is an actual or potential cause or source of harm." ${ }^{\prime 772} \mathrm{New}$ Zealand has a Hazardous Substances and New Organisms Act 1996 (HSNOAct), which defines a "hazardous substance" as:

...unless expressly provided otherwise by regulations or an EPA notice, any substance-

(a) with 1 or more of the following intrinsic properties:

(i) explosiveness:

(ii) flammability:

(iii) a capacity to oxidise:

(iv) corrosiveness:

(v) toxicity (including chronic toxicity):

(vi) ecotoxicity, with or without bioaccumulation; or

(b) which on contact with air or water (other than air or water where the temperature or pressure has been artificially increased or decreased) generates a substance with any 1 or more of the properties specified in paragraph (a).

New Zealand's hazardous substances regime reflects the international classifications regime. Hazardous substances are divided in to nine classes, with UN Numbers, under the United Nations framework. ${ }^{773}$ The nine classes are incorporated in to New Zealand law, presently through the Hazardous Substances (Classification) Notice 2017 under the Health and Safety at Work (Hazardous Substances) Regulations 2017.

Classes 1-5 relate to substances which are explosive, flammable, or have the capacity to oxidise. Most of the harms resulting from exposure to these substances, being that

\footnotetext{
771 "Substance" in Meriam Webster Dictionary (3 Mar 2019) <https://www.merriamwebster.com/dictionary/substance>

772 "Hazard" HSEA, s 2.

${ }^{773}$ For information about the UN Hazardous Substances Framework see $<$ http://www.dgiglobal.com/classes $>$
} 
they explode or cause fires, are serious injuries or burns falling within s 25 of the ACA. Many of these harms will also fit within the proposed clause (a) which involves exposure to hazards in the physical environment. There are generally fewer causal issues associated with injuries resulting from fire or explosion. Of more importance for this thesis is Class 6, which provides for substances toxic to human health. Categories 6.1A-6.1E (see below), are usually covered under the current ACA, either because they cause acute poisoning, falling within s 25(1)(b), or are fatal.

The proposed drafting would potentially provide for a wider range of occupationally linked skin conditions, through exposure to irritants or sensitizing agents (categories 6.3, 6.5 and 8.2). There are a wide range of occupations affected by substance exposure-related skin conditions including those working in printing, painting, manufacturing, construction, health services, cleaning and hairdressing. This category would cover a wider range of occupationally linked respiratory conditions, including occupationally caused, exacerbated, or triggered asthmas. Respiratory conditions affect many workers in agriculture and animal care, printing and manufacturing, textiles, food production, welding, metal and woodwork. There is presently some cover for these conditions under the ACA section 30 or the Occupational Diseases Schedule but the proposed drafting would expand on this. 


\section{Diagram: Class 6 Toxic Substances Classification}

\begin{tabular}{|c|c|}
\hline $6.1 \mathrm{~A}$ & Substances that are acutely toxic - Fatal \\
\hline 6.1B & Substances that are acutely toxic - Fatal \\
\hline 6.1C & Substances that are acutely toxic- Toxic \\
\hline 6.1D & Substances that are acutely toxic - Harmful \\
\hline 6.1E & Substances that are acutely toxic-May be harmful, Aspiration hazard \\
\hline 6.3A & Substances that are irritating to the skin \\
\hline 6.3B & Substances that are mildly irritating to the skin \\
\hline 6.4A & Substances that are irritating to the eye \\
\hline $6.5 \mathrm{~A}$ & Substances that are respiratory sensitisers \\
\hline 6.5B & Substances that are contact sensitisers \\
\hline 6.6A & Substances that are known or presumed human mutagens \\
\hline 6.6B & Substances that are suspected human mutagens \\
\hline 6.7A & Substances that are known or presumed human carcinogens \\
\hline 6.7B & Substances that are suspected human carcinogens \\
\hline 6.8A & $\begin{array}{l}\text { Substances that are known or presumed human reproductive or } \\
\text { developmental toxicants }\end{array}$ \\
\hline 6.8B & $\begin{array}{l}\text { Substances that are suspected human reproductive or developmental } \\
\text { toxicants }\end{array}$ \\
\hline 6.8C & $\begin{array}{l}\text { Substances that produce toxic human reproductive or developmental } \\
\text { effects on or via lactation }\end{array}$ \\
\hline 6.9A & Substances that are toxic to human target organs or systems \\
\hline 6.9B & Substances that are harmful to human target organs or systems \\
\hline
\end{tabular}

The wider coverage of "hazardous substances" would also extend the cover available to specific organ toxicants beyond current provision. Specific organ toxicants are substances which cause damage to, or the development of a disease in, a specific organ, such as liver, lung or kidney diseases. Some of these are specifically provided for in the ILO Schedules, and specified in the Occupational Diseases Schedule, such as clause 21 "angiosarcoma of 
the liver diagnosed as caused by vinyl chloride monomer" or clause 33 "bladder carcinoma diagnosed as caused by 2-naphthylamine, benzidine, 4-aminobiphenyl, N, N-Bis (2chloroethyl)-2-naphthylamine, other aromatic amines, or poly-cyclic aromatic hydrocarbon". There are however a larger number of conditions presently excluded.

Perhaps the most significant area of coverage for future developments are categories 6.6, 6.7 and 6.8, mutagens, carcinogens and teratogens. ${ }^{774}$ There has been little coverage or wider case law in New Zealand to date, but there has been recent discussion and legal action overseas that indicates future activity in New Zealand is possible. Research in to the effects of exposures on the development of various cancers, the mutation of DNA and on reproductive health has moved rapidly in the previous decades. This area has the potential to move quickly as new research emerges. The proposed drafting is intended to provide a link to the wider hazardous substances research and classifications and a clear purposive statement with which to evaluate new claims.

The final category of "hazardous substances" which may result in claims are diseases caused by exposure to radioactive materials. Radioactive materials are class 7 in the international classification system but are excluded from the HSNOAct, as the regulation of these materials is contained in the new Radiation Safety Act 2016. While radioactive substances do not fall within the HSNO definition it is unlikely the courts would interpret the compensation of work-related harm to exclude these substances on that basis.

Using the term "hazardous substances" is intended to help in aligning the compensation of work-related harm with the local and international regulatory regime for its prevention. It also offers practical guidance for decision-makers and assistance with the evaluation of technical evidence. To receive a classification, hazardous substances are evaluated by

\footnotetext{
${ }^{774} \mathrm{~A}$ "mutagen" is a substance that causes genetic mutation, a "carcinogen" is a substance that causes cancer in living tissues, and a "teratogen" is a substance which causes malformation of an embryo.
} 
international experts and a report is produced and periodically updated. ${ }^{775}$ For example, carcinogenic, mutagenic and teratogenic substances are divided in to two levels, A and B, reflecting the current state of evidence. For example, mutagenic substances are divided in to 6.6A "known or suspected mutagens" and 6.6B "suspected mutagens." The evidence is provided with the classification documents and the substances themselves must be labelled with the classification. ${ }^{776}$ It may make it easier for claimants to establish causal connection where substances already have an evidential classification, and this is marked on the substances themselves. This may also encourage workers and employers/PCBUs to take greater note of the Safety Data Sheet classifications and suggested safety equipment and safe handling practices.

\section{d. "from exposure to infectious or pathogenic organisms or agents within the working environment"}

This category is intended to ensure cover is available to a wider range of infectious diseases contracted through exposure to animals and humans, carcasses, food, fungi, bacteria, infected materials or waste products. Unlike the current ACA it does not specify a given mode of exposure (e.g. via arthropod as vector in section 25(2)(c)), or a given disease (e.g. leptospirosis diagnosed as caused by working with animals or their carcasses in cl. 17 of the Schedule). The ordinary definition of "pathogenic" means "causing or capable of causing disease."777 "Organism"- includes bacteria, fungi and viruses and an "agent" is "a person or thing that takes an active role or produces a specified effect." $" 778$

\footnotetext{
775 For more information on this process see the United Nations Economic Commission for Europe website at $<$ http://www.unece.org/trans/danger/danger.html $>$

${ }^{776}$ For more information on evidence requirements for thresholds see Environmental Protection Authority (NZ) Thresholds and Classifications under the Hazardous Substances and New Organisms Act 1996 (January 2012).

777 "Pathogenic" in Merriam Webster Dictionary (6 May 2019) <https://www.merriamwebster.com/dictionary/pathogenic>

778 “Agent" in Merriam Webster Dictionary (6 May 2019) <https://www.merriamwebster.com/dictionary/agent>
} 
This drafting does not limit cover to those conditions with the status of "occupational disease" covering a wider range of infections sufficiently causally connected to work. This wider category could include infections contracted by health care workers working with patients, teachers working with students, or corrections officers working with inmates as well as rubbish collectors and recyclers handling infectious materials, environmental and water treatment officers, and those working in sewerage treatment facilities or medical laboratories. While it could potentially expand to infectious diseases circulating around the office, there would likely be evidential difficulties in establishing the particular person or agent, operating as a limit to such claims. Such claims would also likely be limited by the requirements of making the claim and the requirement the employer pay the first weeks' leave.

e. "through the presence of, or interaction with, animals, birds, fish, reptiles, insects or other creatures, dead or alive, and including parts of, or products made from, in the working environment"

This category is intended to cover "zoonotic conditions" and any health conditions relating to "animals, birds, fish, reptiles or other creatures". Most of these conditions will either be physical injuries such as being bitten, kicked, crushed or stung, or exposure to infectious agents associated with handling animals or carcasses, and may have some overlap with (d). The category could also include other conditions, such as respiratory conditions associated with the inhalation of animal fibres or dander, skin conditions associated with handling carcasses or hides, or even mental health conditions associated with exposure to slaughterhouse killing floors.

f. "through the presence of, or interaction with, people in the working environment (be they permitted in the working environment or otherwise), including bullying, harassment or violence"

This category is intended to ensure cover is provided to a broad range of hazards associated with people, including situations of bullying, general, sexual or racial harassment or 
violence by someone in the workplace. It could include a range of management, communication or interpersonal conflicts, where these result in some harm within the definition, as well as conduct such as stalking, cyber bullying, or sexual or physical assault. This drafting is intended to suggest that the person or people could be a manager, fellow worker, client, patron, patient, inmate, student or visitor to the workplace, or someone not permitted to be in the workplace such as an armed robber of a petrol station or liquor store. The proposed drafting of "harm" would mean the provision of cover for both the mental and physical health consequences of being bullied, assaulted, stalked or harassed.

This category is drafted to cover "a person" or "people" suggesting one-off traumatic events as well as health problems resulting from repeated exposures or problems with multiple people in a workplace. It does not define or limit cover to "bullying" or require proof that the person's conduct does objectively amount to bullying as against a legal standard. It is enough that there is a harm suffered by the worker meeting the definition, and that harm is sufficiently connected to the actions of a person or people in the working environment meeting the definition of "work-related harm". Providing cover in these situations would likely resolve many of the inspection and enforcement request problems for WorkSafe and eliminate a large number of personal grievances associated with the poorly defined, and often difficult to determine, allegations of bullying. As it would also potentially include situations of poor management and workplace conflict that fall short of a breach of the HSWA and it may also remove the incentive to pursue many other unjustifiable disadvantage personal grievances (at least in relation to compensation for the harm suffered).

\section{g. "through the performance of work tasks"}

This category is intended to ensure cover is available to health conditions associated with the performance of hazardous tasks while working. It would cover the performance of physical tasks, such as typing, repetitive work, manual-handling, lifting, stretching, prolonged sitting, or use of a particular tool. Many of these health conditions would fall within the current s 25 (e.g. lifting), or within s 30, involving a gradual process. The 
proposed drafting would likely cover a much wider range of health conditions, arising from a much wider variety of tasks, covering mental and emotional tasks presently excluded from s 30, including the tasks associated with caring, counselling, teaching or serving others. This category may overlap with the other categories listed. Some overlap is unavoidable and consistent with the "indicative" nature of the categories listed and a comprehensive and purposive approach.

\section{h. "exposure to hazards associated with the organisation or arrangement of work, including hours of work, patterns or schedules, volumes or intensity of work"}

This category is intended to ensure cover is provided to health conditions resulting from the way work is organised or arranged. For example, this category would cover health problems linked to shift-work. Shift-work is associated with an increased risk of developing cardiovascular, metabolic, gastrointestinal disorders, some types of cancer, and mental disorders, including depression and anxiety. ${ }^{779}$ In women, shift-workers have a higher incidence of obesity, high blood pressure, ${ }^{780}$ and breast cancer. ${ }^{781}$ Shift-work has also been connected with a range of reproductive problems, including endometriosis, miscarriage, low birth-weight and pre-term delivery. ${ }^{782}$ There is even a condition called "shift-work sleep disorder" which is recognised by the medical profession. ${ }^{783}$ Shift-work

\footnotetext{
${ }^{779}$ DB Boivin, GM Tremblay and FO James "Working on atypical schedules" (20707) 8(6) Sleep Med (2007) 578; R Foster and K Wulff “The rhythm of rest and excess" (2005) 6(5) Nat Rev Neurosci 407; and F Scheer, M Hilton, C Mantzoros and S Shea "Adverse metabolic and cardiovascular consequences of circadian misalignment” (2009) 106(11) Proc Natl Acad Sci U S A 4453.

${ }^{780}$ JD Chen, YC Lin and ST Hsiao "Obesity and high blood pressure of 12-hour night shift female clean-room workers" (2010) 27(2) Chronobiol Int 334.

${ }^{781}$ E Schernhammer, F Laden, F Speizer, W Willett, D Hunter and I Kawachi "Rotating night shifts and risk of breast cancer in women participating in the nurses' health study" (2001) 93(20) J Natl Cancer Inst 1563.

${ }^{782}$ Karen L Gamble, David Resuehr and Carl Hirschie "Shift work and circadian dysregulation of reproduction" (2013) 4(92) Front Endocrinol 1.

${ }^{783}$ Information on shift-work sleep disorder can be found at National Sleep Foundation (US) "Shift-Work Sleep Disorder Symptoms" < https://www.sleepfoundation.org/shift-work-disorder/what-shift-workdisorder/shift-work-disorder-symptoms>
} 
is a feature of many occupations, including health care, manufacturing, electricity and infrastructure provision, security and policing, hospitality and food production and distribution.

This category would also cover many stress-related conditions associated with high volumes of work, long hours, or "intensified" work. It would cover health conditions associated with what is called "burn-out" or "care fatigue" including depression, ergonomic wrist or back pain and other diagnoses. This category has been drafted to ensure that cover is available where health problems can be attributed to excessive workloads, long hours, or the mental or emotional load of the work. It is wide enough to capture changes in the way workers are working, including platform and gig work. It is also potentially wide enough to capture the stresses associated with the precarity, vulnerability or unpredictability of certain working arrangements. There is no requirement to show that the arrangements are unreasonable, or amount to a breach of the HSWA (although this is likely to be the case) and workers affected need only raise the presumption that their harm was "caused by, triggered, exacerbated, or substantially contributed to" by their work.

i. "as a result of practices or processes used in the control or management of work (whether unreasonable or not), including the management of people and performance of work, or the manner or process of engagement to perform work, or dismissal from work"

This category is likely to be the most controversial expansion in cover and allows for the cover of health problems associated with hazardous management practices, performance management processes, organisational restructuring or dismissal processes. This category will most likely result in claims for mental or stress-related health problems, but "processes used in the control or management of work" is not limited to such and is potentially able to extend to decisions which increase the physical or substance exposure hazards of work. This drafting would allow for compensation where a poorly handled disciplinary or dismissal process (including redundancy) resulted in some health problem able to meet the definition of harm. 
This extension of cover would bar the recovery of damages for the covered medical condition and incapacity-related earnings loss, but not prevent an employee challenging through the personal grievance system for other losses associated with unfair processes, unpaid contractual entitlements or for compensation unrelated to their medical condition. This extension of cover would likely have an impact on claims in the employment relations jurisdiction, potentially reducing the incentives of employees to pursue grievances in some situations. It is difficult to fully appraise the impact of this as there is little data from either the Employment Relations Mediation Service or the Authority on the proportion of claims brought where damages for mental or stress-related illness or recovery of health costs is sought. Likewise, there is no data on how many employees currently decide not to pursue a grievance due to poor mental health. This extension of cover would allow employees affected by medical conditions "caused, triggered, exacerbated or significantly contributed to" by their employer/manager's stressful management processes to obtain compensation.

The Australian workers' compensation jurisdictions often include an exclusion for "reasonable management actions." This approach is rejected as an assessment of "reasonableness" is an unsuitable task for compensation agency staff to have to make, and also introduces an element of fault in to the requirements for cover which should be avoided. While the proposed approach aims to reorient attention to "work" and encourage improved health and safety it should not introduce fault-based evaluations. Determining the "reasonableness" of the actions which give rise to the harm is a matter better left to WorkSafe or the employment relations jurisdiction. 


\section{Harm to third parties affected by exposure to a transmitting worker}

This provision allows for individuals who develop health problems through secondary exposure to claim compensation under the proposed Work-Related Harm Part.

(1) Cover is available where a person suffers a harm through a transmitting worker.

(2) Harm through a transmitting worker means a harm that has been acquired through contact with a worker, and includes harm:

(a) through contact with worker garments, tools or equipment capable of transmitting a source of harm; or

(b) transmitted by the worker through an infectious agent; or

(c) transmitted to offspring via in-utero exposure, infected breastmilk or inherited through affected genetic material.

The drafting of this section includes cases of family members that are exposed to hazardous substances on the worker, or on their clothes, equipment or in their vehicles. For example, there have been a number of cases where partners have contracted mesothelioma or asbestos related diseases by inhaling asbestos containing dusts while washing or handling contaminated clothes. Contaminated dusts on clothing is a known vehicle for secondary transmission of respiratory diseases and some cancers.

This provision also covers situations where family or other close associates contract infectious diseases through contact with an infected worker or a worker that is a carrier of a disease related to their work. Although there have been no prominent New Zealand cases of this occurring, there are overseas cases where the children of farm or meat workers contract rare animal diseases, sometimes with severely disfiguring or fatal consequences. The Ministry of Primary Industries in New Zealand regards this as a significant health risk 
in the agricultural sector. ${ }^{784}$ Claims for infectious diseases are likely to be limited in practice, due to the lack of evidence of worker transmission where common infectious diseases are contracted, and by the severity of the illness (sick leave being applicable). It is anticipated this provision will likely be used by people related to workers in the health care sector and those related to people working with animals and carcases, although cases could involve people related to environmental officers, or those handle waste products.

Another significant group of people intended to be provided cover under this section are children who have suffered birth defects or inherited diseases from a parent exposed to a hazardous substance through work. This would cover situations of exposure to teratogenic substances (Category 6.8) prior to conception, or during pregnancy, or where individuals have suffered conditions caused by substances transmitted via breast milk (Category 6.8A). A number of substances are known to have potential reproductive effects, including heavy metals (lead, cadmium), organic solvents (glycol, ethers, toluene, vinyl chloride), pesticides and herbicides (ethylene dibromide), and sterilants and anaesthetic gases. There are, however, significant gaps in this area of research, which results in uncertainty in the available evidence and makes it difficult to estimate the number of potential claimants. ${ }^{785}$

While it has long been recognised hazardous substances may travel to a foetus through the mother, it was generally assumed there was very little effect on offspring where fathers had been exposed prior to conception. This assumption is now being challenged as reproductive science has advanced in recent decades. While there are difficulties with the data, estimates are that 3 per cent of major malformations are strictly attributable to a known toxicant exposure, about 28 per cent to genetic causes, and 23 per cent attributable to the complex interactions between genes and environmental factors. ${ }^{786}$ Occupations with exposure to

\footnotetext{
${ }^{784}$ Mueller, Kells and Campbell, above at n 302.

${ }^{785}$ Christina Lawson, Teresa Schnorr, George Daston, Barbara Grajewski, Michele Marcus, Melissa McDiarmid, Eisuke Murono, Sally Perreault, Steven Schrader, and Michael Shelby “An Occupational Reproductive Research Agenda for the Third Millennium" (2003) 111(4) Environmental Health Perspectives 584, at 584 .

${ }^{786}$ G Oakley "Frequency of human congenital malformations" (1986) 13(3) Clin Perinatol 545; Paul Himmelstein "Reproductive hazards in the workplace: what the practitioner needs to know about chemical
} 
potential reproductive toxicants include veterinary, dental, and medical and health care workers, lab technicians, agricultural workers, workers in construction, automobile mechanics and auto body shop workers, firefighters, chemical industry workers, iron workers, janitorial workers and cleaners, dry cleaning and laundry workers, metal fitters, electronic technicians, machinists and people in other metal trades. ${ }^{787}$

This proposed section would also potentially cover individuals who have inherited health conditions where parents were exposed to mutagenic substances (category 6.6A and 6.6B) and this mutation has been passed on to offspring resulting in disease. This area of research is still relatively new, and in its present state, is unlikely to support many cases. As the research and technology develops, however, there may be more provable cases of hazardous substance exposure related mutation transmission.

The drafting revolves around the term "transmitting." "Transmit" is defined as "to send or convey from one person or place to another," "to cause (something) to pass on from one person or place to another," "to cause or allow to spread" or to "convey by or as if by inheritance or heredity, to hand down." ${ }^{.788}$ The term is broad, allowing for a variety of mechanisms of transmission. The drafting explicitly anticipates transmission via dusts on person, equipment or clothing, infectious agents or transmission of genetic material but also allows for other "vehicles of transmission." This drafting hopefully allows for those known cases, and also for cases that may come to be recognised as a result of scientific advances. "Harm" has the same meaning as defined above, and includes death, injury, disease, medical condition (either physical or mental), or loss of, or impairment of, function.

This section was included with the proposed Work-Related Harm Part, as it is consistent with the goals and approach of this thesis. Providing cover to individuals where the worker

exposures" (1988) 71(6) Obstet Gynecol 921; LB Holmes "Impact of the detection and prevention of developmental abnormalities in human studies" (1997) 11 Reprod Toxicol 267.

${ }^{787}$ See Lawson and others, above at 785.

788 "Transmit" Merriam Webster (13/5/19) < https://www.merriam-webster.com/dictionary/transmit> "Transmit" in Oxford English Dictionary <https://en.oxforddictionaries.com/definition/transmit> 
has been an agent of direct transmission recognises an important source of work-related harm which results from poor health and safety. It allows for data to be collected and a clearer picture of the costs and consequences of hazard exposure to emerge. As mentioned above there is remarkably little attention given to this area (as with hazardous substance exposures generally) and cover would help to increase the public visibility of these issues. These secondary harms involve a direct causal connection with the worker as the transmitting agent, and as it is likely the majority of claimants will be family or closely related to the worker, could also be viewed as a form of harm suffered by the worker themselves (although not always). Harm to the transmitting worker would not need to be established for such claims to succeed. The inclusion of this provision is consistent with the approach in the HSWA, which includes a duty to "others" who may be affected by the work of the PCBU under s36.

\section{Other Associated Matters}

\section{A A new Review Panel on Work-Related Harm}

Review Panel on Work-Related Harm

(1) The functions of the work-related harm review panel is to:

(a) Review work-related harm claims which are complex or novel, and make a determination of cover that is consistent with the purposes of this Part;

(b) Provide written reasons for the decision to the claimant;

(c) Compile and make publicly available (in an anonymised form) determinations of work-related harm decisions;

(d) Consider work-related harm trends and provide appropriate guidance or recommendations to the Minister on relevant matters;

(e) Provide information and guidance to WorkSafe New Zealand and other agencies on work-related harm trends and other relevant matters. 
The proposal has been drafted with a range of current and potential actors in mind, including front-line, data collection and policy staff working for the compensation agency, researchers, policy and enforcement staff at WorkSafe, staff in other agencies, medical practitioners, unions and claimant advocates, as well as a specialist review panel and the courts. The majority of claims are not expected to be complex or difficult to determine. It is intended, as discussed in the previous chapter, that a worker's doctor or other healthcare provider would make a claim on their behalf as is currently the case. The claim would be made using new forms or an online application process that would need to be developed to reflect the new cover provisions and data collection goals (these forms have not been prepared as part of this thesis.)

More difficult or complex claims could involve further requests for information from the claimant or healthcare provider and/or advanced to the Review Panel on Work-Related Harm. This panel is intended to be an internal process for handling more complex claims, the decisions of which could then be appealed to the existing tribunal or courts. The administrative or appointment machinery for this panel is not discussed in this thesis, but it is anticipated the panel would be comprised of work-related harm specialists, with appropriate skills and experience in matters of occupational health, work health and safety and claims determination. The primary function of the panel would be to determine cover according to the aims of the Part (discussed above), keep records and make determinations publicly available (in an anonymised form of course) as well as advise the Minister, WorkSafe and others on work-related harm trends or other relevant matters. Panel decisions would be reviewable by the tribunal and the courts, with the written reasons for the decision provided to the claimant (and the anonymised determinations) provided to aid advocates in assessing whether to appeal the matter. The publicly available determination records also help to increase transparency and accountability, helping inform medical practitioners, unions and health and safety advocates on the types of claims accepted or rejected and the reasons for this.

The published determinations should also help to build a richer picture of the hazards and resulting health problems affecting New Zealand workplaces. The proposal in this thesis 
anticipates that data will primarily be collected from the original claims forms (and thus coded in to hazard-based category) allowing for raw numbers and costs, industry-based classifications and gender, age and ethnicity data to be collected. The determination records are also an important source of data allowing for more detailed information on the relationships between specific hazards and health problems to be captured. These are likely to be particularly valuable to work health and safety researchers, unions, employer-groups and WorkSafe.

It is important to note that a recent report has advocated for an independent ombudsman for ACC, and if such recommendations are accepted, this proposal for a review panel sitting within the agency would need to change. ${ }^{789}$

\section{B Costs implications}

As set out above, in Chapter Four, there is no reliable data on the conditions presently excluded from ACC cover, making any reliable prediction about cost implications of the proposal very difficult. It may be possible to develop some estimate based on current ACC claims and international trends in workers' compensation and insurance, but it is beyond the scope of this thesis to attempt this. It is reasonable to assume, however, that the proposed expansion in cover, if implemented, would likely increase the amounts paid in compensation and consequently the levies payable in a number of industries. In particular, it is likely that implementation of the proposal would see a sharp increase in costs associated with work-related mental health problems and stress-related illnesses, although this may be off-set by reduced costs in other areas of health and welfare provision, and to employers in sick leave use, and personal grievance compensation.

Looking to international experience, work-related mental health conditions often require a longer period of leave than claims on average, increasing the associated costs. Australian workers' compensation claims required an average of 15.3 weeks compared to 5.5 weeks

\footnotetext{
${ }^{789}$ Forster, Barraclough and Mijatov, above at $\mathrm{n} 9$.
} 
for all claims, although it is important to note there is a recognised under reporting, suggesting the mental health claims being made represent the most severe cases. ${ }^{790}$ Safe Work Australia figures put work-related mental health claims at $6 \%$ of workers' compensation claims, with approximately $\$ 543$ million paid in workers' compensation to 7,200 Australians. ${ }^{791}$ As discussed in Chapter Four, it is reasonable to assume the number of worker mental health claims would be at least as large, if not larger, than in the Australian workers' compensation regimes.

In 2018 the New Zealand Government set up the Government Inquiry in to Mental Health and Addiction recognising New Zealand's "mental health" crisis. While the inquiry spent disappointingly little time on the impacts of the workplace, the Report offers an indication of the wider costs associated with mental health problems. In He Ara Oranga: Report of the Government Inquiry in to Mental Health and Addiction, it was concluded that: ${ }^{792}$

The economic costs of mental illness are substantial. Recent estimates for OECD countries are that mental illness reduces gross domestic product (GDP) by approximately $5 \%$, through disability leading to unemployment, work absenteeism and reduced productivity, and the additional costs of physical health care among people with mental health problems.

The proposed expansion of cover to work-related mental health problems, although increasing the costs of compensation paid by the scheme, should ensure workers with workrelated mental health conditions are better able to access treatment, rehabilitation and support, as well as taking paid time off work to recover. The costs of work-related mental health problems are presently borne by employers, public and community healthcare providers, and individual workers and their families. As discussed in Chapter Four, workers that are unable to access ACC cover are either using sick leave, turning up to work unwell (with the associated costs and productivity impacts), leaving the workplace or labour market entirely, accessing the benefit system, or suing through the personal grievance regime.

\footnotetext{
790 Safe Work Australia data on work-related mental health claims (at February 2019) $<$ https://www.safeworkaustralia.gov.au/topic/mental-health\#snapshot-of-claims-for-mental-health $>$

${ }^{791}$ Safe Work Australia figures (at February 2019) <https://www.safeworkaustralia.gov.au/topic/mentalhealth\#snapshot-of-claims-for-mental-health>

${ }^{792}$ Government Inquiry in to Mental Health and Addiction, above at n 295, at 97.
} 
This thesis asserts that ACC (or the proposed compensation agency to replace it) is the most appropriate and efficient place for the costs of work-related health problems to be met, reducing the litigation risk and sick leave burden on individual employers, increasing access to treatment, rehabilitation and support, and ensuring a healthy workforce, as well as aiding in improving health and safety responses to the underlying problems. Operating well, an expanded provision of cover through the compensation agency may reduce costs in other areas, including the general health system and benefit system, as well as the costs associated with lost-productivity, sick leave use, absenteeism and presenteeism, personal grievance compensation and poor workplace culture.

\section{Possibility of a fully comprehensive social insurance scheme in future}

As discussed above, there are presently calls to radically expand the scheme to achieve the original Woodhouse vision of a comprehensive social insurance scheme for all the hazards of modern living. While the Minister has dismissed this type of reform for the foreseeable future, the option has been considered in the development of the proposed reforms. While the new Act proposed in the previous chapter, and the drafting above, was designed to operate within a scheme of similar scope to that operating presently, the proposal does not prevent, and may even facilitate the wider expansion of the scheme. Segmenting the scheme into Parts as proposed allows for further categories of harm to be added incrementally with each part able to be designed for the particular circumstances of that harm and the goals of further prevention or treatment. In a fully comprehensive scheme the arguments in favour of separation to enable improved prevention (even if the entitlements received are the same) remain valid. While a comprehensive compensation scheme would be good for working people, a comprehensive compensation scheme designed to serve the goals of prevention would be better. This thesis aims to achieve not only more coverage of work-related health problems but better coverage, ensuring better health and safety outcomes. 


\section{Conclusion}

This chapter has provided the drafting for the Work-Related Harm Part in the proposed new Act. This drafting reflects the approach to causation advocated in the previous chapter, shifting the focus of cover from "accidents" to the hazards of work. Underpinned by a labour law theoretical framework the drafting is intended to impact on a range of actors, influencing the prevailing thinking on work health and safety. The proposed test provides cover to a much wider range of work-related health problems, regardless of diagnostic categorisation, and also allows for changes in work and medical thinking to be responded to over time. The drafting does not define nor anticipate a particular form or manner of engagement to perform work, and the hazards listed are general and non-exhaustive. The drafting is intended to encourage decision-makers to frame analyses of cause in line with the explicit aims of recognising the rights of workers, ensuring comprehensive, fair and equitable cover, ensuring workers are treated with dignity and enabled to return to the fullest lives possible, as well as improving work health and safety. 


\title{
CHAPTER NINE: CONCLUSION
}

\author{
More Cover is Good: "Fewer Injuries and Illnesses" is Better
}

\section{Introduction}

The aim of this thesis was to propose a set of legislative reforms to improve the cover of work-related health conditions, and also improve work health and safety in New Zealand. The previous chapters have put forward a new approach to causation, with a set of drafted legislative provisions that reflect that approach. The provisions are intended to provide a practical and immediately implementable solution to the problems identified in the cover of work-related injuries and illnesses under the ACA. The thesis adopts a purposive labour law approach, as advocated by Davidov, to allow the "ends" of fair coverage and better health and safety to be reconnected with, and guide the design of, the legislative "means." Recognising the peculiar political development of the ACC scheme and its unique operation (compensating work-related injuries and illnesses as part of a wider scheme), the proposed reforms allow for the goals of the project to be met, without undermining the other functions, while also offering a path to further incremental expansions of cover in future. 


\section{The Aims of Reform}

This thesis started with an understanding of the historical and political context of the ACC scheme and the three major theoretical approaches to the compensation of work-related harm. Unlike previous examinations of the ACC scheme, this thesis takes a labour law approach and starts with a focus on health and safety and the prevention functions of the scheme. A labour law approach was adopted as it was the most consistent with the goals of the project, being improved cover for workers and improved work health and safety. Reflecting Davidov's purposive approach to labour law, the reform project started with an analysis of the ends sought, and an articulation of the principles, assumptions and values driving those ends. Key to this approach, the reason "why" workers should receive compensation is fundamental to determining "how" the scheme should be designed. The reforms were designed to aid in addressing the inherent inequality of bargaining power in the working relationship, recognise the wrongs of poor health and safety, and the rights of workers to safe and healthy work, as well as promoting equity and dignity in the operation of the compensation scheme. Clarity in principle is argued to provide the scheme with the best prospects of resolving the problems and also allowing the scheme to respond to challenges in future.

\section{The Reforms Proposed}

The reforms proposed can be summarised as follows:

1. The removal of "accident" as the underpinning rationale and entry point to cover under the scheme. This helps to remove the social and cultural baggage associated with the word "accident" from health and safety narratives.

2. A single dedicated Part within a new Act that provides cover to all work-related harms, regardless of diagnostic categorisation or causal mechanism. This approach sees the removal of the Occupational Diseases Schedule and the problematic sections $21 \mathrm{~B}, 28$ and 30.

3. A clear statement of purpose to guide determinations of cover and the future development of the scheme in responding to changing patterns of work and medical 
thinking. The purpose statement has been drafted to reflect the labour law goals of rights, equity, dignity and improved health and safety.

4. A new "purposive" test for cover, which allows for a wider range of causal relationships to be recognised, including Māori models of health. This test is intended to help shift the boundaries of what is considered "work-related", and as a result, the scope of the employer/PCBU's perceived responsibilities for health and safety.

5. New terminology that better aligns with health and safety promotion, and which should help to shift the narratives of work-related harm from the specifics of diagnosis to the hazards of work.

6. The extension of cover to a much wider range of work-related health problems, including chronic stress-related illnesses, and illnesses that involve more complex relationships of causation. This ensures that more workers are able to access treatment, rehabilitation and earnings-related compensation as the research in to work-related health grows. This expansion also includes health problems directly transmitted to a third-party through a worker, covering secondary victims of hazardous substance exposures and individuals with birth defects related to a parent's work.

7. The collection of wider and better data on work-related health conditions. A fuller statistical picture of work-related injury and illness in New Zealand is likely to result from expanded cover. The proposed hazard-based indicative list drives cover applications, and as a result the information provided, resulting in greater data on the hazards involved and the circumstances of worker exposure. This data allows for presently invisible conditions to become visible in future, allowing for greater research, and the development of better policy, enforcement and union action. 


\section{Limitations, Opportunities and Next Steps}

The scope of this thesis was limited to work-related injuries and illnesses. This thesis rests on the assumption that work-related injuries and illnesses arise in a different context to other forms of harm, and that this different context requires a different legislative response, even if the resulting entitlement is identical. Prevention activities, if they are to be effective, cannot be blind to the factors that cause the injuries and illnesses sought to be prevented. Work-related injuries and illnesses arise from the relations of work. The relations of work involve unequal levels of power and control over the hazards that result in injuries and illnesses, with decisions about health and safety directly linked to the profits generated through the performance of work. As such workers have rights and employers/PCBUs have duties that are different to those in other relationships. A compensation scheme should achieve more than just providing compensation, it should act as a positive force for the prevention of harm, influencing the behaviour of actors, framing the thinking on such conditions in a way that best creates an environment for prevention, and also collecting the data to allow for research, policy and enforcement activities.

There are, of course, other functions performed by the ACC scheme in need of reform. At the same time as research for this thesis was being carried out, Dunedin Barrister, Warren Forster, has been working on a significant project proposing to expand and fund the ACC scheme for the cover of non-accident, and non-work-related disabilities, giving effect to the United Nations Convention on the Rights of People with Disabilities. ${ }^{793}$ Forster's research is intended for publication late in 2019, providing a proposal for reform to cover incapacities unrelated to work. In 2017 a report was also published proposing an independent ombudsman or commissioner for the ACC scheme. ${ }^{794}$ The need for reforms to improve access to justice and ensure independent oversight affirmed by recent failures in relation to the independence of reviewers and ACC's selections of medical experts. ${ }^{795}$

\footnotetext{
${ }_{793}$ Forster, above at $\mathrm{n} 14$.

${ }^{794}$ Forster, Barraclough and Mijatov, above at $\mathrm{n} 9$.

${ }^{795}$ See Cate Broughton "ACC tells minister justice issues have been fixed, but advocates not so confident" (26 Feb 2019) < https://www.stuff.co.nz/national/health/110789966/acc-tells-minister-justice-issues-havebeen-fixed-but-advocates-not-so-confident>
} 
This thesis was written with an awareness of these pieces of work, and is intended to operate as part of a wider package of reforms needed to ensure the ACC scheme can fulfil its potential and meet the needs of all New Zealanders in future.

While this thesis argues for a unique response to work-related health problems, it does not seek to prevent further expansions to the ACC scheme, with the proposal for reforms drafted with the aim of either facilitating future (more prevention focussed) expansions through new Parts to the proposed new Act, or able to operate as a discrete Part in a new fully-comprehensive social insurance scheme. The proposal seeks to ensure that the unique needs of workers can be met, without undermining the worthy ambitions of the Woodhouse Report or denying the rights of other people suffering an incapacity. As Woodhouse himself recognised, the aims of prevention should always be paramount in any scheme.

The current Minister of Workplace Relations, Safety, and ACC, Iain Lees-Galloway, has indicated an intention to introduce ACC reform legislation late in 2019. Although the shape of this reform is yet to be released, the Minister has indicated publicly that reforms will not involve expansions to achieve the original Woodhouse vision. At the time of submission of this thesis, it was unclear whether the recommendations made in this thesis had been accepted by officials or the Minister for this round of reforms. Regardless, significant future reforms to the ACC scheme are likely, especially given Forster's research, the series of critical independent reports, and the near daily media coverage of ACC-related problems. ${ }^{796}$

The reforms proposed have been designed to contribute to improved health and safety, but a lot more is needed to address New Zealand's poor health and safety record and to ensure health and safety laws are operating optimally. For example, work health and safety in New Zealand could be improved though a stronger set of prescriptive regulations sitting beneath the HSWA, the development of approved codes of practice and guidelines on health promotion and psychosocial hazards monitoring, better enforcement practices and more

\footnotetext{
${ }^{796}$ The reports are cited above at $\mathrm{n} 9$.
} 
prosecutions, more suitable inspection tools for the hazards related to chronic work-related health problems, improved worker participation provisions, greater coordination between the sick leave provisions and work health promotion and greater numbers of properly trained inspectors. Improvements to health and safety, and a full response to work-related stress also requires addressing wider employment relations regulation, including the minimum standards for working practices, wages, redundancy compensation and restructuring protections.

This thesis has provided an analysis of the cover of work-related injuries and illness in New Zealand and proposes a set of reforms to improve cover and work health and safety. The proposed new Act, and the new Work-Related Harm Part within it, are intended to contribute to law reform efforts in New Zealand and the scholarship on workers' compensation and work health and safety. The proposed reforms can be understood as a contribution to improving work health and safety in New Zealand, which, if implemented, allows for better data on work-related health problems to inform future legal reforms, as well as creating a financially driven shift in the behaviour and language of actors, which hopefully makes other reforms easier in future. 


\section{BIBLIOGRAPHY}

\section{Cases}

\section{A New Zealand}

Aldridge v Accident Compensation Corporation [2007] NZACC 154.

Appleby v Accident Compensation Corporation [1985] NZACAA 3.

Attorney-General v Gilbert [2002] NZCA 55; [2002] 2 NZLR 342.

Brooker v Accident Compensation Corporation [2016] NZACC 186.

Campbell v Commissioner of Salford School [2015] NZEmpC 122.

Carter v Accident Compensation Corporation [2016] NZHC 1140.

Re Chase [1989] 1 NZLR 325 (CA).

Christian v Accident Compensation Corporation [2006] NZACC 133.

Clear v Waikato District Health Board [2007] NZERA 33.

Crutchley v Chief Executive of Ministry of Social Development [2008] NZERA 196.

Couch v Attorney-General (No 2) [2010] NZSC 27; [2010] 3 NZLR 149.

Department of Labour v Nalder \& Biddle (Nelson) Ltd [2005] NZHSE 20.

ETN v Accident Compensation Corporation [1998] NZACC 227.

Gable v Accident Compensation Corporation [2003] NZACC 212.

Hill v Accident Compensation Corporation [2016] NZACC 229.

Idea Services Ltd v Dickson [2011] NZCA 1; [2011] 2 NZLR 522.

KB v Accident Compensation Corporation [2013] NZACC 41.

Kidd v Beaumont [2016] NZEmp 158.

Kiney v Accident Compensation Corporation [1990] NZACAA 253.

Knox v Accident Rehabilitation and Compensation Insurance Corporation [2000] NZHC 1215.

Labour Inspector (MBIE) v Smiths City Group [2018] NZEmpC 43.

MacFarlane v Accident Compensation Corporation [2014] NZACC 147.

MC v Accident Compensation Corporation [2016] NZACC 264.

McGougan and Dingle v Depuy International Ltd [2016] NZHC 2511; [2017] 2 NZLR 119. 
Meikle v Accident Compensation Corporation [2008] NZACC 158.

OSC Ltd v TW [2013] NZACC 177.

Osborne and Rockhouse v WorkSafe [2017] NZSC 175; [2018] 1 NZLR 447.

Ovation New Zealand Ltd v New Zealand Meat Workers Trades Union Inc [2018]

NZEmpC 151.

Purdie v Accident Compensation Corporation [2010] NZACC 13.

Rosenberg $v$ Air New Zealand Ltd [2009] NZERA 556.

Salad Bowl Ltd v Howe-Thonley [2013] NZEmpC 152; [2013] ERNZ 326.

Slayman v Accident Compensation Corporation [2013] NZACC 236.

South Canterbury District Health Board v Sanderson [2017] NZEmpC 127.

Teen v Accident Compensation Corporation and Telecom Ltd [2002] NZACC 244.

Wakenshaw v Accident Compensation Corporation [2003] NZHC 1005.

Estate of Wei v Accident Compensation Corporation [2004] NZACC 338.

Wilding v Attorney-General [2003] NZCA 205; [2003] 3 NZLR 787.

Yeoman v Accident Compensation Corporation [2008] NZACC 191.

\section{B Australia}

Kennedy Cleaning Services v Petkoska [2000] HCA 45.

May v Military Rehabilitation and Compensation Commission [2015] FCAFC 93.

Military Rehabilitation and Compensation Commission v May [2016] HCA 19.

Su v Comcare [2011] AATA 934.

Telstra Corporation Ltd v Smith [2009] FCAFC 103.

\section{Legislation}

\section{A New Zealand}

Accident Compensation Act 1972.

Accident Compensation Act 1982.

Accident Compensation Act 2001.

Coal Mines Act 1891.

Employer Liability Act 1882.

Employment Relations Act 2000. 
Health Act 1956.

Health and Safety at Work Act 2015.

Interpretation Act 1999.

Radiation Safety Act 2016.

Regulation of Mines Act 1874.

Workers' Compensation Act 1956.

Workers' Compensation for Accidents Act 1900.

\section{B Australia}

Australian National Compensation Bill (Cth).

Model Work Health and Safety Bill.

Safety, Rehabilitation and Compensation Act 1988 (Cth).

\section{United Kingdom}

Employer's Liability (Compulsory Insurance) Act 1969.

Workmen's Compensation Act 1897.

\section{Regulations}

Hazardous Substances (Classification) Notice 2017.

Health and Safety at Work (Asbestos) Regulations 2016.

Health and Safety at Work (General Risk and Workplace Management) Regulations 2016.

Health and Safety at Work (Hazardous Substances) Regulations 2017.

Health and Safety at Work (Major Hazard Facilities) Regulations 2016.

Health (Diseases Communicated by Animals) Regulations 1965.

Health (Infectious and Notifiable Diseases) Regulations 2016.

\section{International Treaties and Conventions}

ILO Declaration of the Fundamental Principals and Rights at Work - (adopted by the International Labour Conference at its Eighty-sixth Session, Geneva, 18 June 1998 (Annex revised 15 June 2010). 
ILO Declaration on Social Justice for a Fair Globalisation (Resolution adopted at the 63rd session of the United Nations General Assembly, 2008).

ILO Istanbul Declaration on Safety and Health at Work (Issued XIX World Congress on Safety and Health at Work, 11 September 2011).

ILO Seoul Declaration on Safety and Health at Work (XVIII World Congress on Safety and Health at Work, 29 June 2008).

International Covenant on Economic, Social and Cultural Rights GA Res 2200A (XXI) (1966).

Universal Declaration of Human Rights GA Res 217A (1948).

ILO Absolute Liability Workers' Compensation -Employment Injury Benefits Convention 121 (1964).

\section{Books}

American Psychological Association Diagnostic and Statistical Manual of Mental Disorders (4 ${ }^{\text {th }}$ ed, American Psychological Association, Washington DC, 1994).

Keith Allen and Tom Stoneham Causation in modern philosophy (Routledge, New York 2011).

Philip Alston Labour Rights as Human Rights (Oxford University Press, Oxford, 2008).

Gordon Anderson Reconstructing New Zealand's labour law, consensus or divergence? (Victoria University Press, Wellington, 2011).

Gordon Anderson, Alan Geare, Erling Rasmussen and Margaret Wilson (eds) Transforming Workplace Relations in New Zealand 1976-2016 (Victoria University Press, Wellington, 2017).

Hazel Armstrong Blood on the Coal: The Origins and Future of New Zealand's Accident Compensation Scheme (Trade Union History Project, Wellington, 2008).

Christopher Arup, Peter Gehan, John Howe, Richard Johnstone, Richard Mitchell and Anthony O'Donnell (eds) Labour Law and Labour Market Regulation (Federation Press, Sydney, 2006).

Indira Ashton and Frank S Gill Monitoring for Health Hazards at Work (3 $3^{\text {rd }}$ ed, Blackwell, Oxford, 2000). 
I Ayres and J Braithwaite Responsive Regulation: Transcending the Deregulation Debate (Oxford University Press, Oxford, 1992).

Salvatore Babones Social Inequality and Public Health (Policy Press, Bristol, 2009).

Bob Barnetson The Political Economy of Workplace Injury in Canada (Athabasca University Press, 2010).

Helen Beebee (ed) Making a difference: Essays in the philosophy of causation (Oxford University Press, Oxford, 2017)

Liz Bluff, Neil Gunningham and Richard Johnstone (eds) OHS Regulation for a Changing World of Work (Federation Press, Sydney, 2004).

Micheal Bracken Risk, chance and causation: Investigating the origins and treatments of disease (New York, Yale University Press, 2013)

L Brea Genetics, Health and Society (Emerald Group, Bingley, 2015).

William Breen Creighton, William Ford and Richard Mitchell Labour Law: Text and Materials (2 ${ }^{\text {nd }}$ ed, Law Book Co, Sydney, 1993).

Ian Campbell Compensation for personal injury in New Zealand: Its rise and fall (Auckland University Press, Auckland, 1996).

Kay Codell Carter The rise of causal concepts of disease: case histories (Ashgate, Burlington, 2003).

J Conaghan, M Fischl and K Klare Labour law in an era of globalization: Transformative practices and possibilities (Oxford University Press, Oxford, 2002).

Hugh Collins, Gillian Lester and Virginia Mantouvalou (eds) Philosophical Foundations of Labour Law (Oxford University Press, Oxford, 2018).

Guy Davidov A Purposive Approach to Labour Law (Oxford University Press, Oxford, 2016).

Guy Davidov and Brian Langille (eds) Boundaries and Frontiers of Labour Law: Goals and Means in the Regulation of Work (Hart, Portland and Oxford, 2006).

Guy Davidov and Brian Langille (eds) The Idea of Labour Law (Oxford University Press, Oxford, New York, 2011).

Guy Davidov and Brian Langille Boundaries and frontiers of labour law: Goals and means of work regulation (Hart, Oxford and Portland, 2006).

Richard Donkin The History of Work (Palgrave Macmillan, New York, 2010). 
Ruth Dukes The Labour Constitution: The Enduring Idea of Labour Law (Oxford University Press, Oxford, 2014).

Josef Ehmer and Catharina Lis The Idea of Work in Europe from Antiquity to Modern Times (Ashgate, Surrey, 2009).

Judy Fudge, Shae McCrystal and Kamala Sankaran Challenging the Legal Boundaries of Work Regulation (Hart, Oxford and Portland, 2012).

Peter Goldie The Mess Inside: Narrative, Emotion and the Mind (Oxford University Press, Oxford, 2012)

Francis Green Demanding work: The paradox of job quality in the affluent economy (Princeton Uni Press, e Book, 2006).

A F Griffiths, J H Miller, D T Suzuki An Introduction to Genetic Analysis (7th ed.

Freeman, New York, 2000).

HLA Hart and Tony Honoré Causation in the law (2nd ed, Oxford, Oxford University

Press, 1985).

Douglas Hay and Paul Craven (eds) Masters, Servants and Magistrates in Britain and the Empire 1562-1955 (University of North Carolina Press, New York, 2004).

P Hjemdahl, A Steptoe, A Rosengren (eds) Stress and Cardiovascular Disease (Springer, London, 2011).

Christopher Hoerl, Teresa McCormack and Sarah Beck Understanding counterfactuals: Understanding causation issues in philosophy and psychology (Oxford University Press, Oxford, 2011).

RP Hudson The Cambridge World History of Disease (Cambridge University Press, Cambridge, 1993).

Terence Ison The Forensic Lottery: A Critique on Tort Liability as a System of Personal Injury Compensation (Staples Press, London, 1967).

Richard Johnstone, Elizabeth Bluff and Alan Clayton Work Health and Safety Law and Policy ( $3^{\text {rd }}$ ed, Thompson Reuters, Pyremont, 2012).

Min Soo Jung An investigation of the causal inference between epidemiology and jurisprudence (Singapore, Springer, 2018).

Arne Kalleberg and Steven Vallas (eds) Vol 31 Precarious Work (Book series on the sociology of work) (Emerald Insights, e-book, 2017). 
Christian Korunka and Bettina Kubicek (eds) Job demands in a changing world of work (Springer, eBook, 2017).

Myra Kunowski The first hundred years: Social welfare in New Zealand from 1891 (Heinemann Educational, Auckland, 1988).

Stavroula Leka and Jonathan Houdmont Occupational Health Psychology (WileyBlackwell, Sussex, 2010).

Ulf Lundberg and Cary L Cooper The Science of Occupational Health: Stress, Psychobiology and the New World of Work (Wiley-Blackwell, Online, 2010.

David Lyon (ed) Surveillance as social sorting: Privacy, risk and discrimination (Routledge, London, 2003).

Deirdre McCann Regulating Flexible Work (Oxford University Press, Oxford, 2008).

D H Mellor The Facts of Causation (Taylor and Francis, London, 1998).

Satish Mittal Coronary Heart Disease in Clinical Practice (Springer, London, 2005).

Rob Merkin and Jenny Steele Insurance and the Law of Obligations (Oxford University Press, Oxford, 2013).

Stephen Mumford and Rani Lill Anjum Causation: A very short introduction (E-book, Oxford University Press, 2013)

Theo Nichols The Sociology of Industrial Injury (Mansell Publishing, London, 1997).

Geoffrey Palmer Compensation for Incapacity: A Study of Law and Social Change in New Zealand and Australia (Oxford University Press, Wellington, 1979).

Pamela Perrewé, Jonathon Halbesleben and Chris Rose (eds) Book Series: Research in Occupational Stress and Well-being (Emerald Insights, e-book, 2010).

A Rabinovich The human motor: Energy, fatigue, and the origins of modernity (Harper Collins, New York, 1990).

Paul Ransome The Work Paradigm (Ashgate, Hunts, 1996).

Paul Ricoeur Time and Narrative (University of Chicago Press, Chicago, 1984)

Soo Hyun Rhee and Angelica Ronald Behaviour Genetics of Psychopathology (Springer, New York, 2014).

Mark A Robinson Accident compensation in Australia: No fault schemes (Legal Books, Sydney, 1987). 
Hartmut Rosa Social acceleration: A new theory of modernity (Columbia University Press, Boston, 2015).

Robert Sapolsky Why Zebras Don't Get Ulcers (Freeman, New York, 2004)

G Schmorl and H Junghanns The Human Spine in Health and Disease (Grune and Stratton, New York, 1971).

M Seligman Helplessness: On depression, development and death (Freeman, San Francisco 1975).

Hans Selye Stress (Acta Medical Publisher, Quebec, 1950).

Andrew Sharp The welfare tradition: Social welfare, New Zealand since 1891 (Heinemann Educational, Auckland, 1975).

Regis A de Silva Heart Disease (biographies of disease series)( ABC-CLIO, e-book, 2013). Guy Standing The Precariat: The Rise of the New Dangerous Class (Bloomsbury, London, 2011).

Sandy Steel Proof of causation in tort law (Cambridge University Press, Cambridge, 2015). Katherine Stone From widgets to digits: Employment regulation for a changing workplace (Cambridge University Press, Cambridge, 2004).

P Sterling, J Eyer and S Fisher (eds) Handbook of life stress, cognition and health (John Wiley, New York, 1988).

A Supiot Beyond employment: Changes in work and the future of labour law in Europe (Oxford University Press, Oxford, 2001).

Harvey Teff Causing Psychiatric and Emotional Harm: Reshaping the Boundaries of Legal Liability (Hart, Oxford and Portland, 2009).

Michael Waldermann (ed) The Oxford handbook of causal reasoning (ebook, Oxford University Press, 2017).

Richard Wilkinson and M G Marmot Social Determinants of Health ( $^{\text {nd }}$ ed, Oxford University Press, Oxford, 2006).

Peter W F Wilson Atlas of Atherosclerosis: Risk factors and treatment (Springer Science and Business Media, ebook, 2013).

Alex Zautra Emotions, Stress, and Health (Oxford University Press, Oxford, 2003). 


\section{A Chapters in Books}

R Blanpain "Comparitivism in Labour Law and Industrial Relations" in Comparative Labour Law and Industrial Relations in Industrialised Market Economies (Kluwer, The Netherlands, 2010).

Philip Bohle "Work Psychology and the Management of Occupational Health and Safety: An Overview" in Michael Quinlan (ed) Work and Health: The Origins, Management and Regulation of Occupational Illness (Macmillan, Melbourne, 1993).

Jane Bryson "Administering workplace relationships: From IR to HR" in Gordon Anderson, Alan Geare, Erling Rasmussen and Margaret Wilson (eds) Transforming Workplace Relations in New Zealand 1976-2016 (Victoria University Press, Wellington, 2017).

Mark Cullen, Linda Rosenstock and Edwin Kilbourne "Introduction to Occupational and Environmental Medicine" in Linda Rosenstock, Mark Cullen, Carl Brodkin and Carrie Redlich Textbook of Clinical Occupational and Environmental Medicine (2 ${ }^{\text {nd }}$ ed) (Elsevier Saunders, Philadelphia, 2005).

A Ericsson, EA Mayer, CB Saper, PE Sawchenko and HY Li "Circuits and mechanisms governing hypothalamic responses to stress: A tale of two paradigms" in A Ericsson, EA Mayer, CB Saper (eds) The Biological Basis for Mind Body Interactions (Vol 6, 122 ed, Elsevier Science, Amsterdam, 2000)

Judy Fudge "Labour as a 'fictive commodity': Radically Reconceptualising Labour Law" in Guy Davidov and Brian Langille, The Idea of Labour Law (Oxford University Press, Oxford, New York, 2011).

Antony Honoré "Principles and values underlying the concept of causation in law" in Ian Freckleton and Danuta Mendelson Causation in Law and Medicine (Ashgate Publishing, Aldershot, 2002).

D Ignatavicius, ML Workman "Chapter 3: Assessment and care of patients with pain" in D Ignatavicius, ML Workman Medical-surgical nursing: Patient-centered collaborative care (8th ed, Elsevier, St Louis, 2016).

Junko Kitanaka "Depression as a problem of labour: Japanese debates about work, stress, and a new therapeutic ethos" in Jerome Wakefield and Steeves Demazeaux (eds) Sadness or Depression? (Springer, e-book, 2016). 
VA Leary "The Paradox of Workers' Rights as Human Rights" in LA Compa and SF Diamond (eds) Human Rights, Labor Rights, and International Trade (University of Pennsylvania, Philadelphia, 1996).

Virginia Mantouvalou "Human Rights and the Contract of Employment" in Mark Freedland (ed) The Contract of Employment (Oxford University Press, Oxford, 2016). Mantouvalou "The right to non-exploitative work" in Virginia Mantouvalou (ed) The Right to Work: Legal and Philosophical Perspectives (Hart, Oxford, 2015).

M Marmot and A Feeney "Health and socioeconomic status" in G Fink (ed) Encyclopaedia of Stress (Academic Press, San Diego, 2000).

K Matthews "Summary, conclusions and implications" in K Mathews, S Weiss and T Detre (eds) Handbook of stress, reactivity and cardiovascular disease (Wiley Interscience, New York, 1986).

H N McTyiere "Duties of Masters to Servants" in Duties of Masters to Servants: Three Premium Essays (Southern Baptist Publications, 1851).

Dietrich Milles "From Workers' Diseases to Occupational Diseases: The Impact of Experts' Concepts on Workers Attitudes" in Paul Weindling (ed) The Social History of Occupational Health (Croom Helm, Kent, 1985).

H Nakai "Saiken no rinri to shite no kinbun to kufu" [Diligence and innovation as an ethic of reconstruction] in Y Kasahara (ed) Soutsubyo no seishinbyori I [Psychopathology of depression I] (Kobundo, Tokyo, 1976).

Matea Paskvan and Bettina Kubicek "The intensification of Work", in Christian Korunka and Bettina Kubicek (eds) Job demands in a changing world of work (Springer, eBook, 2017).

Lado Ruzicka "Issues in Occupational Mortality of Women" and Karen Messing and Jeanne Megar Stellman "Understanding Occupational Disease in Women Workers" in Penny Kane (ed) Women and Occupational Health (World Health Organisation, New York, 1997).

Paul Roth "Chapter 13 Economic Rights: Workplace Rights and the Right to Social Security" in Margaret Bedggood (ed) Human Rights Law in Aotearoa New Zealand (Thomson Reuters, Wellington, 2017). 
Dennis Smith "Causality and Spinal Pain: The Problem of Back Pain" in Ian Freckleton and Danuta Mendelson Causation in Law and Medicine (Ashgate Publishing, Aldershot, 2002).

Jane Stapleton "Scientific and legal approaches to causation" in Ian Freckelton and Danuta Mendelson Causation in Law and Medicine (Routledge, New York, 2002).

Ernest J Weinrib "47. Unjust enrichment" in Dennis Petterson (ed) A companion to philosophy of law and legal theory (Blackwell, Online, $\left.2^{\text {nd }} \mathrm{ed}, 2010\right)$.

\section{Journal Articles}

Patricia Alach and Kerr Inkson “The New 'Office Temp': Alternative Models of Contingent Labour" (2004) 29(3) NZJER 37.

Einat Albin "The missing context: Comments on a purposive approach to labour law" (2017) 16(1) Jerusalem Rev Leg Stud 15.

A Alkon, L Goldstien, N Smider, M Essex, D Kupfer and W Boyce "Developmental and contextual influences on autonomic reactivity in young children" (2003) 42 Developmental Psychobiology 64.

M Allen and K Matthews "Hemodynamic responses to laboratory stressors in children and adolescents: The influence of ages, race and gender" (1997) 34 Psychophysiology 730.

Swaen G van Amelsvoort "A weight of evidence approach to causal inference" (2009) 62(3) J Clin Epidemiol 270.

Gordon Anderson, Peter Gehan, Richard Mitchell and Andrew Stewart "The Evolution of Labour Law in New Zealand: A Comparative Study of New Zealand, Australia and Five Other Countries” (2011) 33(1) Comp Labor Law Pol’y Journal 137.

L Artazcoz, J Benach, C Borell and I Cortes "Social inequalities in the impact of flexible employment on different domains of pstchosocial health" (2005) 59 J Epid Comm Health 761.

Harry Arthurs "Can Davidov's slingshot slay the Goliath of political economy? On Guy Davidov's purposive approach to labour law" (2017) 6(1) Jerusalem Rev Leg Stud 1. Harry Arthurs "Charting the boundaries of labour law: Innes Christie and the search for an integrated law of labour market regulation" (2011) 34(1) Dalhousie L J 1. 
Brenda Barrett and David Lewis “Is the Employer's Liability (Compulsory Insurance) Act 1969 Fit for Purpose?” (2016) 45(4) ILJ 503.

Jonathan Barrett and Leigh Thomson "Returning Dignity to Labour: Workplace Safety as a Human Right" (2012) 37(1) NZJER 82.

M Battie, T Videman, J Kaprio "The twin spine study; Contributions to a changing view of disc degeneration" (2009) 9 The Spine Journal 47.

Nicole Baumann and Jean-Claude Turpin "Neurochemistry of Stress. An Overview" (2010) 35 Neurochem Res 1875.

B Baune, R Caniato, M Garcia-Alcaraz and K Berger "Combined effects of major depression, pain and somatic disorders on general functioning in the general adult population" (2008) 138 Pain 310.

J Boekhorst, P Singh and R Burke, "Work intensity, emotional exhaustion and life satisfaction: The moderating role of psychological detachment" (2017) 46(5) Personnel Review 891.

Alan Bogg "Labour, Love and Futility: Philosophical Perspectives on Labour Law (2017) 33 Int J of Comp L L I R 7.

H Bosma, M Marmot, H Hemingway, A Nicholson, E Brunner, S Stansfeld "Low job control and risk of coronary heart disease in the Whitehall II (prospective cohort) study" (1997) 314 BMJ 558.

DB Boivin, GM Tremblay and FO James "Working on atypical schedules" (2007) 8(6) Sleep Med 578.

Thomas Boyce and Bruce Ellis "Biological sensitivity to context: An evolutionarydevelopmental theory of the origins and functions of stress reactivity" (2005) 17 Development and Psychology 271.

Brian Bride and Charles Figley, "The fatigue of compassionate social workers: An introduction to the special issue on compassion fatigue"(2007) 35 Clin Soc Work J 151. T Britt "Engineering the self in the field: Testing the triangle model of responsibility" (1999) 25 Personality and Psychology Bulletin 696.

T Britt "Aspects of identity predict engagement in work under adverse conditions" (2003) 2 Self and Identity 31. 
David Brougham and Jarrod M. Haar "Collectivism, Cultural Identity and Employee Mental Health: A Study of New Zealand Māori” (2013) 114(3) Social Indicators Research 1143.

John Burgess, Erling Rasmussen and Julia Connell "Temporary Work in Australia and New Zealand: Out of Sight and Outside the Regulatory Net" (2004) 29(3) NZJER 25.

J Cacioppo, G Berntson, W Malarkey, J Kiecolt-Glaser, J Sheridan, K Poehlmann, M Burleson, J Ernst, L Hawley and R Glaser "Autonomic, neuroendocrine, and immune responses to psychological stress: The reactivity hypothesis" (1998) 840 Annals of the New York Academy of Sciences 664.

Rafealla Campaner "Philosophical theories of causation for epidemiology" (2010) 34(1) Epedemiogia e prevenzione 48.

Jim Campbell, Suzanne Ross and Emily Thomson "Recession and recovery in Scotland: The impact of women's labour force participation beyond the headline statistics" (2017) 7(1) Journal of Gender Studies 123.

Catarina Caniveta, Gunnar Aronsson, Claudia Bernhard-Oettel, Constanze Leineweber, Mahnaz Moghaddassia, Johanna Stengård, HugoWesterlund Per-Olof Östergrena "The negative effects on mental health of being in a non-desired occupation in an increasingly precarious labour market" (2017) 3 SSM - Population Health 516.

Walter Cannon "Stress and Strains of homeostasis" (1935) 189 Am J Med 1.

A Cattaneo and M Riva "Stress induced mechanisms and mental illness: A role for glucocorticoid signalling" (2016) 160 Journal of Steroid Biochemistry and Molecular Biology 169.

Tarani Chandola, Annie Britton, Eric Brunner, Harry Hemingway, Marek Malik, Meena Kumari, Ellena Badrick, Mika Kivimaki, and Michael Marmot "Work stress and coronary heart disease: What are the mechanisms?" (2008) 29 European Heart Journal 640.

T Chandola T, P Martikainen, M Bartley, E Lahelma, M Marmot, S Michikazu, A Nasermoaddeli, S Kagamimori "Does conflict between home and work explain the effect of multiple roles on mental health? A comparative study of Finland, Japan, and the UK" (2004) 33(4) Int J Epidemiol 884.

JD Chen, YC Lin and ST Hsiao "Obesity and high blood pressure of 12-hour night shift female clean-room workers" (2010) 27(2) Chronobiol Int 334. 
James Chowhan, Margaret Denton, Catherine Brookman, Sharon Davies, Firat K. Sayin, Isik Zeytinoglu "Work intensification and health outcomes of health sector workers" (2019) Personnel Review 48(2) 342.

GP Chrousos and PW Gold "The concepts of stress and stress system disorders: overview of physical and behavioral homeostasis" (1992) 267 JAMA 124.

Eean Crawford and Jeffry LePine "Linking job demands and resources to employee engagement and burnout: A theoretical extension and meta-analytic test" (2010) 95 Journal of Applied Psychology 834.

David Crossman "The pathophysiology of myocardial ischaemia" (2004) 90(5) Heart 576. Nadia Dabee "A new paradigm for health and safety: Is it time to abandon experiencerating once and for all?" (2017) 42(1) NZJER 72.

Rohhveig Dahle "Social work: A history of gender and class in the profession" (2012) 12(3) Ephemera 309.

R Davidson, D Jackson and N Kalnin "Emotion, plasticity, context, and regulation: Perspectives from affective neuroscience" (2000) 126 Psychological Bulletin 890.

Guy Davidov "Setting Labour Law's Coverage: Between Universality and Selectivity" (2014) 34(3) Oxf J Leg Stud 543.

Guy Davidov “The (changing?) idea of labour law” (2007) 146 3/4 Int'1 Lab Rev 311.

Simon Deakin "Labour law: The pragmatists guide - Comments on Guy Davidov's A purposive Approach to Labour Law" (2017) 16(1) Jerusalem Rev Leg Stud 28.

Phil Dowe "The conserved quantity theory of causation and chance raising" (1998) 44 Philosophy of Science 486.

N Dragano, P Verde and J Siegrist "Organisational downsizing and work stress: Testing synergistic health effects in employed men and women" (2005) 59 Journal of Epidemiology and Community Health 694.

N Dragano, Y He, S Moebus, KH Jo"ckel, E Erbel and J Siegrist "Heinz Nixdorf Recall Study Two models of job stress and depressive symptoms. Results from a population-based study" (2008) 43(1) Soc Psychiatry Psychiatr Epidemiol 72.

W Drevets "Neuroimaging and neuropathological studies of depression: Implications for the cognitive-emotional features of mood disorders" (2001) 11 Current Opinion in Neurobiology 240. 
Brian Easton "The Historical Context of the Woodhouse Commission" (2003) 34 VUW Law Rev 293.

$\mathrm{N}$ Eisenberger, M Leiberman and K Williams "Does rejection hurt? An fMRI study of social inclusion" (2003) 320 Science 290.

Deborah Ellison "Critical Care Nursing" (2017) 29(4) Clinics of North America 397.

Amanda Eng, Andrea't Mannetje, Lis Ellison-Loschmann, Dave McLean, Soo Cheng and

Neil Pearce "Ethnic differences in patterns of occupational exposures in New Zealand" (2011) 54 American Journal of Industrial Medicine 410.

Cynthia Estlund "The Death of Labour Law" (2006) 2 Annual Review of Law and Social Sciences 105.

Cynthia Estlund "The Ossification of American Labour Law" (2007) 102 Columbia Law Rev 1527.

Keith Ewing “The Death of Labour Law” (1988) 8 Oxford J Legal Stud 293.

Annie Fahy "The Unbearable Fatigue of Compassion: Notes from a substances counselor who dreams of working at Starbucks" (2007) 35 Clin Soc Work J 199.

Erich C Fein, Natalie Skinner and M. Anthony Machin "Work Intensification, Work-Life Interference, Stress, and Well-Being in Australian Workers" (2017) 47(4) International Studies of Management \& Organization 360.

R Foster and K Wulff "The rhythm of rest and excess" (2005) 6(5) Nat Rev Neurosci 407.

F Franke "Is work intensification extra stress?" (2015) 14(1) Journal of Personnel Psychology 17.

Gerald Friedman "Workers without employers: Shadow corporations and the rise of the gig economy" (2014) Review of Keynesian Economics 171.

T Frodl, M Szyf, A Carbelledo, M Gill, L Booij "Integrated functional imaging and genetics in depression and anxiety" (2015) 30 European Psychiatry 119.

Judy Fudge "Regulating for decent work in a global economy" (2018) 43(2) NZJER 10. Judy Fudge, Eric Tucker and Leah Vosko "Changing boundaries in employment: Developing a new platform for labour law" (2003) 10 CLELJ 329.

Judy Fudge "Reconceiving employment standards legislation: Labour law's little sister and the feminization of labour [law]" (1991) 7 J L \& Soc Pol'y 73. 
Judy Fudge "Feminist reflections on the scope of labour law: Domestic work, social reproduction and jurisdiction" (2014) 22(1) Fem Leg Stud 23.

Karen L Gamble, David Resuehr and Carl Hirschie "Shift work and circadian dysregulation of reproduction" (2013) 4(92) Front Endocrinol 1.

JE Gangwisch, SB Heymsfield and B Boden-Albala "Short sleep duration as a risk factor for hypertension: Analyses of the first National Health and Nutrition Examination Survey" (2006) 47(5) Hypertension 833.

JE Gangwisch, SB Heymsfield and B Boden-Albala "Sleep duration as a risk factor for diabetes incidence in a large U.S. sample” (2007) 30(12) Sleep 1667.

Harry Glasbeek "Occupational Health and Safety Law: Criminal Law as a Political Tool” (1998) 11 AJLL 95.

B J Gilpin, P Scholes, and B Robson "The transmission of thermotolerant Campylobacter spp. to people living or working on dairy farms in New Zealand" (2008) 55 Zoonoses

Public Health 352.

John Gould "Maori-Pakeha occupational segregation and earnings differentials: A comment” (2003) 29(2) New Zealand Population Review 1.

Guillaume Goyette-Desjardins, Jean-Philippe Auger, Jianguo Xu, Mariela Segura and Marcelo Gottschalk "Streptococcus suis, an important pig pathogen and emerging zoonotic agent — an update on the worldwide distribution based on serotyping and sequence typing" (2014) 3(6) Emerg Microbes Infect e45.

O Gureje, M Von Korff, and L Kola et al "The relation between multiple pains and mental disorders: Results from the world mental health survey" (2008) 135 Pain 82.

O Gureje, M Von Korff, and L Kola et al "The relation between multiple pains and mental disorders: Results from the world mental health survey" (2008) 135 Pain 82. Francis Green "Work intensification, discretion, and the decline in well-being at work" (2004) 30(4) Eastern Economic Journal 615.

Gehan Gunasekara "Making a difference? The Privacy Act and employment relationship problems in New Zealand (2018) 28 NZULR 25.

Neil Gunningham “Lessons from Pike River: Regulation, safety and neoliberalism” (2015) 26(4) NZULR 736.

Gregory Guyton “A brief history of workers’ compensation” (1999) 19 Iowa Orthop J 106. 
E S Hanson "The proportionate mortality ratio and its relationship with measures of mortality" (1990) 9(3) Stat Med 315.

Goran Hansson "Inflammation, atherosclerosis, and coronary artery disease" (2005) 352 N Eng J Med 1685.

K Hawkin "Compliance strategy, prosecution policy and aunt Sally: A comment on Pearce and Tombs" (1990) 30(4) Brit J of Criminol 444.

H Hemingway, M Shipley, E Brunner, A Britton, M Malik and M Marmot "Does autonomic function link social position to coronary risk? The Whitehall II study" (2005) 111 Circulation 3071.

Ingrid Heuch, Ivar Heuch, Knut Hagen and John-Anker Zwart "Physical activity level at work and risk of chronic low back pain: A follow-up in the Nord-Trøndelag Health Study" PLoS ONE 12(4) e0175086.

Jeffrey Hilgert "The future of workplace health and safety as a fundamental human right" (2013) 33 Comp Lab Law \& Pol'y J 715.

Paul Himmelstein "Reproductive hazards in the workplace: what the practitioner needs to know about chemical exposures" (1988) 71(6) Obstet Gynecol 921.

LB Holmes "Impact of the detection and prevention of developmental abnormalities in human studies" (1997) 11 Reprod Toxicol 267.

Richard Holtad, David Phillips, Karen Jameson, Cyrus Cooper, Elaine Dennisona and Robert Pevelerc "The relationship between depression, anxiety and cardiovascular disease: Findings from the Hertfordshire Cohort Study" (2013) 150(1) Journal of Affective Disorders 84.

C Houkamau and C Sibley "Māori cultural efficacy and subjective wellbeing: A psychological model and research agenda” (2011) 103(3) Social Indicators Research 379.

Douglas Hyers and Maria Kovacova "The economics of the online gig economy: Algorithms, hiring practices, and rights for platform workers" (2018) 6(1) Psychological Issues in Human Resources Management 160.

Terence G Ison “Reflections on the State of Workers' Compensation and Occupational Health and Safety in the United States of America and Canada" (2015) 47(1) Compensation and Benefits Review 27. 
Terence G Ison "A historical perspective on contemporary challenges in workers' compensation" (1996) 34 Osgoode Hall L J 807.

Susan Jackson and Christina Maslach "After effects of job-related stress: Families as victims" (1981) 3 Journal of Occupational Behaviour 63.

Richard Johnstone "Work health and safety and the criminal law in Australia" (2013) 11(2) Policy and Practice in Health and Safety 25.

W Kahn "Psychological conditions of personal engagement and disengagement at work" (1990) 33 Academy of Management Journal 692.

Otto Kahn-Freund "On Uses and Misuses of Comparative Law" (1974) 37(1) MLR 1.

RA Karasek "Job demands, job decision latitude, and mental strain: implications for job redesign" (1979) 24 Admin Sci Q 285.

Y Kasahara "Utsubyo no shoseishinryoho" [brief psychotherapy for depression] (1978) 4(2) Kikan Seishinryoho [Japanese Journal of Psychiatry] 6.

A E Kazdin "The meanings and measurement of clinical significance" (1999) 67(3) Journal of consulting and clinical psychiatry 332 .

R E Kendell "The distinction between mental and physical illness" (2001) 178 BJP 490.

K Kendler, C Prescott, J Myers and M Neale "The structure of genetic and environmental risk factors for common psychiatric and substance use disorders in men and women" (2003) 60 Archives of General Psychiatry 929.

G Klous, A Huss, DJJ Heederik and RA Coutinho "Human-livestock contacts and their relationship to transmission of zoonotic pathogens, a systematic review of literature" (2016) 2 One Health 65.

Grace Khunou, Roshini Pillay and Angela Nethononda "Social work is women's work: An analysis of social work student's perceptions of gender as a career choice determinant" (2012) 24(1) The Social Work Practioner-Researcher 120.

W Kim "Economic crisis, downsizing and "layoff survivor's syndrome"” (2003) 33 Journal of Contemporary Asia 449.

Eun-A Kim and Seong-Kyu Kang "Historical review of the List of Occupational Diseases recommended by the International Labour organization (ILO)" (2013) 25 Annals of Occupational and Environmental Medicine 14. 
Junko Kitanaka "The rebirth of secrets and the new care of the self in depressed Japan" (2015) 56(12) Current Anthropology S251.

Robert W Klein and Gregory Krohm "Alternative funding mechanisms for workers' compensation: An international comparison" (2006) 59(4) International Social Security Review 3.

Darl Kolb, Paul Collins and Allan Lind "Requisite connectivity: Finding flow in a not-soflat world" (2008) 37(2) Organisation Dynamics 181.

K Kolben “Labor Rights as Human Rights?” (2010) 2 Va J Int'1 Law 449.

B Kubicek, M Paškvan and C Korunka "Development and validation of an instrument for assessing job demands arising from accelerated change: The intensification of job demands scale (IDS)" (2005) 24(6) European Journal of Work and Organizational Psychology 898. S Kunz-Ebrecht, C Kirschbaum, A Steptoe "Work stress, socioeconomic status and neuroendocrine activation over the working day" (2004) 58(1523 Soc Sci Med 642.

J Ryan Lamare, Felicity Lamm, Nadine McDonnell and Helen White "Independent, dependent and employee: Contractors and New Zealand's Pike River Coal Mine disaster" (2015) 57(1) JIR 72.

Felicity Lamm, Kaj Frick, Suzanne Jamieson, Christophe Martin and Nadine McDonnell "Managing occupational safety and health in culturally diverse small businesses: a commentary" (2013) 11(1) Policy and Practice in Health and Safety 3.

Felicity Lamm and Marjolein Lips-Wiersma "A disaster waiting to happen: Silently silencing stakeholders at the Pike River Coal Mine" (2018) 60(4) JIR 560.

Felicity Lamm, Claire Massey and Martin Perry "Is there a link between workplace health and safety and firm performance and productivity" (2006) 32(1) NZJER 75.

Felicity Lamm, Nadine McDonnell and Susan St John “The rhetoric versus the reality: New Zealand's Experience Rating" (2012) 38(2) NZJER 21.

A LaMontagne, $\mathrm{K}$ Sanderson and F Cocker "Estimating the Economic Benefits of Eliminating Job Strain as a Risk Factor for Depression" (2011) 68 Occupational and Environmental Medicine A3.

Christina Lawson, Teresa Schnorr, George Daston, Barbara Grajewski, Michele Marcus, Melissa McDiarmid, Eisuke Murono, Sally Perreault, Steven Schrader, and Michael 
Shelby "An Occupational Reproductive Research Agenda for the Third Millennium" (2003) 111(4) Environmental Health Perspectives 584.

J Leibler, J Otte and E Silbergeld "Zoonotic disease risks and socioeconomic structure of industrial poultry production: review of the US experience with contract growing" (2008) Agriculture 1.

J Leigh “A History of Occupational Disease Recognition and Control” (2007) 23 J Occup Health and Safety - Aust NZ 6.

Sarah Linnstaedt, Kyle Riker, Cathleen Rueckeis, Katrina Kutchko, Lela Lackey, Kathleen McCarthy, Yi-Hsuan Tsai, Joel Parker, Michael Kurz, Phyllis Hendry, Christopher Lewandowski, Elizabeth Datner, Claire Pearson, Brian O'Neil, Robert Domeier, Sangeeta Kaushik, Alain Laederach and Samuel McLean "functional riboSNitch in the 3 'UTR of FKBP5 alters microRNA-320a binding efficiency and mediates vulnerability to chronic posttraumatic pain" (2018) 3458(17) Journal of Neuroscience 27.

Chris Llyod, Robert King and Lesly Chenoweth "Social Work, Stress and Burnout: A Review" (2002) 11(3) Journal of Mental Health 255.

Karen Lo and Felicity Lamm "Occupational Stress in the Hospitality Industry- An Employment Relations Perspective (2005) 30(1) NZJER 23.

Beverly Lorell and Blasé Carabello "Left ventricular hypertrophy: pathogenesis, detection and prognosis" (2000) 102 Circulation 470.

Mark Le Fevre and Gregory S Kolt "Occupational Stress: Are we talking about the same thing?" (2010) 35(2) NZJER 16.

Judith MacCormick, Kristine Dery and Darl Kolb "Engaged or just connected? Smart phones and employee engagement.” (2012) 41 Organisational Dynamics 194.

John Mackie "Causes and Conditions” (1965) 12 American Philosophical Quarterly 245.

Virginia Mantouvalou "Labour Law and Human Rights" (2016) 41(2) NZJER 3.

Virginia Mantouvalou “Are Labour Rights Human Rights?” (2012) 3 Eur Lab LJ 151.

G Mark and A Lyons "Māori healers' views on wellbeing: The importance of mind, body, spirit, family and land” (2010) 70(11) Social Science \& Medicine 1756.

Michael Marmot "Social justice, epidemiology and health inequalities (2017) 32(7) European Journal of Epidemiology 537. 
Micheal Marmot and Ruth Bell "Social inequality in health: A proper concern of epidemiology" (2016) 26(4) Annals of Epidemiology 238.

MG Marmot, G Davey Smith and S Stansfeld "Health inequalities among British civil servants: the Whitehall II study" (1991) 8754 Lancet 3371387.

$\mathrm{C}$ Martin and C Peterson "The social construction of chronicity- A key to understanding chronic care transformations" (2009) 15(3) J Eval Clin Pract 578.

C Maslach and M Leiter Early predictors of job burnout and engagement" (2008) 93 Journal of Applied Psychology 498.

C Mathers and D Loncar "Projections of global mortality and burden of disease from 2002 to 2030" (2006) 3(11) PLoS Medicine e442.

E A Mayer "The neurobiology of stress and gastrointestinal disease" (2000) 46(6) Gut 861. Richard Mayou, Laurence Kirmayer, Greg Simon, Kurt Kroenke and Michael Sharpe "Somatoform Disorders: Time for a New Approach in DSM-V" (2005) 162 Am J Psychiatry 847.

Nadine McDonnell "Commentary- Occupational Stress and Workers' Compensation: Getting out of the kitchen?” (2010) 35(2) NZJER 88.

B McEwen "Protective and damaging effects of stress mediators" (1998) 338 N Engl J Med 171.

Gerald McGwin "Causation in Epidemiology" (2010) Am Jrnl of Opthamology 599.

Shane Mc Inerney "Introducing the biopsychosocial model for good medicine and good doctors" (2002) 1537 BMJ 324.

David McLean, Neil Pearce, Christopher Walls and Richard Wigley "The 'Twin Study' and the misunderstanding on epidemiology that clouds occupational associations and low back disorder" (2011) 124 NZMJ 1338.

Peter McKenzie "The compensation scheme no one asked for: The origins of ACC in New Zealand" (2003) 34 VUW Law Rev 193.

L McWilliams, B Cox, M Enns "Mood and anxiety disorders associated with chronic pain: An examination in a nationally representative sample” (2003) 106 Pain 127.

M Meaney "Maternal care, gene expression and the transmission of individual differences in stress reactivity across generations" (2001) 24 Annual Review of Neuroscience 1162. 
Karen Messing and Jeanne Mager “Sex, gender and women's occupational health: The importance of considering mechanism" (2006) 101 (2) Environmental Research 149.

Thomas Münzel, Tommaso Gori, Wolfgang Babisch and Mathias Basner "Cardiovascular effects of environmental noise exposure” (2014) 35(13) Eur Heart J 829.

Dominique Musselman, Dwight Evans and Charles Nemeroff "The Relationship of Depression to Cardiovascular Disease: Epidemiology, Biology and Treatment” (1998) 55(7) Arch Gen Psychiatry 580.

E Muriwai, C Houkamau and C Sibley "Culture as cure? The protective function of Māori cultural efficacy on psychological distress" (2015) 44(2) New Zealand Journal of Psychology 14.

April Naturale "Secondary Traumatic Stress in Social Workers Responding to Disasters: Reports from the field" (2007) 35 Clin Soc Work J 173.

I Niedhammer, M Saurel-Cubizolles, M Piciotti and S Bonenfant S "How is sex considered in recent epidemiological publications on occupational risks?" (2000) 57(8) Occupational and Environmental Medicine 521.

I Niedhammer, JF Chastang, S David, L Barouhiel and G Barrandon "Psychosocial work environment and mental health: Jobstrain and effort-reward imbalance models in a context of major organizational changes" (2006) 12(2) Int J Occup Environ Health 111.

Melanie Nolan "Inequality of luck: Accident Compensation in New Zealand and Australia" (2013) 104 Labour History 189.

G Oakley "Frequency of human congenital malformations" (1986) 13(3) Clin Perinatol 545.

M O’Connor, L Litrell, C Fort, R Lane "Functional neuroanatomy of grief: An MRI study" (2003) 160 American Journal of Psychiatry 1946.

Joss Opie "The right to reasonably limited working hours in the smartphone era" (2016) 41(3) NZJER 24.

Geoffrey Palmer "The Future of Community Responsibility” (2004) 35 VUW Law Rev 905.

Lord Parker of Waddington "Compensation for Accidents on the Road: An Address" (1965) C L P 18. 
Gheorghe H Popescu, Irina Elana Petrescu and Oana Matilda Sabie "Algorithmic labour in the platform economy: Digital infrastructure, job quality and workplace surveillance" (2018) 13(3) Economics, Management and Financial Markets 74.

Kevin Purse and Robert Guthrie "Workers Compensation Policy in Australia: New Challenges for a New Government” (2008) JOALAP 99.

Kevin Purse "The evolution of workers' compensation policy in Australia" (2005) 14(1) Health Sociology Review 8.

Michael Quinlan “Organisational restructuring/downsizing, OHS regulation and worker health and wellbeing” (2007) 30(4) International Journal of Law and Psychiatry 385.

Michael Quinlan and Peter Sheldon "The enforcement of minimum labour standards in an era of neo-liberal globalisation: An overview" (2011) 22(2) ELRR 5.

M Quinlan and P Bohle "Overstretched and unreciprocated commitment: Reviewing research and policy debates on the OHS effects of downsizing and insecurity" (2009) 39(1) Int J Health Ser 1.

Katherine Ravenswood "Precarious work, vulnerable workers and the living wage" (2013) 38(2) NZJER 1.

Hartmut Rosa "Social acceleration: Ethical and political consequences of a desynchronized high-speed society (2003) 10(1) Constellations 3.

Lesley Rushton "The global burden of occupational diseases" (2017) 4 Curr Envir Health Rpt 340.

Wesley Salmon "Causality without counterfactuals" (1994) 61 Philosophy of Science 2 297.

Hans Selye "The general adaptation syndrome and the diseases of adaptation" (1946) $6 \mathrm{~J}$ Clin Endicronal Metab 117.

W Schaufeli, M Salanova, V Gonzalez-Roma and A Bakker "The measurement of engagement and burnout: A two sample confirmatory factor analytic approach" (2002) 3 Journal of Happiness Studies 71.

F Scheer, M Hilton, C Mantzoros and S Shea "Adverse metabolic and cardiovascular consequences of circadian misalignment” (2009) 106(11) Proc Natl Acad Sci U S A 4453. Emily Schindeler and Janet Ransley "Normalising and neutralising offending: The influence of health and safety regulation" (2015) 26(3) CICJ 305. 
K Scott, R Bruffaerts, A Tsung et al "Depression-anxiety relationships with chronic physical conditions: Results from world mental health surveys (2007) 103 Journal of affective disorders 113.

Jackie Leach Scully "What is a disease?" (2004) 5(7) Science and Society 650.

E Schernhammer, F Laden, F Speizer, W Willett, D Hunter and I Kawachi "Rotating night shifts and risk of breast cancer in women participating in the nurses' health study" (2001) 93(20) J Natl Cancer Inst 1563.

Peter Scweder, Michael Quinlan, Philip Bohle, Felicity Lamm and Andy Huat Bin Ang "Injury rates and psychological wellbeing in temporary work: A study of seasonal workers in the New Zealand food processing industry" (2015) 40(2) NZJER 24.

J Siegrist, D Starke, T Chandola, I Godin, M Marmot, I Niedhammer and R Peter "The measurement of effort-reward imbalance at work: European comparisons" (2004) 58(8) Soc Sci Med 1483.

Mitsuzo Shimoda "Soutsubyo ni tsuite" (1950) 21 Yonago igaku zasshi [Yonago Medical Journal] 3.

M Seligman, L Abramson, A Semmel and C von Baeyer "Depressive atributional style" (1979) 88 Jrnl Abnormal Psych 242.

Brian Shenal, David Harrison and Heath Demaree "The Neuropsychology of Depression: A Literature Review and Preliminary Model" (2003) 13(1) Neuropsychology Review 33. Paul Spoonley "Is non-standard work becoming standard? Trends and issues" (2004) 29(3) NZJER 3.

B Springer, U Orendi, P Much, G Hoger, W Ruppitsch, K Krziwanek, S Metz-Gercek and H Mittermayer "Methicillin-resistant Staphylococcus aureus: a new zoonotic agent?" (2009) Wien Klin Wochenscher 121.

Magdalena Stadin, Maria Nordin, Anders Brostrom, Linda Hanson Magnusson, and Hugo Westerlund "P091Information and communication technology stress at work and development of suboptimal self-rated health" (2016) 73 Occupational and Environmental Medicine A150.

Robert Story "Social assistance or a worker's right: Workmen's compensation and the struggle of injured workers in Ontario, 1970-1985" (2006) Studies in Political Economy 78. 
S Stranges, FP Cappuccio and NB Kandala "Cross-sectional versus prospective associations of sleep duration with changes in relative weight and body fat distribution: the Whitehall II Study" (2008) 167(3) Am J Epidemiol 321.

Nicola Swain and Matthew Johnson "Chronic pain in New Zealand: A community sample" (2014) 127(1388) NZMJ 1.

$\mathrm{N}$ Tang, C Goodchild and A Sanborn et al "Deciphering the temporal link between pain and sleep in a heterogeneous chronic pain patient sample: A multilevel daily process study (2010) 35 Sleep 675.

Julio Tolentino and Sergio Schmidt "DSM-5 criteria and depression severity: Implications for clinical practice" (2018) 9 Front Psychology 450.

A Tsang, M Von Korff, S Lee et al. "Common chronic pain conditions in developed and developing countries: Gender and age differences and comorbidity with depression-anxiety disorders" (2008) 9 The Journal of Pain 883.

Elsa Underhill, Michael Quinlan "How precarious employment affects health and safety at work: The case of temporary agency workers" (2011) 66(3) Relations Industrielles 397. Ari Väänänen, Michael Murray and Anna Kuokkanen "The growth and stagnation of work stress: Publication trends and scientific representations 1960-2011" (2014) 27(4) History of the Human Sciences 116.

Jos Verbeek "When work is related to disease, what establishes evidence for a causal relation?" (2012) 3(2) Saf Health Work 110.

AN Vgontzas, EO Bixler, GP Chrousos "Sleep apnea is a manifestation of the metabolic syndrome" (2005) 9 Sleep Med Rev 211.

AN Vgontzas, E Zoumakis and EO Bixler "Adverse effects of modest sleep restriction on sleepiness, performance, and inflammatory cytokines" (2004) 89(5) J Clin Endocrinol Metab 2119.

T Vrijkotte, L van Doornen, E de Geus "Effects of work stress on ambulatory blood pressure, heart rate, and heart rate variability" (2000) 35 Hypertension 880.

J Wajcman and E Rose "Constant connectivity: Rethinking interruptions at work" (2011) 32 Organisation Studies 941.

David Walters "Worker representation and psycho-social risks: A problematic relationship?" (2011) 49 Safety Science 599. 
JianLi Wang, Elizabeth Smailes, Jitender Sareen, Norbert Schmitz, Gordon Fick and Scott Patten "Three job-related stress models and depression: a population-based study" (2012) 47 Soc Psychiatry Psychiatr Epidemiol 185.

JL Wang "Perceived work stress and major depressive episode(s) in a population of employed Canadians over 18 years old" (2004) 192(2) J Nerv Ment Dis 160.

JL Wang "Work stress as a risk factor for major depressive episode(s)" (2005) 35(6) Psychol Med 865.

JL Wang, TO Affifi and B Cox B "The relationship between work-home imbalance and mental disorders: findings from the US. National Comorbidity Survey" (2007) 50(2) Am J Ind Med 143.

JL Wang, N Schmitz, CS Dewa, SA Stansfeld "Changes in perceived job strain and risk of major depression: results from a population-based longitudinal study" (2009) 169(9) Am J Epidemiol 1085.

Juliet Webster "Micro workers and the Gig Economy: Separate and Precarious (2016) 23 NLF 56.

Lord Wedderburn “Labour Law: From Here to Autonomy?” (1987) 16 ILJ 1.

N Wege, N Dragano, R Erbel, KH Jockel, S Moebus, A Stang and J Siegrist "When does work stress hurt? Testing the interaction with socioeconomic position in the Heinz Nixdorf Recall Study" (2008) 62(4) J Epidemiol Commun Health 338.

AC Williams and KD Craig "Updating the definition of pain" (2016) 157(11) Pain 2420.

Margaret Wilson "Precarious work-New Zealand experience" (2014) 39(2) NZJER 22.

Alex J Wood, Mark Graham, Vili Lehdonvirta and Isis Hjorth "Good gig, bad gig:

Autonomy and algorithmic control in the global gig economy" (2019) 33(1) Work, Employment and Society 56.

Owen Woodhouse "Aspects of the Accident Compensation Scheme" [1979] NZLJ 395.

John Wren “A Contested Workplace: Situating New Zealand's OHSM Regulatory Practice within the Literature -an Introduction to the Policy, History and Regulatory Debates" (2008) 33(2) NZJER 45.

Xiaoyuan Wu, Daya Yang, Wendong Fan, Chunyue Fan and Guifu Wu "Cardiovascular Risk Factors in Noise-Exposed Workers in China: Small Area Study" (2017) 19(91) Noise Health 245. 
M Wulf and A Voss “MRSA in livestock animals-an epidemic waiting to happen?” (2008) 14 Clin Microbiol Infect 6.

HK Yaggi, AB Araujo, JB McKinlay "Sleep duration as a risk factor for the development of type 2 diabetes" (2006) 29(3) Diabetes Care 657.

T Yokohama and S Iida "Utsubyo no seishin ryoho" [Psychotherapy for depression] (1998) 13 Seishinka chiryogaku [Journal of psychiatric treatment] 87.

S Yusuf, S Hawken and S Ounpuu "Effect of potentially modifiable risk factors associated with myocardial infarction in 52 countries (the INTERHEART study): case-control study" (2004) 9438 Lancet 937.

Kezhong Zhang "Environmental stressor, stress response, and disease" (2018) 3(1) Environmental Disease 1.

\section{Parliamentary and Government Materials}

(18 September 1964) 340 NZPD 2292 (Workers' Compensation Amendment Bill- Tom Shand).

(3 October 1972) 381 NZPD 2983 (Accident Compensation Bill- David Thomson).

(3 October 1972) 381 NZPD 2985 (Accident Compensation Bill- Dr Finlay).

(3 October 1972) 381 NZPD 2985 (Accident Compensation Bill- David Thomson).

(3 October 1972) 381 NZPD 2994 (Accident Compensation Bill - Dr Gerard Wall).

(3 October 1972) 381 NZPD 3023 (Accident Compensation Bill- Arthur Faulkner).

Department of Labour Guideline Healthy Work: Managing Stress and Fatigue in the Workplace (June 2003).

Safe Work Australia Explanatory Memorandum- Model Work Health and Safety Bill Environmental Protection Authority (NZ) Thresholds and Classifications under the Hazardous Substances and New Organisms Act 1996 (January 2012).

\section{Reports}

Acclaim Otago (Inc) Adopting issues: An interim report to the United Nations Committee on the Convention on the Rights of Persons with Disabilities (February, 2014). 
Acclaim Otago (Inc) Understanding the Problem: An analysis of ACC appeals processes to identify barriers to access to justice for injured New Zealanders (July, 2015).

Allen and Clarke National Occupational Health and Safety Advisory Committee Technical Report to Government No 11 Defining Work-Related Harm: Implications for Diagnosis, Rehabilitation, Compensation and Prevention (NOHSAC, 2009).

J Biddle Lumbar Disc Pathology: Medical Council Special Report No 1 (HMSO, London, 1930).

Tim Bentley, Bevan Catley, Helena Cooper-Thomas, Dianne Gardner, Michael O'Driscoll and Linda Trenberth Understanding Stress and Bullying in New Zealand Workplaces: Final Report to the OH\&S Steering Committee (December 2009).

Tim Bentley, Laurie McLeod and Stephen Teo The state of the tertiary education sector in New Zealand - 2013 (TEU, Wellington. 2013)

See S Bevan T Quadrello, R McGee, M Mahdon, A Vavrovsky and L Barham "Fit for work? Musculoskeletal disorders in the European workforce" (The Work Foundation, 2009).

William Beveridge Social Insurance and Allied Services Report by Sir William Beveridge (MNSO, London, 1942).

William Birch Accident Compensation: A Fairer Scheme (Government Printer, Wellington, 1991).

Philip Bohle, John Buchanan, Tony Cooke, Gillian Considine, Michelle Jakubauskas, Michael Quinlan, Michael Rafferty and Rose Ryan The Evolving Workplace Environment in New Zealand: Implications for Occupational Health and Safety (NOHSAC Technical Report 10) (NOHSAC, Wellington, 2008).

Kate Bryson and Anne Duncan Mental Health in the Construction Industry Scoping Study (BRANZ, 2018).

Nick Carrol New Zealand Treasury Report: Structural Change in the New Zealand Economy 1974-2012 (New Zealand Treasury, Wellington, 2012).

Committee on Absolute Liability Report of the Committee on Absolute Liability for Motor Vehicle Accidents (Government Printer, Wellington, 1963).

Commonwealth of Australia National Review into Model Occupational Health and Safety Laws: First Report to the Workplace Relations Ministers' Council (October 2008) 
Miriam Dean Independent Review of the Acclaim Otago (Inc) July 2015 Report in to Accident Compensation disputes processes (May 2016).

Department of Labour Occupational Health Action Plan to 2013: Workplace Health and Safety Strategy for New Zealand to 2015 (December 2011).

Tim Driscoll, Evan Dryson, Anne-Marie Feyer, Philippa Gander, Selwyn McCracken, Neil Pearce and Mark Wagstaffe Review of Schedule 2 of the Injury Prevention Rehabilitation and Compensation Act 2001 (IPRC Act) (NOHSAC, Wellington, 2005).

Tim Driscoll, Andrea 'TMannatje, Evan Dryson, Ane-Marie Feyer, Philippa Gander, Selwyn McCracken, Neil Pearce and Mark Wagstaffe NOHSAC Technical Report: The Burdon of Occupational Disease and Injury in New Zealand (NOHSAC, Wellington, 2004).

Warren Forster, Tom Barraclough and Tiho Maijatov Solving the problem: Causation, transparency and access to justice in New Zealand's personal injury system (May 2017).

Government Inquiry in to Mental Health and Addiction He Ara Oranga: Report of the Government Inquiry in to Mental Health and Addiction (Wellington, NZ Government, 2018).

Samuel Harvey, Sadhbh Joyce, Leona Tan, Anya Johnson, Helena Nguyen, Matthew Modini and Markus Groth Developing a mentally healthy workplace: A review of the literature: A report for the National Mental Health Commission and Mentally Healthy Workplace Alliance (November 2014).

IHME GBD 2010 Change in leading causes and risks between 1990 and 2010 (IHME, 2013).

Independent Taskforce on Workplace Health and Safety The Report of the Independent Taskforce on Workplace Health and Safety: He Korowai Whakaruruhau (April 2013).

Mauri Ora Associates Maori Experience of ACC: Final Report to the Department of Labour (Maori Ora Associates, 2010).

Petra Mueller, Nikki Kells and Donald Campbell Ministry of Primary Industries Risk Profile: The emergence of campylobacter jejuni ST 6964 in poultry in New Zealand and its associated antimicrobial resistance Technical Paper No 2016/16 (Ministry of Primary Industries, Wellington, 2016). 
William Meredith Final Report on the Liability of Employers to make Compensation to their Employees for Injuries Received in the Course of their Employment which are in Force in other Countries, and as to How Far Such Laws are found to Work Satisfactorily (Government Printer, Toronto, 1913).

Ministry of Business, Innovation and Employment New Zealand Sectors Report 2014: An Analysis of the New Zealand Economy by Sector (April 2014).

Ministry of Business, Innovation and Employment (MBIE) Working Safer: Blueprint for New Zealand's Health and Safety System (August 2013).

Ministry of Business, Innovation and Employment (MBIE) Working Safer: Reducing Work-Related Fatalities and Serious Injury by 2020: Progress Toward the Target (March 2015).

National Institute of Occupational Safety and Health The changing organisation of work and the safety and health of working people: Knowledge gaps and research directions (Cincinnati, US Department of Health and Human Services, 2002).

National Occupational Health and Safety Commission National Occupational Health and Safety Commission Annual Report 2002-2003 (Canberra, NOSHC, 2003).

New Zealand Council of Trade Unions The Dupes of Hazard: A Critical Review of the Health and Safety Act 1992 in Practice (NZCTU, Wellington,1994).

New Zealand Federation of Labour 31 $1^{\text {st }}$ Annual Conference Report (Wellington Standard Press 1968).

New Zealand Law Commission Accident Compensation Scheme: Interim Report on Aspects of Funding (New Zealand Law Commission, Wellington, 1987).

New Zealand Law Commission Personal Injury Prevention and Recovery: Report on the Accident Compensation Scheme (Wellington, Law Commission, 1988).

New Zealand Officials Committee Review of the Officials Committee of the Accident Compensation Scheme (NZ Government, Wellington, 1986).

New Zealand Royal Commission on Social Policy April Report: Report of the Royal Commission on Social Policy (Government Printer, Wellington, 1988).

New Zealand Tax Working Group The future of work: Sustaining the tax system (IRD and Treasury, April 2018).

OECD Mental Health at Work New Zealand (2018, OECD Publishing, Paris). 
Geoff Plimmer, Jessie Wilson, Jane Bryson, Stephen Blumenfeld, Noelle Donnelly and Bill Ryan Workplace Dynamics in New Zealand Public Services (Public Service Association, Wellington, 2013).

Alfred Robens (Chair) Report of the Committee on Safety and Health at Work (HMSO, London, 1972).

Gerry Rodgers “Labour Market Flexibility and Decent Work” DESA UN Working Paper No 47 (July 2007).

Yves Roquelaure Report 142: Musculoskeletal disorder and psychosocial factors at work (European Trade Union Institute, Brussels, 2018).

Royal Commission on the Pike River Coal Mine Tragedy Report of the Royal Commission on the Pike River Coal Mine Tragedy (October 2012).

Royal Commission of Inquiry into Personal Injury in New Zealand Compensation for Personal Injury in New Zealand: Report of the Royal Commission of Inquiry (Government Printer, Wellington, 1967).

SafeWork Australia, The Incidence of Accepted Workers' Compensation Claims for Mental Stress in Australia (April 2013).

SafeWork Australia Work-Related Mental Disorders Profile 2015 (SafeWork Australia, 2016).

E Schneider and X Irastorza "OSH in figures: Work-related musculoskeletal disorders in the EU- Facts and figures" for the European agency for health and safety at work (2010). Statistics New Zealand Women at Work: 1991-2013 (October 2015).

Andrea 'T mannetje, Tania Slater, David Mclean, Amanda Eng, Celia Briar, Jeroen Douwes NOSHAC Technical Report 13: Women's Occupational Health and Safety in New Zealand (NOHSAC, Wellington, 2009).

Cushla Thomson, Susan Begg and Bryce Wilkinson Accident Compensation: Options for Reform (Credit Suisse First Boston and New Zealand Business Roundtable, Wellington, 1998).

United Nations Department of Economic and Social Affairs Disability and Development Report 2018 (United Nations, New York, 2019).

Leonie Walker NZNO employment survey 2017, Our nursing workforce: resilience in adversity (New Zealand Nurses Organisation, Wellington, 2017). 
Owen Woodhouse; National Rehabilitation and Compensation Scheme Committee of Inquiry Report of the Committee of Inquiry into Compensation and Rehabilitation in Australia (Government Printer, Canberra, 1976).

\section{Dissertations}

Murdo MacMillan “Accident Compensation in New Zealand: A Study of Change 19791982" Submitted for the degree Diploma of Industrial Relations (Victoria University Thesis Repository, 1983).

\section{Internet Resources}

ACC, ACC1174: How to Manage Hazards: For Construction (June 2013).

ASMS press release for nature of claims being made NZRDA "Doctors Denied Safer Hours" (18 August 2016) <http://www.asms.org.nz/news/other-news/2016/08/18/doctorsdenied-safer-hours/>

Brian Easton "The Foundations of Social Welfare in New Zealand" (Sept 2017) $<$ https://www.eastonbh.ac.nz/2011/02/the-foundations-of-social-welfare-in-newzealand/>

Eurofound First findings: Sixth European working conditions survey (2015) $<$ http://www.eurofound.europa.eu/publications/resume/2015/working-conditions/firstfindings-sixth-european-working-conditions-survey-resume $>$ Harvard Medical School "Understanding the stress response: Chronic activation of this survival mechanism impairs health" (18 March 2016) Harvard Health Publishing $<$ https:/www.health.harvard.edu/staying-healthy/understanding-the-stress-response $>$ International Association for the Study of Pain "Part III: Pain terms, a current list with definition and notes on usage 1194" (2018) <http://www.iasppain.org/Eduation/Content.aspx> Japan External Trade Organisation website "Section 4.5 Legislation on working hours, breaks and days off” at: <www.jetro.go.jp/en/invest/setting_up/section4/page5.html> 
Sarah Linnstaedt "Chronic pain after trauma may depend on what stress gene variation you carry" (28 August 2018) The Conversation <https://theconversation.com/chronicpain-after-trauma-may-depend-on-what-stress-gene-variation-you-carry-102021> Ministry of Health, Labour and Welfare (Japan) Annual Health, Labour and Welfare Report 2016, <http://www.mhlw.go.jp/english/wp/wp-hw10/index.html> Ministry of Health New Zealand Burden of Diseases, Injuries and Risk Factors Study New Zealand Ministry of Health website <https://www.health.govt.nz/nz-healthstatistics/health-statistics-and-data-sets/new-zealand-burden-diseases-injuries-and-riskfactors-study>

Lorimer Moseley Explainer: what is pain and what is happening when we feel it? (19 November 2015) The Conversation <http://theconversation.com/explainer-what-is-painand-what-is-happening-when-we-feel-it-49040>

Office for National Statistics (UK) "Sickness absence in the labour market" (2012) available on the Office for National Statistics website $<$ https://www.ons.gov.uk/> Proskaur Rose "Japan's labor reform caps overtime in bid to curb karoshi” Lexology (10 December 2018) <www.lexology.com/library/detail.aspx?g=36324f78-5923-490b-88516757457883f4>

Guy Standing “The Precariat: Today's Transformative Class?” Great Transition Initiative (October 2018) <https://greattransition.org/publication/precariat-transformative-class $>$ EWK Rosenquist, MD Aronson and M Crowley "Definition and pathogenesis of chronic pain" (2017) on Uptodate.com (online medical resource) <https://www.uptodate.com> SafeWork Australia “International Women's Day: Reflecting on women's health and safety in the workplace" (March 2016)

$<$ http://www.safeworkaustralia.gov.au/sites/swa/news/pages/tn09072016>

Klaus Schwab, Chairman of World Economic Forum "The Fourth Industrial Revolution:

What it means, how to respond" (14 January 2016) published on the World Economic Forum Website $<$ https://www.weforum.org/agenda/2016/01/the-fourth-industrialrevolution-what-it-means-and-how-to-respond/>

WorkSafe New Zealand Bullying at Work: Advice for Workers (WorkSafe NZ, Wellington, 2017) <http://www.worksafe.govt.nz/the-toolshed/tools/bullying-preventiontoolbox/\#page=15> 
WorkSafe New Zealand Guides for the construction industry, (June 2019) $<$ http://construction.worksafe.govt.nz/guides/>

\section{Speeches}

Geoffrey Palmer "A retrospective on the Woodhouse Report: The vision, the performance, and the future" Sir Owen Woodhouse Memorial Lecture, Victoria University of Wellington (September 2018)

Ted Thomas "Tribute to Sir Owen Woodhouse" speech given at Accident Compensation: Forty Years on - a Celebration of the Woodhouse Report: "Compensation for Personal Injury in New Zealand. Report of the Royal Commission of Inquiry", University of Auckland (13 December 2007).

\section{Media Reports}

Cate Broughton "OECD report calls for extension of ACC" (13 Dec 2018)

$<$ www.stuff.co.nz/national/health/109313061/oecd-report-calls-for-extension-to-acc> Shabnam Dastgheib "Auckland health workers begin strike action" (10 Nov 2015) Stuff $<$ http://www.stuff.co.nz/auckland/73859230/Auckland-health-workers-begin-strikeaction>

Isobel Ewing "Overworked Doctors Making Mistakes with Patients - Survey" (17 August 2016) <http://www.newshub.co.nz/politics/overworked-doctors-making-mistakes-withpatients---survey-2016081716> Kyodo "Nagoya court rules Toyota employee died from overwork" Japan Times (1 Dec 2007) available at: <www.japantimes.co.jp/news/2007/12/01/national/nagoya-court-rulestoyota-employee-died-from-overwork/\#.XNC-EegzaUk>

Thomas Manch "New Zealand's 'working poor' and the push to understand how many are struggling" (16 May 2018) Stuff <https://www.stuff.co.nz/national/103761074/newzealands-working-poor-and-the-push-to-understand-how-many-are-struggling $>$

Tania Page "The working poor: In a job, but unable to make ends meet" (1 July 2018) TVNZ <https://www.tvnz.co.nz/one-news/new-zealand/working-poor-in-job-but-unablemake-ends-meet> 
Emma Seppälä and Julie Moeller "1 in 5 employees highly engaged and at risk of burnout" in Harvard Business Review online (16 May 2018) <https://hbr.org/2018/02/1-in-5-highlyengaged-employees-is-at-risk-of-burnout>

Stuff (no author) "New Zealand's underemployed: Working, but not enough" (25 June 2018) Stuff $<$ https://www.stuff.co.nz/business/105001410/new-zealands-underemployedworking-but-not-enough?utm_source $=$ The + Bulletin\&utm_campaign=81430e5452-> Chris Weller "A 31-year-old's 'death from overwork' causes Japan to rethink work-life balance" (6 October 2017) <www.businessinsider.com.au/japan-womans-death-fromoverwork-government-rethinks-work-2017-10?r=US\&IR=T>

(no author) “Japan vows to stamp out 'death by overwork' while building 2020 Tokyo Olympics stadium" (13 October 2017) at <www.rt.com/sport/406583-japan-olympicsoverwork-death-suicide/>

(no author) "Toyota widow compensated for work suicide" Japan Times (9 July 3003).

\section{Other}

Nadine McDonnell “New Zealand's Workers' Compensation: How will it fare in a changing environment?" paper presented to the 2008 New Zealand Labour, Employment and Work Conference at Victoria University of Wellington.

Anna Milanez "The taxation of non-standard work" Presentation (OECD, November 2018).

J Moeller, Z Ivcevic, A E White, V Menges and M A Brackett "Highly engaged but burnt-out: Intra-individual profiles in the US Workforce (2018) OSF Preprints online.

$\mathrm{R}$ Wellins, $\mathrm{P}$ Berthal and M Phelps Employee engagement: The key to realising competitive advantage (Development Dimensions International, Online, 2005).

WHO Preamble to the Constitution of the World Health Organization (WHO, New York, 1946).

WHO "Occupational exposures to vibration for hand held tools (Protecting Workers Series 10)" $<$ https://www.who.int/occupational_health/pwh_guidance_no.10_teaching_materials .pdf $>$ 